\title{
Cyanobacterial toxins
}

\section{CONTENTS}

Introduction and general considerations 15

References 19

2.1 Hepatotoxic cyclic peptides - microcystins and nodularins 21

2.1.1 Chemical structures 21

2.1.2 Toxicity: mode of action 24

2.1.3 Derivation of provisional guideline values 25

2.1.4 Production 28

2.1.4.1 Producing cyanobacteria 28

2.1.4.2 Microcystin/nodularin profiles 31

2.1.4.3 Biosynthesis 32

2.1.4.4 Regulation of biosynthesis 32

2.1.5 Occurrence in water environments 35

2.1.5.1 Bioaccumulation 36

2.1.6 Environmental fate 36

2.1.6.1 Partitioning between cells and water $\quad 36$

2.1.6.2 Chemical breakdown 37

2.1.6.3 Biodegradation 38

References 39

2.2 Cylindrospermopsins 53

2.2.1 Chemical structures 53

2.2.2 Toxicity: mode of action 53

2.2.3 Derivation of provisional guideline values 54

2.2.4 Production 57

2.2.4.1 Producing cyanobacteria 57

2.2.4.2 Cylindrospermopsin profiles $\quad 58$

2.2.4.3 Biosynthesis 58

2.2.4.4 Regulation of biosynthesis $\quad 59$

2.2.5 Occurrence in water environments 61

2.2.5.1 Bioaccumulation 62

2.2.6 Environmental fate $\quad 62$

2.2.6.1 Partitioning between cells and water $\quad 62$ 
2.2.6.2 Chemical breakdown $\quad 62$

2.2.6.3 Biodegradation 63

References 64

2.3 Anatoxin-a and analogues $\quad 72$

2.3.1 Chemical structures $\quad 72$

2.3.2 Toxicity: mode of action 73

2.3.3 Derivation of health- based reference values $\quad 73$

2.3.4 Production $\quad 76$

2.3.4.1 Producing cyanobacteria 76

2.3.4.2 Toxin profiles $\quad 76$

2.3.4.3 Biosynthesis and regulation $\quad 81$

2.3.5 Occurrence in water environments $\quad 82$

2.3.5.1 Bioaccumulation 84

2.3.6 Environmental fate $\quad 84$

2.3.6.1 Partitioning between cells and water 84

2.3.6.2 Chemical breakdown $\quad 85$

2.3.6.3 Biodegradation $\quad 85$

References $\quad 86$

2.4 Saxitoxins or Paralytic Shellfish Poisons 94

2.4.1 Chemical structures $\quad 94$

2.4.2 Toxicity: mode of action 95

2.4.3 Derivation of guideline values $\quad 97$

2.4.4 Production 100

2.4.4.1 Producing cyanobacteria 100

2.4.4.2 Toxin profiles 100

2.4.4.3 Biosynthesis and regulation 101

$\begin{array}{ll}\text { 2.4.5 Occurrence in water environments } & 102\end{array}$

2.4.5.1 Bioaccumulation 103

2.4.6 Environmental fate 104

References 104

2.5 Anatoxin-a(S) 109

2.5.1 Chemical structure 109

2.5.2 Toxicity: mode of action 109

2.5.3 Derivation of guideline values for
anatoxin-a $(\mathrm{S})$ in water

2.5.4 Production, occurrence and environmental fate $\quad 110$

References 111

2.6 Marine dermatotoxins 113

2.6.1 Chemical structures $\quad 114$

2.6.2 Toxicity 115

2.6.3 Incidents of human injury through marine cyanobacterial dermatotoxins 116

2.6.4 Biosynthesis and occurrence in the environment 118

References 
$2.7 \beta$-Methylamino-L-alanine (BMAA)

2.7.1 Discrepancies introduced by incorrect BMAA analysis

2.7.2 The BMAA-human neurodegenerative disease hypothesis

2.7.2.1 ALS/PDC attributed to BMAA versus other manifestations of neurodegenerative disease

2.7.3 Postulated human exposure and BMAA mechanism of action

2.7.4 Conclusions

2.8 Cyanobacterial lipopolysaccharides (LPS) 137

2.8.1 General characteristics of bacterial LPS 137

2.8.2 What is known about bioactivity of cyanobacterial LPS?

2.8.3 Methodological problems of studies on cyanobacterial LPS

2.8.4 Possible exposure routes to cyanobacterial LPS 143

2.8.5 Conclusions 144

References 145

2.9 Cyanobacterial taste and odour compounds in water 149

2.9.1 Chemistry and toxicity 149

2.9.2 Analysis 150

2.9.3 Producing organisms 151

2.9.4 Biosynthesis 152

2.9.5 Geosmin and MIB concentrations in 152 aquatic environments 152

2.9.6 Removal of geosmin and MIB by water treatment
processes

2.9.7 Co-occurrence of T\&O compounds and cyanotoxins 153

References 154

2.10 Unspecified toxicity and other cyanobacterial metabolites 156

2.10.1 Bioactive metabolites produced by cyanobacteria $\quad 156$

2.10.2 Toxicity of cyanobacteria beyond known cyanotoxins $\quad 158$

References

\section{INTRODUCTION AND GENERAL CONSIDERATIONS}

The following sections provide an overview of the individual types of cyanobacterial toxins, focusing on toxins that have been confirmed to, or suggested to have implications for human health, namely, microcystins, cylindrospermopsins, anatoxins, saxitoxins, anatoxin-a(S) and dermatotoxins, the latter primarily produced by marine cyanobacteria. Two further cyanobacterial metabolites, lipopolysaccharides (LPS) and $\beta$-methylamino-alanine (BMAA), are discussed in respective sections with 
the conclusion that the available evidence does not show their proposed toxic effects to occur in dose ranges relevant to the concentrations found in cyanobacterial blooms. A further section includes information on taste and odour compounds produced by cyanobacteria because, while actually not toxic, they sometimes indicate the presence of cyanobacteria. Finally, recognising that there are many cyanobacterial metabolites and further toxic effects of cyanobacterial cells that have been observed which cannot be attributed to any of the known cyanotoxins, a section covers "additional toxicity" and bioactive cyanobacterial metabolites.

The sections on the major toxin types review the chemistry, toxicology and mode of action, producing cyanobacteria and biosynthesis, occurrence and environmental fate. Given the document's scope, the individual sections discuss ecotoxicological data only briefly. This, however, does not imply that cyanotoxins do not play an important role in aquatic ecosystems. Further, possible benefits of toxin biosynthesis for the producing cyanobacteria are currently discussed but not yet understood, and this remains an important field of research but is discussed in this volume only briefly.

For microcystins, cylindrospermopsins and saxitoxins guideline values (GVs) have been derived based on the toxicological data available and considering there is credible evidence of their occurrence in water to which people may be exposed. For anatoxin-a, although GVs cannot be derived due to inadequate data, a "bounding value", or health-based reference value, has been derived. For anatoxin-a(S) and the dermatotoxins, the toxicological data for deriving such values are not sufficient, and hence, no such values are proposed.

\section{BOX 2.I: HOW ARE GUIDELINE VALUES DERIVED?}

For most chemicals that may occur in water, including for the known cyanotoxins, it is assumed that no adverse effect will occur below a threshold dose. For these chemicals, a tolerable daily intake (TDI) can be derived. TDIs represent an estimate of an amount of a substance, expressed on a body weight basis, that can be ingested daily over a lifetime without appreciable health risk. TDIs are usually based on animal studies because, for most chemicals, the available epidemiological data are not sufficiently robust, mainly because the dose to which people were exposed is poorly quantified and because it is scarcely possible to exclude all confounding factors (including simultaneous exposure to other substances) that may have influenced differences between those exposed and the control group. TDIs based on animal studies are based on long-term exposure, preferably spanning a whole life cycle or at least a major part of it, exposing groups of animals (frequently mice or rats) to a series of defined doses applied orally via drinking-water or 
gavage. The highest dose for which no adverse effects in the exposed animals were detected is the no observed adverse effect level (NOAEL), generally expressed in dose per body weight and per day (e.g., $40 \mu \mathrm{g} / \mathrm{kg}$ bw per day). Sometimes no NOAEL is available, while the lowest observed adverse effect level (LOAEL) can be considered in establishing the TDI. The LOAEL is defined as the lowest dose in a series of doses causing adverse effects. An alternative approach for the derivation of a TDI is the determination of a benchmark dose (BMD), in particular, the lower confidence limit of the benchmark dose (BMDL; WHO, 2009a). A BMDL can be higher or lower than NOAEL for individual studies (Davis et al., 20II).

A NOAEL (or LOAEL or BMDL) obtained from animal studies cannot be directly applied to determine "safe" levels in humans for several reasons such as differences in susceptibility between species (i.e., humans vs. mice or rats), variability between individuals, limited exposure times in the experiments or specific uncertainties in the toxicological data. For example, for the cyanotoxins for which WHO has established GVs, exposure times did not span a whole life cycle because the amount of pure toxin needed for such a long study - a few hundred grams - was simply not available or would be extremely costly to purchase. To account for these uncertainties, a NOAEL is divided by uncertainty factors (UFs). The total UF generally comprises two 10 -fold factors, one for interspecies differences and one for interindividual variability in humans. Further uncertainty factors may be incorporated to allow for database deficiencies (e.g., less than lifetime exposure of the animals in the assay, use of a LOAEL rather than a NOAEL, or for incomplete assessment of particular endpoints such as lack of data on reproduction) and for the severity or irreversibility of effects (e.g., for uncertainty regarding carcinogenicity or tumour promotion). Where adequate data is available, chemical specific adjustment factors (CSAFs) can be used for interspecies and intraspecies extrapolations, rather than the use of the default UFs.

The TDI is calculated using the following formula:

$$
\mathrm{TDI}=\frac{\mathrm{NOAEL} \text { or LOAEL or BMDL }}{\mathrm{UF}_{1} \times \mathrm{UF}_{2} \times \mathrm{UF}_{\mathrm{N}} \text { or CSAFs }}
$$

The unit of TDI generally is the amount of toxin per bodyweight (bw) per day, for example, $0.1 \mu g / k g$ bw per day.

To translate the TDI to a GV, the following formula is generally used:

$$
\mathrm{GV}=\frac{\mathrm{TDI} \times \mathrm{bw} \times P}{C}
$$


For drinking-water GVs, WHO uses a daily water consumption $(C)$ of $2 \mathrm{~L}$ and a bodyweight of an adult person of $60 \mathrm{~kg}$ as default values, while emphasising that this may be adapted to regional or local circumstances. The fraction of exposure assumed to occur through drinking-water ( $P$; sometimes termed allocation factor) is applied to account for the share of the TDI allocated to a specific exposure route. The default $P$ for drinking-water is $0.2(20 \%)$. Where there is clear evidence that drinking-water is the main source of exposure, like in the case of cyanotoxins, $P$ has been adjusted to 0.8 , which still allows for some exposure from other sources, including food. Again, this can and should be adapted if local circumstances propose a different factor to be more appropriate. The unit of a GV is a concentration, for example, $0.8 \mu \mathrm{g} / \mathrm{L}$.

GVs for drinking-water (using a TDI) are generally derived to be safe for lifetime exposure. This means that briefly exceeding a lifetime $\mathbf{G V}$ doesn't pose an immediate risk or imply that the water is unsafe. This should be communicated accordingly and is particularly relevant where elevated cyanotoxin concentrations occur only during brief seasonal blooms. To clarify this, WHO has derived GVs for short-term exposure for microcystins and cylindrospermopsins. To differentiate these two GVs for cyanotoxins, these have been designated $\mathbf{G V}_{\text {chronic }}$ and $\mathbf{G V}_{\text {short-term }}$. In consequence, a concentration in drinking-water that exceeds the $\mathrm{GV}_{\text {chronic }}$ up to a concentration of $\mathrm{GV}_{\text {short-term }}$ does not require the immediate provision of alternative drinking-water - but it does require immediate action to prevent cyanotoxins from further entering the drinking-water supply system and/or to ensure their efficient removal through improving the drinking-water production process. The $\mathrm{GV}_{\text {short-term }}$ provides an indication on how much the $\mathrm{GV}_{\text {chronic }}$ can be exceeded for short periods of about 2 weeks until measures have been implemented to reduce the cyanotoxin concentration. Derivation of $\mathrm{GV}_{\text {short-term }}$ follows a similar approach to development of the traditional GVs. The short-term applicability of these values, however, may result in a different study selected for the identification of the NOAEL or LOAEL (particularly if the $\mathrm{GV}_{\text {chronic }}$ was based on long-term exposure) and the uncertainty factors (UFs) applied, particularly the UF for related database deficiencies.

For recreational exposure, the corresponding GV proposed $\left(\mathbf{G V}_{\text {recreation }}\right)$ takes into account the higher total exposure of children due to their increased likelihood of longer playtime in recreational water environments and accidental ingestion. The default bodyweight of a child and the volume of water unintentionally swallowed are $15 \mathrm{~kg}$ and $250 \mathrm{~mL}$, respectively (WHO, 2003), and these are used to calculate the $\mathrm{GV}_{\text {recreation. }}$. The same NOAEL or LOAEL and UFs applied for the $\mathrm{GV}_{\text {short-term }}$ are used to calculate the $\mathrm{GV}_{\text {recreation }}$. 
All GVs proposed by WHO may be subject to change when new toxicological data become available. By default, GVs with high uncertainty (UF $\geq 1000$ ) are designated as provisional by WHO. GVs with high uncertainty are more likely to be modified as new information becomes available. Also, a high uncertainty factor indicates that new toxicological data are likely to lead to a higher rather than a lower GV, and thus, the provisional GV is likely a conservative one; that is, it presumably errs on the safe side.

Several national and regional GVs or standards deviate from the values proposed by $\mathrm{WHO}$, due to different assumptions on body weight, estimated water intakes or allocation factors in consequence of specific exposure patterns in certain areas or for specific population groups (and sometimes also due to divergent interpretations of toxicological data). WHO gives guidance on adapting WHO GVs to country contexts in the document, "Developing Drinking-water Quality Regulations and Standards" (WHO, 2018). For more information on GV derivation, see the GDWQ (WHO, 2017) and the Policies and Procedures for Updating the WHO GDWQ (WHO, 2009b).

These values describe concentrations in drinking-water and water used for recreation that are not a significant risk to human health. For some of these toxin groups, it was possible to derive values for lifetime exposure and for others only for short-term or acute exposure (see Table 5.1 for a summary of the values established). The corresponding sections in Chapter 2 present the derivation of these values and a short summary of the considerations leading to them; for an extensive discussion, readers are referred to the cyanotoxin background documents on the WHO Water, Sanitation and Health website (WHO, 2020). For a summary on how guideline values are derived, see Box 2.1, and for further information, see also the "Guidelines for Drinking Water Quality” (WHO, 2017).

\section{REFERENCES}

Davis JA, Gift JS, Zhao QJ (2011). Introduction to benchmark dose methods and US EPA's benchmark dose software (BMDS) version 2.1. 1. Toxicol Appl Pharmacol. 254:181-191.

WHO (2003). Guidelines for safe recreational water environments. Vol. 1: Coastal and fresh waters. Geneva: World Health Organization. https://apps.who.int/ iris/handle/10665/42591

WHO (2009a). Principles and methods for the risk assessment of chemicals in food. Geneva: World Health Organization. Environmental health criteria 240. https://apps.who.int/iris/handle/10665/44065 
WHO (2009b). WHO Guidelines for drinking-water: quality policies and procedures used in updating the WHO guidelines for drinking-water quality. Geneva: World Health Organization. https://apps.who.int/iris/handle/10665/70050

WHO (2017). Guidelines for drinking-water quality, fourth edition, incorporating the 1st addendum. Geneva: World Health Organization:631 pp. https://www. who.int/publications/i/item/9789241549950

WHO (2018). Developing drinking-water quality regulations and standards. Geneva: World Health Organization. https://apps.who.int/iris/handle/10665/272969

WHO (2020). Cyanobacterial toxins: Anatoxin-a and analogues; Cylindrospermopsins; Microcystins; Saxitoxins. Background documents for development of WHO Guidelines for Drinking-water Quality and Guidelines for Safe Recreational Water Environments. Geneva: World Health Organization. https:/www.who.int/teams/environment-climatechange-and-health/water-sanitation-and-health/water-safety-and-quality/ publications 


\title{
2.I HEPATOTOXIC CYCLIC PEPTIDES - MICROCYSTINS AND NODULARINS
}

\author{
Jutta Fastner and Andrew Humpage
}

The cyclic peptides microcystins and nodularins are frequently found in fresh and brackish waters, and the acute and chronic toxicity of some of them is pronounced. WHO has established provisional guideline values for microcystin-LR in drinking-water and water for recreational use (see below) but recommends that these values may be used for the sum of all microcystins in a sample (see WHO, 2020). Microcystin-LR occurs widely and is presumably one of the most toxic variants of this toxin family, though for most of the other congeners no, or only incomplete, toxicological data exist (WHO, 2003a; Buratti et al., 2017).

\section{I.I Chemical structures}

The cyclic heptapeptide microcystins were first characterised in the early 1980s and named after the cyanobacterium Microcystis aeruginosa from which they were initially isolated (Botes et al., 1984; Botes et al., 1985; Carmichael et al., 1988). Microcystins share a common structure of cyclo- $\left(D-\mathrm{Ala}^{1}-\mathrm{X}^{2}-D-\mathrm{MeAsp}^{3}-\mathrm{Z}^{4}-\mathrm{Adda}^{5}-D-\mathrm{Glu}^{6}-\mathrm{Mdha}^{7}\right)$ in which $\mathrm{X}$ and $\mathrm{Z}$ are variable $L$-amino acids, $D$-MeAsp is $D$-erythro- $\beta$-methylaspartic acid, and Mdha is $N$-methyldehydroalanine (Figure 2.1). The amino acid Adda, abbreviated for $(2 S, 3 S, 4 E, 6 E, 8 S, 9 S)$-3-amino-9-methoxy-2,6,8trimethyl-10-phenyldeca-4,6-dienoic acid, is the most characteristic moiety of microcystins and nodularins (including the structurally related motuporins from sponges) as it appears to occur exclusively in these cyanobacterial peptides. Further characteristics are the presence of $D$-amino acids, which are usually not found in ribosomally synthesised peptides and thus gave an early indication of a nonribosomal synthesis of these peptides (see below).

To date more than 250 different variants of microcystins are fully characterised, with molecular weights in the range of 800-1100 Da. While a comprehensive list of variants is given in Spoof and Catherine (2017) and a detailed review on structural variants can be found in Bouaïcha et al. (2019), this volume lists only the apparently most abundant congeners in Table 2.1. Structural modifications exist in all seven amino acids, but the most frequent variations are substitution of $L$-amino acids at positions 2 and 4 , substitution of Mdha by Dhb (dehydrobutyrine) or serine in position 7, and a lack of methylation of amino acids at positions 3 and/or 7 (Figure 2.1). The 
(a)

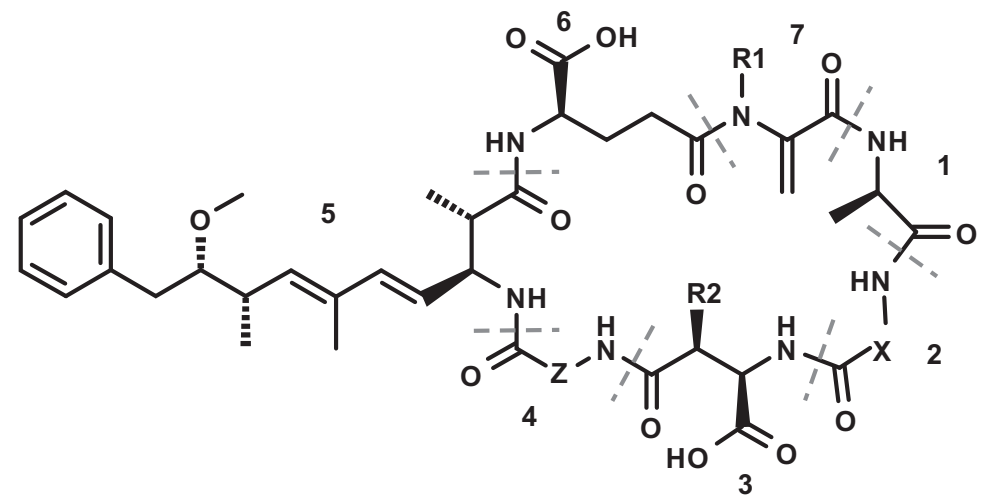

(b)

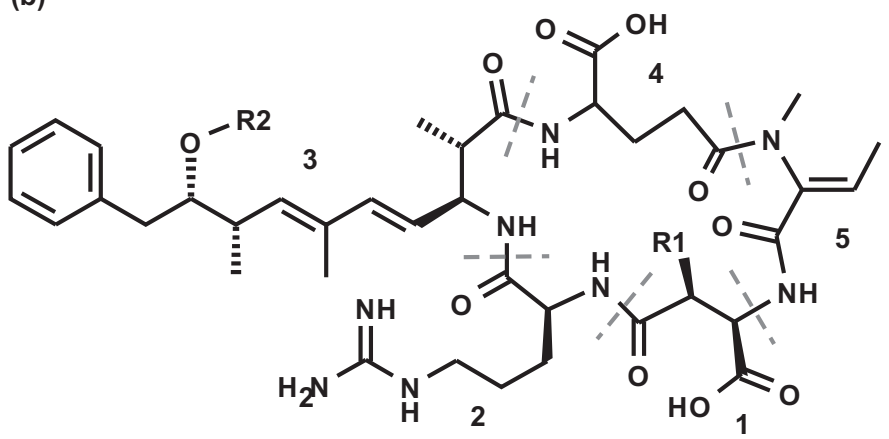

Figure 2.I Generic structure of microcystins (a, MCs) and nodularins (b, NODs). In MCs, amino acids in positions 2 and 4 given as $X$ and $Z$ for variable amino acids that are generally given by the one-letter code for proteinogenic $L$-amino acids. For example, $\mathrm{L}=\mathrm{L}$-leucine. $\mathrm{R}=\mathrm{L}$-arginine. $\mathrm{A}=\mathrm{L}$-alanine. General structure of MCs is cyclo-(DAla'-X2-D-MeAsp ${ }^{3}-Z^{4}-$ Adda $\left.^{5}-D-G^{2} u^{6}-M_{d h a}{ }^{7}\right)$. RI and $\mathrm{R} 2$ is either $\mathrm{H}$ (desmethyl-variants) or $\mathrm{CH}_{3}$. The general structure of NOD is cyclo-(D-MeAsp'-Arg $\left.{ }^{2}-\mathrm{Adda}^{3}-\mathrm{D}-\mathrm{Glu}^{4}-\mathrm{Mdhb}^{5}\right)$. Nodularin: RI. R2 $=\mathrm{CH}_{3}$; D-Asp'Nodularin: $\mathrm{RI}=\mathrm{H}$. $\mathrm{R} 2=\mathrm{CH}_{3}$; demethyl-Adda ${ }^{3}$ Nodularin: $\mathrm{RI}=\mathrm{CH}_{3}$. $\mathrm{R} 2=\mathrm{H}$. In motuporin, the $\mathrm{L}$-arginine in position 2 of nodularin is exchanged by an L-valine. For more variants and details on amino acid building blocks, see text. Note that the numbering does not correspond to the biosynthesis pathway that starts with Adda in both MC and NOD, but has been assigned arbitrarily in the first descriptions of the molecule.

principle nomenclature of microcystins is based on the variable amino acids in positions 2 and 4; for example, using the standard one-letter codes for amino acids, microcystin-LR possesses leucine (L) in position 2 and arginine (R) in position 4, respectively (Carmichael et al., 1988). All other modifications vin the molecule are suffixed to the respective variant; for example, [Asp $\left.{ }^{3}\right]$ MC-LR lacks the methyl group in position 3. 
Nodularins, named after the cyanobacterium Nodularia spumigena, are cyclic pentapeptides structurally very similar to microcystins (Rinehart et al., 1988). The chemical structure of nodularin is cyclo-(D-MeAsp'$L$-arginine ${ }^{2}-\mathrm{Adda}^{3}-D$-glutamate $\left.{ }^{4}-\mathrm{Mdhb}^{5}\right)$, in which the amino acids in positions 1-4 are identical to microcystins and Mdhb is 2-(methylamino)2-dehydrobutyric acid (Figure 2.1). Structural variability of nodularins is low compared to microcystins: in addition to the unmodified nodularin with the arginine residue, only a few more variants with (de)methylation

Table 2.I Selection of microcystin structural variants reported in relatively high abundance

\begin{tabular}{|c|c|c|c|c|}
\hline Microcystin variant & $\begin{array}{l}\text { Monoisotopic } \\
\text { molecular } \\
\text { mass (Da) }\end{array}$ & $\begin{array}{l}\text { Molecular } \\
\text { weight } \\
(\mathrm{g} / \mathrm{mol})\end{array}$ & $\begin{array}{l}L D_{50} \\
\text { i.p. (oral) }\end{array}$ & Reference \\
\hline MC-LA & 909.485 & 910.08 & 50 & $\begin{array}{l}\text { Botes et al. }(1984) \\
\text { Stoner et al. }(1989)\end{array}$ \\
\hline$\left[\mathrm{Asp}^{3}, \mathrm{Dha}^{7}\right] \mathrm{MC}-\mathrm{LR}$ & 966.517 & 967.14 & + & $\begin{array}{l}\text { Harada et al. (1991a) } \\
\text { Namikoshi et al. (1992c) }\end{array}$ \\
\hline$\left[\mathrm{Asp}^{3}\right] \mathrm{MC}-\mathrm{LR}$ & 980.533 & 981.16 & $160-300$ & $\begin{array}{l}\text { Krishnamurthy et al. } \\
(1989) \\
\text { Harada et al. (1990) }\end{array}$ \\
\hline$\left[\mathrm{Dha}^{7}\right] \mathrm{MC}-\mathrm{LR}$ & 980.533 & 981.16 & 250 & $\begin{array}{l}\text { Namikoshi et al. (1992a) } \\
\text { Harada et al. (1991b) }\end{array}$ \\
\hline MC-LF & 985.516 & 986.18 & + & $\begin{array}{l}\text { Azevedo et al. (1994) } \\
\text { Diehnelt et al. (2006) }\end{array}$ \\
\hline MC-LR & 994.549 & 995.19 & $\begin{array}{c}50 \\
(5000)\end{array}$ & $\begin{array}{l}\text { Botes et al. (1985) } \\
\text { Krishnamurthy et al. } \\
(1986) \\
\text { Krishnamurthy et al. } \\
(1989) \\
\text { Fawell et al. (1994) }\end{array}$ \\
\hline MC-LY & 1001.511 & 1002.18 & 90 & $\begin{array}{l}\text { del Campo \& } \\
\text { Ouahid (2010) } \\
\text { Stoner et al. (1989) }\end{array}$ \\
\hline$\left[\mathrm{Asp}^{3}, \mathrm{Dha}^{7}\right] \mathrm{MC}-\mathrm{RR}$ & 1009.535 & 1010.16 & + & $\begin{array}{l}\text { Krishnamurthy et al. } \\
(1989) \\
\text { Sivonen et al. (1992a) }\end{array}$ \\
\hline$\left[\mathrm{Asp}^{3}\right] \mathrm{MC}-\mathrm{RR}$ & 1023.550 & 1024.19 & 250 & $\begin{array}{l}\text { Meriluoto et al. (1989) } \\
\text { Namikoshi et al. (1992d) }\end{array}$ \\
\hline$\left[\mathrm{Dha}^{7}\right] \mathrm{MC}-\mathrm{RR}$ & 1023.550 & 1024.19 & 180 & Kiviranta et al. (1992) \\
\hline$\left[\mathrm{Asp}^{3},(\mathrm{E})-\mathrm{Dhb}^{7}\right] \mathrm{MC}-\mathrm{RR}$ & 1023.550 & 1024.19 & 250 & $\begin{array}{l}\text { Sano \& Kaya (1995) } \\
\text { Sano \& Kaya (1998) }\end{array}$ \\
\hline MC-LW & 1024.527 & 1025.21 & n.r. & Bateman et al. (1995) \\
\hline$\left[\mathrm{Asp}^{3}, \mathrm{Dha}^{7}\right] \mathrm{MC}-\mathrm{HtyR}$ & 1030.512 & 1031.18 & + & Namikoshi et al. (1992b) \\
\hline$\left[\mathrm{Asp}^{3}\right] \mathrm{MC}-\mathrm{YR}$ & 1030.512 & 1031.18 & + & Namikoshi et al. (1992d) \\
\hline$\left[\mathrm{Dha}^{7}\right] \mathrm{MC}-\mathrm{YR}$ & 1030.512 & 1031.18 & + & Sivonen et al. (1992b) \\
\hline
\end{tabular}


Table 2.I (Continued) Selection of microcystin structural variants reported in relatively high abundance

\begin{tabular}{|c|c|c|c|c|}
\hline Microcystin variant & $\begin{array}{c}\text { Monoisotopic } \\
\text { molecular } \\
\text { mass (Da) }\end{array}$ & $\begin{array}{l}\text { Molecular } \\
\text { weight } \\
\text { (g/mol) }\end{array}$ & $\begin{array}{l}L D_{50} \\
\text { i.p. (oral) }\end{array}$ & Reference \\
\hline MC-RR & 1037.566 & 1038.22 & 600 & $\begin{array}{l}\text { Namikoshi et al. (1992a) } \\
\text { Kusumi et al. (1987) }\end{array}$ \\
\hline$\left[\right.$ Asp $\left.^{3}\right]$ MC-HtyR & 1044.528 & 1045.21 & $160-300$ & Harada et al. (199la) \\
\hline$\left[\mathrm{Dha}^{7}\right] \mathrm{MC}-\mathrm{HtyR}$ & 1044.528 & 1045.21 & + & Namikoshi et al. (1992b) \\
\hline$\left[\mathrm{Asp}^{3},(\mathrm{E})-\mathrm{Dhb}^{7}\right] \mathrm{MC}-\mathrm{HtyR}$ & 1044.528 & 1045.21 & 70 & Sano \& Kaya (1998) \\
\hline MC-YR & 1044.528 & 1045.21 & 70 & $\begin{array}{l}\text { Botes et al. (1985) } \\
\text { Namikoshi et al. (1992a) }\end{array}$ \\
\hline MC-WR & 1067.544 & 1068.24 & $150-200$ & Namikoshi et al. (1992a) \\
\hline
\end{tabular}

Molecular weight (MW) is given as monoisotopic mass; LD50 in $\mu \mathrm{g} / \mathrm{kg}$ body weight intraperitoneal (i.p.) injection in mouse bioassays or by oral dosing (values in parentheses) where data are available.

+: positive toxicity in mouse bioassay; n.r.: not reported.

at the Adda, MeAsp, Mdhb and D-Glu moieties, as well as the non-toxic 6Z-Adda3 stereoisomer equivalent to microcystins, have been identified (Namikoshi et al., 1994; Mazur-Marzec et al., 2006b). Ten nodularins in total have been reported (Spoof \& Catherine, 2017).

All microcystins and nodularins are water soluble despite the relatively wide range of hydrophobicity observed especially for microcystins. They are extremely stable and remain potent even after boiling (Harada, 1996).

\section{I.2 Toxicity: mode of action}

The toxic effects of microcystin, summarised in the following, are described in detail in the WHO Background Document on Microcystins (WHO, 2020; see there for further information and references). In summary, microcystins need a membrane transporter to enter cells - that is, the organic acid transporter polypeptides (OATP) which are expressed particularly in the liver but also in the intestinal tract and in some other tissues. Experiments have shown that when OATP is inhibited or lacking, liver damage is reduced. The essential role of OATP explains why most of the MCs ingested are taken up by the liver. While detoxification occurs in the liver, clearance of MCs seems to take a long time, up to weeks. Once in cells, MCs cause protein phosphatase (PP1, PP2A and PP5) inhibition, resulting in destabilisation of the cytoskeleton followed by cellular apoptosis and necrosis. High acute doses thus cause haemorrhage in the liver due to the damage of sinusoidal capillaries. At low doses (below $20 \mu \mathrm{g} / \mathrm{kg}$ bw) and with repeated long-term exposure, phosphatase inhibition induces cellular proliferation, hepatic hypertrophy and tumour promoting activity. 
There is a growing body of evidence indicating harmful microcystin-related neurological and reproductive effects, but the data are not yet robust enough to use as a basis for guideline development.

While some cyanobacterial extracts show genotoxicity, pure microcystins do not, and cellular DNA damage observed after in vitro treatments with pure MC may be due to the induction of apoptosis and cytotoxicity rather than direct effects on the DNA. On this basis, IARC has classified microcystins as Group 2B, possibly carcinogenic to humans (IARC, 2010), based on their tumour promoting activity mediated via protein phosphatase inhibition (a threshold effect) rather than genotoxicity.

\section{I.3 Derivation of provisional guideline values}

The following section is taken directly from the WHO chemicals background document on microcystins which discusses the considerations for the derivation of provisional guideline values for exposure to microcystins in more detail (WHO, 2020). Insufficient data are available to derive a GV for MC variants except MC-LR. The two key oral toxicity studies of the effects of MC-LR on liver toxicity on which human health-based guideline values can be calculated are the following:

- Fawell et al. (1999): Mice of both sexes given MC-LR by gavage at $40 \mu \mathrm{g} / \mathrm{kg}$ bw per day for 13 weeks did not show treatment-related effects in the parameters measured. Only slight hepatic damage was observed at the lowest observed effect level (LOAEL) of $200 \mu \mathrm{g} / \mathrm{kg}$ bw per day in a limited number of treated animals, whereas at the highest dose tested ( $1 \mathrm{mg} / \mathrm{kg}$ bw per day), all the animals showed hepatic lesions, consistent with the known action of MC-LR.

- Heinze (1999): Exposure of male rats (females were not included) to MC-LR in drinking-water for 28 days at doses as low as $50 \mu \mathrm{g} / \mathrm{kg}$ bw per day (identified as the LOAEL) resulted in increased liver weight, liver lesions (with haemorrhages) and increased ALP (alkaline phosphatase) and LDH (lactate dehydrogenase), but no changes were measured in the mean levels of AST (aspartate aminotransferase) and ALT (alanine aminotransferase) which are early markers for hepatotoxicity. Some of the histological effects, including Kupffer cell activation and PAS staining, showed no dose response since all 10 animals at the low and high doses displayed a similar degree of damage.

Although the duration of the Heinze (1999) study was shorter and more applicable to the exposure duration envisaged for application of the shortterm guideline value, the advantage of the Fawell et al. (1999) study is that an additional uncertainty factor is not needed for extrapolation from a LOAEL to a NOAEL, which would increase the total uncertainty and 
reduce the confidence in the derivation of the short-term guideline value. For this reason, the NOAEL derived by Fawell et al. (1999) was selected as the basis for the short-term and recreational guideline values as well as the lifetime guideline value.

The GVs for MC-LR are considered provisional due to inadequacies in the database as reflected in section 6.2 of the background document (WHO, 2020) and the database uncertainty factor (UF) of 1000 for the lifetime GV.

\section{Calculation of provisional tolerable daily intake for microcystin-LR}

$$
\mathrm{TDI}_{\text {chronic }}=\frac{\mathrm{NOAEL}}{\mathrm{UF}}=\frac{40}{1000} \frac{\mu \mathrm{g}}{\mathrm{kg}} / \mathrm{d}=0.04 \frac{\mu \mathrm{g}}{\mathrm{kg}} / \mathrm{d}
$$

where

$\mathrm{TDI}_{\mathrm{MC}, \text { chronic }}=$ tolerable daily intake for chronic exposure

NOAEL $=$ no-observed-adverse-effect level $(40 \mu \mathrm{g} / \mathrm{kg}$ bw per day, based on Fawell et al., 1999)

$\mathrm{UF}=$ uncertainty factor $(1000=10$ for interspecies variation $\times 10$ for intraspecies variation $\times 10$ for database deficiencies, including use of a subchronic study)

For comparison, if the LOAEL from Heinze (1999) is used as the point of departure and incorporating uncertainty factors of 10 for inter- and intraspecies variability and 10 for database uncertainties including the use of a LOAEL (as per WHO policy), then the TDI would be $0.05 \mu \mathrm{g} / \mathrm{kg}$ per day.

\section{Calculation of provisional lifetime drinking-water guideline value for microcystin-LR}

$$
\mathrm{GV}_{\text {chronic }}=\frac{\mathrm{NOAEL}^{*} \mathrm{bw}^{*} P}{\mathrm{UF}^{*} \mathrm{C}}=\frac{40 * 60 * 0.8}{1000 * 2} \mu \mathrm{g} / \mathrm{L}=0.96 \mu \mathrm{g} / \mathrm{L} \approx 1 \mu \mathrm{g} / \mathrm{L}
$$

where

$\mathrm{GV}_{\text {chronic }}=$ guideline value for chronic (lifetime) exposure

NOAEL $=$ no-observed-adverse-effect level $(40 \mu \mathrm{g} / \mathrm{kg}$ bw per day, based on Fawell et al., 1999)

bw $=$ body weight $($ default $=60 \mathrm{~kg}$ for an adult $)$

$\mathrm{P}=$ fraction of exposure allocated to drinking-water $(80 \%$, as other sources of exposure such as air, food and soil are considered minor for lifetime exposure) 
$\mathrm{UF}=$ uncertainty factor $(1000=10$ for interspecies variation $\times 10$ for intraspecies variation $\times 10$ for database deficiencies, including use of a subchronic study)

$\mathrm{C}=$ daily drinking-water consumption (default $=2 \mathrm{~L}$ for an adult).

\section{Calculation of provisional short-term} drinking-water guideline value for microcystin-LR

$$
\mathrm{GV}_{\text {short-term }}=\frac{\text { NOAEL*bw*P }}{\mathrm{UF}^{*} \mathrm{C}}=\frac{40 * 60 * 1.0}{100 * 2} \mu \mathrm{g} / \mathrm{L}=12 \mu \mathrm{g} / \mathrm{L}
$$

where

$\mathrm{GV}_{\text {short-term }}=$ guideline value for short-term exposure

NOAEL $=$ no-observed-adverse-effect level $(40 \mu \mathrm{g} / \mathrm{kg}$ bw per day, based on Fawell et al., 1999)

$\mathrm{bw}=$ body weight $($ default $=60 \mathrm{~kg}$ for an adult $)$

$\mathrm{P}=$ fraction of exposure allocated to drinking-water (default for shortterm exposure $=100 \%$, as drinking-water is expected to be the most significant source of exposure)

$\mathrm{UF}=$ uncertainty factor $(100=10$ for interspecies variation $\times 10$ for intraspecies variation)

$\mathrm{C}=$ daily drinking-water consumption (default $=2 \mathrm{~L}$ for an adult).

\section{Calculation of provisional recreational water guideline value for microcystin-LR}

$$
\mathrm{GV}_{\text {recreation }}=\frac{\text { NOAEL } * \mathrm{bw}}{\mathrm{UF}^{*} \mathrm{C}}=\frac{40 * 15}{100 * 0.25} \mu \mathrm{g} / \mathrm{L}=24 \mu \mathrm{g} / \mathrm{L}
$$

where

$\mathrm{GV}_{\text {recreation }}=$ guideline value for recreational exposure

NOAEL $=$ no-observed-adverse-effect level $(40 \mu \mathrm{g} / \mathrm{kg}$ bw per day, based on Fawell et al., 1999)

$\mathrm{bw}=$ body weight $($ default $=15 \mathrm{~kg}$ for a child $)$

UF $=$ uncertainty factor $(100=10$ for interspecies variation $\times 10$ for intraspecies variation)

$\mathrm{C}=$ daily incidental water consumption (default $=250 \mathrm{~mL}$ for a child).

The provisional recreational guideline value, aimed to protect from systemic effects, is based on exposure of a child because the lower body weight and higher likely water intake (as a function of body weight) were considered 
worst case, and on a conservative scenario of a $15 \mathrm{~kg}$ child swallowing $250 \mathrm{~mL}$ of water (WHO, 2003b).

\section{Considerations in applying the provisional guideline values}

The provisional guideline values are based on toxicological data for MC-LR. However, MCs usually occur as mixtures. In the absence of oral toxicity data for other congeners, it is recommended that these values be applied to total MCs as gravimetric or molar equivalents based on the assumption that all MCs have similar toxicity to MC-LR. The kinetic differences among variants mean that further investigation of the oral toxicity of MC variants other than MC-LR is warranted reduce this relevant source of uncertainty.

In some regions, other sources of exposure besides drinking-water can be significant (see section 2.4). This includes food from locations where blooms have a long duration and there is high consumption of locally affected food items (e.g. fish eaten with viscera, or shellfish). In such situations, it may be appropriate to consider reducing the allocation factor for the lifetime and short-term drinking-water GVs based on relative exposure data for the population.

The short-term drinking-water GV is intended to provide guidance on how much the lifetime GV can be exceeded for short periods of about 2 weeks until enhanced water treatment or other measures can be implemented. It is not intended to allow for repeated seasonal exceedances of the lifetime GV.

The short-term drinking-water guideline value is based on exposure of adults. Since infants and children can ingest a significantly larger volume of water per body weight (e.g., up to 5 times more drinking-water $/ \mathrm{kg}$ bw for bottle-fed infants compared to adults), it is recommended that alternative water sources such as bottled water are provided for bottle-fed infants and small children when MC concentrations are greater than $3 \mu \mathrm{g} / \mathrm{L}$ for short periods, as a precautionary measure.

\subsubsection{Production}

\section{I.4.I Producing cyanobacteria}

Qualitative and quantitative information on microcystin production in particular cyanobacterial species has been gathered through analyses of quasimonospecific bloom material and, more importantly, large numbers of individual strains isolated from freshwater samples. More recent studies employ sensitive molecular and chemical tools such as PCR, mass spectrometry or ELISA to determine toxins or genes related to their production directly in colonies or filaments picked from water samples. This helps to avoid bias due to eventually selective isolation procedures and allows more detailed studies 
on the ecology of toxin-producing cyanobacteria. Furthermore, molecular tools are applied to clarify the taxonomic status of toxin-producing cyanobacteria and to complement the identification of toxin producers by verifying the presence of genes encoding toxin biosynthesis (see section 13.6).

Microcystin-producing strains can be found in all higher-level taxa of cyanobacteria, that is, in species belonging to the orders Chroococcales, Oscillatoriales, Nostocales, and Stigonematales; data for the order Pleurocapsales, however, are scarce. Within the orders, the distribution of microcystin occurrence at the level of genera or species is patchy and does not show consistency. Firstly, not all genera of an order produce microcystins; for example in the order Nostocales, microcystins are produced by members of the genera Dolichospermum (Anabaena) and Nostoc, but have never been confirmed for the closely related genus Aphanizomenon. Secondly, any particular genus or species may contain both producing (toxigenic) and nonproducing strains. At the time of the publication of this book, microcystin-producing (and nonproducing) strains are known primarily from freshwater species of Microcystis, Planktothrix, Dolichospermum, and Nostoc (Sivonen \& Jones, 1999; Oksanen et al., 2004; Mowe et al., 2015; Harke et al., 2016; Bernard et al., 2017; Buratti et al., 2017; Table 2.2). Very rarely, microcystins have been reported in single strains from other genera, including Anabaenopsis, Arthrospira, Fischerella, Pseudanabaena, Phormidium, Synechococcus and Radiocystis (Ballot et al., 2005; Carmichael \& Li, 2006; Lombardo et al., 2006; Izaguirre et al., 2007; Nguyen et al., 2007; Mohamed \& Al Shehri, 2009; Cirés et al., 2014; Table 2.2).

Most of these cyanobacteria are of planktonic nature and some of them, like Microcystis, are known for their ability to form surface blooms under favourable conditions (see Chapter 4). Microcystins have also been detected in halophilic Synechococcus and Dolichospermum (Anabaena) from the Baltic Sea (Carmichael \& Li, 2006; Halinen et al., 2007).

Microcystin-producing strains of the genera listed above are distributed globally and can be found in tropical, temperate and polar habitats (Hitzfeld et al., 2000; Mowe et al., 2015; Harke et al., 2016) as well as in extreme habitats such as hot springs and hypersaline lakes (Carmichael \& Li, 2006; Kotut et al., 2006). Microcystins have also been detected in a symbiotic strain of Nostoc in a lichen (Oksanen et al., 2004) and in a soil isolate of Haphalosiphon hibernicus (Prinsep et al., 1992).

Nodularins have so far been found largely in strains of the genus Nodularia, primarily in Nodularia spumigena. Toxigenic strains of Nodularia spumigena have been reported from the Baltic Sea, brackish water estuaries and coastal freshwater lakes of Australia, South Africa, New Zealand and Turkey (Bolch et al., 1999; Akçaalan et al., 2009). As with microcystins, both nodularin-producing and nonproducing strains exist in this species (Lehtimäki et al., 1994; Bolch et al., 1999). In addition, single findings of nodularin in Nodularia sphaerocarpa from a hot spring, in a symbiotic Nostoc, and 
Table 2.2 Cyanobacterial taxa potentially producing microcystins and nodularins

\begin{tabular}{|c|c|c|}
\hline Toxin & Taxon & Habitat \\
\hline \multirow[t]{21}{*}{ Microcystin } & Microcystis sp. & Planktonic \\
\hline & Dolichospermum (Anabaena) sp. & Planktonic \\
\hline & Planktothrix agardhii & Planktonic \\
\hline & Planktothrix rubescens & Planktonic \\
\hline & Radiocystis sp. & Planktonic \\
\hline & Arthrospira sp. & Planktonic \\
\hline & Anabaenopsis sp. & Planktonic \\
\hline & Calothrix sp. & Planktonic \\
\hline & Oscillatoria sp. & Planktonic \\
\hline & Fischerella sp. & Planktonic, benthic \\
\hline & Annamia toxica & Planktonic \\
\hline & Synechococcus sp. & Planktonic \\
\hline & Pseudanabaena sp. & Planktonic \\
\hline & Phormidium sp. & Planktonic \\
\hline & Anabaena sp. & Benthic \\
\hline & Nostoc sp. & $\begin{array}{l}\text { Planktonic, benthic, } \\
\text { symbiotic (lichen) }\end{array}$ \\
\hline & Aphanocapsa sp. & Planktonic \\
\hline & Plectonema sp. & Benthic \\
\hline & Leptolyngbya sp. & Symbiotic (coral), periphytic \\
\hline & Merismopedia sp. & Periphytic \\
\hline & Haphalosiphon hibernicus & Terrestrial \\
\hline \multirow[t]{4}{*}{ Nodularin } & Nodularia spumigena & Planktonic \\
\hline & Nodularia sp. & Benthic \\
\hline & Nostoc sp. & Symbiotic (lichen) \\
\hline & Iningainema pulvinus & Benthic \\
\hline
\end{tabular}

Only cyanobacteria are listed for which toxin production was verified in cultured strains by NMR, mass spectrometry or by combinations of HPLC-PDA, ELISA, toxicity testing and/or molecular detection of mcy genes. References earlier than 1999 are summarised in Sivonen \& Jones (1999). In bold are taxa that are known to frequently produce microcystins and that can form blooms.

in the benthic Iningainema pulvinus (Nostocales) from Australia have been reported (Beattie et al., 2000; Gehringer et al., 2012; McGregor \& Sendall, 2017). Occasionally, nodularin has been detected in pelagic and benthic freshwater ecosystems in which none of the known nodularin producers could be identified, indicating that further species may be identified as nodularin producers in future (Graham et al., 2010; Wood et al., 2012; Beversdorf et al., 2017). 


\subsubsection{Microcystin/nodularin profiles}

Although many toxigenic strains simultaneously produce several microcystin variants (Puddick et al., 2014), usually only one to three of them are dominant in any particular strain. It appears that some microcystin variants are more abundant within a certain genus than within others, though this may be biased in some cases by the limited availability of standards as well as the analytical methods used.

Globally, Microcystis strains and field samples dominated by Microcystis spp. are reported to contain chiefly microcystin-LR, -RR and -YR in varying proportions (Sivonen \& Jones, 1999; Vasconcelos, 2001; Gkelis et al., 2005; Kemp \& John, 2006; Faassen \& Lürling, 2013; Mowe et al., 2015; Beversdorf et al., 2017). Demethylated variants of, for example, [Dha $\left.{ }^{7}\right] \mathrm{MC}-\mathrm{LR}$ and $-\mathrm{RR}$ are also observed in Microcystis strains, but are less frequently dominant compared to their methylated forms (Vasconcelos, 2001; Gkelis et al., 2005). More hydrophobic microcystins (e.g., MC-LA, MC-LW, MC-LF) can also be found regularly in Microcystis strains and field samples; however, high proportions are reported only infrequently (Cuvin-Aralar et al., 2002; Wood et al., 2006; Graham et al., 2010; Faassen \& Lürling, 2013; Beversdorf et al., 2017). This picture of a high diversity combined with an abundance of genotypes with a certain microcystin profile has been confirmed in situ for some natural Microcystis populations from central Europe. Typing of single Microcystis colonies from nine European countries by mass spectrometry revealed a high abundance of genotypes producing microcystin-LR, -RR and $-\mathrm{YR}$, while clones with demethylated variants or other microcystins were less abundant (Via-Ordorika et al., 2004). However, exceptions from this overall pattern occur; for example, in Microcystis strains and colonies from Finland, demethylated MC-LR and -RR have been seen frequently as dominant variants (Luukkainen et al., 1994; Via-Ordorika et al., 2004), and in one Australian bloom of Microcystis, 23 microcystins were detected, none of which was microcystin-LR (Jones et al., 1995).

Planktothrix and some strains of Dolichospermum seem to produce only demethylated microcystins (Puddick et al., 2014). In European Planktothrix agardhii and $P$. rubescens isolates, cultured strains and field samples primarily produce demethylated variants of microcystin-RR like [D-Asp $\left.{ }^{3}\right]$ MC-RR and $\left[\mathrm{D}-\mathrm{Asp}^{3}, \mathrm{Dhb}^{7}\right] \mathrm{MC}-\mathrm{RR}$ that have been found as major microcystins (Sivonen et al., 1995; Fastner et al., 1999; Briand et al., 2005; Kurmayer et al., 2005; Cerasino et al., 2016). Various other demethylated microcystins such as $\left[\mathrm{D}-\mathrm{Asp}^{3}\right]$ MC-LR or [D-Asp $\left.{ }^{3}\right]$ MC-HtyR are also found in Planktothrix isolates but are rarely the dominant variants (Kosol et al., 2009). As with Microcystis, multiple clones with different microcystin profiles exist in natural populations of Planktothrix (Welker et al., 2004; Haruštiaková \& Welker, 2017).

Only few data exist on microcystin congeners produced by benthic species, and detected variants comprise MC-LR, MC-RR, MC-YR, MC-LA, 
$\left[\mathrm{Asp}^{3}\right]$ MC-LR as well as unidentified microcystins (Aboal \& Puig, 2005; Jungblut et al., 2006; Izaguirre et al., 2007; Fetscher et al., 2015).

Nodularin-R seems the major nodularin present in samples from the Baltic Sea, Turkey and Australia, while other nodularin variants usually seem less abundant (Sivonen et al., 1989; Jones et al., 1994a; Lehtimaki et al., 1997; Mazur-Marzec et al., 2006b; Akçaalan et al., 2009).

\section{I.4.3 Biosynthesis}

Knowledge of the biosynthesis of microcystins and nodularins has increased since the turn of the millennium. Complete sequences of biosynthesis gene clusters are available for several species, and biochemical pathways are largely understood (Pearson et al., 2016).

Microcystins and nodularins are synthesised by a combined nonribosomal peptide synthetase (NRPS) and polyketide synthase (PKS) pathway, which is well known for the synthesis of peptide antibiotics in bacteria and fungi, including penicillins (Kleinkauf \& Döhren, 1996; Dittmann \& Börner, 2005). Microcystins are produced by large multienzyme complexes consisting of peptide synthetases, polyketide synthases and tailoring enzymes. These enzymes activate specific amino acids and condense them to peptides. The genes encoding for microcystin synthetases (mcyA-mcyJ) have been characterised for Microcystis, Dolichospermum, Fischerella, Nostoc and Planktothrix (Tillett et al., 2000; Christiansen et al., 2003; Rouhiainen et al., 2004; Fewer et al., 2013; Shih et al., 2013). The biosynthesis of nodularins is encoded by homologous genes (ndaA-ndaI) that have been characterised from Nodularia (Moffitt \& Neilan, 2004). Both the microcystin and nodularin gene clusters comprise around $50 \mathrm{~kb}$ pairs in all investigated species, but differences in the gene order as well as DNA sequence variation in the same modules have been observed. Based on coding nucleotide sequences, Rantala et al. (2004) concluded that microcystin synthetase genes have already been present in an early stage of cyanobacterial evolutionary history.

Microcystin and nodularin production appears to be constitutive in genotypes which have the complete microcystin gene clusters, while it is absent in genotypes lacking the whole or relevant parts of the gene cluster (Christiansen et al., 2008; Tooming-Klunderud et al., 2008). Smaller mutations in single $m c y$ genes can lead to genotypes unable to synthesise microcystin (Kurmayer et al., 2004; Christiansen et al., 2006; Fewer et al., 2008).

\section{I.4.4 Regulation of biosynthesis}

Microcystin contents or cell quota can vary greatly between individual clones within a natural population (e.g., Rohrlack et al., 2001; Akçaalan et al., 
2006). Reported microcystin contents in isolates (cultures) of Microcystis and Planktothrix range over more than two orders of magnitude, from below $100 \mu \mathrm{g}$ up to more than $10 \mathrm{mg} / \mathrm{g}$ dry weight, from traces up to $20 \mu \mathrm{g} /$ $\mathrm{mm}^{3}$ biovolume and from a few to around $1000 \mathrm{fg} / \mathrm{cell}$ (Table 2.3).

While qualitative microcystin production is regarded as constitutive, numerous studies on Microcystis, Planktothrix, Dolichospermum and Nodularia have investigated to which extent the cell quota may be altered by environmental factors. The environmental factors investigated included temperature, light, $\mathrm{pH}$, macronutrients, trace elements and salinity (reviewed in Sivonen \& Jones, 1999; Kardinaal \& Visser, 2005; Pearson et al., 2016). Though all the studies showed an effect on microcystin content or cell quota, respectively, they show no consistent pattern in the regulation of the microcystin cell quota. These inconsistencies can partly be explained by large differences between the studies with respect to culture conditions (i.e., batch, semi- and continuous; see Box 4.11), toxin measurement (i.e., ELISA, HPLC), as well as by the biomass proxy to which the toxin content was related (i.e., dry weight, biovolume, cell number, protein or chlorophyll-a). Another explanation for the differences in cell quota changes may be a clone-specific binding rate of synthesised microcystins to proteins, which is then not available to conventional analysis, thus leading to underestimation of microcystin contents (Meissner et al., 2013). To add to this complexity, individual clones of the same species can respond differently, even conversely, in microcystin contents to the same cultivation condition (Hesse \& Kohl, 2001).

One pattern of changes in the microcystin content which unifies many of the earlier disparate results is the positive correlation between growth and microcystin content under growth conditions limited by nitrogen, phosphorus or light (Kardinaal \& Visser, 2005). However, some studies observed this relationship only during exponential growth, while no or a negative relationship existed during the stationary phase (Wiedner et al., 2003; Yepremian et al., 2007), and others could not find any relationship (Jähnichen et al., 2011). Most importantly, however, the results demonstrated that the cell quota varied only within a rather narrow range, that is, by a factor of 2-4 (Table 2.3). In addition to changes in total microcystin cell quota, cultivation factors such as light and nitrogen have also been shown to alter the relative abundance of individual microcystins (Rapala et al., 1997; Tonk et al., 2005; Van de Waal et al., 2009).

More recent work has addressed changes in the microcystin biosynthesis also at the molecular level, but so far without conclusive, comprehensive outcomes. For example, light, iron and nitrogen have been found to either increase or decrease $m c y$ transcription in individual strains, though microcystin cell quota do not necessarily reflect change in transcriptional activity (e.g., Kaebernick et al., 2002; Sevilla et al., 2010; Harke \& Gobler, 2015). 
Table 2.3 Examples of microcystin contents given as mass per dry weight, per biovolume and per cell found in cultured strains

\begin{tabular}{|c|c|c|c|c|c|}
\hline Taxon & Cond. & Origin & $N$ & Range & Reference \\
\hline & \multicolumn{5}{|c|}{$\mathrm{mg} / \mathrm{g} \mathrm{DW}$} \\
\hline Microcystis & $S$ & TW & 6 & $0.3-10$ & Lee et al. (1998) \\
\hline Microcystis & $\mathrm{S}$ & GER & 10 & $<0.1-4$ & Rohrlack et al. (200I) \\
\hline Microcystis & $S$ & JPN & 17 & $0.6-13$ & Watanabe et al. (199I) \\
\hline $\begin{array}{l}\text { Planktothrix } \\
\text { agardhii }\end{array}$ & $S$ & FRA & 36 & $0.02-1.86$ & Yepremian et al. (2007) \\
\hline P. agardhii & $\mathrm{S}$ & Eur, JPN & 18 & I.2-4.5 & Kosol et al. (2009) \\
\hline P. rubescens & $\mathrm{S}$ & Eur, JPN & 31 & $2.9-5.4$ & Kosol et al. (2009) \\
\hline Anabaena a & $S$ & FRA & 2 & $0.35-1.86$ & Vezie et al. (1998) \\
\hline Anabaena ${ }^{a}$ & $\mathrm{~S}$ & FIN & 5 & $1.3-3.9$ & Halinen et al. (2007) \\
\hline Anabaena a & S & EGY & 2 & $3-3.66$ & Mohamed et al. (2006) \\
\hline \multirow[t]{2}{*}{ Anabaena ${ }^{\text {a }}$} & T.L.N.P & FIN & 2 & $<0.3-7$ & Rapala et al. (1997) \\
\hline & \multicolumn{5}{|c|}{$\mu \mathrm{g} / \mathrm{mm}^{3} \mathrm{BV}$} \\
\hline Microcystis & $S$ & KEN & 12 & $0.4-13.8$ & Sitoki et al. (20I2) \\
\hline P. agardhii & $S$ & Eur, JPN & 18 & $2.3-16.7$ & Kosol et al. (2009) \\
\hline P. rubescens & $S$ & Eur,JPN & 31 & I.I-20.6 & Kosol et al. (2009) \\
\hline Microcystis & $\mathrm{L}$ & NLD & 1 & $1.2-2.5$ & Wiedner et al. (2003) \\
\hline Microcystis & L.N.P & DEU & 3 & $0.6-5.0$ & Hesse \& Kohl (200I) \\
\hline \multirow[t]{2}{*}{ P. agardhii } & \multirow[t]{2}{*}{$\mathrm{L}$} & \multirow[t]{2}{*}{ FIN } & \multirow[t]{2}{*}{ I } & $\sim 2-3$ & \multirow[t]{2}{*}{ Tonk et al. (2005) } \\
\hline & & & & $\mathrm{fg} /$ cell & \\
\hline Microcystis & $\mathrm{S}$ & KEN & 12 & $17-553$ & Sitoki et al. (20I2) \\
\hline Microcystis & $P$ & NLD & I & $5-20$ & Ríos et al. (20|4) \\
\hline Microcystis & $P$ & GBR & I & 17-97 & Ríos et al. (20|4) \\
\hline Microcystis & $\mathrm{N}$ & USA & I & $70-220$ & Harke \& Gobler (2013) \\
\hline Microcystis & $\mathrm{L}$ & USA & I & $47-106$ & Deblois \& Juneau (2010) \\
\hline Microcystis & $N$ & AUS & I & $56-165$ & Orr \& Jones (1998) \\
\hline P. agardhii & $S$ & GBR & 2 & $75-91$ & Akçaalan et al. (2006) \\
\hline P. rubescens & $\mathrm{S}$ & GBR & 3 & $104-235$ & Akçaalan et al. (2006) \\
\hline P. agardhii & $\mathrm{S}$ & Eur, JPN & 18 & $44-343$ & Kosol et al. (2009) \\
\hline P. rubescens & S & Eur, JPN & 31 & $\begin{array}{c}27-854 \\
\text { fg/cell }\end{array}$ & Kosol et al. (2009) \\
\hline $\begin{array}{l}\text { Nodularia } \\
\text { spumigena }\end{array}$ & L.N.P & SWE & I & $\sim 100-700$ & Pattanaik et al. (20।0) \\
\hline
\end{tabular}

Cultivation conditions (Cond.) were either one standard (S) or with varying light $(\mathrm{L})$, temperature $(\mathrm{T})$, nitrogen concentration $(\mathrm{N})$ and phosphorus concentration $(\mathrm{P})$. The origin of the analysed strains $(\mathrm{N})$ is given by ISO 3166 country code. Data from some studies have been transformed to units as given here. Note that content in field samples is generally much lower as these consist of a mixture of clones with individual toxin contents ranging from 0 (nonproducers) to 9 (values as reported as maxima in this table; see also section 4.6).

a Reported as Anabaena but possibly Dolichospermum (see Chapter 3). 


\subsubsection{Occurrence in water environments}

Numerous screening programmes conducted during the past 30 years in various parts of the world detected microcystins in $20 \%$ to $100 \%$ of the samples, with frequencies generally correlated with the trophic state of the sampled water bodies (Bigham et al., 2009). In waterbodies containing potentially toxigenic genera such as Microcystis and Planktothrix, microcystins were detected in $80-100 \%$ of the samples (Fastner et al., 2001; Graham et al., 2010; Gkelis \& Zaoutsos, 2014). Thus, any waterbody with these taxa should be assumed to contain microcystins unless analytical results show that this is not the case. In samples dominated by Dolichospermum, microcystins were detected less frequently (Chorus, 2001).

Microcystin-producing genotypes can persist in cyanobacterial populations, and thus may be found during the whole growing season, even yearround. This includes not only tropical waterbodies, but also temperate shallow lakes dominated by Planktothrix agardhii and stratified, deep lakes harbouring Planktothrix rubescens (Pawlik-Skowronska et al., 2008; MankiewiczBoczek et al., 2011; Akçaalan et al., 2014; Cerasino et al., 2016).

Early reports on microcystin found in field samples often expressed values as mg or $\mu$ g per gram dry weight, that is, toxin contents (see box 4.6), most likely due to comparably insensitive methods used at the time and the requirement of large amounts of cell material for toxin analyses. Reported microcystin contents range from a few ng up to - rarely - around 13-15 $\mathrm{mg} / \mathrm{g}$ dry weight (Sivonen \& Jones, 1999). Since the late 1990s, microcystin occurrence has increasingly been reported as concentrations, that is, per volume of water, which is the more relevant unit for cyanotoxin risk assessment.

Average microcystin concentrations in the pelagic water outside scums do not frequently exceed several tens of $\mu \mathrm{g} / \mathrm{L}$ (Fastner et al., 2001; Bláha $\&$ Maršálek, 2003; Carrasco et al., 2006; Nasri et al., 2007; Graham et al., 2010; Sakai et al., 2013; Gkelis \& Zaoutsos, 2014; Chia \& Kwaghe, 2015; Mowe et al., 2015; Su et al., 2015; Beversdorf et al., 2017). However, in surface blooms and scums of Microcystis, microcystin concentrations can be up to several orders of magnitude higher than in the pelagic water, with the reported maximum values up to 20 and $124 \mathrm{mg} / \mathrm{L}$ (Kemp \& John, 2006; Wood et al., 2006; Masango et al., 2010; Waajen et al., 2014).

Planktothrix rubescens forms population maxima in the metalimnetic layer with microcystin concentrations usually of only $<1$ to $10 \mu \mathrm{g} / \mathrm{L}$ (Jacquet et al., 2005; Akçaalan et al., 2014; Cerasino et al., 2016). Following turnover of the waterbody, the formation of surface blooms has been observed with microcystin concentrations attaining up to $34 \mathrm{mg} / \mathrm{L}$ (Naselli-Flores et al., 2007).

Although microcystin concentrations can also reach more than $100 \mu \mathrm{g} / \mathrm{L}$ in blooms of Planktothrix agardhii, this species rarely forms surface bloom or scums (Fastner et al., 2001; Wiedner et al., 2002; Catherine et al., 2008; Pawlik-Skowronska et al., 2008; Mankiewicz-Boczek et al., 2011), and hence, microcystin concentrations $>1 \mathrm{mg} / \mathrm{L}$ have only rarely been observed. 
Nodularins occur frequently in Nodularia spumigena populations from both temperate and subtropical environments with recurrent annual toxic blooms, for example, in the Baltic Sea. As with microcystins, concentrations may be several orders of magnitude higher in surface blooms compared to populations entrained homogeneously in the water column. The nodularin content of such blooms ranged from 3.5 to $18 \mathrm{mg} / \mathrm{g} \mathrm{dw}$, and concentrations from a few $\mu \mathrm{g}$ in the open water up to $18 \mathrm{mg} / \mathrm{L}$ in surface blooms have been reported (Kononen et al., 1993; Heresztyn \& Nicholson, 1997; Mazur \& Plinski, 2003; McGregor et al., 2012; Sahindokuyucu-Kocasari et al., 2015).

Although the variability of microcystin content within individual clones is limited to a factor of 2-4, the microcystin content of field populations of toxigenic taxa may vary by a few orders of magnitude. This suggests that much, if not most, of the variation in toxin content of monospecific natural blooms is attributable to the waxing and waning of clones of the same species, with clones varying in their toxin contents (see Chapter 4; Briand et al., 2008).

\section{I.5.I Bioaccumulation}

Microcystins and nodularins have been detected in common aquatic vertebrates and invertebrates, including fish, mussels, shrimps and zooplankton (Kotak et al., 1996; Freitas de Magalhães et al., 2001; Sipiä et al., 2002; Chen \& Xie, 2005; Xie et al., 2005; Ibelings \& Havens, 2008). Because of the relevance of these findings for food from aquatic environments, bioaccumulation of microcystins/nodularins in biota and its role in health risk assessment are discussed in the section on food (5.3). The effects and possible bioaccumulation of microcystins on plants are reviewed in Machado et al. (2017).

\subsubsection{Environmental fate}

\section{I.6.I Partitioning between cells and water}

Microcystins and nodularins are primarily found in viable cyanobacterial cells. Experiments with radiolabelled microcystin did not show a substantial export of intracellular toxins from cells under high as well as under low light conditions (Rohrlack \& Hyenstrand, 2007). Release to the surrounding water as extracellular (dissolved) toxin is considered to occur mainly during cell senescence, death and lysis.

In laboratory studies, where both intracellular and extracellular microcystins/nodularins have been measured, the general finding was that in healthy cultures, less than $10 \%$ of the total toxin pool is extracellular (Lehtimaki et al., 1997; Rapala et al., 1997; Sivonen \& Jones, 1999; Wiedner et al., 2003; Jähnichen et al., 2007). Even during log-phase cell growth in culture, a small percentage of cells in the population may be lysing and hence release 
intracellular microcystins. As cells enter the stationary phase, the increased rate of cell death may lead to an increase in the extracellular fraction.

Accordingly, in growing field populations, no or only little extracellular microcystin has been found. Concentrations of extracellular microcystins measured in such cases mostly range from not detectable to a few $\mu \mathrm{g} / \mathrm{L}$ and amount to only a small fraction of the cell-bound toxins in the same samples (Pietsch et al., 2002; Wiedner et al., 2002; Welker et al., 2003; Bláhová et al., 2007; Pawlik-Skowronska et al., 2008). While in ageing or declining blooms large amounts of microcystins are liberated from the cells, the actual concentrations in water depend primarily on dilution and other factors such as adsorption and degradation, rarely reach values exceeding $100 \mu \mathrm{g} / \mathrm{L}$ (Welker et al., 2001). The only report of very high extracellular microcystin concentrations, reaching $1800 \mu \mathrm{g} / \mathrm{L}$, was following an algicide treatment of a cyanobacterial bloom leading to sudden and complete lysis and thus a massive release of toxins (Kenefick et al., 1993; Jones \& Orr, 1994).

For the production of drinking-water, special attention to procedures that potentially could release microcystins from cells is important: oxidation with ozone and chlorine, as well as flocculation and filtration, can lead to a leakage of microcystins from the cells (see Chapter 10; Pietsch et al., 2002; Schmidt et al., 2002; Daly et al., 2007).

\subsubsection{Chemical breakdown}

Microcystins are chemically very stable. They remain potent even after boiling for several hours (Harada, 1996) and may persist for many years when stored dry at room temperature (Metcalf et al., 2012). At near-neutral $\mathrm{pH}$, microcystins are resistant to chemical hydrolysis or oxidation. At $40^{\circ} \mathrm{C}$ and at elevated or low $\mathrm{pH}$, slow hydrolysis has been observed, with the times to achieve greater than $90 \%$ breakdown being approximately 10 weeks at pH 1 and greater than 12 weeks at $\mathrm{pH} 9$ (Harada, 1996). Rapid chemical hydrolysis occurs only under conditions that are unlikely to be attained outside the laboratory, for example, $6 \mathrm{M} \mathrm{HCl}$ at high temperature.

Microcystins can be oxidised by ozone and other strong oxidising agents (Rositano et al., 2001; Rodríguez et al., 2007), and degraded by intense ultraviolet (UV) light (Kaya \& Sano, 1998). Several studies have investigated the degradation by, for example, photocatalysis, $\mathrm{H}_{2} \mathrm{O}_{2} / \mathrm{UV}$ light and the photo-Fenton process (He et al., 2012; de Freitas et al., 2013; Pestana et al., 2015). These processes have relevance for water treatment and are discussed in Chapter 10, but are unlikely to contribute to degradation occurring in the natural environment.

In full sunlight, microcystins undergo only slow photochemical breakdown and isomerisation, with the reaction rate being enhanced by the presence of water-soluble cell pigments, presumably phycobiliproteins (Tsuji 
et al., 1994). In the presence of such pigments, the photochemical breakdown of microcystin in full sunlight can take as little as 2 weeks for greater than $90 \%$ breakdown, or longer than 6 weeks, depending on the concentration of pigment (and presumably toxin, although this has not been tested). A more rapid breakdown under sunlight has been reported in the presence of naturally occurring humic substances which can act as photosensitisers. In an experimental study, approximately $40 \%$ of the microcystins was degraded per day under summer conditions of insolation (Welker \& Steinberg, 1999). However, since the penetration of active UV radiation is limited in deeper or turbid waters, the breakdown in situ is likely to be considerably slower (Welker \& Steinberg, 2000). Photosensitised transformation of microcystins has been studied in detail by Song et al. (2007).

The chemical decomposition of nodularin has been studied less intensively; however, their structural similarity suggests similar characteristics as microcystin. Nodularin degradation has also been observed under UV radiation (Mazur-Marzec et al., 2006a).

\section{I.6.3 Biodegradation}

Microcystins are resistant to eukaryotic and many bacterial peptidases (Botes et al., 1982; Falconer et al., 1986; Harada, 1996); however, some human probiotic bacteria have microcystin-decomposing capability (Nybom et al., 2012).

In contrast, microcystins are susceptible to breakdown by a number of aquatic bacteria. These bacteria appear widespread and have been found in sewage effluent, lake water, lake sediment and river water worldwide (Holst et al., 2003; Edwards et al., 2008). MC-degrading bacteria have also been detected in the mucilage of Microcystis colonies (Maruyama et al., 2003). The majority of the microcystin-degrading bacteria isolated to date have been identified as Sphingomonas spp. and Sphingopyxis spp. belonging to the $\alpha$-proteobacteria; further microcystin-degrading bacteria are also found among the ß-proteobacteria (e.g., Pseudomonas aeruginosa), $\gamma$-proteobacteria (e.g., Paucibacter toxinivorans), actinobacteria and bacilli (Edwards et al., 2008; Dziga et al., 2013; Li et al., 2017).

Most of these bacteria perform aerobic degradation of microcystins. The degradation pathway and mir genes encoding for the involved enzymes have been studied in detail in an isolate of Sphingomonas sp. (Bourne et al., 2001). The products of complete bacterial degradation were nontoxic to mice at i.p. doses 10 times higher than the $\mathrm{LD}_{50}$ of microcystin-LR. However, other intermediate breakdown products as well as the lack of mir genes in some MC-degrading bacteria suggest that multiple aerobic degradation pathways may exist (Amé et al., 2006; Edwards et al., 2008; Dziga et al., 2013). This also applies for possible anaerobic biodegradation, which, however, is far less intensively studied, as only a few bacteria showing anaerobic degradation have been isolated to date (Li et al., 2017). 
Degradation of microcystins is often, though not always, characterised by an initial lag phase with little loss of microcystin. This phase was observed in laboratory and field experiments and can last from as little as 2 days to more than several weeks. The duration seems to depend on the previous bloom history of a lake and also on climatic conditions as well as on the concentration of dissolved microcystin (Christoffersen et al., 2002; Hyenstrand et al., 2003; Bourne et al., 2006; Edwards et al., 2008).

Once the biodegradation process commences, the removal of microcystin can be very fast with half-lives of $0.2-5$ days for different microcystins, including MC-RR, MC-YR, MC-LR, MC-LW and MC-LF (Lam et al., 1995; Cousins et al., 1996; Park et al., 2001; Christoffersen et al., 2002; Hyenstrand et al., 2003; Ishii et al., 2004; Babica et al., 2005; Amé et al., 2006; Tsuji et al., 2006; Chen et al., 2008; Edwards et al., 2008). Degradation strongly depends on temperature, but is also influenced by the size of the microbial population and initial microcystin concentration (Park et al., 2001; Bourne et al., 2006). Though a more than $90 \%$ reduction of microcystin has been observed within a few days, low residual microcystin concentration can occasionally still be observed for weeks especially when initial concentrations were high (Jones et al., 1994b; Bourne et al., 2006).

For nodularin, the degradation by microbial activity was demonstrated in marine and freshwater environments (Heresztyn \& Nicholson, 1997; Edwards et al., 2008; Toruńska et al., 2008). The linearisation of nodularin by a Sphingomonas strain was demonstrated suggesting a similar degradation pathway as for microcystins (Imanishi et al., 2005; Kato et al., 2007), and Paucibacter toxinivorans has also been shown to degrade nodularin (Rapala et al., 1997). Other Sphingomonas strains, however, could not degrade nodularin or nodularin-Har, or only in the presence of microcystinRR (Jones et al., 1994a; Ishii et al., 2004).

\section{REFERENCES}

Aboal M, Puig MA (2005). Intracellular and dissolved microcystin in reservoirs of the river Segura basin, Murcia, SE Spain. Toxicon. 45:509-518.

Akçaalan R, Köker L, Gürevin C, Albay M (2014). Planktothrix rubescens: a perennial presence and toxicity in Lake Sapanca. Turkish J Botany. 38:782-789.

Akçaalan R, Mazur-Marzec H, Zalewska A, Albay M (2009). Phenotypic and toxicological characterization of toxic Nodularia spumigena from a freshwater lake in Turkey. Harmful Algae. 8:273-278.

Akçaalan R, Young FM, Metcalf JS, Morrison LF, Albay M, Codd GA (2006). Microcystin analysis in single filaments of Planktothrix spp. in laboratory cultures and environmental samples. Water Res. 40:1583-1590.

Amé MV, Ricardo EJ, Stephan P, Alberto WD (2006). Degradation of microcystinRR by Sphingomonas sp. CBA4 isolated from San Roque reservoir (CórdobaArgentina). Biodegradation. 17:447-455. 
Azevedo SMFO, Evans WR, Carmichael WW, Namikoshi M (1994). First report of microcystins from a Brazilian isolate of the cyanobacterium Microcystis aeruginosa. J Appl Phycol. 6:261-265.

Babica P, Bláha L, Maršálek B (2005). Removal of microcystins by phototrophic biofilms. A microcosm study. Environ Sci Pollut Res. 12:369-374.

Ballot A, Krienitz L, Kotut K, Wiegand C, Pflugmacher S (2005). Cyanobacteria and cyanobacterial toxins in the alkaline crater lakes Sonachi and Simbi, Kenya. Harmful Algae. 4:139-150.

Bateman KP, Thibault P, Douglas DJ, White RL (1995). Mass spectral analysis of microcystins from toxic cyanobacteria using on-line chromatographic and electrophoretic separations. J Chromatogr A. 712:253-268.

Beattie KA, Kaya K, Codd GA (2000). The cyanobacterium Nodularia in PCC 7804, of freshwater origin, produces [L-Har(2)]nodularin. Phytochemistry. 54:57-61.

Bernard C, Ballot A, Thomazeau S, Maloufi S, Furey A, Mankiewicz-Boczek J et al. (2017). Cyanobacteria associated with the production of cyanotoxins. Appendix 2. In: Meriluoto J, Spoof L, Codd GA, editors: Handbook of cyanobacterial monitoring and cyanotoxin analysis. Chichester: John Wiley \& Sons:501-525.

Beversdorf LJ, Weirich CA, Bartlett SL, Miller TR (2017). Variable cyanobacterial toxin and metabolite profiles across six eutrophic lakes of differing physiochemical characteristics. Toxins. 9:62.

Bigham DL, Hoyer MV, Canfield DE (2009). Survey of toxic algal (microcystin) distribution in Florida lakes. Lake Reserv Manage. 25:264-275.

Bláha L, Maršálek B (2003). Contamination of drinking water in the Czech Republic by microcystins. Arch Hydrobiol. 158:421-429.

Bláhová L, Babica P, Maršálková E, Maršálek B, Bláha L (2007). Concentrations and seasonal trends of extracellular microcystins in freshwaters of the Czech Republicresults of the national monitoring program. Soil, Air, Water. 35:348-354.

Bolch CJS, Orr PT, Jones GJ, Blackburn SI (1999). Genetic, morphological, and toxicological variation among globally distributed strains of Nodularia (Cyanobacteria). J Phycol. 35:339-355.

Botes D, Viljoen C, Kruger H, Wessels P, Williams D (1982). Structure of toxins of the blue-green-alga Microcystis aeruginosa. South African J Sci. 78:378-379.

Botes DP, Tuinman AA, Wessels PL, Viljoen CC, Kruger H (1984). The structure of cyanoginosin-LA, a cyclic heptapeptide toxin from the cyanobacterium Microcystis aeruginosa. J Chem Soc Perkin Trans. 1:2311-2318.

Botes DP, Wessels PL, Kruger H, Runnegar MTC, Satikarn S, Smith RJ et al. (1985). Structural studies on cyanoginosins-LR, YR, YA, and YM, peptide toxins from Microcystis aeruginosa. J Chem Soc Perkin Trans. 1:2747-2748.

Bouaïcha N, Miles CO, Beach DG, Labidi Z, Djabri A, Benayache NY et al. (2019). Structural diversity, characterization and toxicology of microcystins. Toxins. 11:714.

Bourne DG, Blakeley RL, Riddles P, Jones GJ (2006). Biodegradation of the cyanobacterial toxin microcystin LR in natural water and biologically active slow sand filters. Water Res. 40:1294-1302.

Bourne DG, Riddles P, Jones GJ, Smith W (2001). Characterisation of a gene cluster involved in bacterial degradation of the cyanobacterial toxin microcystin-LR. Environ Toxicol. 16:523-534.

Briand E, Gugger M, Francois JF, Bernard C, Humbert JF, Quiblier C (2008). Temporal variations in the dynamics of potentially microcystin-producing strains 
in a bloom-forming Planktothrix agardhii (cyanobacterium) population. Appl Environ Microbiol. 74:3839-3848.

Briand JF, Jacquet S, Flinois C, Avois-Jacquet C, Maisonnette C, Leberre B et al. (2005). Variations in the microcystin production of Planktothrix rubescens (Cyanobacteria) assessed from a four-year survey of Lac du Bourget (France) and from laboratory experiments. Microb Ecol. 50:418-428.

Buratti FM, Manganelli M, Vichi S, Stefanelli M, Scardala S, Testai E et al. (2017). Cyanotoxins: producing organisms, occurrence, toxicity, mechanism of action and human health toxicological risk evaluation. Arch Toxicol. 91:1049-1130.

Carmichael WW, Beasley V, Bunner DL, Eloff JN, Falconer IR, Gorham PR et al. (1988). Naming of cyclic heptapeptide toxins of cyanobacteria (blue-green algae). Toxicon 26:971-973.

Carmichael WW, Li RH (2006). Cyanobacteria toxins in the Salton Sea. Saline Syst. 2:5.

Carrasco D, Moreno E, Sanchis D, Wörmer L, Paniagua T, Del Cueto A et al. (2006). Cyanobacterial abundance and microcystin occurrence in Mediterranean water reservoirs in Central Spain: microcystins in the Madrid area. Europ J Phycol. 41:281-291.

Catherine A, Quiblier C, Yepremian C, Got P, Groleau A, Vincon-Leite B et al. (2008). Collapse of a Planktothrix agardhii perennial bloom and microcystin dynamics in response to reduced phosphate concentrations in a temperate lake. FEMS Microbiol Ecol. 65:61-73.

Cerasino L, Shams S, Boscaini A, Salmaso N (2016). Multiannual trend of microcystin production in the toxic cyanobacterium Planktothrix rubescens in Lake Garda (Italy). Chem Ecol. 32:492-506.

Chen J, Xie P (2005). Tissue distributions and seasonal dynamics of the hepatotoxic microcystins-LR and -RR in two freshwater shrimps, Palaemon modestus and Macrobrachium nipponensis, from a large shallow, eutrophic lake of the subtropical China. Toxicon. 45:615-625.

Chen W, Song LR, Peng L, Wan N, Zhang XM, Gan NQ (2008). Reduction in microcystin concentrations in large and shallow lakes: water and sediment-interface contributions. Water Res. 42:763-773.

Chia MA, Kwaghe MJ (2015). Microcystins contamination of surface water supply sources in Zaria-Nigeria. Environ Monit Assess. 187:606.

Chorus I, editors (2001). Cyanotoxins - occurrence, causes, consequences. Berlin: Springer. $357 \mathrm{pp}$.

Christiansen G, Fastner J, Erhard M, Börner T, Dittmann E (2003). Microcystin biosynthesis in Planktothrix: genes, evolution, and manipulation. J Bacteriol. 185:564-572.

Christiansen G, Kurmayer R, Liu Q, Börner T (2006). Transposons inactivate biosynthesis of the nonribosomal peptide microcystin in naturally occurring Planktothrix spp. Appl Environ Microbiol. 72:117-123.

Christiansen G, Molitor C, Philmus B, Kurmayer R (2008). Nontoxic strains of cyanobacteria are the result of major gene deletion events induced by a transposable element. Mol Biol Evol. 25:1695-1704.

Christoffersen K, Lyck S, Winding A (2002). Microbial activity and bacterial community structure during degradation of microcystins. Aquat Microb Ecol. 27:125-136.

Cirés S, Alvarez-Roa C, Wood SA, Puddick J, Loza V, Heimann K (2014). First report of microcystin-producing Fischerella sp. (Stigonematales, Cyanobacteria) in tropical Australia. Toxicon. 88:62-66. 
Cousins IT, Bealing DJ, James HA, Sutton A (1996). Biodegradation of microcystinLR by indigenous mixed bacterial populations. Water Res. 30:481-485.

Cuvin-Aralar ML, Fastner J, Focken U, Becker K, Aralar EV (2002). Microcystins in natural blooms and laboratory cultured Microcystis aeruginosa from Laguna de Bay, Philippines. Syst Appl Microbiol. 25:179-182.

Daly RI, Ho L, Brookes JD (2007). Effect of chlorination on Microcystis aeruginosa cell integrity and subsequent microcystin release and degradation. Environ Sci Technol. 41:4447-4453.

de Freitas AM, Sirtori C, Lenz CA, Zamora PGP (2013). Microcystin-LR degradation by solar photo-Fenton, UV-A/photo-Fenton and UV-C/ $\mathrm{H}_{2} \mathrm{O}_{2}$ : a comparative study. Photochem Photobiol Sci. 12:696-702.

Deblois CP, Juneau P (2010). Relationship between photosynthetic processes and microcystin in Microcystis aeruginosa grown under different photon irradiances. Harmful Algae. 9:18-24.

del Campo FF, Ouahid Y (2010). Identification of microcystins from three collection strains of Microcystis aeruginosa. Environ Pollut. 158:2906-2914.

Diehnelt CW, Dugan NR, Peterman SM, Budde WL (2006). Identification of microcystin toxins from a strain of Microcystis aeruginosa by liquid chromatography introduction into a hybrid linear ion trap-Fourier transform ion cyclotron resonance mass spectrometer. Anal Chem 78:501-512.

Dittmann E, Börner T (2005). Genetic contributions to the risk assessment of microcystin in the environment. Toxicol Appl Pharmacol. 203:192-200.

Dziga D, Wasylewski M, Wladyka B, Nybom S, Meriluoto J (2013). Microbial degradation of microcystins. Chem Res Toxicol. 26:841-852.

Edwards C, Graham D, Fowler N, Lawton LA (2008). Biodegradation of microcystins and nodularin in freshwaters. Chemosphere. 73:1315-1321.

Faassen EJ, Lürling M (2013). Occurrence of the microcystins MC-LW and MC-LF in Dutch surface waters and their contribution to total microcystin toxicity. Mar Drugs. 11:2643-2654.

Falconer IR, Buckley T, Runnegar MT (1986). Biological half-life, organ distribution and excretion of 125I-labelled toxic peptide from the blue-green alga Microcystis aeruginosa. Aust J Biol Sci. 39:17-22.

Fastner J, Erhard M, Carmichael WW, Sun F, Rinehart KL, Rönicke H et al. (1999). Characterization and diversity of microcystins in natural blooms and strains of the genera Microcystis and Planktothrix from German freshwaters. Arch Hydrobiol. 145:147-163.

Fastner J, Wirsing B, Wiedner C, Heinze R, Neumann U, Chorus I (2001). Cyanotoxin occurrence in Germany: microcystins and hepatocyte toxicity. In: Chorus I, editors: Cyanotoxins: occurrence, causes, consequences. Berlin: Springer:22-37.

Fawell JK, James CP, James HA (1994). Toxins from blue-green algae: toxicological assessment of microcystin-LR and a method for its determination in water. Murlow: Foundation for Water Research:46 pp.

Fawell JK, Mitchell RE, Everett DJ, Hill RE (1999). The toxicity of cyanobacterial toxins in the mouse: I Microcystin-LR. Hum Exp Toxicol. 18:162-167.

Fetscher AE, Howard MDA, Stancheva R, Kudela RM, Stein ED, Sutula MA et al. (2015). Wadeable streams as widespread sources of benthic cyanotoxins in California, USA. Harmful Algae. 49:105-116. 
Fewer DP, Tooming-Klunderud A, Jokela J, Wahsten M, Rouhiainen L, Kristensen T et al. (2008). Natural occurrence of microcystin synthetase deletion mutants capable of producing microcystins in strains of the genus Anabaena (Cyanobacteria). Microbiology. 154:1007-1014.

Fewer DP, Wahlsten M, Österholm J, Jokela J, Rouhiainen L, Kaasalainen U et al. (2013). The genetic basis for O-acetylation of the microcystin toxin in cyanobacteria. Chem Biol. 20:861-869.

Freitas de Magalhães V, Soares RM, Azevedo SM (2001). Microcystin contamination in fish from the Jacarepaguá Lagoon (Rio de Janeiro, Brazil): ecological implication and human health risk. Toxicon. 39:1077-1085.

Gehringer MM, Adler L, Roberts AA, Moffitt MC, Mihali TK, Mills TJ et al. (2012). Nodularin, a cyanobacterial toxin, is synthesized in planta by symbiotic Nostoc sp. ISME J. 6:1834.

Gkelis S, Harjunpää V, Lanaras T, Sivonen K (2005). Diversity of hepatotoxic microcystins and bioactive anabaenopeptins in cyanobacterial blooms from Greek freshwaters. Environ Toxicol. 20:249-256.

Gkelis S, Zaoutsos N (2014). Cyanotoxin occurrence and potentially toxin producing cyanobacteria in freshwaters of Greece: a multi-disciplinary approach. Toxicon. 78:1-9.

Graham JL, Loftin KA, Meyer MT, Ziegler AC (2010). Cyanotoxin mixtures and taste-and-odor compounds in cyanobacterial blooms from the midwestern United States. Environ Sci Technol. 44:7361-7368.

Halinen K, Jokela J, Fewer DP, Wahsten M, Sivonen K (2007). Direct evidence for production of microcystins by Anabaena strains from the Baltic sea. Appl Environ Microbiol. 73:6543-6550.

Harada K-I (1996). Chemistry and detection of microcystins. In: Watanabe MF, Harada K-I, Carmichael WW et al., editors: Toxic Microcystis, first edition. Boca Raton (FL): CRC press:103-148.

Harada K-I, Matsuura K, Suzuki M, Watanabe MF, Oishi S, Dahlem AM et al. (1990). Isolation and characterization of the minor components associated with microcystin LR and RR in the cyanobacterium (blue- green-algae). Toxicon. 28:55-64.

Harada K-I, Ogawa K, Kimura Y, Murata H, Suzuki M, Thorn PM et al. (1991a). Microcystins from Anabaena flos-aquae NRC 525-17. Chem Res Toxicol. 4:535-540.

Harada K-I, Ogawa K, Matsuura K, Nagai H, Murata H, Suzuki M et al. (1991b). Isolation of two toxic heptapeptide microcystins from an axenic strain of Microcystis aeruginosa, K-139. Toxicon. 29:479-489.

Harke MJ, Gobler CJ (2013). Global transcriptional responses of the toxic cyanobacterium, Microcystis aeruginosa, to nitrogen stress, phosphorus stress, and growth on organic matter. PLoS One 8:e69834.

Harke MJ, Gobler CJ (2015). Daily transcriptome changes reveal the role of nitrogen in controlling microcystin synthesis and nutrient transport in the toxic cyanobacterium, Microcystis aeruginosa. BMC Genomics. 16:1068.

Harke MJ, Steffen MM, Gobler CJ, Otten TG, Wilhelm SW, Wood SA et al. (2016). A review of the global ecology, genomics, and biogeography of the toxic cyanobacterium, Microcystis spp. Harmful Algae. 54:4-20. 
Haruštiaková D, Welker M (2017). Chemotype diversity in Planktothrix rubescens (cyanobacteria) populations is correlated to lake depth. Environ Microbiol Rep. 9:158-168.

He X, Pelaez M, Westrick JA, O'Shea KE, Hiskia A, Triantis T et al. (2012). Efficient removal of microcystin-LR by UV-C/ $\mathrm{H}_{2} \mathrm{O}_{2}$ in synthetic and natural water samples. Water Res. 46:1501-1510.

Heinze R (1999). Toxicity of the cyanobacterial toxin microcystin-LR to rats after 28 days intake with the drinking water. Environ Toxicol. 14:57-60.

Heresztyn T, Nicholson BC (1997). Nodularin concentrations in Lakes Alexandrina and Albert, South Australia, during a bloom of the cyanobacterium (blue- green alga) Nodularia spumigena and degradation of the toxin. Environ Toxicol Wat Qual. 12:273-282.

Hesse K, Kohl J-G (2001). Effects of light and nutrients supply on growth and microcystin content of different strains of Microcystis aeruginosa. In: Chorus I, editors: Cyanotoxins: occurrence, causes, consequences. Berlin: Springer:104-115.

Hitzfeld BC, Lampert CS, Spaeth N, Mountfort D, Kaspar H, Dietrich DR (2000). Toxin production in cyanobacterial mats from ponds on the McMurdo Ice Shelf, Antarctica. Toxicon. 38:1731-1748.

Holst T, Jørgensen NO, Jørgensen C, Johansen A (2003). Degradation of microcystin in sediments at oxic and anoxic, denitrifying conditions. Water Res. 37:4748-4760.

Hyenstrand P, Rohrlack T, Beattie KA, Metcalf JS, Codd GA, Christoffersen K (2003). Laboratory studies of dissolved radiolabelled microcystin-LR in lake water. Water Res. 37:3299-3306.

IARC (2010). Ingested nitrate and nitrite, and cyanobacterial peptide toxins. Geneva: International Agency for Research on Cancer.

Ibelings BW, Havens KE (2008). Cyanobacterial toxins: a qualitative meta-analysis of concentrations, dosage and effects in freshwater, estuarine and marine biota. In: Hudnell HK, editors: Cyanobacterial harmful algal blooms: state of the science and research needs. New York: Springer:675-732.

Imanishi S, Kato H, Mizuno M, Tsuji K, Harada K-I (2005). Bacterial degradation of microcystins and nodularin. Chem Res Toxicol. 18:591-598.

Ishii H, Nishijima M, Abe T (2004). Characterization of degradation process of cyanobacterial hepatotoxins by a gram-negative aerobic bacterium. Water Res. 38:2667-2676.

Izaguirre G, Jungblut AD, Neilan BA (2007). Benthic cyanobacteria (Oscillatoriaceae) that produce microcystin-LR, isolated from four reservoirs in southern California. Water Res. 41:492-498.

Jacquet S, Briand J-F, Leboulanger C, Avois-Jacquet C, Oberhaus L, Tassin B et al. (2005). The proliferation of the toxic cyanobacterium Planktothrix rubescens following restoration of the largest natural French lake (Lac du Bourget). Harmful Algae. 4:651-672.

Jähnichen S, Ihle T, Petzoldt T, Benndorf J (2007). Impact of inorganic carbon availability on microcystin production by Microcystis aeruginosa PCC 7806. Appl Environ Microbiol. 73:6994-7002.

Jähnichen S, Long BM, Petzoldt T (2011). Microcystin production by Microcystis aeruginosa: direct regulation by multiple environmental factors. Harmful Algae. 12:95-104. 
Jones GJ, Blackburn SI, Parker NS (1994a). A toxic bloom of Nodularia spumigena MERTENS in Orielton Lagoon, Tasmania. Aust J Mar Freshwater Res. 45: 787-800.

Jones GJ, Bourne DG, Blakeley RL, Doelle H (1994b). Degradation of cyanobacterial hepatotoxin microcystin by aquatic bacteria. Nat Toxins. 2:228-235.

Jones GJ, Falconer IR, Wilkins RM (1995). Persistence of cyclic peptide toxins in dried Microcystis aeruginosa crusts from Lake Mokoan, Australia. Environ Toxicol Wat Qual. 10:19-24.

Jones GJ, Orr PT (1994). Release and degradation of microcystin following algicide treatment of a Microcystis aeruginosa bloom in a recreational lake, as determined by HPLC and protein phosphatase inhibition assay. Water Res. 28:871-876.

Jungblut A-D, Hoeger SJ, Mountfort D, Hitzfeld BC, Dietrich DR, Neilan BA (2006). Characterization of microcystin production in an Antarctic cyanobacterial mat community. Toxicon. 47:271-278.

Kaebernick M, Dittmann E, Börner T, Neilan BA (2002). Multiple alternate transcripts direct the biosynthesis of microcystin, a cyanobacterial nonribosomal peptide. Appl Environ Microbiol. 68:449-455.

Kardinaal WEA, Visser PM (2005). Dynamics of cyanobacterial toxins: sources of variability in microcystin concentrations. In: Huisman J, Matthijs HCP, Visser PM, editors: Harmful cyanobacteria. Berlin: Springer:41-63.

Kato H, Imanishi SY, Tsuji K, Harada K-I (2007). Microbial degradation of cyanobacterial cyclic peptides. Water Res. 41:1754-1762.

Kaya K, Sano T (1998). A photodetoxification mechanism of the cyanobacterial hepatotoxin microcystin-LR by ultraviolet irradiation. Chem Res Toxicol. 11:159-163.

Kemp A, John J (2006). Microcystins associated with Microcystis dominated blooms in the southwest wetlands, Western Australia. Environ Toxicol. 21:125-130.

Kenefick SL, Hrudey SE, Peterson HG, Prepas EE (1993). Toxin release from Microcystis aeruginosa after chemical treatment. Wat Sci Technol. 27:433-440.

Kiviranta J, Namikoshi M, Sivonen K, Evans WR, Carmichael WW, Rinehart KL (1992). Structure determination and toxicity of a new microcystin from Microcystis aeruginosa strain 205. Toxicon. 30:1093-1098.

Kleinkauf H, Döhren H (1996). A nonribosomal system of peptide biosynthesis. FEBS J. 236:335-351.

Kononen K, Sivonen K, Lehtimaki J (1993). Toxicity of phytoplankton blooms in the Gulf of Finland and Gulf of Bothnia, Baltic Sea. In: Smayda TJ, Shimizu Y, editors: Toxic phytoplankton blooms in the sea. Amsterdam: Elsevier Scientific Publications:269-274.

Kosol S, Schmidt J, Kurmayer R (2009). Variation in peptide net production and growth among strains of the toxic cyanobacterium Planktothrix spp. Europ J Phycol. 44:49-62.

Kotak BG, Zurawell RW, Prepas EE, Holmes CFB (1996). Microcystin-LR concentration in aquatic food web compartments from lakes of varying trophic status. Can J Fish Aquat Sci. 53:1974-1985.

Kotut K, Ballot A, Krienitz L (2006). Toxic cyanobacteria and their toxins in standing waters of Kenya: implications for water resource use. J Water Health. $4: 233-245$. 
Krishnamurthy T, Carmichael W, Sarver E (1986). Toxic peptides from freshwater cyanobacteria (blue-green algae). I. Isolation, purification and characterization of peptides from Microcystis aeruginosa and Anabaena flos-aquae. Toxicon 24:865-873.

Krishnamurthy T, Szafraniec L, Hunt DF, Shabanowitz J, Yates JR, Hauer CR et al. (1989). Structural characterization of toxic cyclic peptides from blue-green algae by tandem mass spectrometry. Proc Natl Acad Sci USA. 86:770-774.

Kurmayer R, Christiansen G, Fastner J, Börner T (2004). Abundance of active and inactive microcystin genotypes in populations of the toxic cyanobacterium Planktothrix spp. Environ Microbiol. 6:831-841.

Kurmayer R, Christiansen G, Gumpenberger M, Fastner J (2005). Genetic identification of microcystin ecotypes in toxic cyanobacteria of the genus Planktothrix. Microbiology. 151:1525-1533.

Kusumi T, Ooi T, Watanabe MM, Takahashi H, Kakisawa H (1987). Cyanoviridin $\mathrm{RR}$, a toxin from the cyanobacterium (blue-green alga) Microcystis viridis. Tetrahedron Lett. 28:4695-4698.

Lam AKY, Fedorak PM, Prepas EE (1995). Biotransformation of the cyanobacterial hepatotoxin microcystin- LR, as determined by HPLC and protein phosphatase bioassay. Environ Technol. 29:242-246.

Lee TH, Chen YM, Chou HN (1998). First report of microcystins in Taiwan. Toxicon. 36:247-255.

Lehtimaki J, Moisander P, Sivonen K, Kononen K (1997). Growth, nitrogen fixation, and nodularin production by two Baltic sea cyanobacteria. Appl Environ Microbiol. 63:1647-1656.

Lehtimäki J, Sivonen K, Luukkainen R, Niemelä SI (1994). The effects of incubation time, temperature, light, salinity, and phosphorous on growth and hepatotoxin production by Nodularia strains. Arch Hydrobiol. 130:269-282.

Li J, Li R, Li J (2017). Current research scenario for microcystins biodegradation-A review on fundamental knowledge, application prospects and challenges. Sci Tot Environ. 595:615-632.

Lombardo M, Pinto FCR, Vieira JMS, Honda RY, Pimenta AM, Bemquerer MP et al. (2006). Isolation and structural characterization of microcystin-LR and three minor oligopeptides simultaneously produced by Radiocystis feernandoi (Chroococcales, Cyanobacteriae): a Brazilian toxic cyanobacterium. Toxicon. 47:560-566.

Luukkainen R, Namikoshi M, Sivonen K, Rinehart KL, Niemelä SI (1994). Isolation and identification of 12 microcystins from four strains and two bloom samples of Microcystis spp.: structure of a new hepatotoxin. Toxicon. 32: 133-139.

Machado J, Campos A, Vasconcelos V, Freitas M (2017). Effects of microcystin-LR and cylindrospermopsin on plant-soil systems: a review of their relevance for agricultural plant quality and public health. Environ Res. 153:191-204.

Mankiewicz-Boczek J, Gaggała I, Kokociński M, Jurczak T, Stefaniak K (2011). Perennial toxigenic Planktothrix agardhii bloom in selected lakes of Western Poland. Environ Toxicol. 26:10-20.

Maruyama T, Kato K, Yokoyama A, Tanaka T, Hiraishi A, Park H-D (2003). Dynamics of microcystin-degrading bacteria in mucilage of Microcystis. Microb Ecol. 46:279-288. 
Masango MG, Myburgh JG, Labuschagne L, Govender D, Bengis RG, Naicker D (2010). Assessment of Microcystis bloom toxicity associated with wildlife mortality in the Kruger National Park, South Africa. J Wildlife Diseases. 46:95-102.

Mazur H, Plinski M (2003). Nodularia spumigena blooms and the occurrence of hepatotoxin in the Gulf of Gdańsk. Oceanologia. 45:305-316.

Mazur-Marzec H, Meriluoto J, Pliński M (2006a). The degradation of the cyanobacterial hepatotoxin nodularin (NOD) by UV radiation. Chemosphere. 65:1388-1395.

Mazur-Marzec H, Meriluoto J, Plinski M, Szafranek J (2006b). Characterization of nodularin variants in Nodularia spumigena from the Baltic Sea using liquid chromatography/mass spectrometry/mass spectrometry. Rapid Commun Mass Spectrom. 20:2023-2032.

McGregor GB, Sendall BC (2017). Iningainema pulvinus gen nov., sp nov.(Cyanobacteria, Scytonemataceae) a new nodularin producer from Edgbaston Reserve, north-eastern Australia. Harmful Algae. 62:10-19.

McGregor GB, Stewart I, Sendall BC, Sadler R, Reardon K, Carter S et al. (2012). First report of a toxic Nodularia spumigena (Nostocales/Cyanobacteria) bloom in sub-tropical Australia. I. Phycological and public health investigations. Int J Environ Res Public Health. 9:2396-2411.

Meissner S, Fastner J, Dittmann E (2013). Microcystin production revisited: conjugate formation makes a major contribution. Environ Microbiol. 15:1810-1820.

Meriluoto JAO, Sandström A, Eriksson JE, Remaud G, Grey Craig A, Chattopadhyaya $\mathrm{J}$ (1989). Structure and toxicity of a peptide hepatotoxin from the cyanobacterium Oscillatoria agardhii. Toxicon. 27:1021-1034.

Metcalf JS, Richer R, Cox PA, Codd GA (2012). Cyanotoxins in desert environments may present a risk to human health. Sci Tot Environ. 421:118-123.

Moffitt MC, Neilan BA (2004). Characterization of the nodularin synthetase gene cluster and proposed theory of the evolution of cyanobacterial hepatotoxins. Appl Environ Microbiol. 70:6353-6362.

Mohamed ZA, Al Shehri AM (2009). Microcystin-producing blooms of Anabaenopsis arnoldi in a potable mountain lake in Saudi Arabia. FEMS Microbiol Ecol. 69:98-105.

Mohamed ZA, Al Shehri AM (2010). Microcystin production in epiphytic cyanobacteria on submerged macrophytes. Toxicon. 55:1346-1352.

Mohamed ZA, El Sharouny HM, Ali WSM (2006). Microcystin production in benthic mats of cyanobacteria in the Nile River and irrigation canals, Egypt. Toxicon. 47:584-590.

Mowe MA, Mitrovic SM, Lim RP, Furey A, Yeo DC (2015). Tropical cyanobacterial blooms: a review of prevalence, problem taxa, toxins and influencing environmental factors. J Limnol. 74: 205-224.

Namikoshi M, Choi BW, Sakai R, Sun F, Rinehart KL, Evans WR et al. (1994). New nodularins: a general method for structure assignment. J Org Chem. 59:2349-2357.

Namikoshi M, Rinehart KL, Sakai R, Stotts RR, Dahlem AM, Beasley CR et al. (1992a). Identification of 12 hepatotoxins from Homer lake bloom of the cyanobacterium Microcystis aeruginosa, Microcystis viridis, and Microcystis wesenbergii: nine new microcystins. J Org Chem. 57:866-872.

Namikoshi M, Sivonen K, Evans WR, Carmichael WW, Rouhiainen L, Luukkainen R et al. (1992b). Structures of three new homotyrosine-containing microcystins 
and a new homophenylalanine variant from Anabaena sp. strain 66. Chem Res Toxicol. 5:661-666.

Namikoshi M, Sivonen K, Evans WR, Carmichael WW, Sun F, Rouhiainen L et al. (1992c). Two new L-Serine variants of microcystin-LR and -RR from Anabaena sp. strains 202 A1 and 202 A2. Toxicon 30:1457-1464.

Namikoshi M, Sivonen K, Evans WR, Sun F, Carmichael WW, Rinehart KL (1992d). Isolation and structures of microcystins from a cyanobacterial water bloom (Finland). Toxicon. 30:1473-1479.

Naselli-Flores L, Barone R, Chorus I, Kurmayer R (2007). Toxic cyanobacterial blooms in reservoirs under a semiarid mediterranean climate: the magnification of a problem. Environ Toxicol. 22:399-404.

Nasri H, Bouaicha N, Harche MK (2007). A new morphospecies of Microcystis sp. forming bloom in the Cheffia dam (Algeria): seasonal variation of microcystin concentrations in raw water and their removal in a full-scale treatment plant. Environ Toxicol. 22:347-356.

Nguyen LTT, Cronberg G, Annadotter H, Larsen J (2007). Planktic cyanobacteria from freshwater localities in ThuaThien-Hue province, Vietnam. II. Algal biomass and microcystin production. Nova Hedwigia. 85:35-49.

Nybom S, Dziga D, Heikkilä J, Kull T, Salminen S, Meriluoto J (2012). Characterization of microcystin-LR removal process in the presence of probiotic bacteria. Toxicon. 59:171-181.

Oksanen I, Jokela J, Fewer D, Wahlsten M, Rikkinen J, Sivonen K (2004). Discovery of rare and highly toxic microcystins from lichen-associated cyanobacterium Nostoc sp. strain IO-102-I. Appl Environ Microbiol 70:5756-5763.

Orr PT, Jones GJ (1998). Relationship between microcystin production and cell division rates in nitrogen-limited Microcystis aeruginosa cultures. Limnol Oceanogr. 43:1604-1614.

Park HD, Sasaki Y, Maruyama T, Yanagisawa E, Hiraishi A, Kato K (2001). Degradation of the cyanobacterial hepatotoxin microcystin by a new bacterium isolated from a hypertrophic lake. Environ Toxicol. 16:337-343.

Pattanaik B, Wulff A, Roleda MY, Garde K, Mohlin M (2010). Production of the cyanotoxin nodularin - a multifactorial approach. Harmful Algae. 10:30-38.

Pawlik-Skowronska B, Pirszel J, Kornijow R (2008). Spatial and temporal variation in microcystin concentrations during perennial bloom of Planktothrix agardhii in a hypertrophic lake. Ann Limnol. 44:145-150.

Pearson LA, Dittmann E, Mazmouz R, Ongley SE, D’Agostino PM, Neilan BA (2016). The genetics, biosynthesis and regulation of toxic specialized metabolites of cyanobacteria. Harmful Algae. 54:98-111.

Pestana CJ, Edwards C, Prabhu R, Robertson PK, Lawton LA (2015). Photocatalytic degradation of eleven microcystin variants and nodularin by $\mathrm{TiO}_{2}$ coated glass microspheres. J Hazard Mat. 300:347-353.

Pietsch J, Bornmann K, Schmidt W (2002). Relevance of intra-and extracellular cyanotoxins for drinking water treatment. CLEAN-Soil Air Water. 30:7-15.

Prinsep MR, Caplan FR, Moore RE, Patterson GML, Honkanen RE, Boynton AL (1992). Microcystin-LA from a blue-green alga belonging to the Stigonematales. Phytochemistry. 31:4.

Puddick J, Prinsep MR, Wood SA, Kaufononga SA, Cary SC, Hamilton DP (2014). High levels of structural diversity observed in microcystins from Microcystis 
CAWBG11 and characterization of six new microcystin congeners. Mar Drugs. 12:5372-5395.

Quiblier C, Wood SA, Echenique-Subiabre I, Heath M, Villeneuve A, Humbert JF (2013). A review of current knowledge on toxic benthic freshwater cyanobacteriaecology, toxin production and risk management. Water Res. 47:5464-5479.

Rantala A, Fewer D, Hisbergues M, Rouhiainen L, Vaitomaa J, Börner T et al. (2004). Phylogenetic evidence for the early evolution of microcystin synthesis. Proc Natl Acad Sci USA. 101:568-573.

Rapala J, Sivonen K, Lyra C, Niemelä SI (1997). Variation of microcystins, cyanobacterial hepatotoxins, in Anabaena spp. as a function of growth stimuli. Appl Environ Microbiol. 63:2206-2212.

Rinehart KL, Harada K, Namikoshi M, Chen C, Harvis CA, Munro MH et al. (1988). Nodularin, microcystin, and the configuration of Adda. J Am Chem Soc. 110:8557-8558.

Ríos V, Moreno I, Prieto A, Soria-Díaz ME, Frías J, Cameán A (2014). Comparison of Microcystis aeruginosa (PCC7820 and PCC7806) growth and intracellular microcystins content determined by liquid chromatography-mass spectrometry, enzyme-linked immunosorbent assay anti-Adda and phosphatase bioassay. J Water Health. 12:69-80.

Rodríguez E, Onstad GD, Kull TP, Metcalf JS, Acero JL, von Gunten U (2007). Oxidative elimination of cyanotoxins: comparison of ozone, chlorine, chlorine dioxide and permanganate. Water Res. 41:3381-3393.

Rohrlack T, Henning M, Kohl J-G (2001). Isolation and characterization of colonyforming Microcystis aeruginosa strains. In: Chorus I, editors: Cyanotoxins: occurrence, causes, consequences. Berlin: Springer:152-158.

Rohrlack T, Hyenstrand P (2007). Fate of intracellular microcystins in the cyanobacterium Microcystis aeruginosa (Chroococcales, Cyanophyceae). Phycologia. 46:277-283.

Rositano J, Newcombe G, Nicholson B, Sztajnbok P (2001). Ozonation of NOM and algal toxins in four treated waters. Water Res. 35:23-32.

Rouhiainen L, Vakkilainen T, Siemer BL, Buikema W, Haselkorn R, Sivonen K (2004). Genes coding for hepatotoxic heptapeptides (microcystins) in the cyanobacterium Anabaena strain 90. Appl Environ Microbiol. 70:686-692.

Sahindokuyucu-Kocasari F, Gulle I, Kocasari S, Pekkaya S, Mor F (2015). The occurrence and levels of cyanotoxin nodularin from Nodularia spumigena in the alkaline and salty Lake Burdur, Turkey. J Limnol. 74: 530-536.

Sakai H, Hao A, Iseri Y, Wang S, Kuba T, Zhang Z et al. (2013). Occurrence and distribution of microcystins in Lake Taihu, China. Sci World J. 2013:7.

Sano T, Kaya K (1995). A 2-amino-2-butenoic acid (Dhb)-containing microcystin isolated from Oscillatoria agardhii. Tetrahedron Lett. 36:8603-8606.

Sano T, Kaya K (1998). Two new (E)-2-amino-2-butenoic acid (Dhb)-containing microcystins isolated from Oscillatoria agardhii. Tetrahedron. 54:463-470.

Schmidt W, Willmitzer H, Bornmann K, Pietsch J (2002). Production of drinking water from raw water containing cyanobacteria - Pilot plant studies for assessing the risk of microcystin breakthrough. Environ Toxicol. 17:375-385.

Sevilla E, Martin-Luna B, Vela L, Bes MT, Peleato ML, Fillat MF (2010). MicrocystinLR synthesis as response to nitrogen: transcriptional analysis of the $m c y \mathrm{D}$ gene in Microcystis aeruginosa PCC7806. Ecotoxicology. 19:1167-1173. 
Shih PM, Wu D, Latifi A, Axen SD, Fewer DP, Talla E et al. (2013). Improving the coverage of the cyanobacterial phylum using diversity-driven genome sequencing. Proc Natl Acad Sci USA. 110:1053-1058.

Sipiä V, Kankaanpää H, Pflugmacher S, Flinkman J, Furey A, James K (2002). Bioaccumulation and detoxication of nodularin in tissues of flounder (Platichthys flesus), mussels (Mytilus edulis, Dreissena polymorpha), and clams (Macoma balthica) from the northern Baltic Sea. Ecotoxicol Environ Safety. 53:305-311.

Sitoki L, Kurmayer R, Rott E (2012). Spatial variation of phytoplankton composition, biovolume, and resulting microcystin concentrations in the Nyanza Gulf (Lake Victoria, Kenya). Hydrobiologia. 691:109-122.

Sivonen K, Jones GJ (1999). Cyanobacterial toxins. In: Chorus I, Bartram J, editors: Toxic cyanobacteria in water. London: E \& FN Spoon:41-111.

Sivonen K, Kononen K, Carmichael WW, Dahlem AM, Rinehart KL, Kirivanta J et al. (1989). Occurrence of the hepatotoxic cyanobacterium Nodularia spumigena in the Baltic Sea and structure of the toxin. Appl Environ Microbiol. 55:1990-1995.

Sivonen K, Namikoshi M, Evans WR, Carmichael WW, Sun F, Rouhiainen L et al. (1992a). Isolation and characterization of a variety of microcystins from seven strains of the cyanobacterial genus Anabaena. Appl Environ Microbiol. 58: 2495-2500.

Sivonen K, Namikoshi M, Evans WR, Gromov BV, Carmichael WW, Rinehart KL (1992b). Isolation and structures of five microcystins from a Russian Microcystis aeruginosa strain CALU 972. Toxicon. 30:1481-1485.

Sivonen K, Namikoshi M, Luukkainen R, Fardig M, Rouhiainen L, Evans W et al. (1995). Variation of cyanobacterial hepatotoxins in Finland. In: Munawar M, Luotola M, editors: The contaminants in the Nordic ecosystem, dynamics, processes and fate. Amsterdam: SPB Academic Publishing:163-169.

Song W, Bardowell S, O'Shea KE (2007). Mechanistic study and the influence of oxygen on the photosensitized transformations of microcystins (cyanotoxins). Environ Sci Technol. 41:5336-5341.

Spoof L, Catherine A (2017). Table of microcystins and nodularins. In: Meriluoto J, Spoof L, Codd GA et al., editors: Handbook of cyanobacterial monitoring and cyanotoxin analysis. Chichester: John Wiley \& Sons:526-537.

Stoner RD, Adams WH, Slatkin DN, Siegelman HW (1989). The effects of single L-amino acid substitutions on the lethal potencies of the microcystins. Toxicon. 27:825-828.

Su X, Xue Q, Steinman AD, Zhao Y, Xie L (2015). Spatiotemporal dynamics of microcystin variants and relationships with environmental parameters in Lake Taihu, China. Toxins. 7:3224-3244.

Tillett D, Dittmann E, Erhard M, von Döhren H, Börner T, Neilan BA (2000). Structural organization of microcystin biosynthesis in Microcystis aeruginosa PCC7806: an integrated peptide-polyketide synthetase system. Chem Biol. 7:753-764.

Tonk L, Visser PM, Christiansen G, Dittmann E, Snelder EOFM, Wiedner C et al. (2005). The microcystin composition of the cyanobacterium Planktothrix agardhii changes toward a more toxic variant with increasing light intensity. Appl Environ Microbiol. 71:5177-5181.

Tooming-Klunderud A, Mikalsen B, Kristensen T, Jakobsen KS (2008). The mosaic structure of the mcyABC operon in Microcystis. Microbiology. 154:1886-1899. 
Toruńska A, Bolałek J, Pliński M, Mazur-Marzec H (2008). Biodegradation and sorption of nodularin (NOD) in fine-grained sediments. Chemosphere. 70: 2039-2046.

Tsuji K, Asakawa M, Anzai Y, Sumino T, Harada K-I (2006). Degradation of microcystins using immobilized microorganism isolated in an eutrophic lake. Chemosphere. 65:117-124.

Tsuji K, Naito S, Kondo F, Ishikawa N, Watanabe MF, Suzuki M et al. (1994). Stability of microcystins from cyanobacteria: effect of light on decomposition and isomerization. Environ Sci Technol. 28:173-177.

Van de Waal DB, Verspagen JM, Lürling M, Van Donk E, Visser PM, Huisman J (2009). The ecological stoichiometry of toxins produced by harmful cyanobacteria: an experimental test of the carbon-nutrient balance hypothesis. Ecol Lett. 12:1326-1335.

Vasconcelos V (2001). Freshwater cyanobacteria and their toxins in Portugal. In: Chorus I, editors: Cyanotoxins: occurrence, causes, consequences. Berlin: Springer:62-67.

Vezie C, Brient L, Sivonen K, Bertru G, Lefeuvre JC, SalkinojaSalonen M (1998). Variation of microcystin content of cyanobacterial blooms and isolated strains in Lake Grand-Lieu (France). Microb Ecol. 35:126-135.

Via-Ordorika L, Fastner J, Kurmayer R, Hisbergues M, Dittmann E, Komárek J et al. (2004). Distribution of microcystin-producing and non-microcystin-producing Microcystis sp in European freshwater bodies: detection of microcystins and microcystin genes in individual colonies. Syst Appl Microbiol. 27:592-602.

Waajen GW, Faassen EJ, Lürling M (2014). Eutrophic urban ponds suffer from cyanobacterial blooms: Dutch examples. Environ Sci Pollut Res. 21: 9983-9994.

Watanabe MF, Watanabe M, Kato T, Harada K-I, Suzuki M (1991). Composition of cyclic peptide toxins among strains of Microcystis aeruginosa (blue-green algae, cyanobacteria). The Botanical Magazine (Shokubutsu Gaku Zasshi). 104:49-57.

Welker M, Christiansen G, von Döhren H (2004). Diversity of coexisting Planktothrix (Cyanobacteria) chemotypes deduced by mass spectral analysis of microcystins and other oligopeptides. Arch Microbiol. 182:288-298.

Welker M, Steinberg C (1999). Indirect photolysis of cyanotoxins: one possible mechanism for their low persistence. Water Res. 33:1159-1164.

Welker M, Steinberg C (2000). Rates of humic substance photosensitized degradation of microcystin-LR in natural waters. Environ Sci Technol. 34:3415-3419.

Welker M, Steinberg C, Jones GJ (2001). Release and persistence of microcystins in natural waters. In: Chorus I, editors: Cyanotoxins: occurrence, causes, consequences. Berlin: Springer:85-103.

Welker M, von Döhren H, Täuscher H, Steinberg CEW, Erhard M (2003). Toxic Microcystis in shallow lake Müggelsee (Germany) - dynamics, distribution, diversity. Arch Hydrobiol. 157:227-248.

WHO (2003a). Cyanobacterial toxins: Microcystin-LR in Drinking-water. Background document for development of WHO Guidelines for Drinking-water Quality. Geneva: World Health Organization:18 pp. http://www.who.int/water_ sanitation_health/dwq/chemicals/cyanobactoxins.pdf?ua=1

WHO (2003b). Guidelines for safe recreational water environments. Vol. 1: Coastal and fresh waters. Geneva: World Health Organization. https://apps.who.int/ iris/handle/10665/42591 
WHO (2020). Cyanobacterial toxins: Microcystins. Background document for development of WHO Guidelines for Drinking-water Quality and Guidelines for Safe Recreational Water Environments. Geneva: World Health Organization. https://apps.who.int/iris/handle/10665/338066

Wiedner C, Nixdorf B, Heinze R, Wirsing B, Neumann U, Weckesser J (2002). Regulation of cyanobacteria and microcystin dynamics in polymictic shallow lakes. Arch Hydrobiol 155:383-400.

Wiedner C, Visser PM, Fastner J, Metcalf JS, Codd GA, Mur LR (2003). Effects of light on the microcystin content of Microcystis strain PCC 7806. Appl Environ Microbiol. 69:1475-1481.

Wood S, Holland P, Stirling D, Briggs L, Sprosen J, Ruck J et al. (2006). Survey of cyanotoxins in New Zealand water bodies between 2001 and 2004. New Zeal J Mar Freshwater Res. 40:585-597.

Wood SA, Kuhajek JM, de Winton M, Phillips NR (2012). Species composition and cyanotoxin production in periphyton mats from three lakes of varying trophic status. FEMS Microbiol Ecol. 79:312-326.

Xie LQ, Xie P, Guo LG, Li L, Miyabara Y, Park HD (2005). Organ distribution and bioaccumulation of microcystins in freshwater fish at different trophic levels from the eutrophic Lake Chaohu, China. Environ Toxicol. 20:293-300.

Yepremian C, Gugger MF, Briand E, Catherine A, Berger C, Quiblier C et al. (2007). Microcystin ecotypes in a perennial Planktothrix agardhii bloom. Water Res. 41:4446-4456. 


\subsection{CYLINDROSPERMOPSINS}

\section{Andrew Humpage and Jutta Fastner}

The cyanobacterium Raphidiopsis raciborskii (the renaming from Cylindrospermopsis has been widely accepted; see Chapter 3) first came to notice after the poisoning of 138 children and 10 adults on Palm Island, a tropical island off Townsville in central Queensland, Australia (Byth, 1980). Cultures of the organism were found to produce effects in mice similar to those seen in the human victims (Hawkins et al., 1985). The pure toxin - named cylindrospermopsin - was identified in 1992 (Ohtani et al., 1992).

\subsection{Chemical structures}

Cylindrospermopsins (CYNs, Figure 2.2) are alkaloids comprising a tricyclic guanidino moiety linked via a hydroxylated bridging carbon (C7) to uracil (Ohtani et al., 1992). Four structural variants have been identified (Table 2.4): 7-epi-cylindrospermopsin (7-epi-CYN), 7-deoxy-cylindrospermopsin (7deoxy-CYN), 7-deoxy-desulpho-cylindrospermopsin and 7-deoxydesulpho-12-acetylcylindrospermopsin (Norris et al., 1999; Banker et al., 2000; Wimmer et al., 2014). The assignments of the absolute configurations of CYN and 7-epi-CYN have been exchanged, but this has little practical bearing as they are both equally toxic (Banker et al., 2000; White \& Hansen, 2005). Pure CYN is a white powder and is very water soluble. It is stable to boiling and a wide range of $\mathrm{pH}$ (Chiswell et al., 1999).

\subsubsection{Toxicity: mode of action}

The toxic effects of cylindrospermopsin, summarised in the following, are described in detail in the WHO Background Document on Cylindrospermopsins (WHO, 2020); see there for further information and references). Based on available studies, the liver, kidneys and erythrocytes may

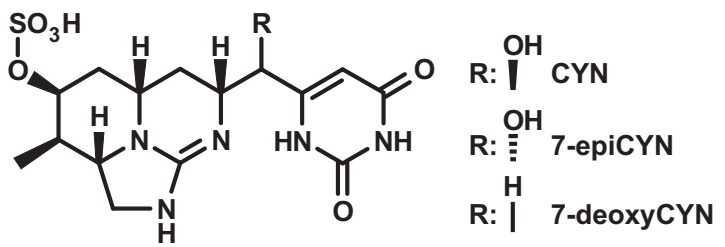

Figure 2.2 Molecular structure of common cylindrospermopsins. 
Table 2.4 Congeners of cylindrospermopsin and their molecular masses

\begin{tabular}{llcc}
\hline Congeners & Formula & $\begin{array}{c}\text { Monoisotopic } \\
\text { molecular mass }(\mathrm{Da})\end{array}$ & $\begin{array}{c}\text { Average molecular } \\
\text { weight (g/mol) }\end{array}$ \\
\hline Cylindrospermopsin & $\mathrm{C}_{15} \mathrm{H}_{21} \mathrm{~N}_{5} \mathrm{O}_{7} \mathrm{~S}$ & 415.116 & 415.428 \\
7-Epi-cylindrospermopsin & $\mathrm{C}_{15} \mathrm{H}_{21} \mathrm{~N}_{5} \mathrm{O}_{7} \mathrm{~S}$ & 415.116 & 415.428 \\
7-Deoxy-cylindrospermopsin & $\mathrm{C}_{15} \mathrm{H}_{21} \mathrm{~N}_{5} \mathrm{O}_{6} \mathrm{~S}$ & 399.121 & 399.429 \\
$\begin{array}{l}\text { 7-Deoxy-desulpho- } \\
\text { cylindrospermopsin }\end{array}$ & $\mathrm{C}_{15} \mathrm{H}_{21} \mathrm{~N}_{5} \mathrm{O}_{3}$ & 319.164 & 319.366 \\
$\begin{array}{l}\text { 7-Deoxy-desulpho-12- } \\
\text { acetylcylindrospermopsin }\end{array}$ & $\mathrm{C}_{17} \mathrm{H}_{23} \mathrm{~N}_{5} \mathrm{O}_{4}$ & 361.175 & 361.404 \\
\hline
\end{tabular}

be important targets of CYN toxicity although studies using radiolabelled CYN suggest that it is distributed to all major organs. Skin patch testing produced only mild skin irritation. Since CYNs are hydrophilic molecules, facilitated transport systems mediate their intestinal absorption and uptake into other cell types, including hepatocytes. However, due to the small size of these molecules, a limited passive diffusion through biological membranes is expected. Although not clearly understood, the specific mechanism for toxicity may involve more than one mode of action, depend on the magnitude and frequency of dose, exposure duration, life stage, age or sex of the organism and the duration that an animal is observed post-dosing. At low concentrations, inhibition of protein synthesis (Terao et al., 1994; Froscio et al., 2003) appears to be the primary effect, which is mediated by the parent compound, whereas at higher exposures, CYN toxicity appears to involve metabolites and other mechanisms that are cytochrome P450-dependent. Reactive oxygen species and induction of stress responses may also be involved in the mode of action.

Cylindrospermopsins have been shown to be genotoxic in various mammalian cells and tissues using both in vitro and in vivo models. The extent and quality of toxicological data on CYN is quite limited, particularly because many studies have used cell extracts rather than pure toxin.

\subsubsection{Derivation of provisional guideline values}

The following section is taken directly from the WHO chemicals background document on cylindrospermopsins (WHO, 2020) which discusses the considerations for the derivation of provisional guideline values for exposure to cylindrospermopsins in more detail. The Point of Departure has been identified as the no observed adverse effect level (NOAEL) of $30 \mu \mathrm{g} / \mathrm{kg}$ bw per day from the Humpage and Falconer (2003) study. By applying an uncertainty factor (UF) of 1000 (100 for inter- and intraspecies variability and 10 for the lack of chronic toxicity studies and deficiencies in the overall toxicological database), a provisional tolerable daily intake TDI (NOAEL/UF) of $0.03 \mu \mathrm{g} / \mathrm{kg}$ bw per day can be derived. The value is provisional because of deficiencies in the CYN toxicological database, essentially related to the 
limited availability of studies with purified toxins, lack of in vivo data on reproductive end-points and the unclear role of metabolites, especially related to potential genotoxicity. The Sukenik et al. (2006) 42-week drinking-water study provides supporting qualitative evidence for CYN toxicity, but the experimental design does not allow derivation of a robust reference value (Funari \& Testai, 2008). The study by Chernoff et al. (2018) observed many of the same effects as seen previously and demonstrates that the NOAEL is below $75 \mu \mathrm{g} / \mathrm{kg}$ bw per day.

The toxicological database is more limited for CYNs than for microcystin-LR - for example, data on on reproductive effects following oral dosing are lacking. Critically, there is evidence for potential in vivo genotoxicity of CYN. However, the lack of chronic dosing studies does not affect derivation of the short-term GV. Therefore, an uncertainty factor of 3 was used to allow for these uncertainties in the derivation of the provisional short-term drinking-water GV and recreational water GV.

For deriving the provisional lifetime drinking-water GV, the fraction of exposure allocated to drinking-water was $80 \%$ because drinking-water is expected to be the most likely long-term source of exposure. For deriving the provisional short-term drinking-water $\mathrm{GV}$, the default allocation factor for short-term values of $100 \%$ was selected, considering that drinking-water is usually the most likely exposure source.

The provisional recreational water GV, which aims to protect from systemic effects, is based on a conservative scenario of a $15-\mathrm{kg}$ child swallowing $250 \mathrm{~mL}$ of water (WHO, 2003).

\section{Calculation of provisional lifetime drinking-water GV for CYN:}

$$
\mathrm{GV}_{\text {chronic }}=\frac{\mathrm{NOAEL}^{*} \mathrm{bw}^{* P}}{\mathrm{UF}^{*} \mathrm{C}}=\frac{30 * 60 * 0.8}{1000 * 2} \mu \mathrm{g} / \mathrm{L}=0.72 \mu \mathrm{g} / \mathrm{L} \approx 0.7 \mu \mathrm{g} / \mathrm{L}
$$

where

$\mathrm{GV}_{\text {chronic }}=\mathrm{GV}$ for chronic (lifetime) exposure

NOAEL $=$ no-observed-adverse-effect level $(30 \mu \mathrm{g} / \mathrm{kg}$ bw per day, based on Humpage \& Falconer, 2003)

bw $=$ body weight (default $=60 \mathrm{~kg}$ for an adult)

$\mathrm{P}=$ fraction of exposure allocated to drinking-water $(80 \%$, because other sources of exposure, such as air, food and soil, are considered minor)

$\mathrm{UF}=$ uncertainty factor $(1000=10$ for interspecies variation $\times 10$ for intraspecies variation $\times 10$ for database deficiencies, including use of a subchronic study)

$\mathrm{C}=$ daily drinking-water consumption (default $=2 \mathrm{~L}$ for an adult $)$. 


\section{Calculation of provisional short-term drinking-water GV for CYN:}

To develop a short-term GV, the same logic was applied except that a UF of

3 was used for database limitations:

$$
\mathrm{GV}_{\text {short-term }}=\frac{\mathrm{NOAEL}_{\text {subchronic }}{ }^{*} \mathrm{bw}^{* P} \mathrm{P}}{\mathrm{UF} * \mathrm{C}}=\frac{30 * 60 * 1.0}{300 * 2} \mu \mathrm{g} / \mathrm{L}=3 \mu \mathrm{g} / \mathrm{L}
$$

where

$\mathrm{GV}_{\text {short-term }}=\mathrm{GV}$ for short-term exposure

NOAEL $=$ no-observed-adverse-effect level $(30 \mu \mathrm{g} / \mathrm{kg}$ bw per day, based on Humpage \& Falconer, 2003)

$\mathrm{bw}=$ body weight $($ default $=60 \mathrm{~kg}$ for an adult $)$

$\mathrm{P}=$ fraction of exposure allocated to drinking-water (default for shortterm exposure $=100 \%$, as drinking-water is expected to be the most likely source of exposure)

$\mathrm{UF}=$ uncertainty factor $(300=10$ for interspecies variation $\times 10$ for intraspecies variation $\times 3$ for database deficiencies)

$\mathrm{C}=$ daily drinking-water consumption (default $=2 \mathrm{~L}$ for an adult).

\section{Calculation of provisional recreational water GV for CYN:}

$$
\mathrm{GV}_{\text {recreation }}=\frac{\mathrm{NOAEL}^{*} \mathrm{bw}}{\mathrm{UF}^{*} \mathrm{C}}=\frac{30 * 15}{300 * 0.25} \mu \mathrm{g} / \mathrm{L}=6 \mu \mathrm{g} / \mathrm{L}
$$

where

$\mathrm{GV}_{\text {recreation }}=\mathrm{GV}$ for recreational water exposure

NOAEL $=$ no-observed-adverse-effect level $(30 \mu \mathrm{g} / \mathrm{kg}$ bw per day, based on Humpage \& Falconer, 2003)

bw $=$ body weight $($ default $=15 \mathrm{~kg}$ for a child $)$

UF $=$ uncertainty factor $(300=10$ for interspecies variation $\times 10$ for intraspecies variation $\times 3$ for database deficiencies)

$\mathrm{C}=$ daily incidental water consumption (default $=250 \mathrm{~mL}$ for a child).

\section{Considerations in applying the provisional guideline values}

The provisional GVs are based on toxicological data for CYN. The limited evidence on the relative potency of other CYN congeners suggests they are probably similar in potency to CYN. Therefore, for assessing risk, as a 
conservative approach, it is suggested that the sum of of CYNs (on a molar basis), be evaluated against the GV.

In some regions, others sources of exposure besides drinking-water can be significant (see chapter 5). This includes food from locations where blooms have a long duration and there is high consumption of locally affected food items. In such situations, it may be appropriate to consider reducing the allocation factor for the lifetime and short-term drinking-water GVs based on relative exposure data for the population.

The short-term drinking-water GV is based on exposure of adults. Since infants and children can ingest a significantly larger volume of water per body weight (e.g., up to 5 times more drinking-water $/ \mathrm{kg}$ bw for bottle-fed infants than for adults), it is recommended that alternative water sources such as bottled water are provided for bottle-fed infants and small children when CYN concentrations are greater than $0.7 \mu \mathrm{g} / \mathrm{L}$ even for short periods, as a precautionary measure.

\subsubsection{Production}

\subsubsection{Producing cyanobacteria}

Cylindrospermopsins (CYNs) have been found in species of Nostocales and Oscillatoriales. Among the Nostocales, Raphidiopsis (Cylindrospermopsis) raciborskii, $R$. curvata, $R$. mediterranea, Chrysosporum (Aphanizomenon) ovalisporum, Chrysosporum (Anabaena) bergii, Aphanizomenon flosaquae, Aphanizomenon gracile and Anabaena lapponica, have been identified as producers (Hawkins et al., 1985; Banker et al., 1997; Li et al., 2001a; Schembri et al., 2001; Preussel et al., 2006; Spoof et al., 2006; McGregor et al., 2011; Kokociński et al., 2013). Umezakia natans, a CYN producer from Japan, was originally assigned to the order Stigonematales (Harada et al., 1994), but later genetic analysis suggests that this species belongs to the Nostocales (Niiyama et al., 2011). Cylindrospermopsin producers belonging to the Oscillatoriales are the benthic Microseira (Lyngbya) wollei, benthic Oscillatoria (Seifert et al., 2007; Mazmouz et al., 2010), as well as Hormoscilla pringsheimii (Bohunická et al., 2015). Producing and nonproducing strains exist within these species.

The CYN-producing species have different regional distribution (de la Cruz et al., 2013). So far only Raphidiopsis raciborskii from Australia, New Zealand and Asia have been found to produce CYNs (Saker \& Griffiths, 2000; Li et al., 2001b; Wood \& Stirling, 2003; Chonudomkul et al., 2004; Nguyen et al., 2017), while none of the $R$. raciborskii strains from North and South America, Africa as well as from Europe have been found to synthesise CYNs (Bernard et al., 2003; Fastner et al., 2003; Saker et al., 2003; Berger et al., 2006; Yilmaz et al., 2008; Fathalli et al., 2011; Hoff-Risseti et al., 2013). CYN-producing C. ovalisporum have been reported from strains and/or field samples of Australia, Florida, Turkey, Israel and Spain (Banker et al., 1997; 
Quesada et al., 2006; Yilmaz et al., 2008; Akçaalan et al., 2014). In middle and northern Europe, CYN occurrence is largely attributed to the presence of Aphanizomenon sp. and Dolichospermum spp. (Preussel et al., 2006; Rücker et al., 2007; Bláhová et al., 2009; Brient et al., 2009; Kokociński et al., 2013).

\subsubsection{Cylindrospermopsin profiles}

While earlier studies focused primarily on CYN, data on the presence of 7-deoxy-CYN and 7-epi-CYN are increasingly reported. It appears that strains may contain varying shares of CYN, 7-deoxy-CYN and 7-epi-CYN. In strains and blooms of $R$. raciborskii, as well as strains of Aphanizomenon and Ana. lapponica, ratios of CYN to 7-deoxy-CYN vary between 0.2 and 5 (Spoof et al., 2006; Orr et al., 2010; Preussel et al., 2014; Willis et al., 2015). In Microseira (Lyngbya) wollei and Raphidiopsis curvata, 7-deoxyCYN has been predominately found (Li et al., 2001a; Seifert et al., 2007). However, growth conditions may alter the ratio of 7-deoxy-CYN to CYN, most probably due to the fact that 7-deoxy-CYN is a precursor of CYN (Mazmouz et al., 2010). 7-Epi-CYN has been detected in C. ovalisporum as a minor compound, whereas it was up to threefold more abundant than CYN in some Oscillatoria strains (Banker et al., 2000; Mazmouz et al., 2010). No information is available on the distribution and concentration of 7-deoxy-desulpho-cylindrospermopsin and 7-deoxy-desulpho12 -acetylcylindrospermopsin recently found (in addition to CYN) in a Thai strain of $R$. raciborskii (Wimmer et al., 2014).

\subsubsection{Biosynthesis}

The complete gene cluster (cyr) for the synthesis of CYN was first sequenced from $R$. raciborskii (Mihali et al., 2008). It spans $43 \mathrm{~kb}$ and encodes 15 open reading frames (ORF). The biosynthesis starts with an amidinotransferase and is completed by nonribosomal peptide/polyketide synthetases and tailoring enzymes. Furthermore, the cluster encodes for a putative transporter (cyrK) for the export of CYN from the cells (Mihali et al., 2008). A putative $\mathrm{NtcA}$ (global nitrogen regulator) binding site has been identified within the cyr cluster, suggesting that CYN synthesis is influenced by $\mathrm{N}$ metabolism (Mazmouz et al., 2011; Stucken et al., 2014).

Since then, homologous clusters or parts of them have been sequenced from further $R$. raciborskii strains (Stucken et al., 2010; Sinha et al., 2014), C. ovalisporum (aoa, gene cluster; Shalev-Alon et al. (2002), Aphanizomenon sp. (Stüken \& Jakobsen, 2010), Oscillatoria sp. (Mazmouz et al., 2010) and Raphidiopsis sp. (Jiang et al., 2014; Pearson et al., 2016). Differences within the gene cluster between strains comprise the order of the cyr genes, flanking genes as well as a sporadic lack of $c y r N$ and $c y r O$ (Jiang et al., 2014; Pearson et al., 2016). 


\subsubsection{Regulation of biosynthesis}

Similar to microcystins, strains differ in the amount of cylindrospermopsins (CYN, 7-epi-CYN and 7-deoxy-CYN) produced, and contents per biomass are in the same range as those of microcystins (Table 2.5). Contents of cylindrospermopsins (CYNs) of some $10 \mu \mathrm{g}$ up to $9.3 \mathrm{mg} / \mathrm{g}$ DW were reported across all producing species (see above) and geographical regions (Saker \& Griffiths, 2000; Preussel et al., 2006; Seifert et al., 2007; Yilmaz et al., 2008; Akçaalan et al., 2014; Cirés et al., 2014; McGregor \& Sendall, 2015). Cell quota of CYNs for $R$. raciborskii strains range from $\sim 3$ to 279 $\mathrm{fg} / \mathrm{cell}$ (Hawkins et al., 2001; Davis et al., 2014; Willis et al., 2016; Yang et al., 2018), and from 49 to $190 \mathrm{fg} / \mathrm{cell}$ in C. ovalisporum (Cirés et al., 2014). Values per unit biovolume are between 0.6 and $3.5 \mu \mathrm{g} \mathrm{CYN} / \mathrm{mm}^{3}$ in

Table 2.5 Examples of cylindrospermopsin contents (not differentiated by congeners, i.e., CYN, 7-epi-CYN and 7-deoxy-CYN) given as mass per dry weight, per biovolume and per cell found in cultured strains

\begin{tabular}{|c|c|c|c|c|c|}
\hline Taxon $^{a}$ & Cond. & Origin & $N$ & Range & Reference \\
\hline & \multicolumn{5}{|c|}{$\mathrm{mg} / \mathrm{g} \mathrm{DW}$} \\
\hline Aphanizomenion sp. & S & DEU & 3 & $2.3-6.6$ & Preussel et al. (2006) \\
\hline $\begin{array}{l}\text { Chrysosporum } \\
\text { ovalisporum }\end{array}$ & $S$ & USA & I & $7.4-9.3$ & Yilmaz et al. (2008) b \\
\hline C. ovalisporum & S & ESP & 6 & $5.7-9.1$ & Cirés et al. (20|4) \\
\hline Raphidiopsis raciborskii & \multicolumn{4}{|r|}{$\mu \mathrm{g} / \mathrm{mm}^{3} \mathrm{BV}$} & Saker \& Griffiths (2000) b \\
\hline C. ovalisporum & $S$ & ESP & 6 & $0.9-2.4$ & Cirés et al. (2014) \\
\hline R. raciborskii & $\mathrm{S}$ & AUS & 2 & $\sim 1-3.5$ & Saker \& Griffiths (2000) b \\
\hline Aphanizomenion sp. & $\mathrm{L}, \mathrm{T}, \mathrm{N}$ & DEU & 3 & $\begin{array}{c}0.3-\mathrm{I} .6 \\
\mathrm{fg} / \mathrm{cell}\end{array}$ & Preussel et al. (2009) \\
\hline C. ovalisporum & $S$ & ESP & 6 & $49-190$ & Cirés et al. (2014) \\
\hline R. raciborskii & $S$ & AUS & 24 & $91-279$ & Willis et al. (2016) b \\
\hline R. raciborskii & $S$ & AUS & 2 & $\sim 10-25$ & Davis et al. (2014) b \\
\hline R. raciborskii & $N$ & $\mathrm{CHN}$ & I & $45-64$ & Yang et al. (20I8) \\
\hline Oscillatoria sp. ${ }^{c}$ & $\mathrm{~L}$ & & 1 & $\sim 3-18$ & Bormans et al. (20|4) \\
\hline
\end{tabular}

Cultivation conditions (Cond.) were either one standard (S), or with varying light (L), temperature ( $T$ ), nitrogen concentration $(\mathrm{N})$ and phosphorus concentration $(\mathrm{P})$. The origin of the analysed strains $(\mathrm{N})$ is given by ISO 3166 country code. Data from some studies have been transformed to units as given here. Note that content in field samples is generally much lower, as these consist of a mixture of clones with individual toxin contents ranging from 0 (nonproducers) to values as reported as maxima in this table; see also section 4.6.

a The taxon given here may deviate from that given in the publication. For changes in taxonomy, see Chapter 3.

b Intracellular CYNs only.

c Benthic form. 
R. raciborskii (Saker \& Griffiths, 2000; Hawkins et al., 2001), 0.3 and 1.6 $\mu \mathrm{g}$ CYNs $/ \mathrm{mm}^{3}$ in Aphanizomenon sp. (Preussel et al., 2009; Preussel et al., 2014) and 0.9 and $2.4 \mu \mathrm{g} \mathrm{CYN} / \mathrm{mm}^{3}$ in C. ovalisporum (Cirés et al., 2014).

Several studies have investigated the influence of environmental factors on CYN production. Though all of the studies showed an effect on CYN content, no consistent pattern in the regulation of the CYN content emerged. The inconsistencies can partly be explained by differences with respect to culture conditions (i.e., batch and semicontinuous), the biomass proxy to which the toxin content was related (i.e., dry weight, biovolume, cell number, or chlorophyll-a) as well as by different reactions of individual strains to the same parameter. A direct linear relationship between total cell quota and growth has been observed in several $R$. raciborskii strains during log phase growth under different light, nutrients and $\mathrm{CO}_{2}$ conditions with cell quota changing maximally by a factor 2-4 (Hawkins et al., 2001; Davis et al., 2014; Pierangelini et al., 2015; Willis et al., 2015; Yang et al., 2018). This observation in combination with a constant expression of cyr genes led to the conclusion that CYN production is constitutive (Davis et al., 2014; Pierangelini et al., 2015; Willis et al., 2015; Yang et al., 2018). However, CYN cell quota decreased substantially ( $>25$-fold) down to nondetectable levels in $R$. raciborskii and to trace levels in C. ovalisporum at $35^{\circ} \mathrm{C}$ (Saker $\&$ Griffiths, 2000; Cirés et al., 2011). This suggests that CYN production may not be constitutive, though this requires further confirmation by following $c y r$ transcript levels. Up to $25-30^{\circ} \mathrm{C}$, the influence of temperature on CYN cell quota was moderate ( 1.5-2.5-fold) in Aphanizomenon sp. and C. ovalisporum (Preussel et al., 2009; Cirés et al., 2011). Changes in cell quota between three- and eightfold were found in relation to light in Oscillatoria PCC 6506 and Chr. ovalisporum and in relation to nutrients in Aphanizomenon sp. and C. ovalisporum (Bar-Yosef et al., 2010; Cirés et al., 2011; Bormans et al., 2014; Preussel et al., 2014).

Environmental conditions also influence the ratio of 7-deoxy-CYN to CYN. For both $R$. raciborskii and Aphanizomenon spp., 7-deoxy-CYN content increased with increasing cell densities under normal growth conditions, while it did not increase or decrease under $\mathrm{N}$-deprived conditions (Davis et al., 2014; Preussel et al., 2014; Stucken et al., 2014).

In contrast to microcystins, a substantial share of cylindrospermopsins is usually and constantly extracellular. In R. raciborskii and Aphanizomenon sp., up to $20 \%$ and in C. ovalisporum up to $40 \%$ of the total CYNs were extracellular during log-phase growth (Hawkins et al., 2001; Cirés et al., 2014; Davis et al., 2014; Preussel et al., 2014), while in Oscillatoria PCC 6505 the extracellular CYNs constantly amounted to more than $50 \%$ (Bormans et al., 2014). Furthermore, the extracellular CYNs increased by up to more than twofold in all species during the stationary phase under different treatments (Saker \& Griffiths, 2000; Hawkins et al., 2001; 
Bormans et al., 2014; Davis et al., 2014). Preussel et al. (2014) found indication of an active release of CYNs under normal growth conditions and showed that the extracellular CYNs did not increase in N-deprived cultures of Aphanizomenon.

For water management, it is important that environmental conditions may not only change the cell quota of CYNs, but also change the share of extracellular CYNs (see Box 5.1) as well as the ratio of 7-deoxy-CYN to CYN. Furthermore, it appears that alterations in nutrient concentrations can change strain composition and thus CYN concentrations in the field (Burford et al., 2014).

\subsubsection{Occurrence in water environments}

Cylindrospermopsins are found globally as a result of the worldwide distribution of producing cyanobacteria, including Raphidiopsis raciborskii, Chrysosporum ovalisporum and Aphanizomenon sp. (Kinnear, 2010; de la Cruz et al., 2013). In Australia, R. raciborskii and C. ovalisporum are the most abundant CYN producers with a high bloom frequency, though the correlation between CYNs concentration and biovolume is generally weak. Concentrations reported often range between $<1$ and $10 \mu \mathrm{g} / \mathrm{L}$, occasional up to maximally $800 \mu \mathrm{g} / \mathrm{L}$ (Chiswell et al., 1999; Shaw et al., 1999; McGregor \& Fabbro, 2000; Shaw et al., 2002). Also in the Mediterranean region and in Florida, CYN occurrence has been often, though not always, associated with C. ovalisporum. Concentrations in these regions were from below $10 \mu \mathrm{g} / \mathrm{L}$ up to maximally $202 \mu \mathrm{g} / \mathrm{L}$ (Quesada et al., 2006; Messineo et al., 2010; de la Cruz et al., 2013; Fadel et al., 2014; Moreira et al., 2017). CYN concentrations reported from more temperate regions of Northern America and Europe are often well below $10 \mu \mathrm{g} / \mathrm{L}$ with a maximal concentration of

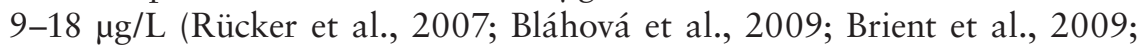
Graham et al., 2010; Kokociński et al., 2013). The highest CYN concentrations (up to almost $3 \mathrm{mg} / \mathrm{L}$ ) were reported from Brazil, although these ELISA data need to be confirmed by LC-MS/MS (Bittencourt-Oliveira et al., 2014; Metcalf et al., 2017).

High concentrations in the range of $10-100 \mathrm{mg} / \mathrm{L}$, as observed for microcystins, have not yet been observed for CYNs, most probably due to the fact that CYN-producing species do not accumulate to very high cell densities, in contrast to scums of the abundant microcystin producer Microcystis sp., for example. Furthermore, up to $90 \%$ of CYN can occur extracellularly in natural waters; outside of scum areas this is then readily diluted by the surrounding water (Rücker et al., 2007).

For water management, it is also important to note that both CYN and 7-deoxy-CYN can be distributed throughout the entire water column with high concentrations also in the hypolimnion (Everson et al., 2011). 


\subsubsection{Bioaccumulation}

Bioaccumulation of CYN in (in)vertebrates and plants has been addressed in several studies. The freshwater mussel Anodonta cygnea has been shown to accumulate, but partially also depurate, CYN (Saker et al., 2004). Both CYN and deoxy-CYN have been found to bioconcentrate and bioaccumulate up to a factor of 124 in whole aquatic snails; however, the alimentary tract was not separated prior to analysis (White et al., 2006). Saker and Eaglesham (1999) found $4.3 \mu \mathrm{g} / \mathrm{g}$ DW of CYN in the hepatopancreas of crayfish and 1.2 $\mu \mathrm{g} / \mathrm{g} \mathrm{DW}$ in fish, suggesting a bioaccumulation factor of 2 . In contrast, several studies detected no free CYN, probably due to binding of CYN to proteins (Esterhuizen-Londt \& Pflugmacher, 2016). As reviewed by Kinnear (2010), biodilution of CYN is likely to occur at higher trophic levels.

Cylindrospermopsin uptake in plants has been found for several crops at environmentally relevant concentrations of $\sim 10-50 \mu \mathrm{g} / \mathrm{L}$ (Kittler et al., 2012; Cordeiro-Araújo et al., 2017; Díez-Quijada et al., 2018; Prieto et al., 2018). While these studies do not indicate substantial bioaccumulation, however, long exposure time with high concentrations of CYN resulted in elevated CYN contents in crops, suggesting their consumption may lead to exceedance of the TDI for CYN (Díez-Quijada et al., 2018). If plants are irrigated with CYN-containing water, assessing potential human exposure through food may require analysing concentrations in crops (see also section 5.3).

More detailed information on bioaccumulation is given in the reviews of Kinnear (2010), de la Cruz et al. (2013) and Machado et al. (2017).

\subsubsection{Environmental fate}

\subsubsection{Partitioning between cells and water}

The results described above show that cylindrospermopsins may readily leach or be released from intact, viable cells under normal growth conditions and that leakage/release increases greatly when the cells enter the stationary growth phase (Dyble et al., 2006; Bormans et al., 2014; Preussel et al., 2014). CYN leakage/release has also been observed in persistent water blooms of both R. raciborskii and Aph. ovalisporum, with up to $100 \%$ of the total toxin in the water found in the extracellular (dissolved) fraction (Chiswell et al., 1999; Shaw et al., 1999). This is also observed in temperate lakes with Aphanizomenon sp. as most probable toxin producer. Where extracellular CYN was detectable, it amounted between $24 \%$ and $99 \%$ of total CYN (Rücker et al., 2007).

\subsubsection{Chemical breakdown}

Cylindrospermopsin appears to be stable over a wide range of temperatures and $\mathrm{pH}$, whereas only higher temperatures $\left(>50^{\circ} \mathrm{C}\right)$ in combination with 
alkaline conditions lead to slow degradation (Chiswell et al., 1999; Adamski et al., 2016). It is also relatively stable in the dark and in sunlight, though in sunlight in the presence of cell pigments, breakdown occurs relatively rapidly, being more than $90 \%$ complete within 23 days (Chiswell et al., 1999; Wörmer et al., 2010). No data on the stability of 7-epi-CYN and 7-deoxyCYN apparently exist.

\subsubsection{Biodegradation}

Biodegradation of $\mathrm{CYN}$ has been observed for some natural waters (Chiswell et al., 1999; Smith et al., 2008), while for others no biodegradation of CYN was found (Wörmer et al., 2008; Klitzke et al., 2010). This can lead to substantial concentrations of dissolved CYN even weeks or months after the producing organisms have declined (Chiswell et al., 1999; Wiedner et al., 2008). Wörmer et al. (2008) also showed that the previous presence of CYN-producing cyanobacteria may not necessarily lead to CYN biodegradation in a waterbody.

Cylindrospermopsin biodegradation studied with natural bacterial consortia either from lakes or from sediments usually showed a lag phase of 1-3 weeks before biodegradation started (Smith et al., 2008; Klitzke et al., 2010). Repeated dosing of CYN eliminated or substantially shortened the lag phase. Once biodegradation had started, the half-lives reported for mixed consortia from water and sediment were 2-4 days (Smith et al., 2008; Klitzke et al., 2010). Similar half-lives were found for a CYN-degrading Bacillus strain which also degraded microcystins (Mohamed \& Alamri, 2012), while CYN half-lives in the presence of an Aeromonas sp. strain were 6-8 days (Dziga et al., 2016). For both natural bacterial consortia and isolated strains, it has been found that biodegradation is strongest between $20^{\circ} \mathrm{C}$ and $35^{\circ} \mathrm{C}$ and at pH between 7 and 8 (Smith et al., 2008; Klitzke \& Fastner, 2012; Mohamed \& Alamri, 2012; Dziga et al., 2016). The biodegradation rate is also strongly influenced by the initial CYN concentration with hardly any CYN biodegradation at concentrations below $1 \mu \mathrm{g} / \mathrm{L}$ (Smith et al., 2008; Mohamed \& Alamri, 2012; Dziga et al., 2016). Removal of dissolved CYN from water samples was also observed with probiotic bacteria (Bifidobacterium longum 46 ) with an efficiency of $31 \%$ CYN removal within $24 \mathrm{~h}$ at $37^{\circ} \mathrm{C}$ (Nybom et al., 2008). Degradation of CYN through the activity of manganeseoxidising bacteria - a polyphyletic type of bacteria common in freshwater, for example, Pseudomonas sp., Ideonella sp. - has been observed (MartínezRuiz et al., 2020b). The transformation products showed reduced toxicity to hepatocytes (Martínez-Ruiz et al., 2020a). No studies on the biodegradation of 7-deoxy-CYN and 7-epi-CYN appear to exist.

For water management, it is important to keep in mind that due to the occasionally poor degradation of CYN in surface water, considerable amounts of 
CYN may still be present when populations of the producing cyanobacteria have already declined or practically disappeared (see Box 5.1 for an example).

\section{REFERENCES}

Adamski M, Żmudzki P, Chrapusta E, Bober B, Kaminski A, Zabaglo K et al. (2016). Effect of $\mathrm{pH}$ and temperature on the stability of cylindrospermopsin. Characterization of decomposition products. Algal Res. 15:129-134.

Akçaalan R, Köker L, Oğuz A, Spoof L, Meriluoto J, Albay M (2014). First report of cylindrospermopsin production by two cyanobacteria (Dolichospermum mendotae and Chrysosporum ovalisporum) in Lake Iznik, Turkey. Toxins. 6:3173-3186.

Banker R, Carmeli S, Hadas O, Teltsch B, Porat R, Sukenik A (1997). Identification of cylindrospermopsin in Aphanizomenon ovalisporum (Cyanophyceae) isolated from lake Kinneret. J Phycol. 33:613-616.

Banker R, Teltsch B, Sukenik A, Carmeli S (2000). 7-epicyclindrospermopsin, a toxic minor metabolite of the cyanobacterium Aphanizomenon ovalisporum from lake Kinneret, Israel. J Nat Prod. 63:387-389.

Bar-Yosef Y, Sukenik A, Hadas O, Viner-Mozzini Y, Kaplan A (2010). Enslavement in the water body by toxic Aphanizomenon ovalisporum, inducing alkaline phosphatase in phytoplanktons. Curr Biol. 20:1557-1561.

Berger C, Ba N, Gugger M, Bouvy M, Rusconi F, Coute A et al. (2006). Seasonal dynamics and toxicity of Cylindrospermopsis raciborskii in Lake Guiers (Senegal, West Africa). FEMS Microbiol Ecol. 57:355-366.

Bernard C, Harvey M, Briand J, Biré R, Krys S, Fontaine J (2003). Toxicological comparison of diverse Cylindrospermopsis raciborskii strains: evidence of liver damage caused by a French C. raciborskii strain. Environ Toxicol. 18:176-186.

Bittencourt-Oliveira MdC, Piccin-Santos V, Moura AN, Aaragao-Tavares NKC, Cordeiro-Araújo MK (2014). Cyanobacteria, microcystins and cylindrospermopsin in public drinking supply reservoirs of Brazil. Anais da Academia Brasileira de Ciências. 86:297-310.

Bláhová L, Oravec M, Maršálek B, Šejnohová L, Šimek Z, Bláha L (2009). The first occurrence of the cyanobacterial alkaloid toxin cylindrospermopsin in the Czech Republic as determined by immunochemical and LC/MS methods. Toxicon. 53:519-524.

Bohunická M, Mareš J, Hrouzek P, Urajová P, Lukeš M, Šmarda J et al. (2015). A combined morphological, ultrastructural, molecular, and biochemical study of the peculiar family Gomontiellaceae (Oscillatoriales) reveals a new cylindrospermopsin-producing clade of cyanobacteria. J Phycol. 51:1040-1054.

Bormans M, Lengronne M, Brient L, Duval C (2014). Cylindrospermopsin accumulation and release by the benthic cyanobacterium Oscillatoria sp. PCC 6506 under different light conditions and growth phases. Bull Environ Contam Toxicol. 92:243-247.

Brient L, Lengronne M, Bormans M, Fastner J (2009). First Occurrence of Cylindrospermopsin in Freshwater in France. Environ Toxicol. 24:415-420.

Burford MA, Davis TW, Orr PT, Sinha R, Willis A, Neilan BA (2014). Nutrientrelated changes in the toxicity of field blooms of the cyanobacterium, Cylindrospermopsis raciborskii. FEMS Microbiol Ecol. 89:135-148. 
Byth S (1980). Palm Island mystery disease. Med J Aust. 2:40-42.

Chernoff N, Hill D, Chorus I, Diggs D, Huang H, King D et al. (2018). Cylindrospermopsin toxicity in mice following a $90-\mathrm{d}$ oral exposure. J Toxicol Environ Health Part A. 81:549-566.

Chiswell RK, Shaw GR, Eaglesham GK, Smith MJ, Norris RL, Seawright AA et al. (1999). Stability of cylindrospermopsin, the toxin from the cyanobacterium, Cylindrospermopsis raciborskii: effect of $\mathrm{pH}$, temperature, and sunlight on decomposition. Environ Toxicol. 14:155-161.

Chonudomkul D, Yongmanitchai W, Theeragool G, Kawachi M, Kasai F, Kaya K et al. (2004). Morphology, genetic diversity, temperature tolerance and toxicity of Cylindrospermopsis raciborskii (Nostocales, Cyanobacteria) strains from Thailand and Japan. FEMS Microbiol Ecol. 48:345-355.

Cirés S, Wörmer L, Ballot A, Agha R, Wiedner C, Velazquez D et al. (2014). Phylogeography of cylindrospermopsin and paralytic shellfish toxin-producing nostocales cyanobacteria from mediterranean europe (Spain). Appl Environ Microbiol. 80:1359-1370.

Cirés S, Wörmer L, Timón J, Wiedner C, Quesada A (2011). Cylindrospermopsin production and release by the potentially invasive cyanobacterium Aphanizomenon ovalisporum under temperature and light gradients. Harmful Algae. 10:668-675.

Cordeiro-Araújo MK, Chia MA, do Carmo Bittencourt-Oliveira M (2017). Potential human health risk assessment of cylindrospermopsin accumulation and depuration in lettuce and arugula. Harmful Algae. 68:217-223.

Davis TW, Orr PT, Boyer GL, Burford MA (2014). Investigating the production and release of cylindrospermopsin and deoxy-cylindrospermopsin by Cylindrospermopsis raciborskii over a natural growth cycle. Harmful Algae. 31:18-25.

de la Cruz AA, Hiskia A, Kaloudis T, Chernoff N, Hill D, Antoniou MG et al. (2013). A review on cylindrospermopsin: the global occurrence, detection, toxicity and degradation of a potent cyanotoxin. Environ Sci Process Impacts. 15:1979-2003.

Díez-Quijada L, Guzmán-Guillén R, Prieto Ortega A, Llana-Ruíz-Cabello M, Campos A, Vasconcelos V et al. (2018). New method for simultaneous determination of microcystins and cylindrospermopsin in vegetable matrices by SPE-UPLC-MS/ MS. Toxins. 10:406.

Dyble J, Tester PA, Litaker RW (2006). Effects of light intensity on cylindrospermopsin production in the cyanobacterial HAB species Cylindrospermopsis raciborskii. African J Mar Sci. 28:309-312.

Dziga D, Kokocinski M, Maksylewicz A, Czaja-Prokop U, Barylski J (2016). Cylindrospermopsin biodegradation abilities of Aeromonas sp. isolated from Rusałka Lake. Toxins. 8:55.

Esterhuizen-Londt M, Pflugmacher S (2016). Inability to detect free cylindrospermopsin in spiked aquatic organism extracts plausibly suggests protein binding. Toxicon. 122:89-93.

Everson S, Fabbro L, Kinnear S, Wright P (2011). Extreme differences in akinete, heterocyte and cylindrospermopsin concentrations with depth in a successive bloom involving Aphanizomenon ovalisporum (Forti) and Cylindrospermopsis raciborskii (Woloszynska) Seenaya and Subba Raju. Harmful Algae. 10:265-276.

Fadel A, Atoui A, Lemaire BJ, Vinçon-Leite B, Slim K (2014). Dynamics of the toxin cylindrospermopsin and the cyanobacterium Chrysosporum (Aphanizomenon) ovalisporum in a Mediterranean eutrophic reservoir. Toxins. 6:3041-3057. 
Fastner J, Heinze R, Humpage AR, Mischke U, Eaglesham GK, Chorus I (2003). Cylindrospermopsin occurrence in two German lakes and preliminary assessment of toxicity and toxin production of Cylindrospermopsis raciborskii (Cyanobacteria) isolates. Toxicon. 42:313-321.

Fathalli A, Jenhani AB, Moreira C, Azevedo J, Welker M, Romdhane M et al. (2011). Genetic variability of the invasive cyanobacteria Cylindrospermopsis raciborskii from Bir M'cherga reservoir (Tunisia). Arch Microbiol. 193:595-604.

Froscio SM, Humpage AR, Burcham PC, Falconer IR (2003). Cylindrospermopsininduced protein synthesis inhibition and its dissociation from acute toxicity in mouse hepatocytes. Environ Toxicol. 18:243-251.

Funari E, Testai E (2008). Human health risk assessment related to cyanotoxins exposure. Crit Rev Toxicol. 38:97-125.

Graham JL, Loftin KA, Meyer MT, Ziegler AC (2010). Cyanotoxin mixtures and taste-and-odor compounds in cyanobacterial blooms from the midwestern United States. Environ Sci Technol. 44:7361-7368.

Harada K-I, Ohtani I, Iwamoto K, Suzuki M, Watanabe MF, Watanabe M et al. (1994). Isolation of cylindrospermopsin from a cyanobacterium Umezakia natans and its screening method. Toxicon. 32:73-84.

Hawkins PR, Putt E, Falconer IR, Humpage AR (2001). Phenotypical variation in a toxic strain of the phytoplankter, Cylindrospermopsis raciborskii (Nostocales, Cyanophyceae) during batch culture. Environ Toxicol. 16:460-467.

Hawkins PR, Runnegar MTC, Jackson ARB, Falconer IR (1985). Severe hepatotoxicity caused by the tropical cyanobacterium (blue-green alga) Cylindrospermopsis raciborsckii (Woloszynska) Seenaya and Subba Raju isolated from a domestic water supply reservoir. Appl Environ Microbiol. 50:1292-1295.

Hoff-Risseti C, Dörr FA, Schaker PDC, Pinto E, Werner VR, Fiore MF (2013). Cylindrospermopsin and saxitoxin synthetase genes in Cylindrospermopsis raciborskii strains from Brazilian freshwater. PLoS One. 8:e74238.

Humpage AR, Falconer IR (2003). Oral toxicity of the cyanobacterial toxin cylindrospermopsin in male swiss albino mice: determination of No Observed Adverse Effect Level for deriving a drinking water guideline value. Environ Toxicol. 18:94-103.

Jiang Y, Xiao P, Yu G, Shao J, Liu D, Azevedo SM et al. (2014). Sporadic distribution and distinctive variations of cylindrospermopsin genes in cyanobacterial strains and environmental samples from Chinese freshwater bodies. Appl Environ Microbiol. 80:5219-5230.

Kinnear S (2010). Cylindrospermopsin: a decade of progress on bioaccumulation research. Mar Drugs. 8:542-564.

Kittler K, Schreiner M, Krumbein A, Manzei S, Koch M, Rohn S et al. (2012). Uptake of the cyanobacterial toxin cylindrospermopsin in Brassica vegetables. Food Chem. 133:875-879.

Klitzke S, Apelt S, Weiler C, Fastner J, Chorus I (2010). Retention and degradation of the cyanobacterial toxin cylindrospermopsin in sediments - the role of sediment preconditioning and DOM composition. Toxicon. 55:999-1007.

Klitzke S, Fastner J (2012). Cylindrospermopsin degradation in sediments-The role of temperature, redox conditions, and dissolved organic carbon. Water Res. 46:1549-1555. 
Kokociński M, Mankiewicz-Boczek J, Jurczak T, Spoof L, Meriluoto J, Rejmonczyk E et al. (2013). Aphanizomenon gracile (Nostocales), a cylindrospermopsinproducing cyanobacterium in Polish lakes. Environ Sci Pollut Res. 20: 5243-5264.

Li R, Carmichael WW, Brittain S, Eaglesham GK, Shaw GR, Liu YK et al. (2001a). First report of the cyanotoxin cylindrospermopsin and deoxycylindrospermopsin from Raphidiopsis curvata (cyanobacteria). J Phycol. 37:1121-1126.

Li R, Carmichael WW, Brittain S, Eaglesham GK, Shaw GR, Mahakahant A et al. (2001b). Isolation and identification of the cyanotoxin cylindrospermopsin and deoxy-cylindrospermopsin from a Thailand strain of Cylindrospermopsis raciborskii (Cyanobacteria). Toxicon. 39:973-980.

Machado J, Campos A, Vasconcelos V, Freitas M (2017). Effects of microcystin-LR and cylindrospermopsin on plant-soil systems: a review of their relevance for agricultural plant quality and public health. Environ Res. 153:191-204.

Martínez-Ruiz EB, Cooper M, Al-Zeer MA, Kurreck J, Adrian L, Szewzyk U (2020a). Manganese-oxidizing bacteria form multiple cylindrospermopsin transformation products with reduced human liver cell toxicity. Sci Tot Environ. 729:138924.

Martínez-Ruiz EB, Cooper M, Fastner J, Szewzyk U (2020b). Manganese-oxidizing bacteria isolated from natural and technical systems remove cylindrospermopsin. Chemosphere. 238:124625.

Mazmouz R, Chapuis-Hugon F, Mann S, Pichon V, Méjean A, Ploux O (2010). Biosynthesis of cylindrospermopsin and 7-epicylindrospermopsin in Oscillatoria sp strain PCC 6506: identification of the cyr gene cluster and toxin analysis. Appl Environ Microbiol. 76:4943-4949.

Mazmouz R, Chapuis-Hugon F, Pichon V, Méjean A, Ploux O (2011). The last step of the biosynthesis of the cyanotoxins cylindrospermopsin and 7-epicylindrospermopsin is catalysed by CyrI, a 2-oxoglutarate-dependent iron oxygenase. ChemBioChem. 12:858-862.

McGregor GB, Fabbro LD (2000). Dominance of Cylindrospermopsis raciborskii (Nostocales, Cyanoprokaryota) in Queensland tropical and subtropical reservoirs: implications for monitoring and management. Lakes Reserv Res Manage. 5:195-205.

McGregor GB, Sendall BC (2015). Phylogeny and toxicology of Lyngbya wollei (Cyanobacteria, Oscillatoriales) from north-eastern Australia, with a description of Microseira gen. nov. J Phycol. 51:109-119.

McGregor GB, Sendall BC, Hunt LT, Eaglesham GK (2011). Report of the cyanotoxins cylindrospermopsin and deoxy-cylindrospermopsin from Raphidiopsis mediterranea Skuja (Cyanobacteria/Nostocales). Harmful Algae. 10: 402-410.

Messineo V, Melchiorre S, Di Corcia A, Gallo P, Bruno M (2010). Seasonal succession of Cylindrospermopsis raciborskii and Aphanizomenon ovalisporum blooms with cylindrospermopsin occurrence in the volcanic Lake Albano, central Italy. Environ Toxicol. 25:18-27.

Metcalf JS, Young FM, Codd GA (2017). Performance assessment of a cylindrospermopsin ELISA with purified compounds and cyanobacterial extracts. Environ Forensics. 18:147-152. 
Mihali TK, Kellmann R, Muenchhoff J, Barrow KD, Neilan BA (2008). Characterization of the gene cluster responsible for cylindrospermopsin biosynthesis. Appl Environ Microbiol. 74:716-722.

Mohamed ZA, Alamri SA (2012). Biodegradation of cylindrospermopsin toxin by microcystin-degrading bacteria isolated from cyanobacterial blooms. Toxicon. 60:1390-1395.

Moreira C, Mendes R, Azevedo J, Vasconcelos V, Antunes A (2017). First occurrence of cylindrospermopsin in Portugal: a contribution to its continuous global dispersal. Toxicon. 130:87-90.

Nguyen TTL, Hoang TH, Nguyen TK, Duong TT (2017). The occurrence of toxic cyanobacterium Cylindrospermopsis raciborskii and its toxin cylindrospermopsin in the Huong River, Thua Thien Hue province, Vietnam. Environ Monit Assess. 189:490.

Niiyama Y, Tuji A, Tsujimura S (2011). Umezakia natans M. Watan. does not belong to Stigonemataceae but to Nostocaceae. Fottea. 11:163-169.

Norris RL, Eaglesham GK, Pierens G, Shaw GR, Smith MJ, Chiswell RK et al. (1999). Deoxycylindrospermopsin, an analog of cylindrospermopsin from Cylindrospermopsis raciborskii. Environ Toxicol. 14:163-165.

Nybom SM, Salminen SJ, Meriluoto JA (2008). Specific strains of probiotic bacteria are efficient in removal of several different cyanobacterial toxins from solution. Toxicon. 52:214-220.

Ohtani I, Moore RE, Runnegar MTC (1992). Cylindrospermopsin, a potent hepatotoxin from the blue-green alga Cylindrospermopsis raciborskii. $\mathrm{J}$ Am Chem Soc. 114:7941-7942.

Orr PT, Rasmussen JP, Burford MA, Eaglesham GK, Lennox SM (2010). Evaluation of quantitative real-time PCR to characterise spatial and temporal variations in cyanobacteria, Cylindrospermopsis raciborskii (Woloszynska) Seenaya et Subba Raju and cylindrospermopsin concentrations in three subtropical Australian reservoirs. Harmful Algae. 9:243-254.

Pearson LA, Dittmann E, Mazmouz R, Ongley SE, D’Agostino PM, Neilan BA (2016). The genetics, biosynthesis and regulation of toxic specialized metabolites of cyanobacteria. Harmful Algae. 54:98-111.

Pierangelini M, Sinha R, Willis A, Burford MA, Orr PT, Beardall J et al. (2015). Constitutive cylindrospermopsin pool size in Cylindrospermopsis raciborskii under different light and $\mathrm{CO}_{2}$ partial pressure conditions. Appl Environ Microbiol. 81:3069-3076.

Preussel K, Chorus I, Fastner J (2014). Nitrogen limitation promotes accumulation and suppresses release of cylindrospermopsins in cells of Aphanizomenon sp. Toxins. 6:2932-2947.

Preussel K, Stüken A, Wiedner C, Chorus I, Fastner J (2006). First report on cylindrospermopsin producing Aphanizomenon flos-aquae (Cyanobacteria) isolated from two German lakes. Toxicon. 47:156-162.

Preussel K, Wessel G, Fastner J, Chorus I (2009). Response of cylindrospermopsin production and release in Aphanizomenon flos-aquae (Cyanobacteria) to varying light and temperature conditions. Harmful Algae. 8:645-650.

Prieto AI, Guzmán-Guillén R, Díez-Quijada L, Campos A, Vasconcelos V, Jos Á et al. (2018). Validation of a method for cylindrospermopsin determination in vegetables: application to real samples such as lettuce (Lactuca sativa L.). Toxins. 10:63. 
Quesada A, Moreno E, Carrasco D, Paniagua T, Wörmer L, De Hoyos C et al. (2006). Toxicity of Aphanizomenon ovalisporum (Cyanobacteria) in a Spanish water reservoir. Europ J Phycol. 41:39-45.

Rücker J, Stüken A, Nixdorf B, Fastner J, Chorus I, Wiedner C (2007). Concentrations of particulate and dissolved cylindrospermopsin in 21 Aphanizomenon-dominated temperate lakes. Toxicon. 50:800-809.

Saker ML, Eaglesham GK (1999). The accumulation of cylindrospermopsin from the cyanobacterium Cylindrospermopsis raciborskii in tissues of the Redclaw crayfish Cherax quandricarinatus. Toxicon. 37:1065-1077.

Saker ML, Griffiths DJ (2000). The effect of temperature on growth and cylindrospermopsin content of seven isolates of Cylindrospermopsis raceborskii (Nostocales, Cyanophyceae) from water bodies in northern Australia. Phycologia. 39:349-354.

Saker ML, Metcalf JS, Codd GA, Vasconcelos VM (2004). Accumulation and depuration of the cyanobacterial toxin cylindrospermopsin in the freshwater mussel Anodonta cygnea. Toxicon. 43:185-194.

Saker ML, Nogueira IC, Vasconcelos VM, Neilan BA, Eaglesham GK, Pereira P (2003). First report and toxicological assessment of the cyanobacterium Cylindrospermopsis raciborskii from Portuguese freshwaters. Ecotoxicol Environ Safety. 55:243-250.

Schembri MA, Neilan BA, Saint CP (2001). Identification of genes implicated in toxin production in the cyanobacterium Cylindrospermopsis raciborskii. Environ Toxicol. 16:413-421.

Seifert M, McGregor G, Eaglesham G, Wickramasinghe W, Shaw G (2007). First evidence for the production of cylindrospermopsin and deoxy-cylindrospermopsin by the freshwater benthic cyanobacterium, Lyngbya wollei (Farlow ex Gornont) Speziale and Dyck. Harmful Algae. 6:73-80.

Shalev-Alon G, Sukenik A, Livnah O, Schwarz R, Kaplan A (2002). A novel gene encoding amidinotransferase in the cylindrospermopsin producing cyanobacterium Aphanizomenon ovalisporum. FEMS Microbiol Lett. 209:87-91.

Shaw GR, McKenzie RA, Wickramasinghe WA, Seawright AA, Eaglesham GK, Moore MR (2002). Comparative toxicity of the cyanobacterial toxin cylindrospermopsin between mice and cattle: human implications. Proceedings of the 10th International Conference on Harmful Algae, St. Pete Beach, FL. 465-467.

Shaw GR, Sukenik A, Livne A, Chiswell RK, Smith MJ, Seawright AA et al. (1999). Blooms of the cylindrospermopsin containing cyanobacterium, Aphanizomenon ovalisporum (Forti), in newly constructed lakes, Queensland, Australia. Environ Toxicol. 14:167-177.

Sinha R, Pearson LA, Davis TW, Muenchhoff J, Pratama R, Jex A et al. (2014). Comparative genomics of Cylindrospermopsis raciborskii strains with differential toxicities. BMC Genomics. 15:83.

Smith MJ, Shaw GR, Eaglesham GK, Ho L, Brookes JD. (2008). Elucidating the factors influencing the biodegradation of cylindrospermopsin in drinking water sources. Environ Toxicol. 23:413-421.

Spoof L, Berg KA, Rapala J, Lahti K, Lepistö L, Metcalf JS et al. (2006). First observation of cylindrospermopsin in Anabaena lapponica isolated from the boreal environment (Finland). Environ Toxicol. 21:552-560.

Stucken K, John U, Cembella A, Murillo AA, Soto-Liebe K, Fuentes-Valdés JJ et al. (2010). The smallest known genomes of multicellular and toxic cyanobacteria: 
comparison, minimal gene sets for linked traits and the evolutionary implications. PLoS One. 5:e9235.

Stucken K, John U, Cembella A, Soto-Liebe K, Vásquez M (2014). Impact of nitrogen sources on gene expression and toxin production in the diazotroph Cylindrospermopsis raciborskii CS-505 and non-diazotroph Raphidiopsis brookii D9. Toxins. 6:1896-1915.

Stüken A, Jakobsen KS (2010). The cylindrospermopsin gene cluster of Aphanizomenon sp strain 10E6: organization and recombination. Microbiology. 156: 2438-2451.

Sukenik A, Reisner M, Carmeli S, Werman M (2006). Oral toxicity of the cyanobacterial toxin cylindrospermopsin in mice: long-term exposure to low doses. Environ Toxicol. 21:575-582.

Terao K, Ohmori S, Igarashi K, Ohtani I, Watanabe MF, Harada K-I et al. (1994). Electron microscopic studies on experimental poisoning in mice induced by cylindrospermopsin isolated from the blue-green alga Umezakia natans. Toxicon. 32:833-843.

White JD, Hansen JD (2005). Total synthesis of (-)-7-epicylindrospermopsin, a toxic metabolite of the freshwater cyanobacterium Aphanizomenon ovalisporum, and assignment of its absolute configuration. J Org Chem. 70:1963-1977.

White SH, Duivenvoorden LJ, Fabbro LD, Eaglesham GK (2006). Influence of intracellular toxin concentrations on cylindrospermopsin bioaccumulation in a freshwater gastropod (Melanoides tuberculata). Toxicon. 47:497-509.

WHO (2003). Guidelines for safe recreational water environments. Vol. 1: Coastal and fresh waters. Geneva: World Health Organization. https://apps.who.int/ iris/handle/10665/42591

WHO (2020). Cyanobacterial toxins: Cylindrospermopsins. Background document for development of WHO Guidelines for Drinking-water Quality and Guidelines for Safe Recreational Water Environments. Geneva: World Health Organization. https://apps.who.int/iris/handle/10665/338063

Wiedner C, Rücker J, Fastner J, Chorus I, Nixdorf B (2008). Seasonal dynamics of cylindrospermopsin and cyanobacteria in two German lakes. Toxicon. 52:677-686.

Willis A, Adams MP, Chuang AW, Orr PT, O’Brien KR, Burford MA (2015). Constitutive toxin production under various nitrogen and phosphorus regimes of three ecotypes of Cylindrospermopsis raciborskii ((Wołoszyńska) Seenayya et Subba Raju). Harmful Algae. 47:27-34.

Willis A, Chuang AW, Woodhouse JN, Neilan BA, Burford MA (2016). Intraspecific variation in growth, morphology and toxin quotas for the cyanobacterium, Cylindrospermopsis raciborskii. Toxicon 119:307-310.

Wimmer KM,Strangman WK, Wright JL (2014).7-Deoxy-desulfo-cylindrospermopsin and 7-deoxy-desulfo-12-acetylcylindrospermopsin: two new cylindrospermopsin analogs isolated from a Thai strain of Cylindrospermopsis raciborskii. Harmful Algae. 37:203-206.

Wood S, Stirling D (2003). First identification of the cylindrospermopsin-producing cyanobacterium Cylindrospermopsis raciborskii in New Zealand. New Zeal J Mar Freshwater Res. 37:821-828.

Wörmer L, Cirés S, Carrasco D, Quesada A (2008). Cylindrospermopsin is not degraded by co-occurring natural bacterial communities during a 40-day study. Harmful Algae. 7:206-213. 
Wörmer L, Huerta-Fontela M, Cires S, Carrasco D, Quesada A (2010). Natural photodegradation of the cyanobacterial toxins microcystin and cylindrospermopsin. Environ Sci Technol. 44:3002-3007.

Yang Y, Chen Y, Cai F, Liu X, Wang Y, Li R (2018). Toxicity-associated changes in the invasive cyanobacterium Cylindrospermopsis raciborskii in response to nitrogen fluctuations. Environ Pollut. 237:1041-1049.

Yilmaz M, Phlips EJ, Szabo NJ, Badylak S (2008). A comparative study of Florida strains of Cylindrospermopsis and Aphanizomenon for cylindrospermopsin production. Toxicon. 52:594-595. 


\subsection{ANATOXIN-A AND ANALOGUES}

\section{Emanuela Testai}

Anatoxin-a (ATX) was isolated from strains of Dolichospermum (Anabaena) flosaquae originating from Canada (Carmichael et al., 1975). At the time, several types of toxins (anatoxins a-d) were suspected (Carmichael \& Gorham, 1978), of which, however, only one eventually led to the elucidation of the absolute structure (Devlin et al., 1977) for which the suffix "-a" was kept.

Besides ATX, the following also includes information on its variant homoanatoxin-a (HTX), where available. The genetics and biosynthesis of ATX and other neurotoxic substances with a high structural variability produced by some marine cyanobacteria (Aráoz et al., 2010) have been reviewed by Pearson et al. (2016) and Bruno et al. (2017).

\subsection{Chemical structures}

Anatoxins are secondary amine alkaloids (Devlin et al., 1977; Figure 2.3a). The first synthesis of ATX yielded a racemic mixture of stereoisomers with optically positive and negative activity (Campbell et al., 1979). Homoanatoxin-a is a structural variant (differing from ATX by an ethyl-group at the carbonyl-C; Figure 2.3b). It was first synthesised by Wonnacott et al. (1992) just before Skulberg et al. (1992) isolated it from a sample of Kamptonema (Oscillatoria) formosum. Due to its structural similarity to ATX, HTX is most probably produced by the same biosynthetic pathway, with the additional carbon deriving from L-methionine via $S$-adenosyl-methionine (Namikoshi et al., 2004).

Further natural analogues of ATX are dihydroATX (dhATX; Figure 2.3c) and dihydroHTX reduced on C7 and C8, respectively (Smith \& Lewis, 1987; Wonnacott et al., 1991).
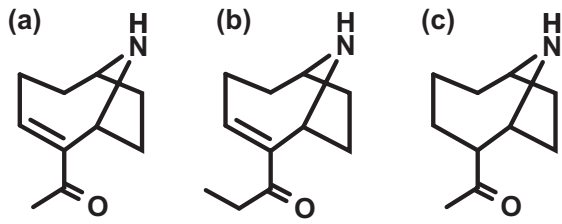

Figure 2.3 Chemical structure of anatoxin-a (a), homoanatoxin (b) and dihydroanatoxin-a (c). Anatoxin-a: molecular mass (monoisotopic): $165.115 \mathrm{Da}$; molecular weight (average): $165.237 \mathrm{~g} / \mathrm{mol}$. Homoanatoxin-a: molecular mass (monoisotopic) 179.131 Da; molecular weight (average): $179.264 \mathrm{~g} / \mathrm{mol}$. Dihydroanatoxin-a: molecular mass (monoisotopic) I67.131 Da; molecular weight (average): $167.252 \mathrm{~g} / \mathrm{mol}$. 


\subsubsection{Toxicity: mode of action}

The toxic effects of anatoxin-a, summarised in the following, are described in detail in the WHO Background Document on Anatoxin-a (WHO, 2020); see there for further information and references). In summary, ATX is rapidly and passively absorbed after ingestion and widely distributed to different tissues, including the brain. No information about its biotransformation is available but, overall, a low bioaccumulating potential can be anticipated. Anatoxin-a acts as a potent pre- and postsynaptic depolarising agent; it efficiently competes with acetylcholine for nicotinic receptors in neuromuscular junctions and the central nervous system, triggering neurotransmitter release with an increased stimulation of postsynaptic receptors. The cardiovascular system has also been indicated as a target organ. Death through the administration of a lethal ATX dose is due to muscular paralysis and respiratory failure (i.v. $\mathrm{LD}_{50}=85 \mu \mathrm{g} / \mathrm{kg}$ bw; i.p. $\mathrm{LD}_{50}=$ $260-315 \mu \mathrm{g} / \mathrm{kg} \mathrm{bw}$; oral $\mathrm{LD}_{50}>5000 \mu \mathrm{g} / \mathrm{kg} \mathrm{bw}$ ). Acute studies in animals led to deaths within minutes of gavage administration. After the administration of a sublethal single dose, mice readily recovered. Additional effects attributed to ATX in cell cultures include cytotoxic effects, caspase activation, apoptosis, induction of oxidative stress and formation of reactive oxygen species. Diagnosis of ATX and HTX poisoning in dogs and livestock has been reported due to neurotoxic effects after drinking and bathing in waters with ATX-producing cyanobacteria, such as species of the genera Phormidium, Oscillatoria and Tychonema.

On a weight of evidence basis, it can be concluded that ATX has no developmental or teratogenicity potential and is not mutagenic in bacteria. No in vivo carcinogenicity studies have been carried out. Regarding effects in humans, neurological symptoms (e.g., headache and confusion/ visual disturbance) were reported in 3 of 11 outbreaks associated with cyanobacteria in the USA in 2009-2010 (Hilborn et al., 2014), in which ATX was found in a concentration range of $0.05-15 \mu \mathrm{g} / \mathrm{L}$, while none of these symptoms were reported in the other 8 outbreaks, where ATX was not detected.

Homoanatoxin-a shows a mode of action and toxicological properties almost identical to its analogue ATX. Dihydro-anatoxin has been suggested as the congener most likely responsible for some dog deaths (Wood et al., 2017). Furthermore, a study indicates that dhATX is about fourfold more toxic than ATX when administered by gavage (Puddick et al., 2021).

\subsubsection{Derivation of health- based reference values}

The following section is taken directly from the WHO chemicals background document on anatoxins (WHO, 2020) which gives the considerations for the derivation of provisional guideline values for exposure to anatoxin in more detail. 
Acute exposure to ATX in animals led to deaths within minutes of gavage administration (Astrachan, Archer \& Hilbelink, 1980; Fawell et al., 1999). Since neither of the available repeated toxicity studies identified a nonlethal dose that caused lasting adverse effects, formal guideline values (GVs) (provisional or otherwise) cannot be derived based on the available information. In the 28-day study of Fawell et al. (1999), one of 20 animals in each of two dose groups died without signs that could be attributed to nontreatment effects. If it is conservatively assumed that these animals died from the effects of the toxin, the no observed adverse effect level (NOAEL) would be $98 \mu \mathrm{g} / \mathrm{kg}$ bw per day, but it could be as high as $2.46 \mathrm{mg} / \mathrm{kg}$ bw per day if these two animals were excluded (Fawell et al., 1999). Although GVs cannot be derived due to inadequate data, a "bounding value", or provisional health-based reference value, can be derived for short-term exposure using a highly conservative assumption to define the NOAEL at $98 \mu \mathrm{g} / \mathrm{kg}$. This value is lower than the estimated NOAEL for exposure via drinking-water calculated from data in Astrachan, Archer \& Hilbelink (1980) and the i.p. NOAEL for maternal toxicity identified by Rogers et al. (2005).

There is insufficient information to develop a long-term health-based reference value for ATX.

Default assumptions were applied as described in WHO (2009) for deriving the short-term drinking-water value and WHO (2003) for deriving the recreational water value.

\section{Calculation of provisional short-term drinking-water health-based reference value for ATX}

$$
\mathrm{HBRV}_{\text {short-term }}=\frac{\text { NOAEL }^{*} \mathrm{bw}^{*} \mathrm{P}}{\mathrm{UF}^{*} \mathrm{C}}=\frac{98 * 60 * 1.0}{100 * 2} \mu \mathrm{g} / \mathrm{L}=29.4 \mu \mathrm{g} / \mathrm{L} \approx 30 \mu \mathrm{g} / \mathrm{L}
$$

where

$\mathrm{HBRV}_{\text {short-term }}=$ short-term drinking-water health-based reference value

NOAEL $=$ no-observed-adverse-effect level $(98 \mu \mathrm{g} / \mathrm{kg}$ bw per day, based on Fawell et al., 1999)

$\mathrm{bw}=$ body weight (default $=60 \mathrm{~kg}$ for an adult $)$

$\mathrm{P}=$ fraction of exposure allocated to drinking-water (default for shortterm exposure $=100 \%$, considering that drinking-water is expected to be the most likely source of exposure)

$\mathrm{UF}=$ uncertainty factor $(10$ for interspecies variation $\times 10$ for intraspecies variation); an uncertainty factor for database deficiencies was not applied since the NOAEL is lower than the i.p. NOAEL for maternal toxicity

$\mathrm{C}=$ daily drinking-water consumption (default $=2 \mathrm{~L}$ for an adult). 


\section{Calculation of provisional recreational water health-based reference value for anatoxin-a}

$$
\mathrm{HBRV}_{\text {recreation }}=\frac{\mathrm{NOAEL}^{* \mathrm{bw}}}{\mathrm{UF} * \mathrm{C}}=\frac{98 * 15}{100 * 0.25} \mu \mathrm{g} / \mathrm{L}=58.8 \mu \mathrm{g} / \mathrm{L} \approx 60 \mu \mathrm{g} / \mathrm{L}
$$

where

$\mathrm{HBRV}_{\text {recreation }}=$ recreational water health-based reference value

NOAEL $=$ no-observed-adverse-effect level $(98 \mu \mathrm{g} / \mathrm{kg}$ bw per day, based on Fawell et al., 1999)

bw $=$ body weight $($ default $=15 \mathrm{~kg}$ for a child $)$

$\mathrm{UF}=$ uncertainty factor $(10$ for intraspecies variation $\times 10$ for interspecies variation)

$\mathrm{C}=$ daily incidental water consumption (default $=250 \mathrm{~mL}$ for a child).

\section{Considerations in applying the provisional health-based reference values}

Derivation of the provisional health-based reference values for ATX follows a highly conservative approach. As a result of inadequate data, the provisional health-based reference values derived above do not represent $\mathrm{WHO}$ GVs and therefore are not intended for use as scientific points of departure for developing regulations or standards. Nevertheless, a "bounding value" may be useful to guide actions and responses by water suppliers and health authorities. Based on the limited currently available studies of acute and subchronic ATX toxicity, exposure up to the values provided is expected to be safe for adults. Since infants and children can ingest a significantly larger volume of water per body weight (e.g., up to 5 times more drinking-water/ $\mathrm{kg}$ bw for bottle-fed infants than for an adult), it is recommended that alternative water sources, such as bottled water, are provided for bottlefed infants and small children when ATX concentrations are greater than $6 \mu \mathrm{g} / \mathrm{L}$ for short periods, as a precautionary measure.

The provisional drinking-water health-based reference value is based on a 28-day repeated dose study and so is applicable for short-term exposure. However, because ATX is acutely toxic, it is recommended that any exposure above this value be avoided.

The provisional health-based reference values are based on toxicological data for ATX. It is recommended that for assessing risk, total ATXs as gravimetric or molar equivalent are evaluated against the health-based reference values, based on a reasonable assumption that HTX has similar toxicity to ATX. There is evidence that dihydro-analogues of ATX and HTX are similarly toxic by the oral route of exposure; hence it would be prudent to include these in determinations of total ATXs, when present. 


\subsubsection{Production}

\subsubsection{Producing cyanobacteria}

Anatoxin was first found in Dolichospermum (Anabaena) flosaquae strains originating from Canada (Carmichael et al., 1975; Devlin et al., 1977) and later in Finland in Anabaena mendotae (Rapala et al., 1993), and D. circinale and Anabaena sp. in Finland and Japan (Sivonen et al., 1989; Park et al., 1993). Since then, many papers have been published reporting its production by several cyanobacteria species in many geographic areas by a variety of cyanobacteria taxa belonging to Nostocales - that is, Chrysosporum (Aphanizomenon) ovalisporum, Cuspidothrix, Raphidiopsis (Cylindrospermopsis), Cylindrospermum, Dolichospermum (Anabaena) circinale, D. flosaquae and D. lemmermannii - and to Oscillatoriales, that is, Blennothrix, Kamptonema, Microcoleus, Oscillatoria, Planktothrix, Phormidium and Tychonema (for species names and taxonomic changes, see Chapter 3). Tables 2.6 and 2.7 give examples of ATX contents in strains and concentrations in environmental samples, respectively. For further details, see reviews by Funari and Testai (2008), Pearson et al. (2016), Testai et al. (2016) and Cirés and Ballot (2016).

The production of ATX is species- and strain-specific. It is of interest that the American and European isolates of D. circinale investigated so far produce only ATX, while the Australian isolates exclusively produce saxitoxins, even if the two strains are reported to form a phylogenetically coherent group (Beltran \& Neilan, 2000).

Homoanatoxin-a was first isolated from a Kamptonema (Oscillatoria) formosum strain in Ireland (Skulberg et al., 1992). Subsequently, it was found to be produced by Raphidiopsis mediterranea in Japan and Oscillatoria in Norway, isolated from Microcoleus (Phormidium) autumnalis in New Zealand and from species of Dolichospermum/Anabaena in Ireland (see Testai et al., 2016).

\subsubsection{Toxin profiles}

Anatoxin has been found to be produced alone by Microcoleus (Phormidium) cf. autumnalis (James et al., 1997) as well as coproduced with HTX in Raphidiopsis mediterranea (Watanabe et al., 2003), Oscillatoria (Araóz et al., 2005), and with microcystins in Arthrospira fusiformis (Ballot et al., 2005), Microcystis sp. (Park et al., 1993) and Dolichospermum/Anabaena spp. (Fristachi \& Sinclair, 2008). M. autumnalis can contain high contents of HTX (together with ATX), showing large differences in toxin contents from week to week, and in some cases also in the same day (Wood et al., 2012). Non-axenic M. autumnalis strain CAWBG557 produces ATX, HTX and their dihydrogen derivatives dihydroanatoxin-a (dhATX) and dihydrohomoanatoxin-a (dhHTX; Heath et al., 2014). Dihydro-anatoxin-a 
Table 2.6 Neurotoxin contents reported from laboratory cultures of cyanobacteria

\begin{tabular}{|c|c|c|c|c|}
\hline Toxin & Taxon $^{a}$ & Content in $\mu g / g d w^{b}$ & Origin & Reference \\
\hline \multirow[t]{20}{*}{ ATX } & Oscillatoria sp. & 13000 & FIN & Sivonen et al. (1989) \\
\hline & Oscillatoria sp. & 2713 & FIN & Harada et al. (1993) \\
\hline & Oscillatoria sp. & 4000 & FIN & Araóz et al. (2005) \\
\hline & Aphanizomenon sp. & 6700 & FIN & Sivonen et al. (1989) \\
\hline & Aphanizomenon sp. & 1562 & FIN & Harada et al. (1993) \\
\hline & $\begin{array}{l}\text { Cuspidothrix } \\
\text { issatschenkoi }\end{array}$ & (400 fg/cell) & NZL & Wood et al. (2007a) \\
\hline & C. issatschenkoi & 2354 (I00 fg/cell) & DEU & Ballot et al. $(2010)$ \\
\hline & C. issatschenkoi & 1683 & NZL & Gagnon \& Pick (20I2) \\
\hline & Aph. flosaquae & $\approx 6500^{d}$ & FIN & Rapala et al. (1993) \\
\hline & $\begin{array}{l}\text { Dolichospermum } \\
\text { (Anabaena) } \\
\text { mendotae }\end{array}$ & $\approx 9800^{\mathrm{d}}$ & & Rapala et al. (1993) \\
\hline & D. flosaquae & $\approx 8800^{d}$ & & Rapala et al. (1993) \\
\hline & C. issatschenkoi & (9.4fg/cell) & NZL & Selwood et al. (2007) \\
\hline & D. flosaquae (4) & $1017-13000$ & FIN & Sivonen et al. (1989) \\
\hline & D. flosaquae & 13013 & CAN & Harada et al. (1993) \\
\hline & $D$ circinale & 8200 & FIN & Gallon et al. (1994) \\
\hline & D. circinale & 4400 & FIN & Harada et al. (1993) \\
\hline & D. circinale (2) & $1396-3500$ & FIN & Sivonen et al. (1989) \\
\hline & Arthrospira fusiformis & 0.3 & KEN & Ballot et al. (2005) \\
\hline & Arthrospira fusiformis & 10.4 & KEN & Kotut et al. (2006) \\
\hline & Nostoc carneum & 156 & IRN & $\begin{array}{l}\text { Ghassempour et al. } \\
(2005)\end{array}$ \\
\hline \multirow[t]{4}{*}{ HTX } & $\begin{array}{l}\text { Kamptonema } \\
\text { (Oscillatoria) } \\
\text { formosum }\end{array}$ & n.q. & NOR & Skulberg et al. (1992) \\
\hline & $\begin{array}{l}\text { Microcoleus } \\
\text { (Phormidium) } \\
\text { autumnalis }\end{array}$ & (437fg/cell;ATXeq) & NZL & Heath et al. (20I4) \\
\hline & $\begin{array}{l}\text { Raphidiopsis } \\
\text { mediterranea }\end{array}$ & n.q. & JPN & $\begin{array}{l}\text { Watanabe et al. } \\
(2003)\end{array}$ \\
\hline & Oscillatoria sp. (2) & n.q. & & Araóz et al. (2005) \\
\hline \multirow[t]{3}{*}{ ATX-S } & D. lemmermannii & 29-743 & DNK & $\begin{array}{l}\text { Henriksen et al. } \\
\text { (1997) }\end{array}$ \\
\hline & D. flosaquae & n.q. & CAN & $\begin{array}{l}\text { Carmichael \& } \\
\text { Gorham (I978) }\end{array}$ \\
\hline & $\begin{array}{l}\text { Sphaerospermopsis } \\
\text { torques-reginae }\end{array}$ & n.q. & BRA & Dörr et al. (2010) \\
\hline
\end{tabular}


Table 2.6 (Continued) Neurotoxin contents reported from laboratory cultures of cyanobacteria

\begin{tabular}{|c|c|c|c|c|}
\hline Toxin & $\operatorname{Taxon}^{a}$ & Content in $\mu g / g d w^{b}$ & Origin & Reference \\
\hline \multirow[t]{13}{*}{ STXs } & Aph. c.f. flosaquae ${ }^{d}$ & $\begin{array}{l}\text { GTX4: } \approx 7 \\
\text { dcGTX2: } \approx 5 \\
\text { neoSTX: } \approx 1 \\
\text { dcSTX: } \approx 0.8 \\
\text { dcGTX3: } \approx 0.5\end{array}$ & $\mathrm{CHN}$ & $\begin{array}{l}\text { Liu et al. (2006b) } \\
\text { Liu et al. }(2006 a)\end{array}$ \\
\hline & Aph. c.f. flosaquae ${ }^{c}$ & n.q. & USA & $\begin{array}{l}\text { Mahmood \& } \\
\text { Carmichael (1986) }\end{array}$ \\
\hline & Aph. gracile & n.q. (ca. 910 STXeq/L) & & Pereira et al. (2004) \\
\hline & Aph. gracile & $\begin{array}{l}\text { neoSTX: } 500-1600 \\
\text { STX: } 550-780 \\
\text { dcSTX: } 2.6-5.0 \\
\text { dcNEO: } 3.6-6.5\end{array}$ & TUR & Yilmaz et al. (2018) \\
\hline & Aphanizomenon sp. & $\begin{array}{l}\text { GTX5+neoSTX: } 34.6 \text { fg/ } \\
\text { cell }\end{array}$ & PRT & Dias et al. (2002) \\
\hline & $\begin{array}{l}\text { C. issatschenkoi } \\
\text { (LMECYA3I) }\end{array}$ & $\begin{array}{l}\text { GTX5: } 0.80 \\
\text { neoSTX: } 0.24 \\
\text { dcSTX: } 0.05 \\
\text { STX: } 0.05\end{array}$ & & $\begin{array}{l}\text { Pereira et al. (2000) } \\
\text { Li et al. (2003) }\end{array}$ \\
\hline & D. circinale & 1580 & AUS & Negri \& Jones (1995) \\
\hline & D. circinale (28) & $\begin{array}{l}0.77 \mathrm{fg} / \mathrm{cell} \\
(\mathrm{STX}+\mathrm{deSTX}+\mathrm{GTX} 2 / 3+\mathrm{d} \\
\text { eGTX2/3+GTX5+Cl/2) }\end{array}$ & AUS & Pereyra et al. (20I7) \\
\hline & D. circinale & $\begin{array}{l}\text { GTX3: } 1008 \\
\text { C2: I545 } \\
\text { STXeq: } 2553\end{array}$ & AUS & $\begin{array}{l}\text { Velzeboer et al. } \\
(2000)\end{array}$ \\
\hline & $\begin{array}{l}\text { D. perturbatum / } \\
\text { spiroides }\end{array}$ & GTX3: 14 & AUS & $\begin{array}{l}\text { Velzeboer et al. } \\
(2000)\end{array}$ \\
\hline & $\begin{array}{l}\text { Raphidiopsis } \\
\text { raciborskii (2) }\end{array}$ & STXeq: 0.010 & BRA & Lagos et al. (1999) \\
\hline & R. raciborskii & STX: 0.3 & BRA & Castro et al. (2004) \\
\hline & Planktothrix sp. & n.q. STX & ITA & Pomati et al. (2000) \\
\hline
\end{tabular}

Numbers following taxa indicate the number of tested strains if more than a single strain was analysed. The taxonomic classification is listed according to the current nomenclature with earlier synonyms given in parentheses (for an overview on recent changes in taxonomy, see Chapter 3 ).

n.q.: not quantified, only qualitative detection reported.

a The taxon given here may deviate from that given in the publication. For changes in taxonomy, see Chapter 3.

b If not specified otherwise.

c Several strains of Aph. flosaquae have been reclassified as Aphanizomenon sp. or Aph. gracile, respectively.

$\mathrm{d} \approx$ Estimated from figure in publication. 
Table 2.7 Neurotoxin contents of biomass and concentrations in water reported from environmental samples

\begin{tabular}{|c|c|c|c|c|c|}
\hline Toxin & Dominant taxa $^{a}$ & $\begin{array}{l}\text { Concentrations/ } \\
\text { contents/cell quota }\end{array}$ & Type & Origin & Reference \\
\hline \multirow[t]{10}{*}{ ATX } & $\begin{array}{l}\text { Phormidium } \\
\text { favosum }\end{array}$ & $8000 \mu g / g d w$ & $R$ & FRA & Gugger et al. (2005) \\
\hline & $\begin{array}{l}\text { Microcoleus. cf. } \\
\text { autumnalis }\end{array}$ & $\begin{array}{l}444 \mu g / L \\
16 \mu g / g ~ d w\end{array}$ & L & IRL & James et al. (1997) \\
\hline & $\begin{array}{l}\text { Dolichospermum } \\
\text { sp. }\end{array}$ & $\begin{array}{l}390 \mu \mathrm{g} / \mathrm{L} \\
100 \mu \mathrm{g} / \mathrm{g} d \mathrm{dw}\end{array}$ & L & IRL & James et al. (1997) \\
\hline & $\begin{array}{l}\text { Dolichospermum } \\
\text { sp. } \\
\text { Aphanizomenon } \\
\text { sp. }\end{array}$ & $13 \mu \mathrm{g} / \mathrm{L}$ intra+extra & L/Res. & DEU & $\begin{array}{l}\text { Bumke-Vogt et al. } \\
\text { (1999) }\end{array}$ \\
\hline & $\begin{array}{l}\text { Aphanizomenon } \\
\text { sp. }\end{array}$ & $35 \mu g / g d w$ & L & RUS & Chernova et al. (20I7) \\
\hline & $\begin{array}{l}\text { Cuspidothrix } \\
\text { issatschenkoi }\end{array}$ & $1430 \mu \mathrm{g} / \mathrm{L}$ & L & NZL & Wood et al. (2007a) \\
\hline & $\begin{array}{l}\text { Dolichospermum } \\
\text { sp. } \\
\text { Aphanizomenon } \\
\text { sp. } \\
\text { Cylindrospermum } \\
\text { sp. }\end{array}$ & $4400 \mu g / g d w$ & L & FIN & Sivonen et al. (1989) \\
\hline & $\begin{array}{l}\text { Arthrospira } \\
\text { fusiformis }\end{array}$ & $2 \mu g / g d w$ & L & KEN & Ballot et al. (2005) \\
\hline & $\begin{array}{l}\text { Anabaena sp. } \\
\text { Art. fusiformis }\end{array}$ & $223 \mu \mathrm{g} / \mathrm{g} \mathrm{dw}$ & L & KEN & Kotut et al. (2006) \\
\hline & $\begin{array}{l}\text { Microcoleus cf. } \\
\text { autumnalis }\end{array}$ & $0.027 \mu g / g$ ww & $\mathrm{R}$ & NZL & Wood et al. (2007a) \\
\hline \multirow[t]{2}{*}{ HTX } & M. cf. autumnalis & $0.44 \mu g / g$ ww & $\mathrm{R}$ & NZL & Wood et al. (2007b) \\
\hline & Anabaena spp. & $34 \mu g / L$ & L & IRL & Furey et al. (2003) \\
\hline dhATX & M. cf. autumnalis & $2118 \mu g / L$ & $P$ & & Wood et al. (2017) \\
\hline ATX(S) & D. lemmermannii & $3300 \mu g / g d w$ & L & DNK & Henriksen et al. (1997) \\
\hline \multirow[t]{5}{*}{ STXs } & D. lemmermannii & $\begin{array}{l}224 \mu g / g d w \\
\text { STXeq }\end{array}$ & L & DNK & $\begin{array}{l}\text { Kaas \& Henriksen } \\
(2000)\end{array}$ \\
\hline & D. lemmermannii & $\begin{array}{l}930 \mu g / g ~ d w \\
\text { STXeq } \\
1000 \mu g / L \text { STXeq }\end{array}$ & L & FIN & Rapala et al. (2005) \\
\hline & D. lemmermannii & $600 \mu g / L ~ S T X$ & $\mathrm{R}$ & RUS & Grachev et al. (20।8) \\
\hline & D. circinale & $\begin{array}{l}4466 \mu g / g d w \\
\text { STXeq }\end{array}$ & L/R & AUS & Velzeboer et al. (2000) \\
\hline & D. circinale & $\begin{array}{l}2040 \mu \mathrm{g} \mathrm{STXeq} / g \\
\mathrm{dw}\end{array}$ & $L / R$ & AUS & Humpage et al. (1994) \\
\hline
\end{tabular}


Table 2.7 (Continued) Neurotoxin contents of biomass and concentrations in water reported from environmental samples

\begin{tabular}{|c|c|c|c|c|c|}
\hline Toxin & Dominant taxa ${ }^{a}$ & $\begin{array}{c}\text { Concentrations/ } \\
\text { contents/cell quota }\end{array}$ & Type & Origin & Reference \\
\hline & Planktothrix sp. & $\begin{array}{l}\text { I8I } \mu \mathrm{g} / \mathrm{L} \mathrm{STX} \\
\text { (intra) }\end{array}$ & $L$ & ITA & Pomati et al. (2000) \\
\hline & Aph. flosaquae & $4.7 \mu g / g d w$ STXeq & Res & PRT & Ferreira et al. (200I) \\
\hline & Aph. favaloroi & $\begin{array}{l}\text { STX: } 42 \mu g / g ~ d w \\
0.17 \mathrm{fg} / \mathrm{cell} \\
\text { neoSTX: } \\
\quad 17 \mu g / g \mathrm{dw} \\
0.07 \mathrm{fg} / \mathrm{cell}\end{array}$ & $\mathrm{L}$ & GRE & $\begin{array}{l}\text { Moustaka-Gouni et al. } \\
(2017)\end{array}$ \\
\hline & $\begin{array}{l}\text { Aphanizomenon } \\
\text { sp. }\end{array}$ & $\begin{array}{l}\text { neoSTX: } 2.3 \mu g / g \\
\text { dw } \\
\text { dcSTX: } 2.3 \mu g / g d w \\
\text { dcGTX3: } \\
0.5 \mu g / g d w\end{array}$ & L & $\mathrm{CHI}$ & Liu et al. (2006b) \\
\hline & R. raciborskii & $\begin{array}{c}3.14 \mu \mathrm{g} / \mathrm{L} \mathrm{STXeq} \\
\text { (intra+extra) }\end{array}$ & Res & BRA & Costa et al. (2006) \\
\hline & $\begin{array}{l}\text { Microseira } \\
\text { (Lyngbya) wollei }\end{array}$ & $\begin{array}{l}\text { 19-73 } \mu g \\
\text { STXeq/g dw }\end{array}$ & $\mathrm{R}$ & USA & Foss et al. (2012) \\
\hline & M. wollei & $58 \mu g$ STXeq/g dw & L/Res & USA & Carmichael et al. (1997) \\
\hline
\end{tabular}

Contents are given in $\mu$ g toxin per gram dry weight $(\mathrm{dw})$ or wet weight $(\mathrm{ww})$. For individual studies, maximum values are given. Samples were collected in different types of waterbodies (L: lakes, $\mathrm{R}$ : rivers, P: pond, Res: reservoirs) in countries as indicated. For saxitoxins, contents are reported as saxitoxin equivalents (STXeq) in some reports or as individual variants (see text). The taxonomic classification is listed according to the current nomenclature with earlier synonyms given in parentheses (for an overview on recent changes in taxonomy, see Chapter 3).

a The taxon given here may deviate from that given in the publication. For changes in taxonomy, see Chapter 3.

has been reported to be produced in amounts much higher than those of ATX by strains of M. autumnalis (Wood et al., 2017; Puddick et al., 2021)

The few data available on ATX cell quota range from $90 \mathrm{fg} / \mathrm{cell}$ in Cuspidothrix issatschenkoi (Selwood et al., 2007) to $500 \mathrm{fg} / \mathrm{cell}$ in $M$. autumnalis (Heath et al., 2014). Cell quota detected in Tychonema bourrelly $i$ were in a similarly wide range, 10-350 fg/cell (Shams et al., 2015).

The highest contents within the wide variability of ATX contents reported from strains grown as laboratory cultures, in the order of a few $\mathrm{mg} / \mathrm{g} \mathrm{dw}$, were found in strains of the genera Oscillatoria, Phormidium, Aphanizomenon, Cuspidothrix and Dolichospermum. The maximum value $(13 \mathrm{mg} / \mathrm{g} \mathrm{dw}$ ) was found in D. flosaquae and Oscillatoria sp., while much lower contents - generally by 1-2 orders of magnitude - of ATX are reported for cyanobacteria of other genera (Testai et al., 2016). 


\subsubsection{Biosynthesis and regulation}

Cyanobacteria produce (+)ATX, but no specific studies have addressed the stereoselectivity of the biochemical reaction towards the positive enantiomer.

Anatoxin biosynthesis and regulation have been reviewed in Pearson et al. (2016). Méjean et al. (2009) reported the identification of the first gene cluster coding for the biosynthesis of ATXs (ana) within the sequenced genome of Oscillatoria sp. PCC 6506, producing mainly HTX. In the following years, five other ana clusters were identified within Dolichospermum/ Anabaena sp. 37, Oscillatoria sp. PCC 6407, Cylindrospermum stagnale sp. PCC 7417, Cuspidothrix issatschenkoi RM-6, C. issatschenkoi LBRI48 and C. issatschenkoi CHABD3 (Rantala-Ylinen et al., 2011; Shih et al., 2013; Méjean et al., 2014; Jiang et al., 2015).

Each cluster showed general similarities in the protein functions, with a high percentage of identity in nucleotide sequence (with the core genes anaB-G being conserved within all strains), but differences in the organisation of genes (Pearson et al., 2016), leading to different toxin profiles between the producing organisms.

The biosynthesis of the ATXs involves a polyketide synthase (PKS) family of multifunctional enzymes with a modular structural organisation as described in Méjean et al. (2014). A detailed biochemical description of the adenylation domain protein $\mathrm{AnaC}$ revealed the activation of proline as starter, and not glutamate as previously proposed (Dittmann et al., 2013). The biosynthetic pathway describes $\mathrm{AnaB}, \mathrm{AnaC}$ and $\mathrm{AnaD}$ as acting in the first steps (which have been fully reproduced in vitro; Méjean et al., 2009; Méjean et al., 2010; Mann et al., 2011), and AnaE, AnaF, Ana J and AnaG catalysing the following steps, with the latter adding two carbons and methylating the substrate to produce HTX. The release of ATXs may be catalysed by the thioesterase AnaA, although this has not been experimentally verified (Pearson et al., 2016) or a spontaneous decarboxylation step may occur to yield the amine alkaloid ATX (Dittmann et al., 2013).

The molecular regulation of ATX has not been sufficiently studied so far. Under conditions where ana $A$, anaJ, anaF and ana $G$ transcripts were present in C. issatschenkoi CHABD3, no ATX was detected (Jiang et al., 2015). This result may indicate that the regulation of ATX occurs at the post-transcriptional level, but interpretation is limited by the lack of investigation of ATX dihydroderivatives production (Pearson et al., 2016).

An influence of light, temperature, phosphorous and nitrogen on cellular ATX content is reported, and it seems that the influence of environmental factors is strain-specific (Harland et al., 2013; Neilan et al., 2013; Boopathi \& Ki, 2014; Heath et al., 2014). Overall, the influence of factors, such as light and temperature, reported for the ATX content in Dolichospermum/Anabaena and Aphanizomenon cultures varies around 2-4-fold, not exceeding a factor of 7 (Rapala \& Sivonen, 1998), and a 
similar range is reported for HTX in relation to phosphorus (Heath et al., 2014). HTX production also seems to be linked to the culture growth phase in Raph. mediterranea strain LBRI 48 (Namikoshi et al., 2004). However, the results of most studies were not strongly supported by statistical analyses; furthermore, determining the effect of nutrient limitation requires continuous culture systems or evaluating batch culture data in relation to growth rates, yet in few studies this was done.

\subsubsection{Occurrence in water environments}

Anatoxin-a has a worldwide distribution that includes temperate, tropical and cold climatic regions (Fristachi \& Sinclair, 2008). Although the occurrence of ATX has been less frequently surveyed than that of microcystins, based on the available data, it is evident that a wide variability in ATX contents is reported from environmental freshwater samples (Testai et al., 2016).

In the USA, surveys conducted in Florida in 1999 and 2000 did not detect ATX in most of the samples tested, but the maximum concentration found amounted to $156 \mu \mathrm{g} / \mathrm{L}$ (Fristachi \& Sinclair, 2008); in Nebraska, variable ATX concentrations up to $35 \mu \mathrm{g} / \mathrm{L}$ were measured in water samples collected from eight reservoirs between 2009 and 2010 (Al-Sammak et al., 2014), and the highest ATX levels $(1170 \mu \mathrm{g} / \mathrm{L})$ were found in Washington State, where three waterbodies had long-term recurring blooms (Trainer \& Hardy, 2015).

In Europe, a monitoring programme on 80 German lakes and reservoirs found ATX in $25 \%$ of the surveyed waterbodies and in $22 \%$ of water samples with a maximum total concentration of $13.1 \mu \mathrm{g} / \mathrm{L}$ (Bumke-Vogt et al., 1999). In Finland, in a survey of 72 lakes with variable trophic state, nearly half of the blooms dominated by Dolichospermum did not contain detectable ATX (Rapala \& Sivonen, 1998). Furthermore, in Finland, hepatotoxic blooms have been found to be twice as common as neurotoxic ones (Rapala \& Sivonen, 1998). Among 20 Irish lakes investigated, homoanatoxin-a was found in four inland waters dominated by blooms of Dolichospermum spp. at concentrations of up to $34 \mu \mathrm{g} / \mathrm{L}$ (Furey et al., 2003).

In Kenya, seven lakes (two freshwater and five alkaline saline waters) and the hot spring mats of Lake Bogoria were investigated for cyanotoxins, and ATX was recorded in almost all of them, at up to $1260 \mu \mathrm{g} / \mathrm{g} \mathrm{dw}$ but not as dissolved toxin (Kotut et al., 2006). ATX concentrations up to 2.0 $\mu \mathrm{g} / \mathrm{g} \mathrm{dw}$ were detected in two alkaline Kenyan crater lakes, dominated by Arthrospira fusiformis (Ballot et al., 2005).

A number of publications have addressed the production of ATX by benthic cyanobacteria: the highest toxin concentrations being reported in a river mat sample ( $8 \mathrm{mg} / \mathrm{g} \mathrm{dw})$ in France, formed by benthic Kamptonema (Phormidium) formosum (Gugger et al., 2005). Levels ranging from 1.8 to $15.3 \mu \mathrm{g}$ ATX/g of lyophilised weight were detected in Phormidium biofilms in the Tarn River (France) with high spatiotemporal variability and the highest concentrations 
being recorded at the end of the summer period (Echenique-Subiabre et al., 2018). The maximum ATX concentration in surface waters reported to date was found in a lake in Ireland $(444 \mu \mathrm{g} / \mathrm{L})$, where no surface blooms were previously observed, and as in the French case, the causative agent was a benthic cyanobacterium (James et al., 1997). Benthic, mat-forming cyanobacteria are common also in New Zealand rivers, frequently populated by Phormidium, known to produce ATX and HTX, the latter at contents up to $4400 \mu \mathrm{g} / \mathrm{g} \mathrm{dw}$ (Wood et al., 2007b; Wood et al., 2012). In a study motivated by dog deaths, Wood et al. (2017) reported moderate concentrations of $\operatorname{ATX}(25 \mu \mathrm{g} / \mathrm{L})$ and high levels of dhATX $(2,118 \mu \mathrm{g} / \mathrm{L})$, indicating that the latter may be present in higher concentrations than estimated so far. These concentrations, however, are associated with benthic grab samples and do not represent concentrations in larger water volumes (see also section 12.8 on benthic sampling). For an example of animal poisoning at a recreational lake and possible implications for human health see also Box 5.6.

Benthic cyanobacterial mats dominated by Phormidium terebriformis, Microseira (Lyngbya) wollei, Spirulina subsalsa and Synechococcus bigranulatus in the hot springs at the shore of Lake Bogoria (Kenya) contained MC and ATX (Krienitz et al., 2003). Recently, periphytic and tychoplanktic Tychonema have been identified as a producer of ATX and HTX in Italian alpine lakes (Salmaso et al., 2016) and in a German lowland lake (Fastner et al., 2018). However, identification at species level has not always been undertaken for benthic cyanobacteria (Puschner et al., 2008; Faassen et al., 2012), and it seems likely that more HTX-producing Oscillatoria or Phormidium/Microcoleus populations - and species - will be identified as research continues.

Anatoxin-a occurrence is not limited to freshwater; indeed, it has been found in brackish waters in samples collected off the coast of Poland in the Baltic Sea at the beginning of September (Mazur \& Plinski, 2003) and in Chesapeake Bay (USA) at concentrations ranging from $3 \times 10^{-3}$ to $3 \mathrm{mg} / \mathrm{L}$ (Tango \& Butler, 2008). Although different planktonic and benthic genera occur and possibly dominate in brackish water (Nodularia, Aphanizomenon, Microcystis, Dolichospermum, Anabaena and Phormidium/Microcoleus), in these environments ATX seems to be produced exclusively by species formerly assigned to Phormidium (Lopes et al., 2014). Moreover, ATX production was found in a benthic marine cyanobacterium (Hydrocoleum lyngbyaceum) in New Caledonia (Méjean et al., 2010).

Biocrust-forming cyanobacteria inhabiting the Kaffiøyra Plain (in the Arctic region) are able to synthesise ATX from 0.322 to $0.633 \mathrm{mg} / \mathrm{g} \mathrm{dw}$ (Chrapusta et al., 2015).

The available data and information have not linked ATX to human poisoning via drinking-water (Humpage, 2008). Surveys of cyanotoxins in drinking-water supplies in 1999/2000 across Florida found ATX only in three finished waters with concentrations up to $8.5 \mu \mathrm{g} / \mathrm{L}$ (Burns, 2008). Nevertheless, ATX should not be excluded as a potential human health 
hazard because some Oscillatoria sp. potentially producing ATX can proliferate in facilities and tanks for water storage (Osswald et al., 2007).

\subsubsection{Bioaccumulation}

The issue has been extensively reviewed in Testai et al. (2016). Anatoxin-a has been detected at low concentrations $(0.51-43.3 \mu \mathrm{g} / \mathrm{g})$ in Blue Tilapia fish in Florida (Burns, 2008). However, in Nebraska, this toxin could not be detected in fish from a reservoir although it was present in samples of the water and aquatic plants at the location (Al-Sammak et al., 2014). Concentrations similar to those in Tilapia were found in carp and juvenile trout exposed to high concentrations of ATX in an experimental setting (Osswald et al., 2007; Osswald et al., 2011); when mussels were experimentally exposed to live cells of an Anabaena strain (ANA 37), much lower levels were detected in the tissues (Osswald et al., 2008).

A special case of food items potentially containing ATX are "blue-green algal food supplements" (BGAS) that are usually produced from Spirulina maxima or Arthrospira (Spirulina) platensis and Aph. flosaquae. In Spirulinal Arthrospira-based BGAS, no direct evidence of the presence of ATX has been reported, but two nontoxic metabolites of this toxin have been found at contents of up to $19 \mu \mathrm{g} / \mathrm{g} \mathrm{dw}$ (Draisci et al., 2001). When 39 samples containing the genera Arthrospira, Spirulina and Aphanizomenon were analysed, three $(7.7 \%)$ contained ATX at concentrations ranging from 2.5 to $33 \mu \mathrm{g} / \mathrm{g} \mathrm{dw}$ (Rellán et al., 2009). See also section 5.4.

\subsubsection{Environmental fate}

\subsubsection{Partitioning between cells and water}

Anatoxins can be released from producing cells into the surrounding water, but very different results were reported in the ratio between the intra- and extracellular fractions, likely depending on the species and environmental conditions (Testai et al., 2016) as well as on the sensitivity of the analytical method used especially in earlier studies (Wood et al., 2011; Testai et al., 2016). There is currently no evidence that ATXs are released from viable, intact cells to a substantial degree. It may be hence concluded that ATXs are largely confined to viable cyanobacterial cells in the environment and that extracellular release occurs mainly through cell senescence and lysis.

Once released from cells into the surrounding water, ATX can undergo chemical and biological degradation (Rapala \& Sivonen, 1998) (see below). This is a challenge for its detection in environmental samples: the presence of ATX degradation products reported in some Finnish lakes at concentrations of $100-710 \mu \mathrm{g} / \mathrm{L}$ for epo-ATX and at $5-150 \mu \mathrm{g} / \mathrm{L}$ for dihydro-ATX (Rapala et al., 2005) indicates that ATX derivatives may serve as indicator of the previous presence of dissolved ATX. 


\subsubsection{Chemical breakdown}

In laboratory studies, ATX has been reported to undergo a rapid photochemical degradation in sunlight, under conditions of the light intensity and $\mathrm{pH}$ ranges expected to be associated with blooms: Stevens and Krieger (1991) observed the reaction rate to be positively related to both $\mathrm{pH}$ and light intensity, with half-lives for photochemical breakdown at $\mathrm{pH} \geq 6$ of $1.6-11.5 \mathrm{~h}$, whereas at $\mathrm{pH}$ of 2 , ATX was very stable. Kaminski et al. (2013) showed that ATX was resistant to photosynthetic active radiation with degradation dependent on $\mathrm{pH}$ : at low $\mathrm{pH}(<3)$, ATX proved stable when stored at room temperature, with minimal $(\leq 3 \%)$ losses over a period of 9 weeks, but gradual degradation ( $\geq 37 \%$ losses) occurred at neutral ( $\mathrm{pH} 7$ ) and high $\mathrm{pH}$ (9.5). Anatoxin-a is relatively stable in the dark (Matsunaga et al., 1989), with a half-life of 4-10 days (Stevens \& Krieger, 1991), at a $\mathrm{pH}$ of 9.

The mouse bioassay results show that regardless of process, photolytic or nonphotolytic, the breakdown products are of reduced toxicity and not antagonistic towards the effects of ATX (Stevens \& Krieger, 1991).

In conclusion, once released from cyanobacterial cells and dissolved in water, ATX may degrade faster in water with high $\mathrm{pH}$ and further mitigating factors (e.g., microbial activity, elevated temperature), but may generally be more stable than previously assumed.

\subsubsection{Biodegradation}

Biodegradation by bacteria also has an important role: under natural conditions, ATX and HTX are partially or totally degraded and converted to dihydro- and epoxy-derivatives (James et al., 2005). Isolated Pseudomonas spp. degraded ATX at a rate of $2-10 \mu \mathrm{g} / \mathrm{mL} \times$ day (Kiviranta et al., 1991), organisms in sediments reduced ATX concentrations by $25-48 \%$ in 22 days (Rapala et al., 1994), and a laboratory experiment with lake sediments and natural bacteria resulted in a half-life of 5 days (Kormas \& Lymperopoulou, 2013).

Dihydroanatoxin-a has been considered the major ATX degradation product, representing from $17 \%$ to $90 \%$ of the total ATX concentration in the environment (Mann et al., 2011). Its concentrations gradually increased over time, paralleled by a decrease in ATX concentrations (Wood et al., 2011), although the involved enzymatic steps are not fully clarified. However, Heath et al. (2014) found that dhATX can account for $64 \%$ of the total intracellular ATX quota, suggesting that it is internally formed and is not only the product of cell lysis and environmental degradation, but is synthesised de novo in the cells.

In conclusion, due to the (photo)chemical and biological degradation of ATX and HTX, environmental samples invariably contain large amounts of these derivatives. Similar reactions can be expected to occur within biota, 
including mammals, although these have so far not been reported. Therefore, both environmental and forensic (e.g., in case of animal poisoning) analyses should also include an investigation of these degradation products.

\section{REFERENCES}

Al-Sammak MA, Hoagland KD, Cassada D, Snow DD (2014). Co-occurrence of the cyanotoxins BMAA, DABA and anatoxin-a in Nebraska reservoirs, fish, and aquatic plants. Toxins. 6:488-508.

Aráoz R, Molgó J, De Marsac NT (2010). Neurotoxic cyanobacterial toxins. Toxicon. 56:813-828.

Araóz R, Nghiem HO, Rippka R, Palibroda N, de Marsac NT, Herdman M (2005). Neurotoxins in axenic oscillatorian cyanobacteria: coexistence of anatoxinalpha and homoanatoxin-alpha determined by ligand-binding assay and GC/ MS. Microbiology. 151:1263-1273.

Astrachan N, Archer B, Hilbelink D (1980). Evaluation of the subacute toxicity and teratogenicity of anatoxin-a. Toxicon. 18:684-688.

Ballot A, Fastner J, Lentz M, Wiedner C (2010). First report of anatoxin-a-producing cyanobacterium Aphanizomenon issatschenkoi in northeastern Germany. Toxicon. 56:964-971.

Ballot A, Krienitz L, Kotut K, Wiegand C, Pflugmacher S (2005). Cyanobacteria and cyanobacterial toxins in the alkaline crater lakes Sonachi and Simbi, Kenya. Harmful Algae. 4:139-150.

Beltran EC, Neilan BA (2000). Geographical segregation of the neurotoxinproducing cyanobacterium Anabaena circinalis. Appl Environ Microbiol. 66: $4468-4474$.

Boopathi T, Ki J-S (2014). Impact of environmental factors on the regulation of cyanotoxin production. Toxins. 6:1951-1978.

Bruno M, Ploux O, Metcalf JS, Méjean A, Pawlik-Skowronska B, Furey A (2017). Anatoxin-a, homoanatoxin-a, and natural analogues. In: Meriluoto J, Spoof L, Codd GA et al., editors: Handbook of cyanobacterial monitoring and cyanotoxin analysis. Chichester: John Wiley \& Sons:138-147.

Bumke-Vogt C, Mailahn W, Chorus I (1999). Anatoxin-a and neurotoxic cyanobacteria in German lakes and reservoirs. Environ Toxicol. 14:117-125.

Burns J (2008). Toxic cyanobacteria in Florida waters. In: Hudnell HK, editors: Cyanobacterial harmful algal blooms: state of the science and research needs. New York: Springer:127-137.

Campbell HF, Edwards OE, Elder JW, Kolt R (1979). Total synthesis of DL-anatoxina and DL-isoanatoxin-a. Polish J Chem. 53:27-37.

Carmichael WW, Biggs DF, Gorham PR (1975). Toxicology and pharmacological action of Anabaena flos-aquae toxin. Science. 187:542-544.

Carmichael WW, Evans WR, Yin QQ, Bell P, Moczydlowski E (1997). Evidence for paralytic shellfish poisons in the freshwater cyanobacterium Lyngbya wollei (Farlow ex Gomont) comb. nov. Appl Environ Microbiol. 63:3104-3110.

Carmichael WW, Gorham PR (1978). Anatoxins from clones of Anabaena flos-aquae isolated from lakes of western Canada. Mitt Int Verein Limnol. 21:285-295. 
Castro D, Vera D, Lagos N, García C, Vásquez M (2004). The effect of temperature on growth and production of paralytic shellfish poisoning toxins by the cyanobacterium Cylindrospermopsis raciborskii C10. Toxicon. 44:483-489.

Chernova E, Sidelev S, Russkikh I, Voyakina E, Babanazarova O, Romanov R et al. (2017). Dolichospermum and Aphanizomenon as neurotoxins producers in some Russian freshwaters. Toxicon. 130:47-55.

Chrapusta E, Węgrzyn M, Zabaglo K, Kaminski A, Adamski M, Wietrzyk P et al. (2015). Microcystins and anatoxin-a in Arctic biocrust cyanobacterial communities. Toxicon. 101:35-40.

Cirés S, Ballot A (2016). A review of the phylogeny, ecology and toxin production of bloom-forming Aphanizomenon spp. and related species within the Nostocales (cyanobacteria). Harmful Algae. 54:21-43.

Costa I, Azevedo S, Senna P, Bernardo R, Costa S, Chellappa N (2006). Occurrence of toxin-producing cyanobacteria blooms in a Brazilian semiarid reservoir. Braz J Biol. 66:211-219.

Devlin J, Edwards O, Gorham P, Hunter N, Pike R, Stavric B (1977). Anatoxin-a, a toxic alkaloid from Anabaena flos-aquae NRC-44h. Can J Chem. 55:1367-1371.

Dias E, Pereira P, Franca S (2002). Production of paralytic shellfish toxins by Aphanizomenon sp LMECYA 31 (cyanobacteria). J Phycol. 38:705-712.

Dittmann E, Fewer DP, Neilan BA (2013). Cyanobacterial toxins: biosynthetic routes and evolutionary roots. FEMS Microbiol Rev. 37:23-43.

Dörr FA, Rodríguez V, Molica R, Henriksen P, Krock B, Pinto E (2010). Methods for detection of anatoxin-a (s) by liquid chromatography coupled to electrospray ionization-tandem mass spectrometry. Toxicon. 55:92-99.

Draisci R, Ferretti E, Palleschi L, Marchiafava C (2001). Identification of anatoxins in blue-green algae food supplements using liquid chromatography-tandem mass spectrometry. Food Addit Contam. 18:525-531.

Echenique-Subiabre I, Tenon M, Humbert J-F, Quiblier C (2018). Spatial and temporal variability in the development and potential toxicity of Phormidium biofilms in the Tarn River, France. Toxins. 10:418.

Faassen EJ, Harkema L, Begeman L, Lurling M (2012). First report of (homo) anatoxin-a and dog neurotoxicosis after ingestion of benthic cyanobacteria in The Netherlands. Toxicon. 60:378-384.

Fastner J, Beulker C, Geiser B, Hoffmann A, Kröger R, Teske K et al. (2018). Fatal neurotoxicosis in dogs associated with tychoplanktic, anatoxin-a producing Tychonema sp. in mesotrophic Lake Tegel, Berlin. Toxins. 10:60.

Fawell JK, Mitchell RE, Hill RE, Everett DJ (1999). The toxicity of cyanobacterial toxins in the mouse: II Anatoxin-a. Human Exp Toxicol. 18:168-173.

Ferreira FM, Soler JMF, Fidalgo ML, Fernández-Vila P (2001). PSP toxins from Aphanizomenon flos-aquae (cyanobacteria) collected in the Crestuma-Lever reservoir (Douro river, northern Portugal). Toxicon 39:757-761.

Foss AJ, Phlips EJ, Yilmaz M, Chapman A (2012). Characterization of paralytic shellfish toxins from Lyngbya wollei dominated mats collected from two Florida springs. Harmful Algae. 16:98-107.

Fristachi A, Sinclair JL (2008). Occurrence of cyanobacterial harmful algal blooms workgroup report. In: Hudnell HK, editors: Cyanobacterial harmful algal blooms: state of the science and research needs. New York: Springer:45-103. 
Funari E, Testai E (2008). Human health risk assessment related to cyanotoxins exposure. Crit Rev Toxicol. 38:97-125.

Furey A, Crowley J, Shuilleabhain AN, Skulberg AM, James KJ (2003). The first identification of the rare cyanobacterial toxin, homoanatoxin-a, in Ireland. Toxicon. 41:297-303.

Gagnon A, Pick FR (2012). Effect of nitrogen on cellular production and release of the neurotoxin anatoxin-a in a nitrogen-fixing cyanobacterium. Front Microbiol. 3:211.

Gallon JR, Kittakoop P, Brown EG (1994). Biosynthesis of anatoxin-a by Anabaena flosaquae: examination of primary enzymic steps. Phytochemistry. 35:1195-1203.

Ghassempour A, Najafi NM, Mehdinia A, Davarani SSH, Fallahi M, Nakhshab M (2005). Analysis of anatoxin-a using polyaniline as a sorbent in solidphase microextraction coupled to gas chromatography-mass spectrometry. J Chromatogr A. 1078:120-127.

Grachev M, Zubkov I, Tikhonova I, Ivacheva M, Kuzmin A, Sukhanova E et al. (2018). Extensive contamination of water with saxitoxin near the dam of the Irkutsk hydropower station reservoir (East Siberia, Russia). Toxins. 10:402.

Gugger MF, Lenoir S, Berger C, Ledreux A, Druart JC, Humbert JF et al. (2005). First report in a river in France of the benthic cyanobacterium Phormidium favosum producing anatoxin-a associated with dog neurotoxicosis. Toxicon. 45:919-928.

Harada K-I, Nagai H, Kimura Y, Suzuki M, Park H-D, Watanabe MF et al. (1993). Liquid chromatography/mass spectrometric detection of anatoxin-a, a neurotoxin from cyanobacteria. Tetrahedron. 49:9251-9260.

Harland FM, Wood SA, Moltchanova E, Williamson WM, Gaw S (2013). Phormidium autumnale growth and anatoxin-a production under iron and copper stress. Toxins. 5:2504-2521.

Heath MW, Wood SA, Barbieri RF, Young RG, Ryan KG (2014). Effects of nitrogen and phosphorus on anatoxin-a, homoanatoxin-a, dihydroanatoxin-a and dihydrohomoanatoxin-a production by Phormidium autumnale. Toxicon. 92:179-185.

Henriksen P, Carmichael WW, An JS, Moestrup O (1997). Detection of an anatoxina(s)-like anticholinesterase in natural blooms and cultures of Cyanobacteria/ blue-green algae from Danish lakes and in the stomach contents of poisoned birds. Toxicon. 35:901-913.

Hilborn ED, Roberts VA, Backer L, DeConno E, Egan JS, Hyde JB et al. (2014). Algal bloom-associated disease outbreaks among users of freshwater lakes-United States, 2009-2010. Morb Mortal Wkly Rep. 63:11-15.

Humpage A, Rositano J, Bretag A, Brown R, Baker P, Nicholson B et al. (1994). Paralytic shellfish poisons from Australian cyanobacterial blooms. Mar Freshwat Res. 45:761-771.

Humpage AR (2008). Toxin types, toxicokinetics and toxicodynamics. In: H.K. Hudnell, editor: Proceedings of the Interagency, International Symposium on Cyanobacterial Harmful Algal Blooms (ISOC_HAB): Cyanobacterial harmful algal blooms: State of the science and research needs. New York, USA: Springer:383-415.

James KJ, Crowley J, Hamilton B, Lehane M, Skulberg O, Furey A (2005). Anatoxins and degradation products, determined using hybrid quadrupole time-of-flight and quadrupole ion-trap mass spectrometry: forensic investigations of cyanobacterial neurotoxin poisoning. Rapid Commun Mass Spectrom. 19:1167-1175. 
James KJ, Sherlock IR, Stack MA (1997). Anatoxin-a in Irish freshwater and cyanobacteria, determined using a new fluorimetric liquid chromatographic method. Toxicon. 35:963-971.

Jiang Y, Song G, Pan Q, Yang Y, Li R (2015). Identification of genes for anatoxin-a biosynthesis in Cuspidothrix issatschenkoi. Harmful Algae. 46:43-48.

Kaas H, Henriksen P (2000). Saxitoxins (PSP toxins) in Danish lakes. Water Res. 34:2089-2097.

Kaminski A, Bober B, Lechowski Z, Bialczyk J (2013). Determination of anatoxin-a stability under certain abiotic factors. Harmful Algae. 28:83-87.

Kiviranta J, Sivonen K, Lahti K, Luukkainen R, Niemelä SI (1991). Production and biodegradation of cyanobacterial toxins - a laboratory study. Arch Hydrobiol. 121:281-294.

Kormas KA, Lymperopoulou DS (2013). Cyanobacterial toxin degrading bacteria: who are they? BioMed Res Int. 2013: 463894.

Kotut K, Ballot A, Krienitz L (2006) Toxic cyanobacteria and their toxins in standing waters of Kenya: implications for water resource use. J Water Health. 4:233-245.

Krienitz L, Ballot A, Kotut K, Wiegand C, Putz S, Metcalf JS et al. (2003). Contribution of hot spring cyanobacteria to the mysterious deaths of Lesser Flamingos at Lake Bogoria, Kenya. FEMS Microbiol Ecol. 43:141-148.

Lagos N, Onodera H, Zagatto PA, Andrinolo D, Azevedo SMFO, Oshima I (1999). The first evidence of paralytic shellfish toxins in the freshwater cyanobacterium Cylindrospermopsis raciborskii, isolated from Brazil. Toxicon. 37:1359-1373.

Li R, Carmichael WW, Pereira P (2003). Morphological and 16s rRNA gene evidence for reclassification of the paralytic shellfish toxin producing Aphanizomenon flos-aquae LMECYA 31 as Aphanizomenon issatschenkoi (Cyanophyceae). J Phycol. 39:814-818.

Liu Y, Chen W, Li D, Shen Y, Li G, Liu Y (2006a). First report of aphantoxins in China - waterblooms of toxigenic Aphanizomenon flos-aquae in Lake Dianchi. Ecotoxicol Environ Safety. 65:84-92.

Liu Y, Chen W, Li D, Shen Y, Liu Y, Song L (2006b). Analysis of Paralytic Shelfish Toxins in Aphanizomenon DC-1 from Lake Dianchi, China. Environ Toxicol. 21:289-295.

Lopes VM, Baptista M, Repolho T, Rosa R, Costa PR (2014). Uptake, transfer and elimination kinetics of paralytic shellfish toxins in common octopus (Octopus vulgaris). Aquat Toxicol. 146:205-211.

Mahmood NA, Carmichael WW (1986). Paralytic shellfish poisons produced by the freshwater cyanobacterium Aphanizomenon flos-aquae NH-5. Toxicon. 24:175-186.

Mann Sp, Lombard Brr, Loew D, Méjean A, Ploux O (2011). Insights into the reaction mechanism of the prolyl-acyl carrier protein oxidase involved in anatoxin-a and homoanatoxin-a biosynthesis. Biochemistry. 50:7184-7197.

Matsunaga S, Moore RE, Niemczura WP, Carmichael WW (1989). Anatoxin-a (s), a potent anticholinesterase from Anabaena flos-aquae. J Am Chem Soc. 111:8021-8023.

Mazur H, Plinski M (2003). Nodularia spumigena blooms and the occurrence of hepatotoxin in the Gulf of Gdańsk. Oceanologia. 45:305-316. 
Méjean A, Mann S, Maldiney T, Vassiliadis G, Lequin O, Ploux O (2009). Evidence that biosynthesis of the neurotoxic alkaloids anatoxin-a and homoanatoxin-a in the cyanobacterium Oscillatoria PCC 6506 occurs on a modular polyketide synthase initiated by L-proline. J Am Chem Soc. 131:7512-7513.

Méjean A, Paci G, Gautier V, Ploux O (2014). Biosynthesis of anatoxin-a and analogues (anatoxins) in cyanobacteria. Toxicon. 91:15-22.

Méjean A, Peyraud-Thomas C, Kerbrat AS, Golubic S, Pauillac S, Chinain M et al. (2010). First identification of the neurotoxin homoanatoxin-a from mats of Hydrocoleum lyngbyaceum (marine cyanobacterium) possibly linked to giant clam poisoning in New Caledonia. Toxicon. 56:829-835.

Moustaka-Gouni M, Hiskia A, Genitsaris S, Katsiapi M, Manolidi K, Zervou S-K et al. (2017). First report of Aphanizomenon favaloroi occurrence in Europe associated with saxitoxins and a massive fish kill in Lake Vistonis, Greece. Mar Freshwater Res. 68:793-800.

Namikoshi M, Murakami T, Fujiwara T, Nagai H, Niki T, Harigaya E et al. (2004). Biosynthesis and transformation of homoanatoxin-a in the cyanobacterium Raphidiopsis mediterranea Skuja and structures of three new homologues. Chem Res Toxicol. 17:1692-1696.

Negri AP, Jones GJ (1995). Bioaccumulation of paralytic shellfish poisoning (PSP) toxins from the cyanobacterium Anabaena circinalis by the freshwater mussel Alathyria condola. Toxicon. 33:667-678.

Neilan BA, Pearson LA, Muenchhoff J, Moffitt MC, Dittmann E (2013). Environmental conditions that influence toxin biosynthesis in cyanobacteria. Environ Microbiol. 15:1239-1253.

Osswald J, Azevedo J, Vasconcelos V, Guilhermino L (2011). Experimental determination of the bioconcentration factors for anatoxin-a in juvenile rainbow trout (Oncorbynchus mykiss). Proc Int Acad Ecol Environ Sci. 1:77.

Osswald J, Rellán S, Gago A, Vasconcelos V (2007). Toxicology and detection methods of the alkaloid neurotoxin produced by cyanobacteria, anatoxin-a. Environ Int. 33:1070-1089.

Osswald J, Rellan S, Gago A, Vasconcelos V (2008). Uptake and depuration of anatoxin-a by the mussel Mytilus galloprovincialis (Lamarck, 1819) under laboratory conditions. Chemosphere. 72:1235-1241.

Park HD, Watanabe MF, Harada K-I, Nagai H, Suzuki M, Watanabe M et al. (1993). Hepatotoxin (Microcystin) and neurotoxin (Anatoxin-a) contained in natural blooms and strains of cyanobacteria from Japanese freshwaters. Nat Toxins. 1:353-360.

Pearson LA, Dittmann E, Mazmouz R, Ongley SE, D’Agostino PM, Neilan BA (2016). The genetics, biosynthesis and regulation of toxic specialized metabolites of cyanobacteria. Harmful Algae. 54:98-111.

Pereira P, Li RH, Carmichael WW, Dias E, Franca S (2004). Taxonomy and production of paralytic shellfish toxins by the freshwater cyanobacterium Aphanizomenon gracile LMECYA40. Europ J Phycol. 39:361-368.

Pereira P, Onodera H, Andrinolo D, Franca S, Araujo F, Lagos N et al. (2000). Paralytic shellfish toxins in the freshwater cyanobacterium Aphanizomenon flos-aquae, isolated from Montargil reservoir, Portugal. Toxicon. 38:1689-1702.

Pereyra JP, D‘Agostino PM, Mazmouz R, Woodhouse JN, Pickford R, Jameson I et al. (2017). Molecular and morphological survey of saxitoxin-producing 
cyanobacterium Dolichospermum circinale (Anabaena circinalis) isolated from geographically distinct regions of Australia. Toxicon. 138:68-77.

Pomati F, Sacchi S, Rossetti C, Giovannardi S, Onodera H, Oshima Y et al. (2000). The freshwater cyanobacterium Planktothrix sp. FP1: molecular identification and detection of paralytic shellfish poisoning toxins. J Phycol. 36:553-562.

Puddick J, van Ginkel R, Page CD, Murray JS, Greenhough HE, Bowater J et al. (2021) Acute toxicity of dihydroanatoxin-a from Microcoleus autumnalis in comparison to anatoxin-a. Chemosphere. 263:127-937.

Puschner B, Hoff B, Tor ER (2008). Diagnosis of anatoxin-a poisoning in dogs from North America. J Vet Diagn Invest. 20:89-92.

Rantala-Ylinen A, Känä S, Wang H, Rouhiainen L, Wahlsten M, Rizzi E et al. (2011). Anatoxin-a synthetase gene cluster of the cyanobacterium Anabaena sp. strain 37 and molecular methods to detect potential producers. Appl Environ Microbiol. 77:7271-7278.

Rapala J, Lahti K, Sivonen K, Niemelä SI (1994). Biodegradability and adsorption on lake sediments of cyanobacterial hepatotoxins and anatoxin-a. Lett Appl Microbiol. 19:423-428.

Rapala J, Robertson A, Negri AP, Berg KA, Tuomi P, Lyra C et al. (2005). First report of saxitoxin in Finnish lakes and possible associated effects on human health. Environ Toxicol. 20:331-340.

Rapala J, Sivonen K (1998). Assessment of environmental conditions that favor hepatotoxic and neurotoxic Anabaena spp. strains cultured under light limitation at different temperatures. Microb Ecol. 36:181-192.

Rapala J, Sivonen K, Luukkainen R, Niemelä SI (1993). Anatoxin-a concentration in Anabaena and Aphanizomenon under different environmental conditions and comparison of growth by toxic and non-toxic Anabaena-strains - a laboratory study. J Appl Phycol. 5:581-591.

Rellán S, Osswald J, Saker M, Gago-Martinez A, Vasconcelos V (2009). First detection of anatoxin-a in human and animal dietary supplements containing cyanobacteria. Food Chem Toxicol. 47:2189-2195.

Rogers E, Hunter E, Moser V, Phillips P, Herkovits J, Munoz L et al. (2005). Potential developmental toxicity of anatoxin-a, a cyanobacterial toxin. J Appl Toxicol. 25:527-534.

Salmaso N, Cerasino L, Boscaini A, Capelli C (2016). Planktic Tychonema (Cyanobacteria) in the large lakes south of the Alps: phylogenetic assessment and toxigenic potential. FEMS Microbiol Ecol. 92:fiw155.

Selwood AI, Holland PT, Wood SA, Smith KF, Mcnabb PS (2007). Production of anatoxin-a and a novel biosynthetic precursor by the cyanobacterium Aphanizomenon issatschenkoi. Environ Sci Technol. 41:506-510.

Shams S, Capelli C, Cerasino L, Ballot A, Dietrich DR, Sivonen K et al. (2015). Anatoxin-a producing Tychonema (Cyanobacteria) in European waterbodies. Water Res. 69:68-79.

Shih PM, Wu D, Latifi A, Axen SD, Fewer DP, Talla E et al. (2013). Improving the coverage of the cyanobacterial phylum using diversity-driven genome sequencing. Proc Natl Acad Sci USA. 110:1053-1058.

Sivonen K, Himberg K, Luukkainen R, Niemelä S, Poon G, Codd G (1989). Preliminary characterization of neurotoxic cyanobacteria blooms and strains from Finland. Environ Toxicol. 4:339-352. 
Skulberg OM, Carmichael WW, Andersen RA, Matsunaga S, Moore RE, Skulberg R (1992). Investigations of a neurotoxic oscillatorialean strain (Cyanophyceae) and its toxin. Isolation and characterization of homoanatoxin-a. Environ Toxicol Chem. 11:321-329.

Smith R, Lewis D (1987). A rapid analysis of water for anatoxin a, the unstable toxic alkaloid from Anabaena flos-aquae, the stable non-toxic alkaloids left after bioreduction and a related amine which may be nature's precursor to anatoxin a. Vet Human Toxicol. 29:153-154.

Stevens D, Krieger R (1991). Stability studies on the cyanobacterial nicotinic alkaloid anatoxin-A. Toxicon. 29:167-179.

Tango PJ, Butler W (2008). Cyanotoxins in tidal waters of Chesapeake Bay. Northeastern Nat. 15:403-416.

Testai E, Scardala S, Vichi S, Buratti FM, Funari E (2016). Risk to human health associated with the environmental occurrence of cyanobacterial neurotoxic alkaloids anatoxins and saxitoxins. Crit Rev Toxicol. 46:385-419.

Trainer VL, Hardy FJ (2015). Integrative monitoring of marine and freshwater harmful algae in Washington State for public health protection. Toxins. 7:1206-1234.

Velzeboer RM, Baker PD, Rositano J, Heresztyn T, Codd GA, Raggett SL (2000). Geographical patterns of occurrence and composition of saxitoxins in the cyanobacterial genus Anabaena (Nostocales, Cyanophyta) in Australia. Phycologia. 39:395-407.

Watanabe MF, Tsujimura S, Oishi S, Niki T, Namikoshi M (2003). Isolation and identification of homoanatoxin-a from a toxic strain of the cyanobacterium Raphidiopsis mediterranea Skuja isolated from Lake Biwa, Japan. Phycologia. 42:364-369.

WHO (2003). Guidelines for safe recreational water environments. Vol. 1: Coastal and fresh waters. Geneva: World Health Organization. https://apps.who.int/ iris/handle/10665/42591

WHO (2020). Cyanobacterial toxins: Anatoxin-a and analogues. Background document for development of WHO Guidelines for Drinking-water Quality and Guidelines for Safe Recreational Water Environments. Geneva: World Health Organization. https://apps.who.int/iris/handle/10665/338060

Wonnacott S, Jackman S, Swanson K, Rapoport H, Albuquerque E (1991). Nicotinic pharmacology of anatoxin analogs. II. Side chain structure-activity relationships at neuronal nicotinic ligand binding sites. J Pharmacol Exp Therap. 259:387-391.

Wonnacott S, Swanson K, Albuquerque E, Huby N, Thompson P, Gallagher T (1992). Homoanatoxin: a potent analogue of anatoxin-a. Biochem Pharmacol. 43:419-423.

Wood SA, Holland PT, MacKenzie L (2011). Development of solid phase adsorption toxin tracking (SPATT) for monitoring anatoxin-a and homoanatoxin-a in river water. Chemosphere. 82:888-894.

Wood SA, Puddick J, Fleming RC, Heussner AH (2017). Detection of anatoxinproducing Phormidium in a New Zealand farm pond and an associated dog death. New Zeal J Botany. 55:36-46.

Wood SA, Rasmussen JP, Holland PT, Campbell R, Crowe ALM (2007a). First report of the cyanotoxin anatoxin-A from Aphanizomenon issatschenkoi (cyanobacteria). J Phycol. 43:356-365. 
Wood SA, Selwood AI, Rueckert A, Holland PT, Milne JR, Smith KF et al. (2007b). First report of homoanatoxin-a and associated dog neurotoxicosis in New Zealand. Toxicon. 50:292-301.

Wood SA, Smith FM, Heath MW, Palfroy T, Gaw S, Young RG et al. (2012). Withinmat variability in anatoxin-a and homoanatoxin-a production among benthic Phormidium (cyanobacteria) strains. Toxins. 4:900-912.

Yilmaz M, Foss AJ, Selwood AI, Özen M, Boundy M (2018). Paralytic shellfish toxin producing Aphanizomenon gracile strains isolated from Lake Iznik, Turkey. Toxicon. 148:132-142. 


\subsection{SAXITOXINS OR PARALYTIC SHELLFISH POISONS}

\section{Emanuela Testai}

Saxitoxins (STXs) are natural alkaloids also known as paralytic shellfish poisons (PSP) because they were originally found in molluscs, the consumption of which led to poisonings of humans. The organisms producing this group of toxins are marine microalgae - dinoflagellates of the genera Alexandrium, Gymnodinium and Pyrodinium - as well as freshwater cyanobacteria.

\subsection{Chemical structures}

Saxitoxins, also known as paralytic shellfish poisoning toxins, are a family of 57 analogues (Wiese et al., 2010), consisting of a tetrahydropurine group and two guanidine subunits, representing the tricyclic perhydropurine backbone. Depending on the substitutions in the variable positions, R1-R4, the family can be subdivided into four groups:

1. nonsulphated molecules whose structure is similar to carbamates, including saxitoxins and neosaxitoxin (STX, dcSTX, neoSTX);

2. monosulphated gonyautoxins (GTX 1 to 6 and dcGTX 2 and 3);

3. doubly-sulphated C-toxins (C1-2);

4. variants identified exclusively in strains of Lyngbya (Microseira) wollei (LWTX 1-6) from the USA (Lajeunesse et al., 2012), characterised by the presence of a hydrophobic side chain with an acetate at C13 (LWTX 1-3, 5, 6) and a carbinol at C12 (LWTX 2, 3, 5) instead of a hydrated ketone.

Alternatively, they are grouped on the basis of the R4 substituent into carbamate toxins (STX, neoSTX and GTX1-4), sulphamate toxins (GTX 5-6, C1-4) and decarbamoyl toxins (dcSTX, dcneoSTX and dcGTX1-4) (Figure 2.4, Table 2.8).

Most known STXs are hydrophilic, with the exception of those produced by $L . w o l l e i$ in a freshwater environment.

Interconversions among the different STX congeners have been reported, both chemically and enzymatically mediated, and in some cases, this is expected to increase toxicity. Some of the transformations include desulphation (Ben-Gigirey \& Villar-González, 2008), oxidation (García et al., 2010), reduction (Oshima, 1995a; Fast et al., 2006), decarbamoylation (Oshima, 1995a; Fast et al., 2006), deacetylation (Foss et al., 2012) and epimerisation (Ben-Gigirey \& Villar-González, 2008). 
(a)

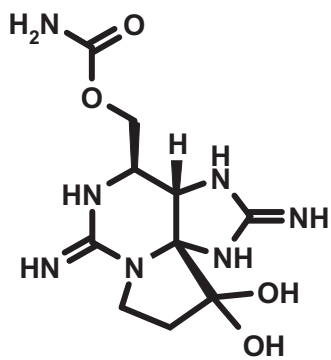

(b)

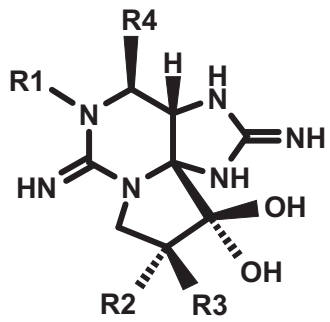<smiles>[R4]COC(=O)NS(=O)(=O)O</smiles>

R4-3: $\mathrm{CH}_{2}-\mathrm{OH}$

R4-4: $\mathrm{CH}_{3}$

Figure 2.4 Structure of saxitoxin (a) and general structure of saxitoxins (STX) and gonyautoxins (GTX) (b). R4-I: carbamate toxins, including STX and neo-saxitoxin; R4-2: N-sulphocarbamoyl (or sulphamate) toxins, including GTX5 and GTX6; R4-3 decarbamoyl toxins, including dcSTX; R4-4: deoxydecarbamoyl toxins, including deoxydecarbamoyl-STX. For RI, R2 and R3 in particular variants, see Table 2.8 .

\subsubsection{Toxicity: mode of action}

The toxic effects of saxitoxin (STX), summarised in the following, are described in detail in the WHO Background Document on Saxitoxins (WHO, 2020; see there for further information and references). The great majority of reported clinical, epidemiological and toxicological data about STXs have been obtained from cases of poisoning following the consumption of shellfish which accumulate STXs produced by marine dinoflagellates; however, since the chemical structure is the same as that of the STXs produced by cyanobacteria, the toxicological profile is identical. Saxitoxins are readily absorbed by the gastrointestinal tract, rapidly distributed to a range of tissues, including the central nervous system, and undergo rapid excretion mainly in the urine as glucuronides, thus suggesting glucuronidation as a possible detoxication metabolic pathway in animals and humans.

The mechanism of action of STXs is based on Na-channel blocking in neuronal cells and on $\mathrm{Ca}^{++}$and $\mathrm{K}^{+}$channel blocking in cardiac cells. This action prevents the propagation of electrical transmission within the peripheral nerves and skeletal or cardiac muscles. It leads to typical neurologic symptoms such as nervousness, twitching, ataxia, convulsions and muscle and respiratory paralysis, and at a lethal dose, death in animal experiments has been observed within a few minutes; for humans, death through respiratory paralysis has been reported after $2-24 \mathrm{~h}$ (FAO, 2004). Depending on the variants, STX toxicity in mice can differ considerably. Carbamate toxins are by far the more toxic and the lack of the carbamoyl group side 
Table 2.8 Different saxitoxin-like congeners and their relative toxicity compared to STX (relative toxicity $=\mathrm{I}$ )

\begin{tabular}{|c|c|c|c|c|c|}
\hline & $R I$ & $R 2$ & $R 3$ & $\begin{array}{l}\text { Relative } \\
\text { toxicity }\end{array}$ & Reference \\
\hline \multicolumn{6}{|c|}{ Carbamate toxins } \\
\hline STX & $\mathrm{H}$ & $\mathrm{H}$ & $\mathrm{H}$ & I & Oshima (1995b) \\
\hline neo STX & $\mathrm{OH}$ & $\mathrm{H}$ & $\mathrm{H}$ & 0.93 & Oshima (1995b) \\
\hline GTXI & $\mathrm{OH}$ & $\mathrm{H}$ & $\mathrm{OSO}_{3}^{-}$ & 0.99 & Oshima (1995b) \\
\hline GTX2 & $\mathrm{H}$ & $\mathrm{H}$ & $\mathrm{OSO}_{3}^{-}$ & 0.41 & Wichmann et al. (198I) \\
\hline GTX3 & $\mathrm{H}$ & $\mathrm{OSO}_{3}^{-}$ & $\mathrm{H}$ & 0.90 & Genenah \& Shimizu (I98I) \\
\hline GTX4 & $\mathrm{OH}$ & $\mathrm{OSO}_{3}^{-}$ & $\mathrm{H}$ & 0.73 & Oshima (1995b) \\
\hline \multicolumn{6}{|c|}{ Sulphamate toxins } \\
\hline GTX5 & $\mathrm{H}$ & $\mathrm{H}$ & $\mathrm{H}$ & 0.15 & Genenah \& Shimizu (I98I) \\
\hline GTX6 & $\mathrm{OH}$ & $\mathrm{H}$ & $\mathrm{H}$ & 0.07 & Oshima et al. (1989) \\
\hline $\mathrm{Cl}$ & $\mathrm{H}$ & $\mathrm{H}$ & $\mathrm{OSO}_{3}^{-}$ & 0.01 & Wichmann et al. (198I) \\
\hline $\mathrm{C} 2$ & $\mathrm{H}$ & $\mathrm{OSO}_{3}^{-}$ & $\mathrm{H}$ & 0.17 & Oshima et al. (1989) \\
\hline $\mathrm{C} 3$ & $\mathrm{OH}$ & $\mathrm{H}$ & $\mathrm{OSO}_{3}^{-}$ & 0.01 & Oshima (1995b) \\
\hline $\mathrm{C} 4$ & $\mathrm{OH}$ & $\mathrm{OSO}_{3}^{-}$ & $\mathrm{H}$ & 0.06 & Oshima (1995b) \\
\hline \multicolumn{6}{|c|}{ Decarbamoyl toxins } \\
\hline dcSTX & $\mathrm{H}$ & $\mathrm{H}$ & $\mathrm{H}$ & 0.51 & Oshima (1995b) \\
\hline deneoSTX & $\mathrm{OH}$ & $\mathrm{H}$ & $\mathrm{H}$ & n.a. & \\
\hline dcGTXI & $\mathrm{OH}$ & $\mathrm{H}$ & $\mathrm{OSO}_{3}^{-}$ & n.a. & \\
\hline dcGTX2 & $\mathrm{H}$ & $\mathrm{H}$ & $\mathrm{OSO}_{3}^{-}$ & 0.65 & Oshima (1995b) \\
\hline dcGTX3 & $\mathrm{H}$ & $\mathrm{OSO}_{3}^{-}$ & $\mathrm{H}$ & 0.75 & Oshima (1995b) \\
\hline dcGTX4 & $\mathrm{OH}$ & $\mathrm{OSO}_{3}^{-}$ & $\mathrm{H}$ & 0.49 & Oshima (1995b) \\
\hline
\end{tabular}

Where more than one value for i.p. acute toxicity was available for an individual toxin, highest acute toxicity was considered to calculate the relative toxicity. Toxicity of saxitoxins is generally expressed in mouse units (MU), that is, the amount injected toxin which would kill a $20 \mathrm{~g}$ mouse in $15 \mathrm{~min}$ and is equivalent to $0.18 \mu \mathrm{g}$ of STX.

n.a.not available. RI, R2 and R3 refer to the substituent groups as depicted in Figure 2.4.

chain gives rise to a molecule with about $60 \%$ of the original toxic activity, whereas C-toxins and LWTXs are characterised by a much lower toxicity.

No robust information on repeated toxicity, genotoxicity, carcinogenicity and reproductive or developmental toxicity is available.

Doses in the range 140-300 $\mathrm{mg}$ STXeq/person were reported to induce no or mild symptoms, but variability is pronounced; a case report indicated that $\approx 300 \mu \mathrm{g}$ PSP toxin per person may be fatal (FAO, 2004). Mild clinical symptoms (tingling sensation or numbness around lips, gradually spreading to the face and neck) have a quick onset (hours), but may last for days. These symptoms precede prickly sensation in the fingertips and toes, headaches, 
dizziness, nausea, vomiting and diarrhoea, and distinct muscular weakness. A broad spectrum of effects, from mild to moderate symptoms up to paralysis and death, have been described following ingestions of 460-12 $400 \mu \mathrm{g}$ STXeq/person (FAO, 2004; McLaughlin et al., 2011). This high variability has been attributed to uncertainties in the detection of the actual level of exposure to different STX variants, differences in critical access to rapid health care and differences in individual susceptibility.

\subsubsection{Derivation of guideline values}

The following section is taken directly from the WHO chemicals background document on saxitoxins (WHO, 2020) which discusses the considerations for the derivation of provisional guideline values for exposure to saxitoxin in more detail. The GV for acute exposure through drinking-water is derived for bottle-fed infants, as the most sensitive subgroup in a population. This is considered appropriate for this cyanotoxin group because the GV is for acute exposure, and there is a relatively small margin of safety, as described below. All other default assumptions were applied as described in WHO $(2009,2017)$ for deriving the acute drinking-water GV, and in WHO (2003) for deriving the recreational GV.

FAO (2004) identified a LOAEL for mild symptoms of $2.0 \mu \mathrm{g} / \mathrm{kg}$ bw, based on a review of human cases of paralytic shellfish poisoning (PSP). More recently, EFSA (2009) reviewed about 500 cases of human PSP described in case reports that had estimated the consumption of STXs associated with a range of symptoms. This analysis identified a LOAEL for STXeq of $1.5 \mu \mathrm{g} / \mathrm{kg}$ bw by assuming an adult body weight of $60 \mathrm{~kg}$. Because many individuals did not show symptoms at much higher estimated intakes, EFSA (2009) reasoned that the LOAEL must be very near the threshold for effects in sensitive individuals. Therefore an uncertainty factor of 3 was applied to the LOAEL "to estimate a NOAEL", establishing an acute reference dose (ARfD) for STXeq of $0.5 \mu \mathrm{g} / \mathrm{kg}$ bw. An uncertainty factor for intraspecies variation was not applied because documented human cases included a wide spectrum of people (occupation, age, and sex).

The GVs are derived from data from poisoning events caused by mixtures of STXs, with total STXs expressed as STX concentration equivalents (STXeq). The GVs therefore apply to total STXs in a sample, not just the parent compound, STX.

These values are supported by data from animal studies: the use of the lowest acute no observed adverse effect level (NOAEL) for neoSTX of $87 \mu \mathrm{g} / \mathrm{kg}$ bw after gavage administration as a point of departure leads to the derivation of an ARfD for neoSTX of $0.87 \mu \mathrm{g} / \mathrm{kg}$ bw (applying an uncertainty factor of 100). This value is of the same order of magnitude as the reference values obtained with human data (Testai et al., 2016). 


\section{Calculation of acute drinking-water guideline value for saxitoxins}

$$
\mathrm{GV}_{\text {acute }}=\frac{\text { LOAEL }^{*} \mathrm{bw} * P}{\mathrm{UF} * \mathrm{C}}=\frac{1.5 * 5 * 1.0}{3 * 0.75} \mu \mathrm{g} / \mathrm{L}=3.3 \mu \mathrm{g} / \mathrm{L} \approx 3 \mu \mathrm{g} / \mathrm{L}
$$

where

$\mathrm{GV}_{\text {acute }}=$ guideline value for acute exposure

LOAEL $=$ lowest-observed-adverse-effect level $(1.5 \mu \mathrm{g} \mathrm{STXeq} / \mathrm{kg}$, based on the human data on PSP reports)

$\mathrm{bw}=$ body weight (default $=5 \mathrm{~kg}$ for an infant)

$\mathrm{P}=$ fraction of exposure allocated to drinking-water (default for shortterm exposure $=100 \%$, considering that drinking-water is expected to be the most likely source of exposure where surface water is used as the source of drinking-water)

$\mathrm{UF}=$ uncertainty factor $(3$, for use of a LOAEL rather than a NOAEL)

$\mathrm{C}=$ daily drinking-water consumption (default $=750 \mathrm{~mL}$ for an infant).

\section{Calculation of recreational water guideline value for saxitoxin}

The calculation is based on a scenario of a child playing in bloom-infested water:

$$
\mathrm{GV}_{\text {recreation }}=\frac{\mathrm{LOAEL}^{*} \mathrm{bw}}{\mathrm{UF}^{*} \mathrm{C}}=\frac{1.5 * 15}{3 * 0.25} \mu \mathrm{g} / \mathrm{L}=30 \mu \mathrm{g} / \mathrm{L}
$$

where

$\mathrm{GV}_{\text {recreation }}=$ guideline value for recreational exposure

LOAEL = lowest observed-adverse-effect level $(1.5 \mu \mathrm{g} \mathrm{STXeq} / \mathrm{kg}$, based on human poisoning data)

bw $=$ body weight $($ default $=15 \mathrm{~kg}$ for a child $)$

$\mathrm{UF}=$ uncertainty factor $(3$, for use of a LOAEL rather than a NOAEL)

$\mathrm{C}=$ daily incidental water consumption (default $=250 \mathrm{~mL}$ for a child).

\section{Considerations in applying the provisional guideline values}

As indicated above, for assessing risk, the cumulative detection of both STX and its structural analogues should be evaluated against the GVs. 
This is generally expressed as STXeq. STXeq can indicate concentration equivalents - calculated by simple addition of the concentrations of all analogues present, each being quantified against an analytical standard for that analogue. This represents a conservative approach to protect human health in most cases, assuming that all analogues have comparable characteristics and toxicity to STX. An exception is when the more potent neoSTX is the dominant congener present (see below). A more precise, usually less conservative approach is to determine STX toxicity equivalents by multiplying the concentration of each analogue by the respective toxicity equivalence factor (TEF) before addition. Where available, oral toxicities should be used in preference to relative i.p. toxicities. Munday et al. (2013) provides the acute oral toxicities of some analogues while a table of TEFs based on i.p. toxicity in mice has been published by EFSA (2009).

The acute GVs for STXs are based on acute exposure data. A time limit for tolerating concentrations up to $3 \mu \mathrm{g} / \mathrm{L}$ cannot be given because of the lack of data on effects at low doses. Thus, in contrast to other cyanotoxins, short-term and lifetime exposure GVs were not developed, and short-term exceedances of the acute GV should not be permitted. Although there is currently no evidence of health impairments from chronic exposure to low doses of STXs, it is always prudent to implement control measures to reduce the presence of toxic cyanobacterial blooms or their impact on drinking-water supplies as soon as possible (see Chapters 6-10). Limited data show that STX concentrations in drinking-water have almost always been at trace levels (see section 2.4.5), indicating that conventional water treatment is generally effective, provided that cell lysis is avoided (see Chapter 10).

The drinking-water GV for STXs uses an allocation factor of $100 \%$ for drinking-water; however, it may be appropriate to consider reducing the allocation factor for drinking-water in locations with increased risk of coincident water and shellfish exposure (marine or freshwater). However, it should be noted that GVs for STX in marine shellfish are comparatively high and, in locations where contamination of shellfish is a concern, drinking-water containing STX would contribute a relatively small additional exposure. Nevertheless, it is recommended that health authorities jointly consider and manage such a scenario, particularly given the relatively steep dose-response relationship for these toxins.

For the drinking-water acute GV, the lower body weight and higher likely water intake of an infant (as a function of body weight) were used because a GV based on adults could allow exposure of infants to a concentration of STXs close to the LOAEL. For a $60 \mathrm{~kg}$ adult consuming $2 \mathrm{~L}$ of drinking-water per day, a 5-fold higher concentration than the acute GV would be tolerable. 


\subsubsection{Production}

\subsubsection{Producing cyanobacteria}

Saxitoxins are produced by species of marine eukaryotic dinoflagellates within the genera Alexandrium, Gymnodinium and Pyrodinium as well as by cyanobacteria within a range of species and strains belonging to the Nostocales, that is, Dolichospermum (Anabaena). (Humpage et al., 1994; Velzeboer et al., 2000), Aphanizomenon (Ikawa et al., 1982; Sasner et al., 1984; Pereira et al., 2000; Dias et al., 2002) and Raphidiopsis (Cylindrospermopsis) raciborskii mainly in Brazil (Lagos et al., 1999; Molica et al., 2002) and Scytonema (Smith et al., 2011) and Oscillatoriales such as Planktothrix and Microseira (Lyngbya) wollei (Carmichael et al., 1997; Onodera et al., 1997). From lakes and reservoirs of the southern USA, Microseira wollei is known to overwinter in the form of benthic mats and rises to form surface mats during the warmer months (Carmichael et al., 1997).

Cyanobium sp. CENA 142 and Oxynema sp. CENA 135 were among 135 strains isolated from cyanobacteria collected from Cardoso Island and Bertioga mangroves for which both molecular analyses and ELISA showed STXs production (Silva et al., 2014). For further details, see the review by Testai et al. (2016) and Cirés and Ballot (2016).

\subsubsection{Toxin profiles}

The production of different STX congeners seems to be strain-specific. Indeed, C1, C2, GTX2 and GTX3 were found as predominant congeners in environmental samples and isolated strains of Dolichospermum circinale in Australia, although a hitherto unique toxin composition (exclusively STX and GTX5) was found in a geographically isolated strain from the southwest coast of Australia (Velzeboer et al., 2000). Ferreira et al. (2001) found that two Aphanizomenon flosaquae strains and samples of a bloom from a reservoir in Portugal contained a specific STX mixture: GTX4 was the dominant analogue, followed by GTX1 and GTX3. A. flosaquae strains in a Chinese lake produced neoSTX, dcSTX and dcGTX3, showing a different toxin profile (Liu et al., 2006a; Liu et al., 2006b), whereas A. gracile strains detected in two German lakes produced GTX5, STX, dcSTX and neoSTX (Ballot et al., 2010).

In Brazilian freshwaters, STXs are attributed to R. raciborskii. In strains isolated from two reservoirs, the contents of total STXs were similar to those reported in D. circinale in Australia (Humpage et al., 1994; Lagos et al., 1999). One of the Brazilian strains showed a toxin profile very similar to that of A. flosaquae, while the other produced only STX and GTX2/3. Other toxin profiles were described for the Tabocas Reservoir in Caruaru (NE Brazil) affected by a $R$. raciborskii bloom; several STX analogues 
(STX, GTX6, dcSTX, neoSTX and dcneoSTX) were identified but no cylindrospermopsin was detected (Molica et al., 2002). Again in Brazil, Castro et al. (2004) reported a $R$. raciborskii strain isolated from a bloom which contained STX concentrations around $0.3 \mathrm{mg} / \mathrm{g} \mathrm{DW}$, which is 4 - to 8 -fold higher than those of GTX2 and GTX3.

In Lyn. wollei strains isolated from a reservoir in southern USA, GTX2 and GTX3 represented the major STX congeners, whereas STX and neoSTX were not detected (Carmichael et al., 1997).

Planktothrix sp. FP1 has been associated with the production of STXs in a lake in Italy, confirmed in the isolated culture; the toxin profile of this strain included STX, GTX2 and GTX3 (Pomati et al., 2000).

Few data have been published on the cellular contents of STXs in different cyanobacteria. Llewellyn et al. (2001) have reported STX cell quota up to slightly more than $450 \mathrm{ng} / 10^{6}$ cells (i.e., $0.45 \mathrm{pg} / \mathrm{cell}$ ) in a D. circinale strain isolated from an Australian waterbody. Hoeger et al. (2005) estimated the cell quota to be $0.12 \mathrm{pg}$ STXs/cell in D. circinale. Higher cell quotas (up to $1300 \mathrm{fg} / \mathrm{cell}$ ) are reported for a strain of Scytonema sp. which, however, has very large cells, and in relation to its biomass, with $119 \mu \mathrm{g} / \mathrm{g}$ dry weight the toxin content of this strain was not exceptionally high (Smith et al., 2011). Cell quota up to $0.034 \mathrm{pg} / \mathrm{cell}$ of STXeq. were reported in an Aphanizomenon sp. (strain LMECYA 31); in the same culture, very high levels of dissolved STXs were observed in the culture media, especially in the late growth phase, very likely as a consequence of cell lysis and leakage (Dias et al., 2002).

Tables 2.6 and 2.7 give examples of the STX contents of strains and environmental samples, respectively. For further details, see reviews by Funari and Testai (2008), Pearson et al. (2016) and Testai et al. (2016).

\subsubsection{Biosynthesis and regulation}

The saxitoxin biosynthesis gene cluster $(s x t)$ was first characterised in Cyl. raciborskii T3 by Kellmann et al. (2008); other characterisations followed from other strains, namely, Dolichospermum circinale AWQC131C, Aphanizomenon sp. NH-5 (Mihali et al., 2009), Raphidiopisis brookii D9 (Stüken et al., 2011) and Lyngbya wollei (Mihali et al., 2011). All five sxt clusters encoded biosynthetic enzymes (sxtA, sxtG, sxtB, sxtD, sxtS, sxtU, $s x t H / T$ and $s x t I$ which appear to have diverse catalytic functions) plus regulatory genes (sxtL, sxt $\mathrm{N}$ and $s x t X)$ and transporters (Kellmann et al., 2008; Pearson et al., 2010).

Different biosynthetic pathways have been proposed, the most recent by D'Agostino et al. (2014) and reviewed by Pearson et al. (2016), starting with the methylation of acetyl-CoA catalysed by SxtA, followed by a condensation reaction with arginine. Further, the aminotransferase SxtG catalyses the addition of the amidino group from a second arginine residue. The 
following reactions are cyclisation and desaturation leading to the tricyclic core structure, resulting in decarbamoyl STX (dcSTX). Finally, a carbamoyl group is added to dcSTX by the carbamoyltransferase SxtI, resulting in the finalised STX molecule.

The N-sulfotransferase (SxtSUL) can modify STX, GTX2 and GTX3, into GTX5-6, C-1 and C-2, by transferring a sulphate residue from PAPS (3'-phosphoadenosine 5'-phosphosulphate) to the carbamoyl group. SxtDIOX is proposed to catalyse the C11 hydroxylation of STX followed by subsequent $\mathrm{O}$-sulphation by SxtSUL for biosynthesis of GTX1-4. A combination of sulphation by SxtSUL and SxtN then leads to biosynthesis of the disulphated C-toxins.

STX congeners are mainly produced during late exponential growth phase in laboratory culture (Neilan et al., 2008). The characterisation of the $s x t$ cluster in several genera has enabled the study of molecular mechanisms underlying regulation, based on the identification of the genes $s x t Y, s x t Z$ and ompR putatively involved in regulating the $s x t$ cluster, adjacent to the Raphidiopsis raciborskii T3 sxt cluster (Kellmann et al., 2008). However, so far the direct involvement of the regulatory cluster on STX biosynthesis has not been experimentally demonstrated (Pearson et al., 2016).

Regarding the impact of environmental factors, the analysis of data from Australian field samples suggests that STX production is influenced by environmental factors, particularly alkalinity $(\mathrm{pH}>8.5)$, very high ammonia concentration ( $>1 \mathrm{mg} / \mathrm{L}$ ) and high conductivity (Neilan et al., 2008). Data from laboratory culture studies further indicate that temperature, culture age, light, $\mathrm{pH}$, salinity and nutrient concentrations affect STX production, although causing a variation of only a $2-4$-fold (Sivonen \& Jones, 1999; Pearson et al., 2016). However, the impact of a particular environmental modulator strictly depends on strains. As an example, toxin production doubled at higher-than-optimal temperatures with Aphanizomenon sp. LMECYA 31 (Dias et al., 2002), but in contrast to this, an increase in toxin content was observed in Aphanizomenon gracile UAM 529 (Casero et al., 2014 ) and $R$. raciborskii C10 (Castro et al., 2004) in response to lowerthan-optimal temperature.

\subsubsection{Occurrence in water environments}

The presence of STX-producing cyanobacterial species has increasingly been published, and they have been found for the first time in many locations, including the Arctic (Kleinteich et al., 2013), New Zealand (Smith et al., 2011), Canada (Lajeunesse et al., 2012) and Europe (Wörmer et al., 2011; Jančula et al., 2014).

Dolichospermum circinale may produce STXs at very high contents (up to $4423 \mu \mathrm{g}$ STXs/g dw). This species caused one of the world's largest 
cyanobacterial blooms, involving more than $1000 \mathrm{~km}$ of the MurrayDarling River, one of Australia's major river systems, with densities of almost $10^{6}$ cells $/ \mathrm{mL}$ (Bowling \& Baker, 1996). Llewellyn et al. (2001) found that 13 out of $14 \mathrm{D}$. circinale strains isolated from Australian freshwaters (rivers, lakes and dams) produced STXs. R. raciborskii is reported to produce similar STX levels in Brazil (Lagos et al., 1999). In Europe, a German survey found STX in 34\% of 29 waterbodies tested (Chorus, 2001), while in Danish and Finnish freshwater bodies dominated by $D$. lemmermannii, STX was found in less than $10 \%$ of samples (Kaas \& Henriksen, 2000; Rapala et al., 2005). Similarly, in 140 lakes in New York State, STXs were detected only in two samples out of nearly 1100 tested, with a maximum concentration of $0.09 \mu \mathrm{g} / \mathrm{L}$, despite the common occurrence of high biomass blooms of A. flosaquae (Boyer, 2008). In Washington State (USA), STXs have been detected in 10 lakes and one pond since 2009, with STX concentrations up to $193 \mu \mathrm{g} / \mathrm{L}$ (Trainer \& Hardy, 2015).

Very little has been published about STX in finished drinking-water. Hoeger et al., (2005) found only traces of STX $(<0.5 \mu \mathrm{g} / \mathrm{L})$ in two out of 52 water samples from two water treatment plants in Queensland, Australia, fed with raw waters affected by cyanobacterial blooms of $D$. circinale, containing up to $17.0 \mu \mathrm{g} / \mathrm{L}$ STX.

\subsubsection{Bioaccumulation}

Marine seafood contaminated with STXs is well known to cause foodborne diseases in humans, highlighting that STXs are passed from phytoplankton to higher trophic levels in the aquatic food web. Marine shellfish bioaccumulate STXs by filter-feeding on STX-producing organisms, and many of them exhibit low sensitivity towards these toxins. STXs also accumulate in fish, predatory mammals such as whales and crabs (Negri \& Jones, 1995) and other non-filter-feeding seafood such as cephalopods, including the common octopus (Octopus vulgaris), the Humboldt squid (Dosidicus gigas) and the Australian octopus (Octopus abdopus) (Lopes et al., 2013). Accumulation generally occurs in the viscera, but in the common octopus and squid, STX accumulated to the greatest extent (390-2680 mg STXeq/ $\mathrm{kg}$ ) in the digestive gland (Lopes et al., 2014), whereas the arms are the preferential site for bioaccumulation in the Australian octopus (up to $246 \mathrm{mg}$ STXeq/100g tissue; Robertson et al. (2004)).

In spite of the importance of this issue for possible human health consequences, information on STX occurrence in freshwater organisms is scarce. Daphnia magna, a relevant organism for STX transfer along the freshwater food web, is able to accumulate STXs when exposed to Cuspidothrix issatschenkoi cells or to lyophilised cyanobacterial material (Nogueira 
et al., 2004). In the laboratory, the Australian freshwater mussel Alathyria condola fed with high densities of neurotoxic D. circinale accumulated STX up to $620 \mu \mathrm{g} / 100 \mathrm{~g}$ of fresh biomass (Negri \& Jones, 1995). Another freshwater mussel, Anodonta cygnea, exposed to high densities of neurotoxic C. issatschenkoi in laboratory experiments accumulated STX to a maximum concentration of $26 \mu \mathrm{g} / 100 \mathrm{~g}$ fresh biomass (Pereira et al., 2004). Accumulation of STXs has also seen in the freshwater bivalves Elliptio camoplanatus and Corbicula fluminea after exposure to A. flosaquae (Sasner et al., 1984).

It has been reported that due to a slow elimination, the surf clam Spisula solidissima can bioaccumulate extremely high quantities of STX (Bricelj et al., 2014). In the clam's marine habitat, the STXs are, however, presumably produced by dinoflagellates rather than by cyanobacteria.

\subsubsection{Environmental fate}

Data on the release of STXs from viable or senescent cyanobacterial cells are lacking. Only a few studies have investigated the chemical breakdown and biodegradation of dissolved STXs. In the dark at room temperature, STXs undergo a series of slow chemical hydrolysis reactions. The $\mathrm{C}$-toxins lose the $\mathrm{N}$-sulphocarbamoyl group to form dc-GTXs, while the dcGTXs, GTXs and STXs slowly degrade to, as yet unidentified, nontoxic products. The half-lives for the breakdown reactions are in the order of 1-10 weeks, with more than 3 months often being required for greater than $90 \%$ breakdown. A persistence of 1-2 months has been reported for saxitoxin in surface water (Batoreu et al., 2005). In a laboratory study, several STX toxins in the culture medium were stable for long periods also at around $\mathrm{pH} 9-10$ (Castro et al., 2004).

\section{REFERENCES}

Ballot A, Fastner J, Wiedner C (2010). Paralytic shellfish poisoning toxin-producing cyanobacterium Aphanizomenon gracile in Northeast Germany. Appl Environ Microbiol. 76:1173-1180.

Batoreu MCC, Dias E, Pereira P, Franca S (2005). Risk of human exposure to paralytic toxins of algal origin. Environ Toxicol Pharmacol. 19:401-406.

Ben-Gigirey B, Villar-González A (2008). Chemical analysis. In: Botana LM, editors: Seafood and freshwater toxins. Boca Raton (FL): CRC Press: 177-196.

Bowling L, Baker P (1996). Major cyanobacterial bloom in the Barwon-Darling River, Australia, in 1991, and underlying limnological conditions. Mar Freshwater Res. 47:643-657.

Boyer GL (2008). Cyanobacterial toxins in New York and the lower Great Lakes ecosystems. In: Hudnell, HK, editor: Cyanobacterial harmful algal blooms: state of the science and research needs. New York: Springer:153-165. 
Bricelj VM, Cembella AD, Laby D (2014). Temperature effects on kinetics of paralytic shellfish toxin elimination in Atlantic surfclams, Spisula solidissima. Deep Sea Res Part II. Top Stud Oceanogr. 103:308-317.

Carmichael WW, Evans WR, Yin QQ, Bell P, Moczydlowski E (1997). Evidence for paralytic shellfish poisons in the freshwater cyanobacterium Lyngbya wollei (Farlow ex Gomont) comb. nov. Appl Environ Microbiol. 63:3104-3110.

Casero MC, Ballot A, Agha R, Quesada A, Cirés S (2014). Characterization of saxitoxin production and release and phylogeny of sxt genes in paralytic shellfish poisoning toxin-producing Aphanizomenon gracile. Harmful Algae. 37:28-37.

Castro D, Vera D, Lagos N, Garćia C, Vásquez M (2004). The effect of temperature on growth and production of paralytic shellfish poisoning toxins by the cyanobacterium Cylindrospermopsis raciborskii C10. Toxicon. 44:483-489.

Chorus I, editor (2001). Cyanotoxins - occurrence, causes, consequences. Berlin: Springer. $357 \mathrm{pp}$.

Cirés S, Ballot A (2016). A review of the phylogeny, ecology and toxin production of bloom-forming Aphanizomenon spp. and related species within the Nostocales (cyanobacteria). Harmful Algae. 54:21-43.

D’Agostino PM, Song X, Neilan BA, Moffitt MC (2014). Comparative proteomics reveals that a saxitoxin-producing and a nontoxic strain of Anabaena circinalis are two different ecotypes. J Proteome Res. 13:1474-1484.

Dias E, Pereira P, Franca S (2002). Production of paralytic shellfish toxins by Aphanizomenon sp LMECYA 31 (cyanobacteria). J Phycol. 38:705-712.

EFSA (2009). Scientific Opinion: marine biotoxins in shellfish-saxitoxin group. EFSA J. 1019:1-76.

FAO (2004). Marine biotoxins. Food and Agricultural Organization of the United Nations (FAO), Rome. Food and nutrition paper, 80:278 pp. http://www.fao. org/3/y5486e/y5486e00.htm\#Contents.

Fast MD, Cembella AD, Ross NW (2006). In vitro transformation of paralytic shellfish toxins in the clams Mya arenaria and Protothaca staminea. Harmful Algae. 5:79-90.

Ferreira FM, Soler JMF, Fidalgo ML, Fernández-Vila P (2001). PSP toxins from Aphanizomenon flos-aquae (cyanobacteria) collected in the Crestuma-Lever reservoir (Douro river, northern Portugal). Toxicon. 39:757-761.

Foss AJ, Phlips EJ, Aubel MT, Szabo NJ (2012). Investigation of extraction and analysis techniques for Lyngbya wollei derived Paralytic Shellfish Toxins. Toxicon. 60:1148-1158.

Funari E, Testai E (2008). Human health risk assessment related to cyanotoxins exposure. Crit Rev Toxicol. 38:97-125.

García C, Barriga A, Díaz JC, Lagos M, Lagos N (2010). Route of metabolization and detoxication of paralytic shellfish toxins in humans. Toxicon. 55:135-144.

Genenah AA, Shimizu Y (1981). Specific toxicity of paralytic shellfish poisons. J Agric Food Chem. 29:1289-1291.

Hoeger SJ, Hitzfeld BC, Dietrich DR (2005). Occurrence and elimination of cyanobacterial toxins in drinking water treatment plants. Toxicol Appl Pharmacol. 203:231-242.

Humpage A, Rositano J, Bretag A, Brown R, Baker P, Nicholson B et al. (1994). Paralytic shellfish poisons from Australian cyanobacterial blooms. Mar Freshwater Res. 45:761-771. 
Ikawa M, Wegener K, Foxall TL, Sasner JJ (1982). Comparison of the toxins of the blue-green alga Aphanizomenon flos-aquae with the Gonyaulax toxins. Toxicon. 20:747-752.

Jančula D, Straková L, Sadílek J, Maršálek B, Babica P (2014). Survey of cyanobacterial toxins in Czech water reservoirs-the first observation of neurotoxic saxitoxins. Environ Sci Pollut Res. 21:8006-8015.

Kaas H, Henriksen P (2000). Saxitoxins (PSP toxins) in Danish lakes. Water Res. 34:2089-2097.

Kellmann R, Mihali TK, Jeon YJ, Pickford R, Pomati F, Neilan BA (2008). Biosynthetic intermediate analysis and functional homology reveal a saxitoxin gene cluster in cyanobacteria. Appl Environ Microbiol. 74:4044-4053.

Kleinteich J, Wood SA, Puddick J, Schleheck D, Küpper FC, Dietrich D (2013). Potent toxins in Arctic environments-presence of saxitoxins and an unusual microcystin variant in Arctic freshwater ecosystems. Chem-Biol Interact. 206:423-431.

Lagos N, Onodera H, Zagatto PA, Andrinolo D, Azevedo SMFO, Oshima I (1999). The first evidence of paralytic shellfish toxins in the freshwater cyanobacterium Cylindrospermopsis raciborskii, isolated from Brazil. Toxicon. 37:1359-1373.

Lajeunesse A, Segura PA, Gélinas M, Hudon C, Thomas K, Quilliam MA et al. (2012). Detection and confirmation of saxitoxin analogues in freshwater benthic Lyngbya wollei algae collected in the St. Lawrence River (Canada) by liquid chromatography-tandem mass spectrometry. J Chromatogr A. 1219:93-103.

Liu Y, Chen W, Li D, Shen Y, Li G, Liu Y (2006a). First report of aphantoxins in China - waterblooms of toxigenic Aphanizomenon flos-aquae in Lake Dianchi. Ecotoxicol Environ Safety. 65:84-92.

Liu Y, Chen W, Li D, Shen Y, Liu Y, Song L (2006b). Analysis of paralytic shelfish toxins in Aphanizomenon DC-1 from Lake Dianchi, China. Environ Toxicol. 21:289-295.

Llewellyn L, Negri A, Doyle J, Baker P, Beltran E, Neilan B (2001). Radioreceptor assays for sensitive detection and quantitation of saxitoxin and its analogues from strains of the freshwater cyanobacterium, Anabaena circinalis. Environ Sci Technol. 35:1445-1451.

Lopes VM, Baptista M, Repolho T, Rosa R, Costa PR (2014). Uptake, transfer and elimination kinetics of paralytic shellfish toxins in common octopus (Octopus vulgaris). Aquat Toxicol. 146:205-211.

Lopes VM, Lopes AR, Costa P, Rosa R (2013). Cephalopods as vectors of harmful algal bloom toxins in marine food webs. Mar Drugs. 11:3381-3409.

McLaughlin J, Fearey D, Esposito T, Porter K (2011). Paralytic shellfish poisoning: southeast Alaska, May-June 2011. Morbid Mortal Wkly Rep. 60:1554-1556.

Mihali TK, Carmichael WW, Neilan BA (2011). A putative gene cluster from a Lyngbya wollei bloom that encodes paralytic shellfish toxin biosynthesis. PLoS One. 6:e14657.

Mihali TK, Kellmann R, Neilan BA (2009). Characterisation of the paralytic shellfish toxin biosynthesis gene clusters in Anabaena circinalis AWQC131C and Aphanizomenon sp. NH-5. BMC Biochem. 10:8.

Molica R, Onodera H, García C, Rivas M, Andrinolo D, Nascimento S et al. (2002). Toxins in the freshwater cyanobacterium Cylindrospermopsis raciborskii (Cyanophyceae) isolated from Tabocas reservoir in Caruaru, Brazil, including demonstration of a new saxitoxin analogue. Phycologia. 41:606-611. 
Munday R, Thomas K, Gibbs R, Murphy C, Quilliam MA (2013). Acute toxicities of saxitoxin, neosaxitoxin, decarbamoyl saxitoxin and gonyautoxins $1 \& 4$ and $2 \& 3$ to mice by various routes of administration. Toxicon 76:77-83.

Negri AP, Jones GJ (1995). Bioaccumulation of paralytic shellfish poisoning (PSP) toxins from the cyanobacterium Anabaena circinalis by the freshwater mussel Alathyria condola. Toxicon. 33:667-678.

Neilan BA, Pearson LA, Moffitt MC, Mihali K, Kaebernick M, Kellmann R et al. (2008). The genetics and genomics of cyanobacterial toxicity. In: Hudnell, HK, editor: Cyanobacterial harmful algal blooms: state of the science and research needs. New York: Springer:417-452.

Nogueira IC, Pereira P, Dias E, Pflugmacher S, Wiegand C, Franca S et al. (2004). Accumulation of paralytic shellfish toxins (PST) from the cyanobacterium Aphanizomenon issatschenkoi by the cladoceran Daphnia magna. Toxicon. 44:773-780.

Onodera H, Satake M, Oshima Y, Yasumoto T, Carmichael WW (1997). New saxitoxin analogues from the freshwater filamentous cyanobacterium Lyngbya wollei. Nat Toxins. 5:146-151.

Oshima Y (1995a). Chemical and enzymatic transformation of paralytic shellfish toxins in marine organisms. In: Lassus P, Arzul G, Erard E et al., editors: Harmful marine algal blooms. Paris: Lavoisier Intercept:475-480.

Oshima Y (1995b). Postcolumn derivatization liquid chromatographic method for paralytic shellfish toxins. J AOAC Int. 78:528-532.

Oshima Y, Sugino K, Yasumoto T (1989). Latest advances in HPLC analysis of paralytic shellfish toxins. In: Natori S, Hashimoto K, Ueno Y, editors: Mycotoxins and Phycotoxins '88. Amsterdam: Elsevier:319-326.

Pearson L, Mihali T, Moffitt M, Kellmann R, Neilan B (2010). On the chemistry, toxicology and genetics of the cyanobacterial toxins, microcystin, nodularin, saxitoxin and cylindrospermopsin. Mar Drugs. 8:1650-1680.

Pearson LA, Dittmann E, Mazmouz R, Ongley SE, D'Agostino PM, Neilan BA (2016). The genetics, biosynthesis and regulation of toxic specialized metabolites of cyanobacteria. Harmful Algae. 54:98-111.

Pereira P, Dias E, Franca S, Pereira E, Carolino M, Vasconcelos V (2004). Accumulation and depuration of cyanobacterial paralytic shellfish toxins by the freshwater mussel Anodonta cygnea. Aquat Toxicol. 68:339-350.

Pereira P, Onodera H, Andrinolo D, Franca S, Araujo F, Lagos N et al. (2000). Paralytic shellfish toxins in the freshwater cyanobacterium Aphanizomenon flos-aquae, isolated from Montargil reservoir, Portugal. Toxicon. 38:1689-1702.

Pomati F, Sacchi S, Rossetti C, Giovannardi S, Onodera H, Oshima Y et al. (2000). The freshwater cyanobacterium Planktothrix sp. FP1: molecular identification and detection of paralytic shellfish poisoning toxins. J Phycol. 36:553-562.

Rapala J, Robertson A, Negri AP, Berg KA, Tuomi P, Lyra C et al. (2005). First report of saxitoxin in finnish lakes and possible associated effects on human health. Environ Toxicol. 20:331-340.

Robertson A, Stirling D, Robillot C, Llewellyn L, Negri A (2004). First report of saxitoxin in octopi. Toxicon. 44:765-771.

Sasner JJ, Ikawa M, Foxall TL (1984). Studies on Aphanizomenon and Microcystis toxins. In: Ragelis E, editor: Seafood Toxins. Washington (DC): ACS Publications: 391-406. 
Silva CSP, Genuário DB, Vaz MGMV, Fiore MF (2014). Phylogeny of culturable cyanobacteria from Brazilian mangroves. Syst Appl Microbiol. 37:100-112.

Sivonen K, Jones GJ (1999). Cyanobacterial toxins. In: Chorus I, Bartram J, editors: Toxic cyanobacteria in water. London: E \& FN Spoon:41-111.

Smith FM, Wood SA, van Ginkel R, Broady PA, Gaw S (2011). First report of saxitoxin production by a species of the freshwater benthic cyanobacterium, Scytonema Agardh. Toxicon. 57:566-573.

Stüken A, Orr RJ, Kellmann R, Murray SA, Neilan BA, Jakobsen KS (2011). Discovery of nuclear-encoded genes for the neurotoxin saxitoxin in dinoflagellates. PLoS One. 6:e20096.

Testai E, Scardala S, Vichi S, Buratti FM, Funari E (2016). Risk to human health associated with the environmental occurrence of cyanobacterial neurotoxic alkaloids anatoxins and saxitoxins. Crit Rev Toxicol. 46:385-419.

Trainer VL, Hardy FJ (2015). Integrative monitoring of marine and freshwater harmful algae in Washington State for public health protection. Toxins. 7:1206-1234.

Velzeboer RM, Baker PD, Rositano J, Heresztyn T, Codd GA, Raggett SL (2000). Geographical patterns of occurrence and composition of saxitoxins in the cyanobacterial genus Anabaena (Nostocales, Cyanophyta) in Australia. Phycologia. 39:395-407.

WHO (2003). Guidelines for safe recreational water environments. Vol. 1: Coastal and fresh waters. Geneva: World Health Organization. https://apps.who.int/ iris/handle/10665/42591

WHO (2020). Cyanobacterial toxins: Saxitoxins. Background document for development of WHO Guidelines for Drinking-water Quality and Guidelines for Safe Recreational Water Environments. Geneva: World Health Organization. https://apps.who.int/iris/handle/10665/338069

Wichmann CF, Niemczura WP, Schnoes HK, Hall S, Reichardt PB, Darling SD (1981). Structures of two novel toxins from Protogonyaulax. J Am Chem Soc. 103:6977-6978.

Wiese M, D’agostino PM, Mihali TK, Moffitt MC, Neilan BA (2010). Neurotoxic alkaloids: saxitoxin and its analogs. Mar Drugs. 8:2185-2211.

Wörmer L, Cirés S, Agha R, Verdugo M, de Hoyos C, Quesada A (2011). First detection of cyanobacterial PSP (paralytic shellfish poisoning) toxins in Spanish freshwaters. Toxicon. 57:918-921. 


\subsection{ANATOXIN-A(S)}

\section{Emanuela Testai}

Anatoxin-a(S) $(\operatorname{ATX}(S))$ is, despite the similarity of the names, not structurally related to anatoxin-a: while the latter is an alkaloid, $\operatorname{ATX}(S)$ is an organophosphate (see below). It received its name during initial studies which isolated multiple toxic fractions from a strain of Anabaena sp. to which letters or suffixes were assigned. The " $S$ " in the name denotes a characteristic symptom of exposure in mammals: "salivation". Because of its totally different chemical structure and mechanism of action, Fiore et al. (2020) proposed renaming it to guanitoxin, advocating that the new name should reflect its chemical composition.

\subsection{Chemical structure}

Anatoxin-a(S) is an N-hydroxyguanidine methyl phosphate ester with a molecular weight of $252 \mathrm{Da}$. It is the only known natural organophosphonate besides biomolecules such as DNA, RNA and ATP (Figure 2.5; Mahmood \& Carmichael, 1987). No structural variants of ATX(S) have been detected so far.

Anatoxin-a(S) decomposes rapidly in basic solutions but is relatively stable in neutral and acidic conditions (Matsunaga et al., 1989). It is inactivated at temperatures higher than $40{ }^{\circ} \mathrm{C}$ (Carmichael, 2001).

\subsubsection{Toxicity: mode of action}

Anatoxin-a(S) irreversibly inhibits acetylcholinesterase (AChE) in the neuromuscular junctions (but not in the central nervous system) blocking hydrolysis of the neurotransmitter. This results in acetylcholine accumulation, leading to nerve hyperexcitability. The acute neurological effects in mammals are muscle weakness, respiratory distress (dyspnoea) and convulsions preceding death, which occurs due to respiratory arrest (i.p. $\mathrm{LD}_{50}$ in mice $=40-228 \mu \mathrm{g} / \mathrm{kg}$ bw,

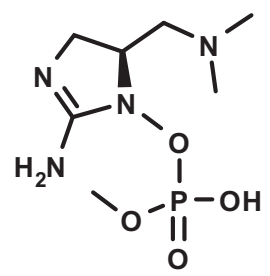

Figure 2.5 Chemical structure of anatoxins-a(S). Molecular mass (monoisotopic): 252.099 Da; molecular weight (average): $252.212 \mathrm{~g} / \mathrm{mol}$. 
lower in rats i.p. $\mathrm{LD}_{50}=5.3 \mathrm{mg} / \mathrm{kg}$ bw). Viscous mucoid hypersalivation is a typical symptom induced by ATX(S).

Data on oral administration as well as on subchronic and/or chronic toxicity are not available.

\subsubsection{Derivation of guideline values for anatoxin-a(S) in water}

No toxicological data are available for deriving an acute dose NOAEL or LOAEL as point of departure, and data on subchronic and chronic exposure are also lacking. Therefore, no TDI or guideline value can yet be derived for $\operatorname{ATX}(S)$.

New Zealand has established a limit as provisional maximum acceptable value of $1 \mu \mathrm{g} / \mathrm{L}$ for total ATX(S) content in drinking-water (Chorus, 2012).

\subsubsection{Production, occurrence and environmental fate}

Anatoxin-a(S) has been reported from strains of Dolichospermum (Anabaena) flosaquae from Canada (Carmichael \& Gorham, 1978), in both field samples and strains of D. lemmermannii from Denmark (Henriksen et al., 1997) and from Portugal (Fristachi \& Sinclair, 2008), in D. flosaquae from the USA and Scotland (Matsunaga et al., 1989; Codd, 1995), in D. spiroides from Brazil (Monserrat et al., 2001), and in D. crassa from southern Brazil (Becker et al., 2010).

The available literature on $\operatorname{ATX}(S)$ biosynthesis is scant, and the gene cluster responsible for the biosynthesis of ATX(S) has not yet been identified (Pearson et al., 2016). Only the synthesis of the cyclic moiety of ATX(S) has been reported (Matsunaga et al., 1989; Moura \& Pinto, 2010).

The precursor for the guanidine group has been proposed to be $L$-arginine, which is hydroxylated at C4, as demonstrated by feeding studies (Moore et al., 1992) with radiolabelled arginine and (4S)-4-hydroxy-arginine, but none of the further steps have been described to date.

The presence of $\operatorname{ATX}(S)$ in waterbodies is sparsely documented (Table 2.7); one of the reasons could be related to analytical difficulties such as the absence of analytical standards, and the possible co-occurrence of organophosphate pesticides in the environment, limiting the use of biological tests, including biosensors, based on AChE inhibition (Devic et al., 2002). Indeed, mouse bioassays and acetylcholine esterase inhibition assays may be used to infer $\operatorname{ATX}(S)$ levels in environmental samples; however, these tests are not specific (Patocka et al., 2011). This sometimes leads only to a qualitative description of detection, without quantification (Molica et al., 2005). The only chance to use analytical methodologies, overcoming the 
lack of standards to identify the presence of the toxin, is the LC-MS/MS fragmentation pattern for $\mathrm{ATX}(\mathrm{S})$ in cyanobacterial cultures.

Highly variable $\operatorname{ATX}(S)$ contents were detected in three Danish lakes dominated by D. lemmermannii, reaching maximum contents of $3300 \mu \mathrm{g} / \mathrm{g}$ dw (Henriksen et al., 1997).

The presence of ATX $(S)$ was also suggested by results from acetylcholine esterase inhibition assay in cyanobacterial crusts in Qatar (Metcalf et al., 2012).

Data on chemical breakdown in the natural water environment and biodegradation of this cyanotoxin are not available.

\section{REFERENCES}

Becker V, Ihara P, Yunes JS, Huszar VLM (2010). Occurrence of anatoxin-a(S) during a bloom of Anabaena crassa in a water-supply reservoir in southern Brazil. J Appl Phycol. 22:235-241.

Carmichael WW (2001). Health effects of toxin-producing cyanobacteria: "The CyanoHABs". Human Ecol Risk Assess. 7:1393-1407.

Carmichael WW, Gorham PR (1978). Anatoxins from clones of Anabaena flos-aquae isolated from lakes of western Canada: With 3 figures and 2 tables in the text. Mitt Int Verein Limnol. 21:285-295.

Chorus I (2012). Current approaches to cyanotoxin risk assessment, risk management and regulations in different countries. Dessau: Federal Environment Agency.

Codd G (1995). The toxicity of benthic blue-green algae in Scottish freshwaters. The Scottish Office, Foundation for Water Research, Marlow.

Devic E, Li DH, Dauta A, Henriksen P, Codd GA, Marty JL et al. (2002). Detection of anatoxin-a(s) in environmental samples of cyanobacteria by using a biosensor with engineered acetylcholinesterases. Appl Environ Microbiol. 68:4102-4106.

Fiore MF, de Lima ST, Carmichael WW, McKinnie SM, Chekan JR, Moore BS (2020). Guanitoxin, re-naming a cyanobacterial organophosphate toxin. Harmful Algae. 92:101737.

Fristachi A, Sinclair JL (2008). Occurrence of cyanobacterial harmful algal blooms workgroup report. In: Hudnell HK, editors: Cyanobacterial harmful algal blooms: state of the science and research needs. New York: Springer:45-103.

Henriksen P, Carmichael WW, An JS, Moestrup O (1997). Detection of an anatoxin$\mathrm{a}(\mathrm{s})$-like anticholinesterase in natural blooms and cultures of Cyanobacteria/ blue-green algae from Danish lakes and in the stomach contents of poisoned birds. Toxicon. 35:901-913.

Mahmood NA, Carmichael WW (1987). Anatoxin-a (s), an anticholinesterase from the cyanobacterium Anabaena flos-aquae NRC-525-17. Toxicon. 25:1221-1227.

Matsunaga S, Moore RE, Niemczura WP, Carmichael WW (1989). Anatoxin-a (s), a potent anticholinesterase from Anabaena flos-aquae. J Am Chem Soc. 111:8021-8023.

Metcalf JS, Richer R, Cox PA, Codd GA (2012). Cyanotoxins in desert environments may present a risk to human health. Sci Tot Environ. 421:118-123. 
Molica RJ, Oliveira EJ, Carvalho PV, Costa AN, Cunha MC, Melo GL et al. (2005). Occurrence of saxitoxins and an anatoxin-a (s)-like anticholinesterase in a Brazilian drinking water supply. Harmful Algae. 4:743-753.

Monserrat JM, Yunes JS, Bianchini A (2001). Effects of Anabaena spiroides (cyanobacteria) aqueous extracts on the acetylcholinesterase activity of aquatic species. Environ Toxicol Chem. 20:1228-1235.

Moore BS, Ohtani I, Moore RE, Carmichael WW (1992). Biosynthesis of anatoxin-a (s): origin of the carbons. Tetrahedron Lett. 33:6595-6598.

Moura S, Pinto E (2010). Synthesis of cyclic guanidine intermediates of anatoxin-a (s) in both racemic and enantiomerically pure forms. Synlett. 2010:967-969.

Patocka J, Gupta RC, Kuca K (2011). Anatoxin-a (s): natural organophosphorus anticholinesterase agent. Mil Med Sci Lett 80:129-139.

Pearson LA, Dittmann E, Mazmouz R, Ongley SE, D’Agostino PM, Neilan BA (2016). The genetics, biosynthesis and regulation of toxic specialized metabolites of cyanobacteria. Harmful Algae. 54:98-111. 


\subsection{MARINE DERMATOTOXINS}

\section{Nicholas J. Osborne}

The dermatotoxic reaction to the marine cyanobacterium "Lyngbya majuscula" has been associated with cases of dermatitis in humans, reported since the 1950s (Grauer \& Arnold, 1961). This spurred intensive research on natural products revealing hundreds of secondary metabolites supposedly produced by this species (Gerwick et al., 2008). This enormous metabolic diversity was questioned by Engene et al. (2011) who suggest that what has been viewed as a single species or species complex based on morphological criteria in fact represents a multitude of genera and species on the basis of molecular analyses (Engene et al., 2010).

The traditional genus Lyngbya consists of several hundred described species (see Chapter 3) of marine and freshwater cyanobacteria with global distribution. It is now proposed that tropical Lyngbya-like cyanobacteria are separated from other members of the genus Lyngbya, as they have been found to be genetically distinct. The new genus Moorea, in particular M. producens, largely appears to be synonymous to "L. majuscula" (Engene et al., 2012) but other names have been used as synonyms, for example, Microcoleus lyngbyaceus (Sims \& Zandee van Rilland, 1981). Further genera amended from Lyngbya are Dapis (Engene et al., 2018) and Okeania (Engene et al., 2013b) - and more may follow. However, since it is not possible to retrospectively evaluate the taxonomic assignment of samples in original publications, this chapter gives "L. majuscula" in quotation marks whenever the possibility exists that the taxonomic assignment would be different today. Temperate species of "L. majuscula" have been recorded, but essentially nothing is known of their toxicity (Hällfors, 2004).

" $L$. majuscula" is a benthic cyanobacterium appearing as clumps of a matted mass of filaments $10-30 \mathrm{~cm}$ long, sometimes referred to as "mermaids' hair", that grows to depths of up to $30 \mathrm{~m}$, predominantly in the tropics and subtropics (Izumi \& Moore, 1987). Elevated concentrations of iron, nitrogen and phosphorus have been proposed to be drivers of mass development or blooming of this cyanobacterium (Albert et al., 2005).

Among some 200 natural products that have been linked to tropical "L. majuscula" (Liu \& Rein, 2010; Engene et al., 2013a), some have been found to induce irritant contact dermatitis, that is, to be dermatotoxins: aplysiatoxin (AT; Kato \& Scheuer, 1974), (Mitchell et al., 2000), debromoaplysiatoxin (DAT; Mynderse et al., 1977) and lyngbyatoxin A (LTA; Cardellina et al., 1979). Other natural products produced by this cyanobacterium include malyngamides, apratoxins and dolostatins (Todd \& Gerwick, 1995; Mitchell et al., 2000; Luesch et al., 2001). 


\subsection{Chemical structures}

Lyngbyatoxin A's structure (Figure 2.6) was initially determined in 1979 using samples collected at Kahala Beach, Oahu, Hawaii (Cardellina et al., 1979). An isomer of teleocidin A, first extracted from the actinomycete Streptomyces medicocidcus, was found to have an identical structure to LTA (Fujiki et al., 1981), with this organism producing both the $19 \mathrm{R}$ and $19 S$ epimers (i.e., the same chemical formula but different three-dimensional orientations), while in " $L$. majuscula" only the $19 R$ epimer was found. Lyngbyatoxin B and lyngbyatoxin C, compounds with similar chemical structure, were extracted from Hawaiian specimens of "L. majuscula" (Aimi et al., 1990), as was 12-epi-lyngbyatoxin A and further congeners (Jiang et al., 2014a; Jiang et al., 2014b). Lyngbyatoxin A is more lipophilic than the other lyngbyatoxin, with a mean $\log n$-octanol/water partition coefficient of 1.53 (Stafford et al., 1992).

Debromoaplysiatoxin was first isolated in 1977 and the structure derived from extracts of both Lyngbya gracilis (reclassified to Leibleinia gracilis; see also below) and an inseparable consortium of Phormidium (Oscillatoria) nigroviridis and Schizothrix calcicola (Mynderse et al., 1977). The phenolic bis-lactones AT and DAT have similar structures apart from the bromine molecule on the benzene ring (Figure 2.6).

(a)<smiles>C=C[C@](C)(CC)c1ccc(N(C)[C@@H](C(=O)N[C@H](CC)CO)C(C)C)c2c1CNC2</smiles>

(b)

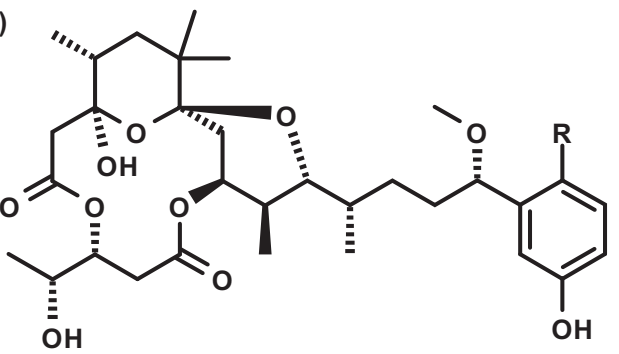

Figure 2.6 Structures of (a) lyngbyatoxin A (molecular mass (monoisotopic): $437.304 \mathrm{Da}$; molecular weight (average): $437.63 \mathrm{I} \mathrm{g} / \mathrm{mol})$, (b) debromoaplysiatoxin $(\mathrm{R}=\mathrm{H}$; $M M(m o n o): 592.325 \mathrm{Da} ; \mathrm{MW}(\mathrm{ave}): 592.73 \mathrm{~g} / \mathrm{mol})$ and aplysiatoxin $(\mathrm{R}=\mathrm{Br}$; MM(mono): $672.235 \mathrm{Da}$; MW (ave): $671.63 \mathrm{~g} / \mathrm{mol}$ ). 


\subsubsection{Toxicity}

Although toxicity was first observed in Hawaii in 1912 (Banner, 1959; Osborne et al., 2008), the first confirmed activity by "L. majuscula" that caused acute dermatitis was not determined until 1958, via patch testing in humans (Grauer \& Arnold, 1961). Banner revealed that the dermatitis was irritant rather than allergenic, and this has been replicated in a later study (Banner, 1959; Osborne et al., 2008): histology of mouse and human skin exposed to either crude extracts of " $L$. majuscula" or its purified toxins showed acute vesicular dermatitis consistent with irritant contact dermatitis after topical application. Microscopic examination described peeling skin and oedema of the epidermis. The dermis was infiltrated with a range of inflammatory cells, including mononuclear cells, neutrophils and eosinophils (Grauer \& Arnold, 1961; Osborne et al., 2008). Vesicles contained polymorphonuclear leukocytes and red blood cells, with deep infiltration of the epidermis with polymorphonuclear leukocytes (Grauer \& Arnold, 1961). Ito et al. (2002) found LTA to have a minimum lethal dose $\left(\mathrm{LD}_{100}\right)$ of $0.30 \mathrm{mg} / \mathrm{kg}$ (intraperitoneal) in mice.

Applied cutaneously, LTA had an median effective dose $\mathrm{ED}_{50}$ (dose causing a biological response in $50 \%$ of the sample) with a lower index (reddening) of $\sim 4.8 \mathrm{ng} / \mathrm{kg}$ in mice tested via topical application, with DAT and AT showing slightly lower activity (Fujiki et al., 1983). LTA has shown skin penetration rates of $23 \%$ and $6.2 \%$ for guinea pig and human skin, respectively, within $1 \mathrm{~h}$ (Stafford et al., 1992). However, not all of the toxicity in "L. majuscula" specimens producing LTA is explained by the concentrations of LTA present, and other factors present thus must be affecting toxicity (Osborne et al., 2008).

Furthermore, animals that feed on toxic "Lyngbya" or Moorea appear to bioaccumulate toxin: the first report dates back to classical times by Pliny (Plinius, 23-79 AD) who reported toxicity of marine gastropods - the sea hare. Kato and Scheuer (1974) first isolated AT and DAT from their digestive tract. Sea hare (e.g., Aplysia californica; Gribble, 1999; Stylocheilus striatus; Capper et al., 2006) appear to preferentially feed on cyanobacteria, including "L. majuscula" (and possibly other marine cyanobacteria) and to sequester their toxins (Pennings et al., 1996). This bioaccumulation potentially also occurs in other grazers (Capper et al., 2005). Accidental skin contact with chemicals extracted from sea hares led to dermal irritation. While some invertebrate grazers appear to be indifferent to extracts of the cyanobacteria "L. majuscula", reef fish are more likely to be deterred (Capper et al., 2006).

For AT, Ito and Nagai (1998) report that dosing of mice at 500, 1000 or $3000 \mu \mathrm{g} / \mathrm{kg}$ intraperitoneally resulted in bleeding in the small intestine, blood loss and pale liver, loss of cells from the stomach, exposure of the lamina propria lumen with small intestine capillaries congested and all 
villi showing erosion and bleeding. Dosing orally at $0.8 \mu \mathrm{g} / \mathrm{kg}$, AT induced increased permeability of gastrointestinal vascularisation as well as local inflammation and necrosis. The consequences of the latter were intraperitoneal haemorrhage, hypovolemic liver, small intestinal sloughing and haemorrhage. The activity of AT was proposed to be due to its effect on protein kinase C, not peritonitis (Ito \& Nagai, 1998). At an oral or intraperitoneal dose of AT at which $50 \%$ of animals were affected, symptoms resembled those of LTA poisoning (Ito et al., 2002).

For DAT, dermal toxicity has also been shown (Solomon \& Stoughton, 1978; Osborne et al., 2008). For ear reddening, DAT and AT show highly lower activity than LTA (see above and Fujiki et al., 1983). DAT was originally reported as isolated from Leibleinia (Lyngbya) gracilis, a species classified today in the order Synechococcales. However, a footnote in the publication notes that one taxonomist identified the organism as "L. majuscula" (Mynderse et al., 1977). Other authors have suggested that these toxins are also present in seaweed species: in papers reporting chemicals extracted from the red alga Gracilaria coronopifolia, the authors suggested the toxicity of the seaweed may be due to epiphytically growing cyanobacteria (Nagai et al., 1996; Nagai et al., 1997). It is still unclear if this is the case, but it is entirely possible as the epiphytic growth of "L. majuscula" and other cyanobacteria on seaweeds has been reported worldwide (Moore, 1982; Fletcher, 1995).

Both LTA and DAT have been shown to have tumour-promoting activities via the protein kinase C activation pathway (Nakamura et al., 1989).

In spite of $\mathrm{EC}_{50}$ or $\mathrm{LD}_{50}$ values given for some of the marine dermatotoxins, no guideline values for their concentration in water used for recreation can be given because, in contrast to the cyanotoxins discussed in sections 2.1-2.5, their exposure pathway is not through ingestion, but through dermal contact, and this is not accessible to quantification for filamentous macroalgae forming mats and rafts.

\subsubsection{Incidents of human injury through marine cyanobacterial dermatotoxins}

Hawaii 1950-1983

In late 1950s, "L. majuscula" was first purported as the agent responsible for an epidemic of acute dermatitis in Hawaii. 125 people were reported suffering dermatitis after swimming at beaches in north-east Oahu, Hawaii, in July and August 1958. After exposure to "L. majuscula", swimmers described symptoms similar to a burn, usually appearing underneath swimming costumes in the genital, perianal and perineum areas. Debate continues if the cause of symptoms chiefly at these locations is the thinner epidermis in these areas or extended exposure with cyanobacterium filaments trapped in clothing. Symptoms within a few hours of exposures included erythema and 
burning followed by deep skin peeling and blistering, which continued for 24-48 h (Grauer \& Arnold, 1961).

In 1976, samples of blooming "L. majuscula" were found to contain DAT. In 1980 in Oahu, 35 people were affected and developed dermatitis 2-20 h after exposure and with symptoms lasting from 2 to 12 days (Serdula et al., 1982). Both AT and DT were found in samples of "L. majuscula" recovered from the ocean (Moore et al., 1984).

In 1983, eye and breathing symptoms were noted in Maui (Anderson et al., 1988). Aerosolised Lyngbya fragments were discovered on sampling with high-volume air filters and from waterfront area windows.

\section{Okinawa 1968 and 1973}

At Gushikawa Beach, Okinawa, in 1968, 242 of 274 bathers developed a rapid-onset dermatitis. Reported symptoms included rash, itching, burning, blisters and deep peeling of the skin. Sensitive outer areas such the genitals, lips and eyes were usually affected. A later bloom of "L. majuscula" was sampled in the same area in September 1973: it caused rashes and blistering in humans and mice (Hashimoto et al., 1976). The compounds extracted and partially characterised had chemical properties similar to those of the uncharacterised toxin found by Moikeha and Chu (1971), and samples collected in the same later were shown to contain DAT and AT (Fujiki et al., 1985).

\section{Queensland, Australia, 1999-2003}

A cross-sectional epidemiological survey of residents of Bribie Island, Australia, was undertaken after some evidence of blooms of "L. majuscula" in the area. Residents exposed to seawater exhibited symptoms associated with exposure to " $L$. majuscula" $(0.6 \%$ of the sample population), including redness in the inguinal region, severe itching and blistering (Osborne et al., 2007). The greater surface area of female swimming costumes may explain their increased prevalence of symptoms as compared to men, with an increased entrapment of cyanobacterial strands. Similar epidemiological observations have been reported from nearby Fraser Island (Osborne \& Shaw, 2008).

Mortality in humans after the consumption of Lyngbya has been reported three times (Sims \& Zandee van Rilland, 1981; Marshall \& Vogt, 1998; Yasumoto, 1998). "L. majuscula" growing epiphytically on the edible endemic Hawaiian alga Gracilaria coronopifolia have also been implicated in poisoning from ingestion of the red alga in 1994 (Nagai et al., 1996; Ito \& Nagai, 2000). Consumption of "L. majuscula" (associated with consuming seaweed) has been associated with an excruciating burning sensation on the patient's lips, anterior part of the oral cavity and the anterior portion of the tongue. Twenty-four hours after consumption, the mucous membranes appeared scalded, swollen and exhibited hyperaemia with several 
erosive lesions. The patient became free of discomfort after 3 days (Sims $\&$ Zandee van Rilland, 1981). It has been postulated that the high incidence of cancers of the digestive system among indigenous Hawaiians may be due to the consumption of seaweed tainted with "L. majuscula" (Moore, 1984). Furthermore, an outbreak of respiratory, eye and skin irritations in Mayotte, an island in the Indian Ocean, in 2010 was linked to exposure to cyanobacteria washed on the beach (Lernout et al., 2011).

\subsubsection{Biosynthesis and occurrence in the environment}

Elements of the biosynthesis of LTA, as well as the genes involved, are reported by Tønder et al. (2004), Read and Walsh (2007), and Edwards and Gerwick (2004). The core of the molecule is synthesised by a nonribosomal peptide synthetase followed by reduction and prenylation steps (Read \& Walsh, 2007). Total synthesis of AT and DAT was achieved by Park et al. (1987). Videau et al. (2016) achieved a heterologous expression of LTA in a strain of Anabaena sp. (PCC 7120).

"L. majuscula" is mainly seen in the tropics and subtropics but has a worldwide distribution (Table 2.9). Different toxicities of samples of this species from around the Hawaii (Grauer \& Arnold, 1961) and the Marshall Islands have been noted, where samples taken on the seaward side of the lagoon were more toxic (Mynderse et al., 1977). Similarly, spatial differences in toxins in Moreton Bay, Australia, have been recorded, with DT being produced on the Western side exclusively, and LTA mainly

Table 2.9 Dermatotoxin contents reported for "L. majuscula" in $\mu g / g$ dry weight, collected on various locations around world

\begin{tabular}{|c|c|c|c|c|}
\hline Location & LTA & DAT & AT & Reference \\
\hline Ryukyus Islands, Okinawa & 240 & & & Hashimoto et al. (1976) \\
\hline $\begin{array}{l}\text { Enewetak Atoll, Marshall } \\
\text { Islands }\end{array}$ & & 133 & & Mynderse et al. (1977) b \\
\hline Kahala Beach, Hawaii & 200 & & & Cardellina et al. (1979) \\
\hline Oahu, Hawaii & & 324 & 81 & Serdula et al. (1982) \\
\hline Moreton Bay,Australia & n.d.-|3| & n.d. -43 & & Osborne (2004) \\
\hline Maui, Hawaii & $10-276$ & n.d. -0.8 & & Osborne (2004) \\
\hline King's Bay, Florida, USA & & n.d. -6.31 & & Harr et al. (2008) \\
\hline Moreton Bay,Australia & n.d. -39 & n.d. -0.3 & & Arthur et al. (2008) \\
\hline Big Island, Hawaii & n.d. -168 & n.d. -540 & & Arthur et al. (2008) \\
\hline
\end{tabular}

n.d.: not detectable. LTA: lyngbyatoxin A; DTA: debromoaplysiatoxin;AT: aplysiatoxin.

a probably LTA, not confirmed.

b producing organism reported as Lyngbya (Leibleinia) gracilis, but probably was “L. majuscula”. 
being produced on the Eastern ocean side, only $30 \mathrm{~km}$ away (Osborne et al., 2002; Osborne, 2004).

Treating DAT and AT with even very mild acid readily leads to dehydration, and the degradation products (anhydrotoxins) do not show the toxicity seen with DAT and AT (Moore, 1984). Hashimoto (1979) reported half of the toxicity of " $L$. majuscula" was lost after $3 \mathrm{~h}$ of exposure to ultraviolet radiation, as did Moikeha and Chu (1971). The absence of toxins was noted in seawater surrounding a large bloom of toxic L. majuscula in Australia (Osborne, 2004). It appears that the toxins are biodegradable in the environment, but further work is required to explore this.

\section{REFERENCES}

Aimi N, Odaka H, Sakai S, Fujiki H, Suganuma M, Moore RE et al. (1990). Lyngbyatoxins B and C, two new irritants from Lyngbya majuscula. J Nat Prod. 53:1593-1596.

Albert S, O‘Neil JM, Udy JW, Ahern KS, O‘Sullivan CM, Dennison WC (2005). Blooms of the cyanobacterium Lyngbya majuscula in coastal Queensland, Australia: disparate sites, common factors. Mar Pollut Bull. 51:428-437.

Anderson B, Sims J, Liang A, Minette H (1988). Outbreak of eye and respiratory irritation in Lahaina, Maui, possibly associated with Microcoleus lyngbyaceus. J Environ Health. 50:205-209.

Arthur K, Limpus C, Balazs G, Capper A, Udy J, Shaw G et al. (2008). The exposure of green turtles (Chelonia mydas) to tumour promoting compounds produced by the cyanobacterium Lyngbya majuscula and their potential role in the aetiology of fibropapillomatosis. Harmful Algae. 7:114-125.

Banner AH (1959). A dermatitis-producing algae in Hawaii. Hawaii Med J. 19:35-36. Capper A, Tibbetts IR, O'Neil JM, Shaw GR (2006). Feeding preference and deterrence in rabbitfish Siganus fuscescens for the cyanobacterium Lyngbya majuscula in Moreton Bay, south-east Queensland, Australia. J Fish Biol. 68:1589-1609.

Capper A, Tibbetts IR, O'Neil YM, Shaw GR (2005). The fate of Lyngbya majuscula toxins in three potential consumers. J Chem Ecol. 31:1595-1606.

Cardellina JHd, Marner FJ, Moore RE (1979). Seaweed dermatitis: structure of lyngbyatoxin A. Science. 204:193-195.

Edwards DJ, Gerwick WH (2004). Lyngbyatoxin biosynthesis: sequence of biosynthetic gene cluster and identification of a novel aromatic prenyltransferase. J Am Chem Soc. 126:11432-11433.

Engene N, Choi H, Esquenazi E, Rottacker EC, Ellisman MH, Dorrestein PC et al. (2011). Underestimated biodiversity as a major explanation for the perceived rich secondary metabolite capacity of the cyanobacterial genus Lyngbya. Environ Microbiol. 13:1601-1610.

Engene N, Coates RC, Gerwick WH (2010). 16S rRNA Gene heterogeneity in the filamentous marine cyanobacterial genus Lyngbya. J Phycol. 46:591-601. 
Engene N, Gunasekera SP, Gerwick WH, Paul VJ (2013a). Phylogenetic Inferences reveal a large extent of novel biodiversity in chemically rich tropical marine cyanobacteria. Appl Environ Microbiol. 79:1882-1888.

Engene N, Paul VJ, Byrum T, Gerwick WH, Thor A, Ellisman MH (2013b). Five chemically rich species of tropical marine cyanobacteria of the genus Okeania gen. nov.(Oscillatoriales, Cyanoprokaryota). J Phycol. 49:1095-1106.

Engene N, Rottacker EC, Kaštovský J, Byrum T, Choi H, Ellisman MH et al. (2012). Moorea producens gen. nov., sp. nov. and Moorea bouillonii comb. nov., tropical marine cyanobacteria rich in bioactive secondary metabolites. Int J Syst Evol Microbiol. 62:1171-1178.

Engene N, Tronholm A, Paul VJ (2018). Uncovering cryptic diversity of Lyngbya: the new tropical marine cyanobacterial genus Dapis (Oscillatoriales). J Phycol. 54:435-446.

Fletcher R (1995). Epiphytism and fouling in Gracilaria cultivation: an overview. J Appl Phycol. 7:325-333.

Fujiki H, Ikegami K, Hakii H, Suganuma M, Yamaizumi Z, Yamazato K et al. (1985). A blue-green alga from Okinawa contains aplysiatoxins, the third class of tumor promoters. Jpn J Cancer Res. 76:257-259.

Fujiki H, Mori M, Nakayasu M, Terada M, Sugimura T, Moore RE (1981). Indole alkaloids: dihydroteleocidin B, teleocidin, and lyngbyatoxin A as members of a new class of tumor promoters. Proc Natl Acad Sci USA. 78:3872-3876.

Fujiki H, Suganuma M, Tahira T, Yoshioka A, Nakayasu M, Endo Y et al. (1983). Nakahara memorial lecture. New classes of tumor promoters: teleocidin, aplysiatoxin, and palytoxin. Princess Takamatsu Symp. 14:37-45.

Gerwick WH, Coates RC, Engene N, Gerwick L, Grindberg RV, Jones AC et al. (2008). Giant marine cyanobacteria produce exciting potential pharmaceuticals. Microbe. 3:277.

Grauer FH, Arnold HL (1961). Seaweed dermatitis: first report of dermatitis-producing marine algae. Arch Dermatol. 84:720-732.

Gribble GW (1999). The diversity of naturally occurring organobromine compounds. Chem Soc Rev. 28:335-346.

Hällfors G (2004). Checklist of Baltic Sea phytoplankton species. Helsinki: Helsinki Commission Baltic Marine Environment Protection Commission.

Harr KE, Szabo NJ, Cichra M, Phlips EJ (2008). Debromoaplysiatoxin in Lyngbyadominated mats on manatees (Trichechus manatus latirostris) in the Florida King's Bay ecosystem. Toxicon. 52:385-388.

Hashimoto Y (1979). Marine toxins and other bioactive marine metabolites. Tokyo: Japan Scientific Societies Press:369 pp.

Hashimoto Y, Kamiya H, Yamazato K, Nozawa K (1976). Occurrence of a toxic bluegreen alga inducing skin dermatitis in Okinawa. In: Ohsaka A, Hayashi K, Sawai Y, editors: Animal, plant, and microbial toxins. New York: Plenum:333-338.

Ito E, Nagai H (1998). Morphological observations of diarrhea in mice caused by aplysiatoxin, the causative agent of the red alga Gracilaria coronopifolia poisoning in Hawaii. Toxicon. 36:1913-1920.

Ito E, Nagai H (2000). Bleeding from the small intestine caused by aplysiatoxin, the causative agent of the red algae Gracilaria coronopifolia poisoning in Hawaii. Toxicon. 38:123-132.

Ito E, Satake M, Yasumoto T (2002). Pathological effects of lyngbyatoxin A upon mice. Toxicon. 40:551-556. 
Izumi AK, Moore RE (1987). Seaweed (Lyngbya majuscula) dermatitis. Clin Dermatol. 5:92-100.

Jiang W, Tan S, Hanaki Y, Irie K, Uchida H, Watanabe R et al. (2014a). Two new lyngbyatoxin derivatives from the cyanobacterium, Moorea producens. Mar Drugs. 12:5788-5800.

Jiang WN, Zhou W, Uchida H, Kikumori M, Irie K, Watanabe R et al. (2014b). A new lyngbyatoxin from the Hawaiian cyanobacterium Moorea producens. Mar Drugs. 12:2748-2759.

Kato Y, Scheuer PJ (1974). Aplysiatoxin and debromoaplysiatoxin, constituents of the marine mollusk Stylocheilus longicauda (Quoy and Gaimard, 1824). J Am Chem Soc. 96:2245-2246.

Lernout T, Thiria J, Maltaverne E, Salim M, Turquet J, Lajoindre G et al. (2011). Alerte aux cynanobactéries sur la plage de N'Gouja, Mayotte, avril 2010. Bulletin de veille sanitaire. 9:12-14.

Liu L, Rein KS (2010). New peptides isolated from Lyngbya species: a review. Marine Drugs. 8:1817-1837.

Luesch H, Yoshida WY, Moore RE, Paul VJ, Corbett TH (2001). Total structure determination of apratoxin A, a potent novel cytotoxin from the marine cyanobacterium Lyngbya majuscula. J Am Chem Soc. 123:5418-5423.

Marshall KL, Vogt RL (1998). Illness associated with eating seaweed, Hawaii, 1994. Western J Med. 169:293-295.

Mitchell SS, Faulkner DJ, Rubins K, Bushman F (2000). Dolostatin 3 and two novel cyclic peptides from a Palauan collection of Lyngbya majuscula. J Nat Prod. 63:279-282.

Moikeha S, Chu G (1971). Dermatitis-producing alga Lyngbya majuscula Gomont in Hawaii. II. Biological properties of the toxic factor. J Phycol. 7:8-13.

Moore RE (1982). Toxins, anticancer agents, and tumor promoters from marine prokaryotes. Pure Appl Chem. 54:1919-1934.

Moore RE (1984). Public health and toxins from marine Blue- Green Algae. In: Ragelis E, editors: Seafood toxins. Washington (DC): American Chemical Society.

Moore RE, Blackman A, Cheuk C (1984). Absolute stereochemistries of the aplysiatoxins and oscillatoxin A. J Org Chem. 49:2484-2489.

Mynderse JS, Moore RE, Kashiwagi M, Norton TR (1977). Antileukemia activity in the Osillatoriaceae: isolation of Debromoaplysiatoxin from Lyngbya. Science. 196:538-540.

Nagai H, Yasumoto T, Hokama Y (1996). Aplysiatoxin and debromoaplysiatoxin as the causative agents of a red alga Gracilaria coronopifolia poisoning in Hawaii. Toxicon. 34:753-761.

Nagai H, Yasumoto T, Hokama Y (1997). Manauealides, some of the causative agents of a red alga Gracilaria coronopifolia poisoning in Hawaii. J Nat Prod. 60:925-928.

Nakamura H, Kishi Y, Pajares MA, Rando RR (1989). Structural basis of protein kinase C activation by tumor promoters. Proc Nat Acad Sci USA. 86:9672-9676.

Osborne N (2004). Investigation of the toxicology and public health aspects of the marine cyanobacterium, Lyngbya majuscula. Brisbane: Institution. 246 pp.

Osborne N, Webb P, Shaw G (2002). The toxicology and public health aspects of Lyngbya majuscula in Queensland, Australia. 10th International conference on harmful algae. WHO: St. Pete Beach (FL), USA: 221.

Osborne NJ, Seawright A, Shaw G (2008). Dermal Toxicology of Lyngbya majuscula, from Moreton Bay, Queensland, Australia. Harmful Algae. 7:584-589. 
Osborne NJ, Shaw GR (2008). Dermatitis associated with exposure to a marine cyanobacterium during recreational water exposure. BMC Dermatol. 8:5.

Osborne NJT, Shaw GR, Webb PM (2007). Health effects of recreational exposure to Moreton Bay, Australia waters during a Lyngbya majuscula bloom. Environ Int. 27:309-314.

Park PU, Broka CA, Johnson BF, Kishi Y (1987). Total synthesis of debromoaplysiatoxin and aplysiatoxin. J Am Chem Soc. 109:6205-6207.

Pennings SC, Weiss AM, Paul VJ (1996). Secondary metabolites of the cyanobacterium Microcoleus lyngbyaceus and the sea hare Stylocheilus longicauda: Palatability and toxicity. Mar Biol. 126:735-743.

Read JA, Walsh CT (2007) The lyngbyatoxin biosynthetic assembly line: chain release by four-electron reduction of a dipeptidyl thioester to the corresponding alcohol. J Am Chem Soc. 129:15762-15763.

Serdula M, Bartilini G, Moore RE, Gooch J, Wiebenga N (1982). Seaweed itch on windward Oahu. Hawaii Med J. 41:200-201.

Sims JK, Zandee van Rilland RD (1981). Escharotic stomatitis caused by the "stinging seaweed" Microcoleus lyngbyaceus (formerly Lyngbya majuscula). Case report and literature review. Hawaii Med J. 40:243-248.

Solomon AE, Stoughton RB (1978). Dermatitis from purified sea algae toxin (debromoaplysiatoxin). Arch Dermatol. 114:1333-1335.

Stafford RG, Mehta M, Kemppainen BW (1992). Comparison of the partition coefficient and skin penetration of a marine algal toxin (lyngbyatoxin A). Food Chem Toxicol. 30:795-801.

Todd JS, Gerwick WH (1995). Malyngamide I from the tropical marine cyanobacterium Lyngbya majuscula and the probable structure revision of stylocheilamide. Tetrahedron Lett. 36:7837-7840.

Tønder J, Hosseini M, Ahrenst A, Tanner D (2004). Studies of the formation of allcarbon quaternary centres, en route to lyngbyatoxin A. A comparison of phenyl and 7-substituted indole systems. Org Biomol Chem. 2:1447-1455.

Videau P, Wells KN, Singh AJ, Gerwick WH, Philmus B (2016). Assessment of Anabaena sp. strain PCC 7120 as a heterologous expression host for cyanobacterial natural products: production of lyngbyatoxin A. ACS Synth Biol. 5:978-988.

Yasumoto T (1998). Fish poisoning due to toxins of microalgal origins in the Pacific. Toxicon. 36:1515-1518. 


\title{
2.7 $\beta$-METHYLAMINO-L-ALANINE (BMAA)
}

\author{
Neil Chernoff, Elisabeth J. Faassen and Donna J. Hill
}

The nonproteinogenic amino acid, $\beta$-methylamino- $L$-alanine (BMAA; Figure 2.7), has been postulated to be a cause of neurodegenerative diseases that affect large numbers of people. However, at the time of publication of this document, this hypothesis is still highly controversial and a number of inconsistencies must be clarified before its role in human disease can be assessed with more certainty. The following section introduces and discusses these.

Interest in BMAA began as a result of a neurological disease known as amyotrophic lateral sclerosis/Parkinsonism dementia complex (ALS/PDC) present in the island of Guam in the Pacific (Arnold et al., 1953; Kurland et al., 1961). ALS/PDC has also been identified in small populations in Irian Jaya (western New Guinea) and Kii Peninsula of Japan. ALS/PDC has a spectrum of symptoms that resemble ALS, Parkinsonism and dementia. Different types of neurological dysfunctions were commonly present in the same individual, and multiple cases were often seen within families. The disease rendered patients incapable of normal movement, produced memory decline, cognitive deficits, and often led to premature death. In Guam, the peak incidence of the disease occurred during the 1950s and has been declining since then (Plato et al., 2002; Plato et al., 2003). The disease seemed limited to the indigenous population or others who had lived in Guam and adopted local customs and diet. ALS/PDC is characterised by hyperphosphorylated tau proteins that may assemble into masses ranging from a few molecules to large amyloid masses that may propagate like prions (Buée et al., 2000; Jucker \& Walker, 2013). The altered proteins form neurofibrillary tangles (NFTs), disrupting cell structure associated with loss of function and/or cell death (Walker \& LeVine, 2000; Chiti \& Dobson, 2006).

\subsection{Discrepancies introduced by incorrect BMAA analysis}

In order to evaluate the possible health risk of $\beta$-methylamino-L-alanine (BMAA), one of the crucial elements is an accurate estimation of BMAA levels in environmental and food samples, as well as in tissue of possibly

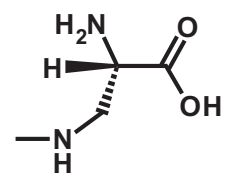

Figure 2.7 Structure of $\beta$-methylamino-L-alanine (BMAA). Molecular mass (monoisotopic): $118.074 \mathrm{Da}$; molecular weight (average): $118.13 \mathrm{~g} / \mathrm{mol}$. 
exposed humans. However, one of the major issues impacting the BMAA hypothesis is the use of nonspecific analytical techniques such as liquid chromatography fluorescence detection (LC-FLD) for quantification of BMAA in environmental and human tissue samples. The role of analytical chemistry in the BMAA-human neurodegenerative disease hypothesis is therefore explained first.

As experimentally shown (Faassen et al., 2012), LC-FLD analysis risks misidentification of BMAA. Some cyanobacterial samples tested positive for BMAA when analysed by LC-FLD, while the same samples tested negative when analysed by more reliable mass-specific analytical methods (e.g., liquid chromatography-tandem mass spectrometry, LC-MS/MS). This is in line with the differences found in the literature, in which studies that have used nonspecific analytical techniques for BMAA detection typically report higher percentages of positive samples and/or higher BMAA concentrations than mass spectrometry-based studies. There is now considerable data that indicates shortcomings with many of the analytical approaches used (Cohen, 2012; Faassen et al., 2012; Faassen, 2014; Faassen et al., 2016; Lage et al., 2016; Rosén et al., 2016).

Analytical issues seem to have resulted in a lack of replication in many of the key findings in the BMAA-neurodegenerative disease hypothesis, which will be discussed below. For instance, studies indicating the presence of BMAA in the brains of people who suffered from Alzheimer's disease or ALS (Murch et al., 2004a; Murch et al., 2004b; Pablo et al., 2009) used LC-FLD for quantification, and their results have not been replicated by more recent work using more reliable techniques. Similarly, the suggested universal occurrence of high concentrations of BMAA in cyanobacteria (Cox et al., 2005; Esterhuizen \& Downing, 2008; Metcalf et al., 2008) could not be replicated by studies using selective mass spectrometry techniques: these techniques either do not detect BMAA in cyanobacteria or find very low levels (Faassen, 2014; Lance et al., 2018). A key conclusion derived from this body of research is that LC-FLD, along with other optical detection methods that were used in early studies on BMAA in brain tissue, flying fox skin samples (Banack \& Cox, 2003a; Banack et al., 2006) and fish (Brand et al., 2010), is not sufficiently selective for BMAA identification and quantification, and should therefore not be used unless positive samples are verified and quantified with a more selective method like LC-MS/MS. An illustrative case in this respect is a study on BMAA concentrations in stranded dolphins (Davis et al., 2019). In this study, BMAA was reported from the brains of 13 of the 14 tested animals, in concentrations ranging from 20 up to $748 \mu \mathrm{g} / \mathrm{g}$, as quantified by LC-FLD. However, parallel LC-MS/MS analyses were only performed on 4 of the 14 samples, and the highest concentration found was $0.6 \mu \mathrm{g} / \mathrm{g}$. So although the abstract implies that two orthogonal methods were used throughout the study, for only 4 samples complementary results by LC-MS/MS were available. Moreover, the concentrations found by LC-MS/ 
MS, which can be found in the supplementary information, are a few orders of magnitude lower than the LC-FLD results reported in the main text, and the only sample that tested negative by LC-FLD tested positive by LC-MS/ MS. These discrepancies are not discussed in this chapter, which may leave the reader under the false impression that the high concentrations detected by LC-FLD are valid because they are supposedly confirmed by LC-MS/MS.

\subsubsection{The BMAA-human neurodegenerative disease hypothesis}

An epidemiological study related the incidence of ALS/PDC to the diets of the Guam population (Reed et al., 1987). Cycad seeds played a large role in the diet of the inhabitants of Guam, the seeds being ground up into flour that was a dietary staple. It was known that ingestion of seeds induced toxicity and they were carefully prepared with repeated washings before use as food but potent toxins like cycasin could be detected in cycad flour (Spencer, 2019). Vega et al. (1968) isolated a nonproteinogenic amino acid, BMAA, from seeds of cycad species utilised as food on Guam and found that it induced neurotoxicity when injected intraperitoneally at high dose levels into chickens or rats. Spencer et al. (1987b) exposed macaque monkeys (Macaca fascicularis) to $100-350 \mathrm{mg} \mathrm{BMAA} \cdot \mathrm{HCl} / \mathrm{kg}$ bw $\times \mathrm{d}$ orally, and observed stooped posture, tremors and weakness in extremities after a month at doses exceeding $200 \mathrm{mg} / \mathrm{kg}$. The amounts of BMAA administered to the monkeys were orders of magnitude greater than the amounts that would have been consumed by people in cycad flour, and a role of BMAA in ALS/PDC was dismissed (Duncan et al., 1990). Other chemicals associated with cycads have been suggested as possible causes of ALS/PDC, including cycasin (methoxymethanol; Spencer et al., 2012) and sterol glucosides (Ly et al., 2007). There was no evidence of cycad consumption in either Irian Jaya or Japan, but it was noted that both areas used cycads for medicinal purposes (Spencer et al., 1987a; Spencer et al., 2005).

Cox and Sacks (2002) postulated that ALS/PDC could be related to the consumption of cycasin and BMAA, produced by cycads, the seeds of which were then eaten by flying foxes (Pteropus mariannus) which were subsequently consumed by people (Banack et al., 2006). Cox et al. (2003) reported that symbiotic cyanobacteria (Nostoc spp.) in the coralloid roots of cycads produced BMAA and that this was subsequently transported and biomagnified to the outer layer of the seeds, a food item in the diet of flying foxes (Banack \& Cox, 2003a). High BMAA contents (mean $3.6 \mathrm{mg} / \mathrm{g}$ ) were reported from three desiccated skin samples of preserved flying foxes by LC-FLD (Banack \& Cox, 2003b), and the authors concluded that people in Guam consumed sufficient numbers of flying foxes to have been exposed to BMAA levels of a similar magnitude as those to which the monkeys in the experiments of Spencer et al. (1987b) were exposed. It was further suggested 
that the decline in the incidence of ALS/PDC was related to a decline in flying fox populations (Cox \& Sacks, 2002). However, the amount of flying foxes consumed by natives is in question since it was a food that appears to have been reserved for special occasions (Lemke, 1992). Borenstein et al. (2007) did not find any positive associations between cycad or flying fox consumption and ALS/PDC in Guam.

Another fundamental issue with this hypothesis is the findings of Foss et al. (2018) who tested skin samples from the identical three preserved flying foxes referred to in the study by Banack and Cox (2003a). LC-MS/MS was used for analysis and failed to identify BMAA in these samples although BMAA was successfully detected in positive controls and spiked samples. These findings support the point raised in section 2.7.1 that BMAA exposure should only be estimated from studies that used selective analytical techniques for identification and quantification.

$B M A A$ in cyanobacteria: The reports of BMAA in the symbiotic cyanobacteria Nostoc spp. in the coralloid roots of cycads raised the question of the source of BMAA. Using LC-FLD for quantification, Cox et al. (2005) examined cyanobacteria from different genera and found BMAA in 29 out of 30 the strains. They then postulated that, since BMAA was produced by most cyanobacteria, it should be considered to be a ubiquitous cyanotoxin. Subsequent studies have evaluated the ability of various genera and species of cyanobacteria to produce BMAA and reached different conclusions. Taking only studies into account that use selective, well-documented analytical techniques, reports of the presence of BMAA in cyanobacteria are scarce, and only incidentally, low concentrations are found in cyanobacterial samples (Faassen, 2014; Lance et al., 2018). It was found that BMAA can be produced by diatoms (Réveillon et al., 2016), but more studies are needed to estimate the range of BMAA concentrations in this type of phytoplankton.

Toxicological studies on monkeys and rats: Animal studies of BMAA exposures include primate studies carried out by Spencer et al. (1987b), as discussed above, and Cox et al. (2016) who reported on 32 adult vervet monkeys (Chlorocebus sabaeus) exposed orally to $21 \mathrm{mg} / \mathrm{kg} \times \mathrm{d}$ or $210 \mathrm{mg} /$ $\mathrm{kg} \times \mathrm{d}$ of $\beta$-methylamino-alanine (BMAA) for 140 days. Although effects are found in the $210 \mathrm{mg} / \mathrm{kg} \times \mathrm{d}$ group, this dose level is unrealistic in terms of any known source of BMAA or suggested route of human exposure.

BMAA concentrations reported from water samples analysed with accurate methods have demonstrated only very low levels when BMAA is detected at all (Lance et al., 2018), and ingestion of cyanobacterial infested waters therefore does not seem to be the most relevant human exposure pathway to BMAA. Considering the reported concentrations in fish and shellfish (Lance et al., 2018), consumption of these foodstuffs seems at present the most likely route of BMAA exposure. Using the data which were selected by Lance et al. (2018) based on their selectivity and well-described 
quantitation methods, a theoretical weekly human diet consisting of meals of $200 \mathrm{~g}$ fish for 6 days and $200 \mathrm{~g}$ shellfish for 1 day can be used to estimate the amount of BMAA that would be consumed. Assuming a weekly diet resulting in 6-day exposure of $58 \mu \mathrm{g}$ BMAA from fish and $540 \mu \mathrm{g}$ BMAA from a single exposure of shellfish for a total of $598 \mu \mathrm{g}$ yields an average daily intake of $85.4 \mu \mathrm{g}$. For a $60 \mathrm{-kg}$ individual, this would be equivalent to $1.42 \mu \mathrm{g} / \mathrm{kg} \times \mathrm{d}$. The dose of $21 \mathrm{mg} / \mathrm{kg} \times \mathrm{d}(21,000 \mu \mathrm{g} / \mathrm{kg} \times \mathrm{d})$ in vervet monkeys after 140 consecutive daily exposures, at which no adverse effects were observed (Cox et al., 2016), was $\approx 15,000$-fold higher. Other issues with the Cox et al.'s (2016) study are that at necropsy, brain homogenates of the vervets were analysed for the presence of BMAA and 14 regions of the brain were analysed for the presence of neurofibrillary tangles (NFT) and $\beta$-amyloid deposits. It was concluded that more NFTs were found in high-dose BMAA groups than in the low dose or controls (the data supplied in the paper and supplementary information do not allow estimates of individual variability within groups). In spite of the high dose, the behaviour of animals remained normal and they did not exhibit Parkinsonism or the muscular symptomology observed in the earlier macaque study by Spencer et al. (1987b), although the vervets studied by Cox et al. (2016) were exposed for 140 days, while the macaques studied by Spencer et al. (1987b) exhibited overt toxicity after being exposed to a similar dose only for approximately $45-75$ days.

A few rodent studies have been conducted on BMAA. BMAA administered to rats by oral route did not show effects at $500 \mathrm{mg} / \mathrm{kg} \times \mathrm{d}$ for approximately 32 days, or at $1000 \mathrm{mg} / \mathrm{kg}$ for approximately 15 days over the course of two months (Perry et al., 1989). BMAA administered to prepubertal rodents by either intraperitoneal $\geq 500 \mathrm{mg} / \mathrm{kg}$ (Seawright et al., 1990; de Munck et al., 2013) or subcutaneous route $\geq 460 \mathrm{mg} / \mathrm{kg}$ (Karlsson et al., 2009 ) is neurotoxic, but the inappropriate routes of administration and magnitude of the administered levels render these findings difficult to extrapolate to human exposures.

\subsubsection{ALSIPDC attributed to BMAA versus other manifestations of neurodegenerative disease}

An underlying assumption in the BMAA hypothesis of human ALS/PDC effects is that this syndrome encountered in Guam is closely related to other neurodegenerative diseases found globally, but there is evidence contradicting this assumption. Differences between ALS/PDC on Guam and ALS, Parkinsonism and Alzheimer's diseases include the strong familial occurrence (Zhang et al., 1996; Morris et al., 2001) and the common mixed disease syndrome seen in ALS/PDC on Guam (Murakami, 1999), both situations being extremely rare in the other neurological diseases. Additional characteristics indicating that ALS/PDC is distinct from sporadic ALS, 
Parkinsonism and Alzheimer's disease include the absence of beta-amyloid plaques that are characteristic of Alzheimer's disease, the absence of ubiquitinated Lewy bodies characteristic of Parkinsonism (Hirano et al., 1961), as well as the absence of the typical ALS/PDC tauopathy in sporadic ALS (Ikemoto, 2000). The individual symptomologies exhibited in ALS/PDC cases have been related to differences in the areas of the central nervous system where the highest densities of the aberrant tau proteins occurred (Hof et al., 1994; Umahara et al., 1994). One other significant difference between ALS/PDC and other neurodegenerative diseases is the presence of a retinal pigment epitheliopathy (RPE) that has only been reported in Guam and Kii Peninsula ALS/PDC cases (Kokubo et al., 2003). The condition manifests itself as linear tracks of retinal depigmentation with intermittent pigment clumping, and the incidence of RPE is significantly higher in ALS/PDC cases than in controls. RPE has not been associated with other diseases elsewhere in the world and is therefore considered part of the ALS/ PDC disease postulated to be caused by $\beta$-methylamino-alanine (BMAA) (Cox et al., 1989; Steele et al., 2015).

\subsubsection{Postulated human exposure and BMAA mechanism of action}

BMAA in brain tissue of humans: Reports of BMAA in brain tissue of humans who suffered neurodegenerative diseases are contradictory: three studies of postmortem human brain tissues from people on Guam who had suffered from ALS/PDC, or people in the United States of America and Canada who had either ALS or Alzheimer's disease, reported the presence of BMAA in disease sufferers (39 out of 40) irrespectively of where they had lived, whereas the studies rarely identified BMAA in people (four out of 36) who had not suffered from these neurodegenerative diseases (Murch et al., 2004a; Murch et al., 2004b; Pablo et al., 2009). These studies all utilised LC-FLD to quantify BMAA. In contrast, however, four studies that used mass spectrometry for identification and quantification of BMAA have not found similar incidences and/or levels in brains (Snyder et al., 2009; Combes et al., 2014; Meneely et al., 2016) or cerebrospinal fluids (Berntzon et al., 2015) of people who had suffered from Alzheimer's disease or ALS in the United States of America and Europe. Taking these last four studies together, BMAA was not found in any of 13 ALS/PDC brains/cerebrospinal fluids, and was found in one of 39 brains/ cerebrospinal fluids from people who had either ALS or Alzheimer's disease, as well as in three of 20 without disease. When only considering data on BMAA levels in brains or cerebrospinal fluids that have been generated by appropriate analytical techniques, there is little evidence for the hypothesis that BMAA is present in the brains of those suffering from ALS and Alzheimer's disease. 
Evidence of human exposure to BMAA has not been well documented. It has been suggested that a cluster of ALS cases in the United States of America was due to proximity to a lake and therefore exposure to BMAA, but this was not based on substantive evidence (Caller et al., 2009). A subsequent study did not show a general linkage between proximity to waterbodies and neurological disease (Caller et al., 2012). Suggestions have been made linking ALS to BMAA inhaled by soldiers in Qatar (Cox et al., 2009), the consumption of blue crabs (Field et al., 2013) and exposure to aerosols from cooling towers (Stommel et al., 2013), but clear evidence supporting these suggestions is not provided.

One of the central questions concerning the BMAA-neurodegenerative disease hypothesis concerns the mechanism by which BMAA would induce these diseases. Protein tangles and deposits are hallmarks of the neurodegenerative diseases discussed in this chapter (Ellisdon \& Bottomley, 2004; Jellinger, 2012; Bolshette et al., 2014). These tangles of misfolded proteins include tau proteins in Alzheimer's disease, ubiquinated proteins in ALS and Lewy bodies in Parkinsonism. Dunlop et al. (2013) stated that BMAA is misincorporated into human proteins in place of $L$-serine, but no direct evidence for this is presented. The reported association of BMAA with proteins is not necessarily indicative of incorporation and may simply be due to chemical binding. Glover et al. (2014) examined protein synthesis after coincubation of BMAA in a cell-free system (PURExpress) in studies where BMAA was substituted for individual essential amino acids. Although the interaction of BMAA and serine is highlighted, the data indicate that BMAA substitution for alanine occurred to a greater extent. BMAA was found to be significantly incorporated into proteins in place of four of the nine additional amino acids for which data are presented. These results may primarily be a reflection of the relaxed fidelity of translation of the PURExpress in vitro system, which has been used to facilitate misincorporation of amino acids (Hong et al., 2014; Singh-Blom et al., 2014).

In in vitro assays, Beri et al. (2017) and Han et al. (2020) observed that BMAA was not a substrate of human seryl-tRNA synthetase, and therefore, a misincorporation of BMAA instead of serine in proteins as postulated earlier is highly unlikely. Instead, Han et al. (2020) report that BMAA is a substrate for human alanyl-tRNA synthetase, however, with only low rates of product formation despite a 500 -fold higher concentration of BMAA compared to alanine. In an in vivo assay with Saccharomyces cerevisiae, an incorporation of BMAA instead of alanine could not be detected. Notably, the observed rates of mischarging of tRNA with BMAA are within the ranges generally observed for mischarging of aminoacyl-tRNA synthetases with noncognate amino acid - some $10^{-4}$ errors per codon or tRNA molecule, respectively (Mohler \& Ibba, 2017).

Other studies have failed to find indications of misincorporation of BMAA into proteins. van Onselen et al. (2015) compared BMAA and 
canavanine, a nonproteinogenic amino acid known for its tendency to be misincorporated in proteins. Protein incorporation was evaluated with an E. coli expression system using a fragment of a recombinant human protein. In contrast to canavanine, $\beta$-methylamino-alanine (BMAA) did not affect cell growth and was not detected in the protein fragment. The authors also showed that the removal of BMAA from bacterial proteins was not accomplished by washing with detergent-containing acid hydrolysis and TCA precipitation, indicating the probability of a strong association with protein surfaces. Similar findings were reported by Okle et al. (2012) who used a human neuroblastoma cell culture and demonstrated BMAA association with proteins after TCA protein precipitation, but not after protein-denaturing SDS gel electrophoresis. Spencer et al. (2016) did not find evidence to support the incorporation of BMAA into proteins in the brains of macaques. Cerebral protein lysates of BMAA-treated animals were analysed after extraction to remove BMAA from denatured proteins, detection was performed with LC-MS/MS, and no incorporation was found.

Rauk (2018) modelled protein folding changes that would have occurred if serine was substituted by BMAA. He concluded that BMAA incorporation instead of serine in proteins would not change conformational characteristics of the $\beta$-amyloid peptide and that BMAA was therefore not related to Alzheimer's disease.

\subsubsection{Conclusions}

The cause(s) of the ALS/PDC in Guam remains a mystery. The existence of the disease in Guam and Rota, but not in other areas where both flying foxes and cycad products are eaten, has not been satisfactorily explained. The possible relationship(s) between the presence of ALS/PDC in Guam, Irian Jaya and the Kii Peninsula remains unknown. Over the course of a decade, the BMAA hypothesis was transformed from one of many concerning the cause of a neurodegenerative disease that occurred on Guam and two other localities, to a global threat purportedly linked not only to ALS/ PDC, but also to ALS, Alzheimer's disease and Parkinsonism.

The BMAA-neurodegenerative disease hypothesis is built on four major contentions:

1. BMAA was the primary cause of ALS/PDC due to high levels in food in Guam.

2. The disease is sufficiently similar to ALS, Parkinsonism and Alzheimer's disease to enable BMAA to cause all of these diseases.

3. The environmental/dietary exposure levels outside of Guam are sufficient to cause this disease in humans.

4. BMAA acts through its incorporation into proteins displacing serine. 
While this hypothesis may be appealing for its simplicity and universality, these contentions are either disputed by many other studies, or the necessary data to support the hypothesis are not presented. The hypothesis that BMAA caused ALS/PDC was largely based on a primate study that used extremely high dose levels which were postulated to be possible for humans to obtain by the consumption of food with extremely high levels of BMAA. ALS/PDC is a separate neurodegenerative disease that has occurred in several geographically distant and distinct areas. While the sum of its symptoms are similar to other neurodegenerative diseases, the patterns of occurrence are different, the type of aberrant proteins and regions of the brain that are affected are different, and there is no reason for assuming that the same agent acts to induce all of these diseases. Moreover, it seems that human BMAA exposure through food and environment outside Guam is orders of magnitude lower than effective doses administered in animal studies, or postulated to have been consumed by people on Guam. Finally, several well-designed studies have failed to find evidence of BMAA incorporation into proteins.

Research into the cause(s) of ALS/PDC has largely been focused on single factors, but there is little evidence that any of the single factor hypotheses are completely responsible for the disease. There is, however, a possibility that all or most of the different postulated causes, along with the considerable stress on the population of Guam during the World War II occupation, played additive or synergistic roles in the occurrence of ALS/PDC, and a more complex causation should be considered. Mineral imbalance, genetic background, stress-induced physiological alterations and any of several toxins present in cycads may have all played significant roles in the causation of the disease (Chernoff et al., 2017). To solve a problem of this nature is extremely difficult under any circumstances, and this difficulty may increase as the incidence of ALS/PDC lessens in Guam. The evidence for BMAA being the single cause of ALS/PDC in Guam as well as for other unrelated neurodegenerative diseases globally is not convincing.

One can never realistically prove the absence of an effect, but the totality of the evidence for the BMAA-neurodegenerative disease hypothesis at the present time, or better the lack thereof, gives no reasons for immediate concern. The question of mechanisms explaining how one compound can cause four distinctive neurological diseases affecting different regions of the brain and having different proteins associated with the central nervous system changes in different people is a major issue that has yet to be addressed experimentally. BMAA remains an interesting compound, but given the evidence of increasing cyanobacterial and marine algal blooms and various associated toxins in numerous waterbodies globally, there are many other more apparent potential algal toxin health effect issues. Research efforts on BMAA should be balanced with regard to those on the other cyanotoxins. 
Although solid exposure data are required for risk assessment, the key question that needs to be answered first is whether the proposed toxic effects of BMAA can be confirmed in health-relevant dose ranges.

\section{REFERENCES}

Arnold A, Edgren DC, Palladino VS (1953). Amyothrophic Lateral Sclerosis: fifty cases observed on Guam. J Nerv Ment Dis. 117:135-139.

Banack SA, Cox PA (2003a). Biomagnification of cycad neurotoxins in flying foxes: implications for ALS-PDC in Guam. Neurology. 61:387-389.

Banack SA, Cox PA (2003b). Distribution of the neurotoxic nonprotein amino acid BMAA in Cycas micronesica. Bot J Linn Soc. 143:165-168.

Banack SA, Murch SJ, Cox PA (2006). Neurotoxic flying foxes as dietary items for the Chamorro people, Marianas Islands. J Ethnopharmacol. 106:97-104.

Beri J, Nash T, Martin RM, Bereman MS (2017). Exposure to BMAA mirrors molecular processes linked to neurodegenerative disease. Proteomics. 17:1700161.

Berntzon L, Ronnevi L, Bergman B, Eriksson J (2015). Detection of BMAA in the human central nervous system. Neuroscience. 292:137-147.

Bolshette N, Thakur K, Bidkar A, Trandafir C, Kumar P, Gogoi R (2014). Protein folding and misfolding in the neurodegenerative disorders: a review. Revue Neurologique. 170:151-161.

Borenstein A, Mortimer J, Schofield E, Wu Y, Salmon D, Gamst A et al. (2007). Cycad exposure and risk of dementia, MCI, and PDC in the Chamorro population of Guam. Neurology. 68:1764-1771.

Brand LE, Pablo J, Compton A, Hammerschlag N, Mash DC (2010). Cyanobacterial Blooms and the Occurrence of the neurotoxin beta-N-methylamino-L-alanine (BMAA) in South Florida Aquatic Food Webs. Harmful Algae. 9:620-635.

Buée L, Bussière T, Buée-Scherrer V, Delacourte A, Hof PR (2000). Tau protein isoforms, phosphorylation and role in neurodegenerative disorders. Brain Res Rev. 33:95-130.

Caller TA, Doolin JW, Haney JF, Murby AJ, West KG, Farrar HE et al. (2009). A cluster of amyotrophic lateral sclerosis in New Hampshire: a possible role for toxic cyanobacteria blooms. Amyotroph Lateral Scler. 10 (Suppl 2):101-108.

Caller TA, Field NC, Chipman JW, Shi X, Harris BT, Stommel EW (2012). Spatial clustering of amyotrophic lateral sclerosis and the potential role of BMAA. Amyotroph Lateral Scler. 13:25-32.

Chernoff N, Hill D, Diggs D, Faison B, Francis B, Lang J et al. (2017). A critical review of the postulated role of the non-essential amino acid, $\beta$-N-methylamino-Lalanine, in neurodegenerative disease in humans. J Toxicol Environ Health Part B. 20:183-229.

Chiti F, Dobson CM (2006). Protein misfolding, functional amyloid, and human disease. Annu Rev Biochem. 75:333-366.

Cohen SA (2012). Analytical techniques for the detection of $\alpha$-amino- $\beta$ methylaminopropionic acid. Analyst. 137:1991-2005.

Combes A, El Abdellaoui S, Vial J, Lagrange E, Pichon V (2014). Development of an analytical procedure for quantifying the underivatized neurotoxin $\beta-\mathrm{N}$ methylamino-L-alanine in brain tissues. Anal Bioanal Chem. 406:4627-4636. 
Cox PA, Banack SA, Murch SJ (2003). Biomagnification of cyanobacterial neurotoxins and neurodegenerative disease among the Chamorro people of Guam. Proc Natl Acad Sci USA. 100:13380-13383.

Cox PA, Banack SA, Murch SJ, Rasmussen U, Tien G, Bidigare RR et al. (2005). Diverse taxa of cyanobacteria produce beta-N-methylamino-L-alanine, a neurotoxic amino acid. Proc Natl Acad Sci USA. 102:5074-5078.

Cox PA, Davis DA, Mash DC, Metcalf JS, Banack SA (2016). Dietary exposure to an environmental toxin triggers neurofibrillary tangles and amyloid deposits in the brain. Proc R Soc B. Biol Sci. 283:2015-2397.

Cox PA, Richer R, Metcalf JS, Banack SA, Codd GA, Bradley WG (2009). Cyanobacteria and BMAA exposure from desert dust: a possible link to sporadic ALS among Gulf War veterans. Amyotroph Lateral Scler. 10:109-117.

Cox PA, Sacks OW (2002). Cycad neurotoxins, consumption of flying foxes, and ALS-PDC disease in Guam. Neurology. 58:956-959.

Cox TA, McDarby JV, Lavine L, Steele JC, Calne DB (1989). A retinopathy on Guam with high prevalence in Lytico-Bodig. Ophthalmology. 96:1731-1735.

Davis DA, Mondo K, Stern E, Annor AK, Murch SJ, Coyne TM et al. (2019). Cyanobacterial neurotoxin BMAA and brain pathology in stranded dolphins. PloS One. 14:e0213346.

de Munck E, Muñoz-Sáez E, Miguel BG, Solas MT, Ojeda I, Martínez A et al. (2013). $\beta$-N-methylamino-l-alanine causes neurological and pathological phenotypes mimicking Amyotrophic Lateral Sclerosis (ALS): the first step towards an experimental model for sporadic ALS. Environ Toxicol Pharmacol. 36:243-255.

Duncan MW, Steele JC, Kopin IJ, Markey SP (1990). 2-Amino-3-(methylamino)propanoic acid (BMAA) in cycad flour An unlikely cause of amyotrophic lateral sclerosis and parkinsonism-dementia of Guam. Neurology. 40:767-767.

Dunlop RA, Cox PA, Banack SA, Rodgers KJ (2013). The non-protein amino acid BMAA is misincorporated into human proteins in place of L-serine causing protein misfolding and aggregation. PLoS One. 8:e75376.

Ellisdon AM, Bottomley SP (2004). The role of protein misfolding in the pathogenesis of human diseases. IUBMB life. 56:119-123.

Esterhuizen M, Downing TG (2008). Beta-N-methylamino-L-alanine (BMAA) in novel South African cyanobacterial isolates. Ecotoxicol Environ Safety. 71:309-313.

Faassen EJ (2014). Presence of the neurotoxin BMAA in aquatic ecosystems: what do we really know? Toxins. 6:1109-1138.

Faassen EJ, Antoniou MG, Beekman-Lukassen W, Blahova L, Chernova E, Christophoridis C et al. (2016). A collaborative evaluation of LC-MS/MS based methods for BMAA analysis: Soluble bound BMAA found to be an important fraction. Mar Drugs. 14:45.

Faassen EJ, Gillissen F, Lürling M (2012). A comparative study on three analytical methods for the determination of the neurotoxin BMAA in cyanobacteria. PLoS One. 7:e36667.

Field NC, Metcalf JS, Caller TA, Banack SA, Cox PA, Stommel EW (2013). Linking $\beta$-methylamino-L-alanine exposure to sporadic amyotrophic lateral sclerosis in Annapolis, MD. Toxicon. 70:179-183.

Foss AJ, Chernoff N, Aubel MT (2018). The analysis of underivatized $\beta$-MethylaminoL-alanine (BMAA), BAMA, AEG \& 2, 4-DAB in Pteropus mariannus mariannus specimens using HILIC-LC-MS/MS. Toxicon. 152:150-159. 
Glover WB, Mash DC, Murch SJ (2014). The natural non-protein amino acid N- $\beta$ methylamino-L-alanine (BMAA) is incorporated into protein during synthesis. Amino Acids. 46:2553-2559.

Han N-C, Bullwinkle TJ, Loeb KF, Faull KF, Mohler K, Rinehart J et al. (2020). The mechanism of $\beta$-N-methylamino-l-alanine inhibition of tRNA aminoacylation and its impact on misincorporation. J Biol Chem. 295:1402-1410.

Hirano A, Malamud N, Kurland LT (1961). Parkinsonism-dementia complex, an endemic disease on the island of Guam. II Pathological features. Brain. 84:662-679.

Hof PR, Perl DP, Loerzel AJ, Steele JC, Morrison JH (1994). Amyotrophic lateral sclerosis and parkinsonism-dementia from Guam: differences in neurofibrillary tangle distribution and density in the hippocampal formation and neocortex. Brain Res. 650:107-116.

Hong SH, Kwon Y-C, Jewett MC (2014). Non-standard amino acid incorporation into proteins using Escherichia coli cell-free protein synthesis. Front Chem. 2:34.

Ikemoto AH, Ichiro Akiguchi A (2000). Neuropathology of amyotrophic lateral sclerosis with extra-motor system degeneration: characteristics and differences in the molecular pathology between ALS with dementia and Guamanian ALS. Amyotroph Lateral Scler Other Motor Neuron Disord. 1:97-104.

Jellinger KA (2012). Interaction between pathogenic proteins in neurodegenerative disorders. J Cell Mol Med. 16:1166-1183.

Jucker M, Walker LC (2013). Self-propagation of pathogenic protein aggregates in neurodegenerative diseases. Nature. 501:45.

Karlsson O, Roman E, Brittebo EB (2009). Long-term cognitive impairments in adult rats treated neonatally with beta-N-methylamino-L-alanine. Toxicol Sci. 112:185-195.

Kokubo Y, Ito K, Kuzuhara S (2003). Ophthalmomyiasis-like pigmentary retinopathy in ALS/PDC in the Kii peninsula of Japan. Neurology. 60:1725-1726.

Kurland L, Hirano A, Malamud N, Lessell S (1961). Parkinsonism-dementia complex, en endemic disease on the island of Guam. Clinical, pathological, genetic and epidemiological features. Trans Am Neurol Assoc. 86:115-120.

Lage S, Burian A, Rasmussen U, Costa PR, Annadotter H, Godhe A et al. (2016). BMAA extraction of cyanobacteria samples: which method to choose? Environ Sci Pollut Res. 23:338-350.

Lance E, Arnich N, Maignien T, Biré R (2018). Occurrence of $\beta$-N-methylamino-1alanine (BMAA) and isomers in aquatic environments and aquatic food sources for humans. Toxins. 10:83.

Lemke TO (1992). History of fruit bat use, research, and, protection in the Northern Mariana Islands. Biol Rep, US Fish Wild Serv. 90:135-142.

Ly P, Singh S, Shaw C (2007). Novel environmental toxins: Steryl glycosides as a potential etiological factor for age-related neurodegenerative diseases. J Neurosci Res. 85:231-237.

Meneely JP, Chevallier OP, Graham S, Greer B, Green BD, Elliott CT (2016). $\beta$-methylamino-L-alanine (BMAA) is not found in the brains of patients with confirmed Alzheimer's disease. Sci Rep. 6: 36363.

Metcalf JS, Banack SA, Lindsay J, Morrison LF, Cox PA, Codd GA (2008). Co-occurrence of beta-N-methylamino-L-alanine, a neurotoxic amino acid with other cyanobacterial toxins in British waterbodies, 1990-2004. Environ Microbiol. 10:702-708. 
Mohler K, Ibba M (2017). Translational fidelity and mistranslation in the cellular response to stress. Nat Microbiol. 2:1-9.

Morris HR, Al-Sarraj S, Schwab C, Gwinn-Hardy K, Perez-Tur J, Wood NW et al. (2001). A clinical and pathological study of motor neurone disease on Guam. Brain. 124:2215-2222.

Murakami N (1999). Parkinsonism-dementia complex on Guam-overview of clinical aspects. J Neurol. 246:II16-18.

Murch SJ, Cox PA, Banack SA (2004a). A mechanism for slow release of biomagnified cyanobacterial neurotoxins and neurodegenerative disease in Guam. Proc Natl Acad Sci USA. 101:12228-12231.

Murch SJ, Cox PA, Banack SA, Steele JC, Sacks OW (2004b). Occurrence of betamethylamino-l-alanine (BMAA) in ALS/PDC patients from Guam. Acta Neurol Scand. 110:267-269.

Okle O, Stemmer K, Deschl U, Dietrich DR (2012). L-BMAA induced ER stress and enhanced caspase 12 cleavage in human neuroblastoma SH-SY5Y cells at low nonexcitotoxic concentrations. Toxicol Sci. 131:217-224.

Pablo J, Banack SA, Cox PA, Johnson TE, Papapetropoulos S, Bradley WG et al. (2009). Cyanobacterial neurotoxin BMAA in ALS and Alzheimer's disease. Acta Neurologica Scandinavica. 120:216-225.

Perry TL, Bergeron C, Biro AJ, Hansen S (1989). $\beta$-N-Methylamino-L-alanine: chronic oral administration is not neurotoxic to mice. J Neurol Sci. 94:173-180.

Plato C, Galasko D, Garruto R, Plato M, Gamst A, Craig U-K et al. (2002). ALS and PDC of Guam Forty-year follow-up. Neurology. 58:765-773.

Plato CC, Garruto RM, Galasko D, Craig UK, Plato M, Gamst A et al. (2003). Amyotrophic lateral sclerosis and parkinsonism-dementia complex of Guam: changing incidence rates during the past 60 years. Am J Epidemiol. 157:149-157.

Rauk A (2018). $\beta$-N-Methylamino-l-alanine (BMAA) Not Involved in Alzheimer's Disease. J Phys Chem B. 122:4472-4480.

Reed D, Labarthe D, Chen KM, Stallones R (1987). A cohort study of amyotrophic lateral sclerosis and parkinsonism-dementia on Guam and Rota. Am J Epidemiol. 125:92-100.

Réveillon D, Séchet V, Hess P, Amzil Z (2016). Production of BMAA and DAB by diatoms (Phaeodactylum tricornutum, Chaetoceros sp., Chaetoceros calcitrans and, Thalassiosira pseudonana) and bacteria isolated from a diatom culture. Harmful Algae. 58:45-50.

Rosén J, Westerberg E, Schmiedt S, Hellenäs K-E (2016). BMAA detected as neither free nor protein bound amino acid in blue mussels. Toxicon. 109:45-50.

Seawright A, Brown A, Nolan C, Cavanagh J (1990). Selective degeneration of cerebellar cortical neurons caused by cycad neurotoxin, L- $\beta$-methylaminoalanine (L-BMAA), in rats. Neuropathol Appl Neurobiol. 16:153-169.

Singh-Blom A, Hughes RA, Ellington AD (2014). An amino acid depleted cell-free protein synthesis system for the incorporation of non-canonical amino acid analogs into proteins. J Biotechnol. 178:12-22.

Snyder L, Cruz-Aguado R, Sadilek M, Galasko D, Shaw C, Montine T (2009). Lack of cerebral BMAA in human cerebral cortex. Neurology. 72:1360-1361.

Spencer P, Fry RC, Kisby GE (2012). Unraveling 50-year-old clues linking neurodegeneration and cancer to cycad toxins: are microRNAs common mediators? Front Genet. 3:192. 
Spencer P, Garner C, Palmer V, Kisby G (2016). Vervets and macaques: similarities and differences in their responses to L-BMAA. Neurotoxicology. 56:284-286.

Spencer P, Ohta M, Palmer V (1987a). Cycad use and motor neurone disease in Kii peninsula of Japan. Lancet. 330:1462-1463.

Spencer PS (2019). Hypothesis: etiologic and molecular mechanistic leads for sporadic neurodegenerative diseases based on experience with Western Pacific ALS/PDC. Front Neurol. 10.

Spencer PS, Nunn PB, Hougon J, Ludolph AC, Roy DN, Ross SM et al. (1987b). Guam amyotrophic lateral sclerosis-parkinsonism-dementia linked to a plant excitant neurotoxin. Science. 237:517-523.

Spencer PS, Palmer VS, Ludolph AC (2005). On the decline and etiology of highincidence motor system disease in West Papua (southwest New Guinea). Mov Disord. 20:S119-S126.

Steele JC, Wresch R, Hanlon SD, Keystone J, Ben-Shlomo Y (2015). A unique retinal epitheliopathy is associated with amyotrophic lateral sclerosis/ParkinsonismDementia complex of Guam. Mov Disord. 30:1271-1275.

Stommel EW, Field NC, Caller TA (2013). Aerosolization of cyanobacteria as a risk factor for amyotrophic lateral sclerosis. Med Hypotheses. 80:142-145.

Umahara T, Hirano A, Kato S, Shibata N, Yen S-H (1994). Demonstration of neurofibrillary tangles and neuropil thread-like structures in spinal cord white matter in parkinsonism-dementia complex on Guam and in Guamanian amyotrophic lateral sclerosis. Acta Neuropathol. 88:180-184.

van Onselen R, Cook NA, Phelan RR, Downing TG (2015). Bacteria do not incorporate $\beta$-N-methylamino-L-alanine into their proteins. Toxicon. 102:55-61.

Vega A, Bell E, Nunn P (1968). The preparation of L-and D- $\alpha$-amino- $\beta$ methylaminopropionic acids and the identification of the compound isolated from Cycas circinalis as the L-isomer. Phytochemistry. 7:1885-1887.

Walker LC, LeVine H (2000) The cerebral proteopathies. Mol Neurobiol. 21:83-95. Zhang Z, Anderson D, Mantel N, Roman G (1996). Motor neuron disease on Guam: geographic and familial occurrence, 1956-85. Acta Neurologica Scandinavica. 94:51-59. 


\title{
2.8 CYANOBACTERIAL LIPOPOLYSACCHARIDES (LPS)
}

\author{
Martin Welker
}

\subsection{General characteristics of bacterial LPS}

Lipopolysaccharides (LPS) are part of the outer membrane of most Gramnegative prokaryotes, including enteric bacteria (Erridge et al., 2002; Raetz \& Whitfield, 2002) and also cyanobacteria (Weckesser et al., 1979; Martin et al., 1989). Furthermore, there is evidence that LPS-like compounds can be found in green algae (Armstrong et al., 2002) and chloroplasts of vascular plants (Armstrong et al., 2006). A large body of literature is available on the structure, composition of LPS and their association with adverse health effects, generally focusing on heterotrophic bacteria of clinical relevance (Dauphinee \& Karsan, 2006; Bryant et al., 2010; Vatanen et al., 2016).

The structure of all LPS generally follows the scheme given in Figure 2.8. The core structure is highly complex with individual regions showing varying degrees of conservation. In particular, the O-polysaccharide chain is highly variable and is the main characteristic for distinguishing dozens or hundreds of serotypes in some bacterial species, for example, Escherichia coli or Salmonella sp. (Stenutz et al., 2006). The moiety primarily responsible for the toxicity is lipid A, which is composed of phosphorylated sugar units to which acyl chains of variable length and degree of saturation are linked. Cyanobacterial LPS is different to LPS from Gram-negative heterotrophs as it often lacks heptose and 3-deoxy-D-manno-octulosonic acid (or keto-deoxyoctulosonate; KDO), which are commonly present in the core region of the LPS of heterotrophic bacteria. However, since the number of

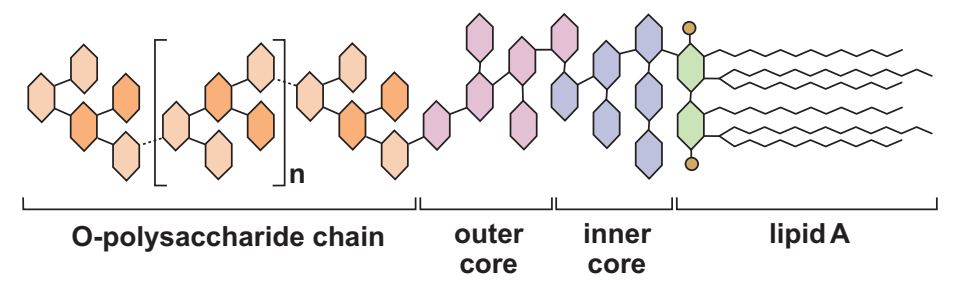

Figure 2.8 Schematic structure of lipopolysaccharides. Lipid A is composed of a highly conserved $D$-glucosamine backbone with variable acyl chains bound to it, the particular structure of which largely determines endotoxicity. The inner core is also highly conserved containing KDO and heptoses, that are, however, less frequent or absent in cyanobacterial LPS. The outer core is moderately variable and contains mostly common sugars such as hexoses or hexaminoses. The O-polysaccharide chain is composed of repetitive units of sugar complexes and is highly variable and responsible for the serological specificity of LPS and is a primary antigen of infective bacteria. (Modified from Erridge et al., 2002.) 
well-characterised LPS from cyanobacteria is very limited, species-specific characteristics cannot yet be derived (Durai et al., 2015).

The first cyanobacterial LPS were characterised from two strains of marine Synechococcus sp. (Snyder et al., 2009). Structural elucidation of LPS is also available from "Oscillatoria planktothrix", confirming the lack of KDO (Carillo et al., 2014). The monosaccharide composition of the O-chain of Microcystis sp. LPS was found to be relatively simple (Fujii et al., 2012). Further reports characterise cyanobacterial LPS rather by its bioactivity and less by analyses of chemical structures.

In the literature, the terms "LPS" and "endotoxin" are often used as synonyms, but not always. Occasionally, endotoxin refers to the lipid A part of LPS or refers to an entirely different molecule that is released from cells only upon lysis. The lipid A of different heterotrophic bacterial species is highly variable and expectedly exhibits varying activity in various test systems (Erridge et al., 2002) - as it is presumably the case with cyanobacterial lipid A (Gemma et al., 2016).

The principal clinical relevance of LPS from heterotrophic bacteria is due to its role in sepsis and septic shock, which are potentially life-threatening conditions leading to high numbers of casualties every year worldwide (Hotchkiss et al., 2016). Most cases of endotoxin intoxication occur after systemic infection with Gram-negative bacteria that can lead to sepsis and septic shock when endotoxin is released from cells and enters the blood circuit. There, LPS triggers a signalling cascade in macrophage/endothelial cells that eventually secrete proinflammatory compounds such as cytokines and nitric oxide (Trent et al., 2006).

In particular, LPS is known to bind to one type of so-called toll-like receptors, namely, TLR4 (Bryant et al., 2010), triggering a cascade of cellular reactions that involve the regulation of the expression of a large number of genes (Akira \& Takeda, 2004). In healthy individuals, the recognition of LPS by TLR4 triggers innate and adaptive immune responses as part of the normal defence against invasive microbes (Takeda et al., 2003), and only a massive reaction in response to LPS in the bloodstream leads to a critical health status. The strength of the binding of LPS to TLR4 is dependent on the structure of lipid A, explaining varying strength of reactions in patients but also in bioassays. The cascading host response to LPS rather than the toxic properties of LPS itself therefore accounts for the potentially lethal consequences (Opal, 2010). For this reason, LPS (or endotoxin) has been discussed to be classified rather as an (exogenous) hormone than as a toxin in a strict sense (Marshall, 2005). Arguably, LPS is not a secondary metabolite like the known cyanotoxins but a highly variable fraction of a cellular constituent rather than a defined structure.

One precondition of LPS-mediated sepsis is the microbial infection of a body part causing an immune response and, when not controlled, inflammation. The presence of bacteria producing LPS in or on the body is no 
health risk in itself (Mowat \& Agace, 2014). The LPS contained in a healthy gut microbiome is generally no threat and exceeds by far the amount of LPS that triggers a septic shock when circulating in the bloodstream.

Besides their role in acute and life-threatening conditions, LPS play an important role in triggering various signalling pathways in epithelial cells, for example, in the intestine (Cario et al., 2000) or the lung (Guillot et al., 2004). However, the role of LPS (from heterotrophic bacteria) in the regulation of the gut microbiome (d'Hennezel et al., 2017) - the complexity of which has only recently been fully recognised - is beyond the scope of this chapter and the following will focus on cyanobacterial LPS.

\subsubsection{What is known about bioactivity of cyanobacterial LPS?}

A number of studies on cyanobacterial lipopolysaccharides (LPS) have demonstrated effects in bioassays, for example:

- Mayer et al. (2011) reported several metabolic reactions of rat microglia upon exposure to LPS from Microcystis. However, the reactions were considerably less pronounced compared to the reactions observed upon exposure to equimolar concentrations of LPS from Escherichia coli.

- Klemm et al. (2018) reported similar reactions of rat microglia in vitro after exposure to LPS from Scytonema.

- Best et al. (2002) quantified the activities of microsomal and soluble glutathione S-transferases (GST) from zebra fish embryos exposed to LPS from an axenic Microcystis strain, cyanobacterial blooms and enteric bacteria. They found a reduction in activity for all types of LPS and concluded that this may reduce the detoxication capacity for microcystins.

- Jaja-Chimedza et al. (2012) also exposed zebra fish embryos to extracts of Microcystis strains assumed to contain LPS and found an increase in activity of glutathione-based detoxication enzymes.

- Ohkouchi et al. (2012) exposed a human monocytic cell line to LPS from various heterotrophic and cyanobacteria as well as from microbial consortia to test the inflammatory potential of LPS. The LPSs from an Acinetobacter lwoffii culture and from bacterial consortia induced stronger reactions than other LPSs tested, including that of cyanobacteria.

- Macagno et al. (2006) isolated "an LPS like compound" from "Oscillatoria planktothrix" that acts as a selective inhibitor of activity induced in dendritic cells through exposure to LPS from E. coli. This antagonistic behaviour was found to inhibit LPS-induced toxic shock in mice. In Limulus amoebocyte lysate (LAL) assays, activity of the cyanobacterial LPS-like compound was very low at $4 \mathrm{EU} / \mu \mathrm{g}$ compared to $8000 \mathrm{EU} / \mu \mathrm{g}$ 
of Salmonella enterica serotype abortus equi LPS or $15000 \mathrm{EU} / \mathrm{\mu g}$ of Escherichia coli serotype 055:B5 LPS.

- This cyanobacterial LPS-like compound is a potential inhibitor of Escherichia coli LPS-induced inflammatory response in porcine whole blood (Thorgersen et al., 2008).

- Moosova et al. (2019) report a number of proinfammatory effects of LPS extracted from Microcystis strains and bloom samples observed in whole-blood in vitro assays, such as induction inflammatory mediators like tumor necrosis factor and interleukins.

These in vitro studies demonstrate a wide variety of bioactivities in a number of test systems; yet it is difficult to infer potential in vivo bioactivity from these results, especially as to date no study has unambiguously related cyanobacterial LPS to adverse health effects in mammals, including humans, in vivo, like this has been demonstrated for microcystin toxicity, for example. Gastrointestinal disorders upon ingestion of cyanobacteria, generally consisting of heterogeneous bloom material, cannot be causally attributed to cyanobacterial LPS as is discussed below.

In most studies that imply an association between observed adverse human health effects and cyanobacterial LPS, this is based more on associative argumentation than on conclusive evidence. Mainly two reports have been influential in advancing the hypothesis that cyanobacterial LPS is a health risk.

Lippy and Erb (1976) reported on an outbreak of gastrointestinal illness that occurred in Sewickley, PA (USA). The epidemiological survey conducted at the time concluded that the outbreak was a water-borne illness and a putative contaminant was thought to have entered the water supply system through an uncovered finished-water reservoir in which cyanobacteria (mainly Schizothrix) were present around the time of the outbreak. Although the term "endotoxin" is used only once and only in the context of a general recommendation without making an explicit link to cyanobacteria, in subsequent studies the outbreak is retrospectively linked more or less explicitly to cyanobacterial lipopolysaccharides (Keleti et al., 1979; Sykora et al., 1980). At the time of the outbreak, many aetiological agents were not yet known or were not yet detectable, and hence, the conclusions drawn were possibly influenced by the visible prominence of cyanobacterial blooms compared to, for example, viruses. Also, none of the cyanobacterial toxins with unambiguous adverse health effects treated in this volume were known at the time of this outbreak.

Hindman et al. (1975) reported on an outbreak of pyrogenic reactions in patients being treated at a haemodialysis clinic in Washington, DC. They circumstantially attributed this to cyanobacterial LPS as a cyanobacterial bloom was present in the Potomac River from which the raw water was abstracted. The apparent reason for this connection is that the authors were 
unable to demonstrate bacterial infections and bacterial contamination of tap water and dialysate was seen only at trace levels. The authors concluded that raw water from the Potomac, affected by a concurrent "algae bloom", was the likely source of LPS or endotoxin. However, no samples were taken to obtain counts of heterotrophs in the raw water (or in the treatment system). In this case also, the connection of cyanobacterial LPS to the adverse health effect is possibly largely based on the prominent visibility of an "algal bloom" - rather than on unequivocal evidence.

Since these early reports, no further studies have unequivocally supported the hypothesis that cyanobacterial LPS poses a risk to human health. Nonetheless, these studies were cited as evidence for this hypothesis until recently. In most of the reports that attribute signs and symptoms to contact with cyanobacterial lipopolysaccharides, as summarised in Stewart et al. (2006), this connection is not well evidenced or given only in general terms such as that "cyanobacterial toxins or LPS can cause adverse health effects".

A study by Lévesque et al. (2016), entitled "Exposure to cyanobacteria: acute health effects associated with endotoxins", suggests a causal relationship between exposure to cyanobacterial LPS (endotoxin) and human illness. The observed health effects consisted of generally mild gastrointestinal symptoms not requiring medical examination. Yet, the statement made in the title is not well supported by the presented data. For example, no information is provided on the taxonomic composition of the cyanobacterial blooms, nor have well-known cyanobacterial toxins been quantified. Further, no attempt was made to analyse water samples for possible heterotrophic pathogens associated with the cyanobacteria - while the authors clearly state that "the hypothesis of a preponderant role of Gram-negative bacteria is attractive" (see also next section) and conclude that "it is possible that the concentration of endotoxins is a proxy of another exposure". In summary, the reported correlation between exposure to cyanobacterial blooms and mild disease does not allow to conclude that specifically cyanobacterial LPS actually played a significant role in this.

\subsubsection{Methodological problems of studies on cyanobacterial LPS}

Due to their structural complexity, the quantification of LPS in a (cyano) bacterial sample is difficult, and instead of a true molar or gravimetric quantification, a bioassay has been employed. Most studies used the Limulus amoebocyte lysate (LAL) assay (Young et al., 1972), with intrinsic uncertainty due to varying activity of LPS from individual strains. The validity of the LAL assay for clinical diagnosis has long been debated due to a supposed lack of specificity but it is still considered the gold standard. Alternatively, pyrogen tests based on human monocytoid cells have been proposed (Hoffmann et al., 
2005). Modern biosensor-based assays are increasingly available (Das et al., 2014; Lim et al., 2015), while modifications of the LAL assay are still in use to detect LPS in clinical samples (e.g., Wong et al., 2016).

The characterisation of LPS from cyanobacteria can only be meaningful if these are extracted from axenic cyanobacterial cultures, that is, cultures free of any contamination with heterotrophic bacteria. Effects of LPS extracted from samples of cyanobacterial blooms cannot be attributed exclusively to cyanobacterial LPS because in field samples, a high diversity of heterotrophic bacteria in high numbers is tightly associated with cyanobacterial cells (Kolmonen et al., 2004; Xie et al., 2016; Yang et al., 2017). Even if the biomass of cyanobacteria in such environmental bloom samples is higher than that of the heterotrophic bacteria, their relative share of LPS is lower because LPS content correlates with cell surface rather than with cell volume. A large number of small heterotrophic bacteria has a higher cell surface than the corresponding biomass of cyanobacteria, so that heterotrophic bacteria are likely to contain more LPS per biomass than cyanobacteria. In consequence, a relevant fraction of the activity in LAL bioassays of field samples is likely partly due to LPS from heterotrophic bacteria (Bláhová et al., 2013).

Considering the highly variable activity of lipopolysaccharides (LPS) of different microbiological origin, a mixture of LPS from an unquantified consortium of (cyano)bacteria does not allow a meaningful toxicological evaluation of one particular and unquantified LPS in this mixture. Bláhová et al. (2013) analysed LPS extracted from cultured Microcystis strains and from blooms dominated by Microcystis. In the latter, the authors reported higher activity (in LAL assays) and concluded that this is due to the contribution of noncyanobacterial LPS. Rapala et al. (2006) also reported LPS fractions from axenic strains to show a much lower endotoxic activity than LPS fractions from bloom samples dominated by the same species. The same reservation may, although to a lesser extent, also apply to clonal but nonaxenic cultures of cyanobacteria in which the diversity of heterotrophs may be low but their cell numbers can be high and hence also the share of noncyanobacterial LPS in extracts. Interestingly, Moosova et al. (2019) report the opposite, that is, higher activity of LPS extracted from axenic strains compared to LPS from bloom samples. Therefore, unless respective studies explicitly state that cyanobacterial LPS was extracted from an axenic strain, a contamination with heterotrophic LPS needs to be considered when interpreting results.

Heterotrophic bacteria associated with cyanobacterial blooms may not only contribute to the combined amount of LPS but prove to be more important as a direct cause for adverse health effects than the cyanobacteria biomass itself (Berg et al., 2011). For example, Vibrio cholerae (Chaturvedi et al., 2015) or Legionella spp. (Taylor et al., 2009), the very presence of which may constitute a health risk, have been found associated with cyanobacterial blooms. 
LPS in samples is generally reported in endotoxin units per volume (e.g., $\mathrm{EU} / \mathrm{mL}$ ) or per mass of LPS (e.g., EU/mg) with endotoxin units not directly correlated with the gravimetric amount of LPS due to the high variability of less conserved parts of the molecule. Some LPS may consist of a high share of Lipid A, while for others this share may be lower due to a higher share of polysaccharide moieties. Hence, it is very important to understand what the terms "endotoxin", "LPS" or "endotoxic activity" refer to in particular publications. "LPS" is generally reported in gravimetric units, while "endotoxin" is reported either as activity, for example, in Limulus amoebocyte lysate (LAL) assays, or in gravimetric units when used synonymous to "LPS".

In most bioassay studies, cyanobacterial LPS has been extracted from cells or samples with organic solvents, generally phenol, and the residue is considered to consist of LPS but often without a further characterisation in terms of purity testing or (partial) structure elucidation. This means that in most studies a fraction of not fully characterised composition is used rather than a defined compound. This is further complicated by the fact that LPS from an individual strain may be a mixture of structural variants. Among Gram-negative bacteria, variations of the polysaccharide chain (Michael et al., 2005) as well as of lipid A (Darveau et al., 2004) have been reported for individual strains.

The extraction procedure to obtain purified LPS needs to be optimised for the particular species under study and may even vary in efficiency when comparing multiple strains of a single species, as Papageorgiou et al. (2004) showed for multiple Microcystis strains. For toxigenic cyanobacterial strains, the extraction of LPS is further complicated by the possibility of coextraction of toxins such as microcystins that may bias bioassays when not properly quantified (Lindsay et al., 2009).

\subsubsection{Possible exposure routes to cyanobacterial LPS}

As discussed above, lipopolysaccharides (LPS) from bacterial heterotrophs becomes a critical health issue when it is released from tissue infections or inflammations and enters the bloodstream. Routes for exposure to cyanobacterial LPS are quite different from such clinical cases: systemic infections with cyanobacteria are very unlikely and have never been reported (in contrast to infections with green algae such as nonautotroph Prototheca spp.); thus, an increase of LPS from multiplication of cyanobacteria in the human body can be excluded.

Exposure to cyanobacterial LPS only appears to be possible via the intestinal tract after oral uptake (cells and free LPS), during dialysis (free LPS) or via the respiratory mucosa after inhalation (cells and free LPS). In a review on possible exposure of humans to LPS through drinking-water, Anderson et al. (2002) concluded that two major exposure routes to LPS 
through drinking-water exist, namely, haemodialysis and inhalation, while other exposure routes such as oral ingestion or skin contact are considered as not being relevant: "occurrences linked to ingestion or through dermal abrasions could not be located" - for LPS neither from heterotrophic bacteria nor from cyanobacterial LPS. Also, the uptake of cyanobacterial LPS through the consumption of cyanobacteria contained in blue green algal dietary supplements or food items (Aphanizomenon, Arthrospira, Nostoc; see section 5.5) so far has not been considered as a health risk. Therefore, possible exposure routes to cyanobacterial LPS can be restricted to haemodialysis and inhalation.

For haemodialysis, it is evident that any exposure to cyanobacterial metabolites and other compounds must be avoided (see section 5.4) and the question whether cyanobacterial LPS pose a threat or not is likely outweighed by the proven direct adverse effect of cyanobacterial toxins such as microcystins. Compared to cyanobacterial toxins, cyanobacterial LPS is presumably of lesser relevance for dialysis-associated health risks, and any measure to avoid exposure to cyanotoxins will inherently also address cyanobacterial LPS.

Inhalation of cyanobacterial LPS remains as a possible exposure route to be considered. The exposure to LPS through inhalation is generally considered to act through free LPS (Anderson et al., 2002). For drinking-water, Gram-negative heterotrophs are generally considered the main source of LPS as these bacteria can proliferate within the treatment system, for example, as biofilms on filters or in distribution pipes from which LPS can be released after cell death. In contrast, cyanobacterial cells are generally removed from raw water at the initial stages of water treatment (see Chapter 10) and cannot or only extremely rarely proliferate in the distribution system. Therefore, respiratory contact to cyanobacteria occurs primarily through intact cells or cell fragments inhaled accidentally during recreational or occupational activity. Inhalation of intact cyanobacterial cells or cell debris may have various effects such as mechanical irritation, tissue damage due to toxins or secondary infections with associated microorganisms (see also section 5.2). Clear evidence of a contribution of cyanobacterial LPS to adverse health effects upon inhalation of cyanobacteria has not been published so far.

\subsubsection{Conclusions}

There is no doubt that LPS from cyanobacteria affects cell lines or subcellular systems such as the Limulus amoebocyte lysate assay in a similar way to LPS from heterotrophic bacteria. However, from this bioactivity in vitro, it cannot be concluded that LPS in waterbodies is a human health risk per se. LPS contained in aquatic ecosystems, with or without cyanobacteria, are a source of the natural and constant exposure to LPS - as it is the case with 
LPS contained in the human gut and skin microbiomes, neither of which pose a direct health risk.

During effective drinking-water treatment, cyanobacterial LPS concentration is very unlikely to increase in the process. Therefore, the exposure to cyanobacterial LPS via consumption of drinking-water as potential health risk can be negated with a fair amount of certainty. Exposure to cyanobacterial LPS via inhalation may equally be irrelevant when considering spray formation, for example, while showering.

Inhalation of spray of water containing cyanobacteria in substantial amounts could be an exposure scenario but most adverse health effects such as inflammation or tissue lesions likely are a consequence of other constituents rather than an effect of cyanobacterial LPS itself. For haemodialysis, water needs to be free not only of any LPS but also of any cyanobacterial toxins to avoid critical exposure and health risks, as described in section 5.4 , and ensuring that will inherently include LPS.

In summary, based on the current knowledge, cumulated in several decades of research, cyanobacterial LPS are not likely to pose health risks to an extent known from toxins like microcystins or cylindrospermopsins, in particluar, when considering plausible exposure pathways.

\section{REFERENCES}

Akira S, Takeda K (2004). Toll-like receptor signalling. Nat Rev Immunol. 4:499.

Anderson WB, Slawson RM, Mayfield CI (2002). A review of drinking-waterassociated endotoxin, including potential routes of human exposure. Can J Microbiol. 48:567-587.

Armstrong MT, Theg SM, Braun N, Wainwright N, Pardy R, Armstrong PB et al. (2006). Histochemical evidence for lipid A (endotoxin) in eukaryote chloroplasts. FASEB J. 20:2145-2146.

Armstrong PB, Armstrong MT, Pardy R, Child A, Wainwright N (2002). Immunohistochemical demonstration of a lipopolysaccharide in the cell wall of a eukaryote, the green alga, Chlorella. Biol Bull. 203:203-204.

Berg KA, Lyra C, Niemi RM, Heens B, Hoppu K, Erkomaa K et al. (2011). Virulence genes of Aeromonas isolates, bacterial endotoxins and cyanobacterial toxins from recreational water samples associated with human health symptoms. J Water Health. 9:670-679.

Best JH, Pflugmacher S, Wiegand C, Eddy FB, Metcalf JS, Codd GA (2002). Effects of enteric bacterial and cyanobacterial lipopolysaccharides, and of microcystinLR, on glutathione S-transferase activities in zebra fish (Danio rerio). Aquat Toxicol. 60:223-231.

Bláhová L, Adamovský O, Kubala L, Šindlerová LŠ, Zounková R, Bláha L (2013). The isolation and characterization of lipopolysaccharides from Microcystis aeruginosa, a prominent toxic water bloom forming cyanobacteria. Toxicon. 76:187-196. 
Bryant CE, Spring DR, Gangloff M, Gay NJ (2010). The molecular basis of the host response to lipopolysaccharide. Nat Rev Microbiol. 8:8.

Carillo S, Pieretti G, Bedini E, Parrilli M, Lanzetta R, Corsaro MM (2014). Structural investigation of the antagonist LPS from the cyanobacterium Oscillatoria planktothrix FP1. Carbohydr Res. 388:73-80.

Cario E, Rosenberg IM, Brandwein SL, Beck PL, Reinecker H-C, Podolsky DK (2000). Lipopolysaccharide activates distinct signaling pathways in intestinal epithelial cell lines expressing Toll-like receptors. J Immunol. 164:966-972.

Chaturvedi P, Agrawal MK, Bagchi SN (2015). Microcystin-producing and nonproducing cyanobacterial blooms collected from the Central India harbor potentially pathogenic Vibrio cholerae. Ecotoxicol Environ Saf. 115:67-74.

d'Hennezel E, Abubucker S, Murphy LO, Cullen TW (2017). Total lipopolysaccharide from the human gut microbiome silences toll-like receptor signaling. MSystems. 2:e00046-e00017.

Darveau RP, Pham T-TT, Lemley K, Reife RA, Bainbridge BW, Coats SR et al. (2004). Porphyromonas gingivalis lipopolysaccharide contains multiple lipid A species that functionally interact with both toll-like receptors 2 and 4. Infect Immun. 72:5041-5051.

Das A, Kumar P, Swain S (2014). Recent advances in biosensor based endotoxin detection. Biosens Bioelectron. 51:62-75.

Dauphinee SM, Karsan A (2006). Lipopolysaccharide signaling in endothelial cells. Lab Invest. 86:9.

Durai P, Batool M, Choi S (2015). Structure and effects of cyanobacterial lipopolysaccharides. Mar Drugs. 13:4217-4230.

Erridge C, Bennett-Guerrero E, Poxton IR (2002). Structure and function of lipopolysaccharides. Microbes Infect. 4:837-851.

Fujii M, Sato Y, Ito H, Masago Y, Omura T (2012). Monosaccharide composition of the outer membrane lipopolysaccharide and O-chain from the freshwater cyanobacterium Microcystis aeruginosa NIES-87. J Appl Microbiol. 113:896-903.

Gemma S, Molteni M, Rossetti C (2016). Lipopolysaccharides in Cyanobacteria: A brief overview. Adv Microbiol. 6:391.

Guillot L, Medjane S, Le-Barillec K, Balloy V, Danel C, Chignard M et al. (2004). Response of human pulmonary epithelial cells to lipopolysaccharide involves Toll-like Receptor 4 (TLR4)-dependent signaling pathways. J Biol Chem. 279:2712-2718.

Hindman SH, Favero MS, Carson LA, Petersen NJ, Schonberger LB, Solano JT (1975). Pyrogenic reactions during haemodialysis caused by extramural endotoxin. Lancet. 2:732-734.

Hoffmann S, Peterbauer A, Schindler S, Fennrich S, Poole S, Mistry Y et al. (2005). International validation of novel pyrogen tests based on human monocytoid cells. J Immunol Meth. 298:161-173.

Hotchkiss RS, Moldawer LL, Opal SM, Reinhart K, Turnbull IR, Vincent J-L (2016). Sepsis and septic shock. Nat Rev Dis Primers. 2:16045.

Jaja-Chimedza A, Gantar M, Mayer GD, Gibbs PD, Berry JP (2012). Effects of cyanobacterial lipopolysaccharides from Microcystis on glutathione-based detoxification pathways in the zebrafish (Danio rerio) embryo. Toxins. 4:390-404. 
Keleti G, Sykora J, Lippy E, Shapiro M (1979). Composition and biological properties of lipopolysaccharides isolated from Schizothrix calcicola (Ag.) Gomont (Cyanobacteria). Appl Environ Microbiol. 38:471-477.

Klemm LC, Czerwonka E, Hall ML, Williams PG, Mayer A (2018). Cyanobacteria Scytonema javanicum and Scytonema ocellatum lipopolysaccharides elicit release of superoxide anion, matrix-metalloproteinase- 9 , cytokines and chemokines by rat microglia in vitro. Toxins. 10:130.

Kolmonen E, Sivonen K, Rapala J, Haukka K (2004). Diversity of cyanobacteria and heterotrophic bacteria in cyanobacterial blooms in Lake Joutikas, Finland. Aquat Microb Ecol. 36:201-211.

Lévesque B, Gervais M-C, Chevalier P, Gauvin D, Anassour-Laouan-Sidi E, Gingras S et al. (2016). Exposure to cyanobacteria: acute health effects associated with endotoxins. Public Health. 134:98-101.

Lim SK, Chen P, Lee FL, Moochhala S, Liedberg B (2015). Peptide-assembled graphene oxide as a fluorescent turn-on sensor for lipopolysaccharide (endotoxin) detection. Anal Chem. 87:9408-9412.

Lindsay J, Metcalf J, Codd G (2009). Comparison of four methods for the extraction of lipopolysaccharide from cyanobacteria. Toxicol Environ Chem. 91:1253-1262.

Lippy EC, Erb J (1976). Gastrointestinal illness at Sewickley, PA. J Am Water Works Assoc. 68:606-610.

Macagno A, Molteni M, Rinaldi A, Bertoni F, Lanzavecchia A, Rossetti C et al. (2006). A cyanobacterial LPS antagonist prevents endotoxin shock and blocks sustained TLR4 stimulation required for cytokine expression. J Exp Med. 203:1481-1492.

Marshall JC (2005). Lipopolysaccharide: an endotoxin or an exogenous hormone? Clin Infect Dis. 41:S470-S480.

Martin C, Codd GA, Siegelman HW, Weckesser J (1989). Lipopolysaccharides and polysaccharides of the cell envelope of toxic Microcystis aeruginosa strains. Arch Microbiol. 152:90-94.

Mayer AM, Clifford JA, Aldulescu M, Frenkel JA, Holland MA, Hall ML et al. (2011). Cyanobacterial Microcystis aeruginosa lipopolysaccharide elicits release of superoxide anion, thromboxane B2, cytokines, chemokines, and matrix metalloproteinase-9 by rat microglia. Toxicol Sci. 121:63-72.

Michael FS, Li J, Vinogradov E, Larocque S, Harper M, Cox AD (2005). Structural analysis of the lipopolysaccharide of Pasteurella multocida strain VP161: identification of both Kdo-P and Kdo-Kdo species in the lipopolysaccharide. Carbohydr Res. 340:59-68.

Mowat AM, Agace WW (2014). Regional specialization within the intestinal immune system. Nat Rev Immunol. 14:667.

Moosová Z, Šindlerová L, Ambrůzová B, Ambrožová G, Vašíček O, Velki M et al. (2019) Lipopolysaccharides from Microcystis cyanobacteria-dominated water bloom and from laboratory cultures trigger human immune innate response. Toxins 11:218.

Ohkouchi Y, Tajima S, Nomura M, Itoh S (2012). Comparison of inflammatory responses in human cells caused by lipopolysaccharides from Escherichia coli and from indigenous bacteria in aquatic environment. J Environ Sci Health Part A. 47:1966-1974. 
Opal SM (2010). Endotoxins and other sepsis triggers. In: Ronco C, Piccinni P, Rosner MH, editors: Endotoxemia and endotoxin shock: disease, diagnosis and therapy. Basel: Karger Publishers:14-24.

Papageorgiou J, Linke TA, Kapralos C, Nicholson BC, Steffensen DA (2004). Extraction of cyanobacterial endotoxin. Environ Toxicol. 19:82-87.

Raetz CRH, Whitfield C (2002). Lipopolysaccharide endotoxins. Annu Rev Biochem. 71:635-700.

Rapala J, Niemelä M, Berg K, Lepistö L, Lahti K (2006). Removal of cyanobacteria, cyanotoxins, heterotrophic bacteria and endotoxins at an operating surface water treatment plant. Wat Sci Technol. 54:23-28.

Snyder DS, Brahamsha B, Azadi P, Palenik B (2009). Structure of compositionally simple lipopolysaccharide from marine Synechococcus. J Bacteriol. 191:5499-5509.

Stenutz R, Weintraub A, Widmalm G (2006). The structures of Escherichia coli O-polysaccharide antigens. FEMS Microbiol Rev. 30:382-403.

Stewart I, Schluter PJ, Shaw GR (2006). Cyanobacterial lipopolysaccharides and human health - a review. BMC Environ Health. 5:1-23.

Sykora JL, Keleti G, Roche R, Volk DR, Kay GP, Burgess RA et al. (1980). Endotoxins, algae and Limulus amoebocyte lysate test in drinking water. Water Res. 14:829-839.

Takeda K, Kaisho T, Akira S (2003). Toll-like receptors. Annu Rev Immunol. 21: 335-376.

Taylor M, Ross K, Bentham R (2009). Legionella, protozoa, and biofilms: interactions within complex microbial systems. Microb Ecol. 58:538-547.

Thorgersen EB, Macagno A, Rossetti C, Mollnes TE (2008). Cyanobacterial LPS antagonist (CyP)-A novel and efficient inhibitor of Escherichia coli LPSinduced cytokine response in the pig. Mol Immunol. 45:3553-3557.

Trent MS, Stead CM, Tran AX, Hankins JV (2006). Invited review: diversity of endotoxin and its impact on pathogenesis. J Endotoxin Res. 12:205-223.

Vatanen T, Kostic AD, d'Hennezel E, Siljander H, Franzosa EA, Yassour M et al. (2016). Variation in microbiome LPS immunogenicity contributes to autoimmunity in humans. Cell. 165:842-853.

Weckesser J, Drews G, Mayer H (1979). Lipopolysaccharides of photosynthetic prokaryotes. Annu Rev Microbiol. 33:215-239.

Wong J, Davies N, Jeraj H, Vilar E, Viljoen A, Farrington K (2016). A comparative study of blood endotoxin detection in haemodialysis patients. J Inflammation. 13:24.

Xie M, Ren M, Yang C, Yi H, Li Z, Li T et al. (2016). Metagenomic analysis reveals symbiotic relationship among bacteria in Microcystis-dominated community. Front Microbiol. 7:56.

Yang C, Wang Q, Simon PN, Liu J, Liu L, Dai X et al. (2017). Distinct network interactions in particle-associated and free-living bacterial communities during a Microcystis aeruginosa bloom in a Plateau lake. Front Microbiol. 8:1202.

Young NS, Levin J, Prendergast RA (1972). An invertebrate coagulation system activated by endotoxin: evidence for enzymatic mediation. J Clin Invest. 51:1790-1797. 


\title{
2.9 CYANOBACTERIAL TASTE AND ODOUR COMPOUNDS IN WATER
}

\author{
Triantafyllos Kaloudis
}

Cyanobacteria can produce a large number of odorous compounds in water that are usually referred to as water "taste and odour" (T\&O) compounds, some of which are specific to cyanobacteria, while others, however, are also produced by other organisms. Odorous metabolites have negative effects especially for drinking-water systems, as they make water unacceptable for consumers but also for tourism, recreational uses and aquaculture enterprises.

Cyanobacterial T\&O compounds belong to various chemical groups, including terpenoids, ionones, aldehydes, ketones, sulphurous compounds, amines and others (Watson, 2004). Among these, the most frequently occurring compounds that are associated with seriously unpleasant episodes of off-odours in source waters and water supplies are geosmin and 2-methylisoborneol (MIB).

Geosmin (from the Greek "geo": earth and "osme": odour) is a bicyclic sesquiterpenic compound with an extremely intense muddy/earthy smell that has an odour threshold concentration (OTC, i.e., minimum concentration detected by human nose) of about $4 \mathrm{ng} / \mathrm{L}$ in water, while MIB is a bicyclic terpenoid with a strong musty odour and an OTC of $6 \mathrm{ng} / \mathrm{L}$ (Young et al., 1996). Geosmin and MIB are responsible for many T\&O incidents affecting water supplies, recreational waters and tourism, and they can also accumulate in the lipid tissue of aquatic organisms, for example, of fish, resulting in economic losses to fishery and aquaculture enterprises (Smith et al., 2008).

Many other odorous compounds can be produced by cyanobacteria, such as $\beta$-cyclocitral, $\alpha$ - and $\beta$-ionones and alkyl sulphides (Jüttner, 1984). This section focuses on the most commonly occurring, that is, geosmin and MIB.

\subsection{Chemistry and toxicity}

Figure 2.9 shows the chemical structures of common cyanobacterial T\&O compounds and their characteristic odour. Geosmin and MIB are both tertiary alcohols belonging to the class of terpenoids. Only the (-) enantiomers occur in natural systems, and these are more odorous than the (+) enantiomers (Jüttner \& Watson, 2007).

Geosmin and MIB are not considered as health hazards for humans, as it has been shown that environmentally relevant concentrations of both compounds (e.g., ng- $\mu \mathrm{g} / \mathrm{L}$ ) present no cytotoxicity or genotoxicity (Dionigi et al., 1993; Bláha et al., 2004; Burgos et al., 2014). Furthermore, as these compounds can be sensed by the human nose at extremely low concentrations (low ng/L, see above; Table 2.10), their presence even in low concentrations 
(a)<smiles>C[C@H]1CCC[C@]2(C)CCCC[C@]12O</smiles>

(d)<smiles>CC(=O)/C=C/C1=C(C)CCCC1(C)C</smiles>

(b)<smiles>CC1(C)[C@H]2C[C@](C)(O)[C@@]1(C)C2(C)C</smiles>

(e)<smiles>CC(=O)/C=C/C1C(C)=CCCC1(C)C</smiles>

(c)<smiles>CC1=CCCC(C)(C)C1C=O</smiles>

(f)<smiles>CSSC</smiles>

Figure 2.9 Chemical structures of geosmin (a), methyl-isoborneol (b), $\beta$-cyclocitral (c), $\beta$-ionone (d), $\alpha$-ionone (e), and dimethyl-disulphide (f). For molecular weights and smell characteristics, see Table 2.I0.

makes water unacceptable for consumption, which is the main problem they cause for water supplies. Indirectly, the presence of T\&O may affect health if it leads consumers to turn to another, possibly less safe water supply. Other compounds such as $\beta$-cyclocitral and $\alpha, \beta$-ionones, which are carotenoid breakdown products, also do not pose health safety concerns; in fact, they are used as additives in food or in cosmetic products.

\subsubsection{Analysis}

Sensory evaluation followed by chemical analysis is generally used for the assessment of T\&O compounds produced by cyanobacteria in water (Suffet et al., 2004). Flavour profile analysis (FPA) is a useful sensory evaluation technique, in which a panel of trained assessors describes the character and intensity of the unusual odour (Rice et al., 2017). Panellists can use the water

Table 2.10 Smell characteristics and molecular weights of common cyanobacterial taste and odour substances

\begin{tabular}{llcc}
\hline & \multicolumn{1}{c}{$\begin{array}{c}\text { Smell } \\
\text { characteristics }\end{array}$} & $\begin{array}{c}\text { Monoisotopic mass } \\
(\mathrm{Da})\end{array}$ & $\begin{array}{c}\text { Molecular weight } \\
(\mathrm{g} / \mathrm{mol})\end{array}$ \\
\hline Geosmin & Earthy-muddy & 182.17 & 182.31 \\
2-Methylisoborneol & Musty-mouldy & 168.15 & 168.28 \\
$\beta$-Cyclocitral & Tobacco/wood & 152.12 & 152.24 \\
$\beta$-lonone & Violets & 192.15 & 192.30 \\
$\alpha$-lonone & Violets & 192.15 & 192.30 \\
Dimethyl disulphide & Septic & 93.99 & 94.20 \\
\hline
\end{tabular}


“Taste and Odour Wheel” (TOW) to associate odour descriptions with groups of chemical compounds that are included in sectors of the TOW. Several sectors contain compounds that are possibly produced by cyanobacteria; for example, earthy/mouldy/musty odours are associated with the sector that contains geosmin and 2-methylisoborneol (MIB) as possible causative agents. The results of FPA-TOW provide guidance for the chemical analysis laboratory regarding which groups of compounds should be specifically targeted.

Detection, identification and quantitation of geosmin, MIB and other T\&O compounds is carried out by gas chromatography combined with mass spectrometry (GC-MS). GC-MS techniques, after sample extraction and preconcentration, allow detection and quantitation of T\&O at very low concentrations (low $\mathrm{ng} / \mathrm{L}$ ). Confirmation of the identity of odorous compounds is based on mass spectral analysis, retention indices and comparisons with commercially available standards. GC-olfactometry (GC-O) is a supplementary technique, especially for nontargeted analysis, that can provide additional information to identify the compound(s) responsible for the unusual odour (Hochereau \& Bruchet, 2004). Efficient extraction of geosmin, MIB and other T\&O compounds from water prior to GC-MS can be achieved by techniques such as purge and trap (P\&T), solid-phase extraction (SPE), head-space solid-phase microextraction (HS-SPME), stirbar sorptive extraction (SBSE) and closed-loop stripping analysis (CLSA). These techniques can be optimised so that detection at concentrations below or equal to OTCs can be achieved (Kaloudis et al., 2017).

Molecular methods targeting geosmin and MIB biosynthetic genes of cyanobacteria have been developed and can be applied as additional monitoring tools for the early detection of geosmin and MIB producers in aquatic environments (Giglio et al., 2010; Su et al., 2013; Suurnäkki et al., 2015).

\subsubsection{Producing organisms}

In aquatic environments, cyanobacteria are considered as the major sources of geosmin and MIB, although these compounds are also produced by actinomycetes that are nonphotosynthetic and largely terrestrial organisms associated with soils (Watson, 2004). Odour compounds from actinomycetes can be washed into surface waterbodies but this process seems to be less relevant in water T\&O episodes (Zaitlin \& Watson, 2006).

Compilations of cyanobacterial species that produce geosmin and MIB show a variety of primarily filamentous planktonic and benthic producers (Jüttner \& Watson, 2007; Krishnani et al., 2008; Smith et al., 2008; Graham et al., 2010). Geosmin- and MIB-producing species belong to the genera Dolichospermum (Anabaena), Oscillatoria, Phormidium, Lyngbya, Leptolyngbya, Microcoleus, Nostoc, Planktothrix, Pseudanabaena, Hyella and Synechococcus. Most of the cyanobacterial species of these genera produce either geosmin or MIB, but there are also species capable of 
producing both compounds. Similarly to cyanotoxins, production of T\&O compounds by cyanobacteria is strain-dependent; therefore, strain isolation and culture or detection of specific gene clusters are required to conclusively identify the T\&O producers.

\subsubsection{Biosynthesis}

Geosmin and MIB are synthesised by terpene synthases. Geosmin is synthesised through cyclisation of farnesyl diphosphate by geosmin synthase (Jiang et al., 2008). MIB is synthesised through methylation of geranyl diphosphate by a methyltransferase, followed by cyclisation to MIB by MIB synthase (Komatsu et al., 2008). The genes associated with biosynthesis of geosmin and MIB from cyanobacteria have been discovered, and this has led to the development of PCR and qPCR methods for the detection of cyanobacteria producers (Suurnäkki et al., 2015). The functions of cyanobacterial T\&O compounds for the cells are still largely unknown. It is hypothesised that they may have a role as signalling compounds, in allelopathic interactions or as defensive agents (Zuo, 2019).

\subsubsection{Geosmin and MIB concentrations in aquatic environments}

The concentrations of geosmin and MIB found in aquatic environments can vary widely, but they are usually below $1 \mu \mathrm{g} / \mathrm{L}$ in surface waters and considerably lower in treated drinking-water. Similarly to cyanotoxins, geosmin, MIB and other cyanobacterial T\&O compounds can be cell-bound or dissolved in water, and there is no general consensus in the literature regarding the methods used to discriminate between these fractions or regarding the expression of results (Jüttner \& Watson, 2007).

The production and occurrence of cyanobacterial T\&O compounds are known to be influenced by various environmental factors, including phytoplankton composition, light intensity, nutrient concentrations, water temperature, $\mathrm{pH}$ and dissolved oxygen. Study of these factors is useful for the development of predictive models for T\&O incidents (Qi et al., 2012). Geosmin and MIB persist in water and are both only slowly degraded by chemicals or microorganisms, which largely explains their persistence in conventional water treatment processes.

\subsubsection{Removal of geosmin and MIB by water treatment processes}

Removal of geosmin, MIB and other T\&O compounds from water is a great challenge for water utilities, due to the extremely low odour threshold concentrations (OTCs) of some compounds. Conventional water treatment methods (coagulation, flocculation, sedimentation and filtration) are 
generally ineffective in removing geosmin and MIB from drinking-water. Adsorption with activated carbon (AC), in granular (GAC) or powdered (PAC) forms, is widely used to remove T\&O compounds. PAC especially provides the flexibility of application for seasonal, short-term or unexpected T\&O episodes. Several factors, including the adsorbent properties such as pore size distribution and surface characteristics and the presence of natural organic matter (NOM) in water, can reduce the effectiveness of removal due to competitive adsorption (Newcombe et al., 2002). Furthermore, biodegradability of geosmin and MIB by several microorganisms has been studied and has been used for biological filtration on sand filters or GAC (Ho et al., 2007).

Common disinfectants and oxidants (e.g., $\mathrm{Cl}_{2}, \mathrm{ClO}_{2}, \mathrm{KMnO}_{4}$ ) may not completely remove T\&O compounds or they may form other odorous byproducts, while ozone and a combination of ozone/hydrogen peroxide are shown to be more efficient (Bruchet et al., 2004; Peter \& Von Gunten, 2007). A number of studies have focused on the degradation of geosmin and MIB using advanced oxidation processes such as $\mathrm{UV} / \mathrm{H}_{2} \mathrm{O}_{2}, \mathrm{O}_{3} / \mathrm{H}_{2} \mathrm{O}_{2}$, heterogeneous photocatalysis and sonolysis (Antonopoulou et al., 2014; Fotiou et al., 2015). Degradation mechanisms in advanced oxidation processes commonly proceed via the oxidation of T\&O compounds by highly reactive oxygen species such as the hydroxyl radical; thus, they are generally more effective than conventional oxidation. However, their application is rather limited mainly due to operational costs.

Such special treatment requires additional investment and operational costs. As cyanobacterial T\&O episodes are often seasonal or occasional, modelling the temporal and spatial dynamics of cyanobacteria in water reservoirs in order to prevent and control the growth of producer organisms is therefore considered the most efficient practice for water supplies.

\subsubsection{Co-occurrence of T\&O compounds and cyanotoxins}

Not all cyanobacteria produce toxins and T\&O compounds, but, as shown in section 2.9.4, several genera contain one or more cyanotoxin and/or T\&O strain producers. Some strains of Microcystis also produce microcystins together with $\beta$-cyclocitral and alkyl sulphides (Jüttner, 1984). However, cyanobacterial T\&O compounds do not inevitably indicate the occurrence of cyanotoxins, since attempts to use T\&O parameters as potential indicators of the presence of the toxins have been inconclusive (Khiari, 2017). Nevertheless, when T\&O incidents occur in water supplies that use surface water reservoirs, both operators and authorities should be aware that cyanobacteria are a possible cause. As T\&O compounds can be sensed at very low concentrations, they can serve as an early warning for further investigations regarding the presence of cyanobacteria and among them, possible cyanotoxin producers. 


\section{REFERENCES}

Antonopoulou M, Evgenidou E, Lambropoulou D, Konstantinou I (2014). A review on advanced oxidation processes for the removal of taste and odor compounds from aqueous media. Water Res. 53:215-234.

Bláha L, Sabater S, Babica P, Vilalta E, Maršálek B (2004). Geosmin occurrence in riverine cyanobacetrial mats: is it causing a significant health hazard. Wat Sci Technol. 49:307-312.

Bruchet A, Duguet J, Suffe IM (2004). Role of oxidants and disinfectants on the removal, masking and generation of tastes and odours. Rev Environ Sci Biotechnol. 3:33-41.

Burgos L, Lehmann M, Simon D, de Andrade HHR, de Abreu BRR, Nabinger DD et al. (2014). Agents of earthy-musty taste and odor in water: evaluation of cytotoxicity, genotoxicity and toxicogenomics. Sci Tot Environ. 490:679-685.

Dionigi CP, Lawlor TE, McFarland JE, Johnsen PB (1993). Evaluation of geosmin and 2-methylisoborneol on the histidine dependence of TA98 and TA100 Salmonella Typhimurium tester strains. Water Res. 27:1615-1618.

Fotiou T, Triantis T, Kaloudis T, Hiskia A (2015). Evaluation of the photocatalytic activity of $\mathrm{TiO} 2$ based catalysts for the degradation and mineralization of cyanobacterial toxins and water off-odor compounds under UV-A, solar and visible light. Chem Eng J. 261:17-26.

Giglio S, Chou W, Ikeda H, Cane D, Monis P (2010). Biosynthesis of 2-methylisoborneol in cyanobacteria. Environ Sci Technol. 45:992-998.

Graham JL, Loftin KA, Meyer MT, Ziegler AC (2010). Cyanotoxin mixtures and taste-and-odor compounds in cyanobacterial blooms from the midwestern United States. Environ Sci Technol. 44:7361-7368.

Ho L, Hoefel D, Bock F, Saint CP, Newcombe G (2007). Biodegradation rates of 2-methylisoborneol (MIB) and geosmin through sand filters and in bioreactors. Chemosphere. 66:2210-2218.

Hochereau C, Bruchet A (2004). Design and application of a GC-SNIFF/MS system for solving taste and odour episodes in drinking water. Wat Sci Technol. 49:81-87.

Jiang J, Saint CP, Cane DE, Monis PT (2008) Isolation and characterization of the gene associated with geosmin production in cyanobacteria. Environ Sci Technol. 42:8027-8032.

Jüttner F (1984). Characterization of Microcystis strains by alkyl sulfides and $\beta$-cyclocitral. Zeitschrift für Naturforschung C 39:867-871.

Jüttner F, Watson SB (2007). Biochemical and ecological control of geosmin and 2-methylisoborneol in source waters. Appl Environ Microbiol. 73:4395-4406.

Kaloudis T, Triantis TM, Hiskia A (2017). Taste and odour compounds produced by cyanobacteria. In: Meriluoto J, Spoof L, Codd GA et al., editors: Handbook of Cyanobacterial Monitoring and Cyanotoxin Analysis. Chichester: John Wiley \& Sons:196-201.

Khiari D (2017). Managing cyanotoxins. Denver (CO): Water Research Foundation. $8 \mathrm{pp}$.

Komatsu M, Tsuda M, Ōmura S, Oikawa H, Ikeda H (2008). Identification and functional analysis of genes controlling biosynthesis of 2-methylisoborneol. Proc Natl Acad Sci USA. 105:7422-7427. 
Krishnani KK, Ravichandran P, Ayyappan S (2008). Microbially derived off-flavor from geosmin and 2-methylisoborneol: sources and remediation. Rev Environ Contam Toxicol. 194:1-27.

Newcombe G, Morrison J, Hepplewhite C, Knappe D (2002). Simultaneous adsorption of MIB and NOM onto activated carbon: II. Competitive effects. Carbon. 40:2147-2156.

Peter A, Von Gunten U (2007). Oxidation kinetics of selected taste and odor compounds during ozonation of drinking water. Environ Sci Technol. 41:626-631.

Qi M, Chen J, Sun X, Deng X, Niu Y, Xie P (2012). Development of models for predicting the predominant taste and odor compounds in Taihu Lake, China. PLoS One. 7:e51976.

Rice EW, Baird RB, Eaton AD, editors (2017). Standard methods for the examination of water and wastewater. Washington (DC): 23nd. American Public Health Association.

Smith JL, Boyer GL, Zimba PV (2008). A review of cyanobacterial odorous and bioactive metabolites: impacts and management alternatives in aquaculture. Aquaculture. 280:5-20.

Su M, Gaget V, Giglio S, Burch M, An W, Yang M (2013). Establishment of quantitative PCR methods for the quantification of geosmin-producing potential and Anabaena sp. in freshwater systems. Water Res. 47:3444-3454.

Suffet IM, Schweitze L, Khiari D (2004). Olfactory and chemical analysis of taste and odor episodes in drinking water supplies. Rev Environ Sci Biotechnol. 3:3-13.

Suurnäkki S, Gomez-Saez GV, Rantala-Ylinen A, Jokela J, Fewer DP, Sivonen K (2015). Identification of geosmin and 2-methylisoborneol in cyanobacteria and molecular detection methods for the producers of these compounds. Water Res. 68:56-66.

Watson SB (2004). Aquatic taste and odor: a primary signal of drinking-water integrity. J Toxicol Environ Health Part A. 67:1779-1795.

Young W, Horth H, Crane R, Ogden T, Arnott M (1996). Taste and odour threshold concentrations of potential potable water contaminants. Water Res. 30:331-340.

Zaitlin B, Watson SB (2006). Actinomycetes in relation to taste and odour in drinking water: Myths, tenets and truths. Water Res. 40:1741-1753.

Zuo Z (2019). Why algae release volatile organic compounds - the emission and roles. Front Microbiol. 10:491. 


\title{
2.10 UNSPECIFIED TOXICITY AND OTHER CYANOBACTERIAL METABOLITES
}

\author{
Andrew Humpage and Martin Welker
}

Early studies on toxic cyanobacteria largely reported effects of extracts of cyanobacteria, isolated strains or bloom material collected in the field on test systems such as animals and plants. With the purification of individual compounds that cause toxic effects and the elucidation of their structure, whole organisms were often replaced as test systems with cell lines, tissues or enzyme/substrate systems. The mode of action of a number of toxins could be revealed by these tests and eventually lead to a good understanding of the human health risks associated with these toxins.

However, in a number of studies, toxic effects on whole animals or in vitro test systems were found that could not be explained by the activity of known and quantifiable cyanobacterial toxins. It is therefore likely that cyanobacteria produce metabolites toxic to humans - as well as animals and plants in general - other than the ones described in sections 2.1-2.6.

This section therefore addresses two aspects of cyanobacterial toxicity beyond the known toxins: compounds produced by cyanobacteria that have shown bioactivity in various test systems and toxic effects of cyanobacterial extracts that cannot be attributed to the well-known compounds. Both aspects are tightly linked and may lead to the identification of further cyanotoxins in future.

\subsection{Bioactive metabolites produced by cyanobacteria}

The cyanotoxins described in sections $2.1-2.6$ are only a tiny part of the total diversity of secondary metabolites produced by cyanobacteria. Many of these compounds show bioactivity in organismic or in vitro test systems, making cyanobacteria a potentially interesting source of pharmacologically active substances (Burja et al., 2001; Chlipala et al., 2011; Welker et al., 2012; Vijayakumar \& Menakha, 2015). It is beyond the scope of this book to review the diversity of cyanobacterial metabolites and their biosynthesis (as far as it is known) and the reader is referred to available reviews (Welker \& von Döhren, 2006; Dittmann et al., 2015; Huang \& Zimba, 2019). In this context, it is worth to mention that heterologous expression of peptide or polyketide metabolites in cyanobacterial strains has become feasible (Videau et al., 2019; Vijay et al., 2019), potentially offering new opportunities for pharmacological research (Cassier-Chauvat et al., 2017; Stensjö et al., 2018). 
Most known metabolites, including the known cyanotoxins, are synthesised by three biosynthetic pathways or hybrids thereof: nonribosomal peptide synthetases (NRPS), polyketide synthases (PKS) or ribosomal synthesis of peptides that are modified post-translationally (Ziemert et al., 2008; Dittmann et al., 2015). These pathways allow the synthesis of virtually hundreds of structural variants of a single basic structure by variations in amino acid composition, modifications such as methylation or dehydration, and others, as has been well documented for microcystins (Catherine et al., 2017). Similar variability is known for several classes of nonribosomally synthesised peptides - for example, cyanopeptolins, aeruginosins and anabaenopeptins (Rounge et al., 2007; Ishida et al., 2009) - and ribosomally synthesised peptides such as microviridins (Philmus et al., 2008). The chemistry and biosynthesis of these peptides and that of the well-known cyanotoxins are very similar, suggesting that their role in contributing to the fitness of the producer organisms is also similar and the high toxicity of some molecules to humans (or mammals in general) is a mere coincidence. The latter point is also supported by the evidence that nonribosomal peptide synthesis by cyanobacteria and in particular, microcystin biosynthesis, is a very ancient trait, dating back to times long before mammals thrived on earth (Christiansen et al., 2001; Rantala et al., 2004). The comparison of gene clusters for biosynthetic pathways for peptide or polyketide synthesis, respectively, revealed a pattern of alternating regions with high conservation of variability between species (Cadel-Six et al., 2008; Ishida et al., 2009; Dittmann et al., 2015). This may indicate that some of the metabolite variability arises from horizontal gene transfer and recombination events (Sogge et al., 2013).

The production of particular metabolites is highly clone-specific, and clones within a population can be described as chemotypes. A high chemotype diversity has been reported for species of Microcystis, Planktothrix, Dolichospermum (Anabaena) and Lyngbya, for example (Welker et al., 2007; Rohrlack et al., 2008; Leikoski et al., 2010; Engene et al., 2011; Haruštiaková \& Welker, 2017; Le Manach et al., 2019; Tiam et al., 2019). Since individual cyanobacterial clones can produce multiple variants of multiple classes of metabolites, a multiclonal bloom of cyanobacteria can contain hundreds of bioactive metabolites (Welker et al., 2006; Rounge et al., 2010; Agha \& Quesada, 2014). This diversity makes it difficult to relate an observed toxic effect that cannot be explained by the activity of known (and quantifiable) cyanotoxins to a particular compound in a specific sample. Hence, the key challenges for a comprehensive risk assessment of cyanopeptides are their structural diversity, the lack of analytical standards and complex requirements for their identification and quantification (Janssen, 2019). 
For a number of individual cyanobacterial metabolites or groups of metabolites, bioactivity data are available. Toxicity to zooplankton (Daphnia) has, for example, been observed for microviridin J (Rohrlack et al., 2004), but no data are available for other organisms or other structural variants. Other frequently occurring peptides, such as cyanopeptolins or anabaenopeptins, have been shown to inhibit proteases of herbivorous zooplankton (Agrawal et al., 2005; Rohrlack et al., 2005; Czarnecki et al., 2006; Schwarzenberger et al., 2010). This indicates that synthesis of these peptides by cyanobacteria may confer a grazing protection for cyanobacterial populations (Savic et al., 2020). However, other compounds isolated from cyanobacteria have been variously described as cytotoxic, immune suppressant or cardioactive, or been shown to inhibit key mammalian enzymes such as acetylcholine esterase, chymotrypsin and trypsin (Humpage, 2008; Nagarajan et al., 2013). Thus, "offtarget" effects also appear to be quite common.

Another hypothesis links the production of diverse (peptide) metabolites to the defence of cyanobacteria against bacteria, phages and parasitic fungi (Gerphagnon et al., 2015). In particular for the latter, evidence has been presented that particular peptides can protect strains of Planktothrix from being infected by Chytridomycota (Sønstebø \& Rohrlack, 2011). The protection is apparently specific for the Planktothrix chemotype as well as for the infectious fungal strains (Rohrlack et al., 2013). This could explain the chemotype diversity and their wax and wane in populations of planktonic cyanobacteria with peptide diversity protecting populations from massive parasitic prevalence in a "Red Queen race" (Kyle et al., 2015). Protection from parasite infection may not be the only selective pressure triggering the high metabolic diversity of cyanobacteria, but surely is an interesting field, last but not the least, for the potential discovery of compounds of pharmacological interest, such as antifungal agents (Chlipala et al., 2011; Welker et al., 2012; Vijayakumar \& Menakha, 2015).

Although the structure of hundreds of cyanobacterial metabolites is known, the number of compounds not yet known may be equally high or even higher. This could explain the toxic effects of cyanobacterial extracts that are discussed in the following section.

\subsubsection{Toxicity of cyanobacteria beyond known cyanotoxins}

A number of researchers have reported toxic effects of cyanobacterial extracts that could not be explained by the compounds verifiably present in the extract. In addition, it has been noted that toxic effects of cyanobacteria that have been attributed to known cyanotoxins may actually have been caused by other toxic compounds (reviewed in Humpage (2008), with later examples included in Humpage (2008), Bernard et al. (2011), Froscio et al. (2011), and Humpage et al. (2012). Such unexplained effects include 
higher-than-expected acute toxicity in animal bioassays, effects on particular tissues or cell lines that are not observed using known cyanotoxins, and toxic effects which are not in agreement with established mechanisms attributed to known cyanotoxins (Falconer, 2007). For details of toxicity testing and possible pitfalls, see section 14.3.

To further complicate matters, many harmful effects described in human exposure events such as pneumonia and gastrointestinal symptoms, are not easily or solely explainable based on the described effects of cyanotoxins (Stewart et al., 2006). A cyanobacterial bloom provides an ideal habitat for concomitant growth of dependant bacteria, some of which may be pathogenic to humans (Chaturvedi et al., 2015).

From the observations on animals exposed to blooms in waterbodies or cyanobacterial culture material in laboratories, at the time of the publication of this book it appears likely that with the microcystins, cylindrospermopsins, neuro- and dermatotoxins described in sections $2.1-2.6$, the most potent and most frequently occurring cyanotoxins have been identified and their principle modes of action characterised. If these are absent or their concentrations are below their respective guideline values, major risks to human health from exposure to cyanobacteria therefore seem unlikely. However, the evidence discussed above also implies that any cyanobacterial bloom may contain further, yet unknown substances or microorganisms that may be hazardous to exposed water users. This is a further reason to avoid exposure to high concentrations of cyanobacterial biomass, regardless of its content of known cyanotoxins.

\section{REFERENCES}

Agha R, Quesada A (2014). Oligopeptides as biomarkers of cyanobacterial subpopulations. Toward an understanding of their biological role. Toxins. 6:1929-1950.

Agrawal MK, Zitt A, Bagchi D, Weckesser J, Bagchi SN, Von Elert E (2005). Characterization of proteases in guts of Daphnia magna and their inhibition by Microcystis aeruginosa PCC 7806. Environ Toxicol. 20:314-322.

Bernard C, Froscio S, Campbell R, Monis P, Humpage A, Fabbro L (2011). Novel toxic effects associated with a tropical Limnothrix/Geitlerinema-like cyanobacterium. Environ Toxicol. 26:260-270.

Burja AM, Banaigs B, Abou-Mansour E, Burgess JG, Wright PC (2001). Marine cyanobacteria-a prolific source of natural products. Tetrahedron. 57:9347-9377.

Cadel-Six S, Dauga C, Castets AM, Rippka R, Tandeau de Marsac N, Welker M (2008) Halogenase genes in two non-ribosomal peptide synthetase gene clusters of Microcystis (Cyanobacteria): sporadic distribution and evolution. Mol Biol Evol. 25:2031-2041.

Cassier-Chauvat C, Dive V, Chauvat F (2017). Cyanobacteria: photosynthetic factories combining biodiversity, radiation resistance, and genetics to facilitate drug discovery. Appl Microbiol Biotechnol. 101:1359-1364. 
Catherine A, Bernard C, Spoof L, Bruno M (2017). Microcystins and Nodularins. In: Meriluoto J, Spoof L, Codd GA et al., editors: Handbook of cyanobacterial monitoring and cyanotoxin analysis. Chichester: John Wiley \& Sons:109-126.

Chaturvedi P, Agrawal MK, Bagchi SN (2015). Microcystin-producing and nonproducing cyanobacterial blooms collected from the Central India harbor potentially pathogenic Vibrio cholerae. Ecotoxicol Environ Saf. 115:67-74.

Chlipala GE, Mo S, Orjala J (2011). Chemodiversity in freshwater and terrestrial cyanobacteria - a source for drug discovery. Curr Drug Targets. 12:1654-1673.

Christiansen G, Dittmann E, Ordorika LV, Rippka R, Herdman M, Börner T (2001). Nonribosomal peptide synthetase genes occur in most cyanobacterial genera as evidenced by their distribution in axenic strains of the PCC. Arch Microbiol. 178:452-458.

Czarnecki O, Lippert I, Henning M, Welker M (2006). Identification of peptide metabolites of Microcystis (Cyanobacteria) that inhibit trypsin-like activity in planktonic herbivorous Daphnia (Cladocera). Environ Microbiol. 8:77-87.

Dittmann E, Gugger M, Sivonen K, Fewer DP (2015). Natural product biosynthetic diversity and comparative genomics of the cyanobacteria. Trends Microbiol. 23:642-652.

Engene N, Choi H, Esquenazi E, Rottacker EC, Ellisman MH, Dorrestein PC et al. (2011). Underestimated biodiversity as a major explanation for the perceived rich secondary metabolite capacity of the cyanobacterial genus Lyngbya. Environ Microbiol. 13:1601-1610.

Falconer IR (2007). Cyanobacterial toxins present in Microcystis aeruginosa - More than microcystins! Toxicon. 50:585-588.

Froscio S, Sieburn K, Lau HM, Humpage A (2011). Novel cytotoxicity associated with Anabaena circinalis 131C. Toxicon. 58:689-692.

Gerphagnon M, Macarthur DJ, Latour D, Gachon CM, Van Ogtrop F, Gleason FH et al. (2015). Microbial players involved in the decline of filamentous and colonial cyanobacterial blooms with a focus on fungal parasitism. Environ Microbiol. 17:2573-2587.

Haruštiaková D, Welker M (2017). Chemotype diversity in Planktothrix rubescens (cyanobacteria) populations is correlated to lake depth. Environ Microbiol Rep. 9:158-168.

Huang I-S, Zimba PV (2019). Cyanobacterial bioactive metabolites - a review of their chemistry and biology. Harmful Algae. 68:139-209.

Humpage A, Falconer I, Bernard C, Froscio S, Fabbro L (2012). Toxicity of the cyanobacterium Limnothrix AC0243 to male Balb/c mice. Water Res. 46:1576-1583.

Humpage AR (2008). Toxin types, toxicokinetics and toxicodynamics. In: H.K. H, editors: Proceedings of the Interagency, International Symposium on Cyanobacterial Harmful Algal Blooms (ISOC_HAB): Cyanobacterial harmful algal blooms: State of the science and research needs. New York, USA: Springer:383-415.

Ishida K, Welker M, Christiansen G, Cadel-Six S, Bouchier C, Dittmann E et al. (2009). Plasticity and evolution of aeruginosin biosynthesis in cyanobacteria. Appl Environ Microbiol. 75:2017-2026.

Janssen EML (2019) Cyanobacterial peptides beyond microcystins-A review on cooccurrence, toxicity, and challenges for risk assessment. Water Res 151:488-499.

Kyle M, Haande S, Ostermaier V, Rohrlack T (2015). The red queen race between parasitic chytrids and their host, Planktothrix: A test using a time series reconstructed from sediment DNA. PLoS One. 10:e0118738. 
Le Manach S, Duval C, Marie A, Djediat C, Catherine A, Edery M et al. (2019). Global metabolomic characterizations of Microcystis spp. highlights clonal diversity in natural bloom-forming populations and expands metabolite structural diversity. Front Microbiol. 10:791.

Leikoski N, Fewer DP, Jokela J, Wahlsten M, Rouhiainen L, Sivonen K (2010). Highly diverse cyanobactins in strains of the genus Anabaena. Appl Environ Microbiol. 76:701-709.

Nagarajan M, Maruthanayagam V, Sundararaman M (2013). SAR analysis and bioactive potentials of freshwater and terrestrial cyanobacterial compounds: a review. J Appl Toxicol. 33:313-349.

Philmus B, Christiansen G, Yoshida WY, Hemscheidt TK (2008). Post-translational modification in microviridin biosynthesis. Chembiochem. 9:3066-3073.

Rantala A, Fewer D, Hisbergues M, Rouhiainen L, Vaitomaa J, Börner T et al. (2004). Phylogenetic evidence for the early evolution of microcystin synthesis. Proc Natl Acad Sci USA. 101:568-573.

Rohrlack T, Christiansen G, Kurmayer R (2013). Putative antiparasite defensive system involving ribosomal and nonribosomal oligopeptides in cyanobacteria of the genus Planktothrix. Appl Environ Microbiol. 79:2642-2647.

Rohrlack T, Christoffersen K, Friberg-Jensen U (2005). Frequency of inhibitors of daphnid trypsin in the widely distributed cyanobacterial genus Planktothrix. Environ Microbiol. 7:1667-1669.

Rohrlack T, Christoffersen K, Kaebernick M, Neilan BA (2004). Cyanobacterial protease inhibitor microviridin J causes a lethal molting disruption in Daphnia pulicaria. Appl Environ Microbiol. 70:5047-5050.

Rohrlack T, Edvardsen B, Skulberg R, Halstvedt CB, Utkilen HC, Ptacnik R et al. (2008). Oligopeptide chemotypes of the toxic freshwater cyanobacterium Planktothrix can form subpopulations with dissimilar ecological traits. Limnol Oceanogr. 53:1279-1293.

Rounge TB, Rohrlack T, Decenciere B, Edvardsen B, Kristensen T, Jakobsen KS (2010). Subpopulation differentiation associated with nonribosomal peptide synthetase gene cluster dynamics in the cyanobacterium Planktothrix spp. J Phycol. 46:645-652.

Rounge TB, Rohrlack T, Tooming-Klunderud A, Kristensen T, Jakobsen KS (2007). Comparison of cyanopeptolin genes in Planktothrix, Microcystis, and Anabaena strains: evidence for independent evolution within each genus. Appl Environ Microbiol. 73:7322-7330.

Savic GB, Bormans M, Edwards C, Lawton L, Briand E, Wiegand C (2020). Cross talk: two way allelopathic interactions between toxic Microcystis and Daphnia. Harmful Algae. 94:101803.

Schwarzenberger A, Zitt A, Kroth P, Mueller S, Von EE (2010). Gene expression and activity of digestive proteases in Daphnia: effects of cyanobacterial protease inhibitors. BMC Physiol. 10:6.

Sogge H, Rohrlack T, Rounge TB, Sonstebo JH, Tooming-Klunderud A, Kristensen T et al. (2013). Gene flow, recombination, and selection in cyanobacteria: population structure of geographically related Planktothrix freshwater strains. Appl Environ Microbiol. 79:508-515.

Sønstebø JH, Rohrlack T (2011). Possible implications of chytrid parasitism for population subdivision in freshwater cyanobacteria of the genus Planktothrix. Appl Environ Microbiol. 77:1344-1351. 
Stensjö K, Vavitsas K, Tyystjärvi T (2018). Harnessing transcription for bioproduction in cyanobacteria. Physiol Plant. 162:148-155.

Stewart I, Webb PM, Schluter PJ, Shaw GR (2006). Recreational and occupational field exposure to freshwater cyanobacteria-a review of anecdotal and case reports, epidemiological studies and the challenges for epidemiologic assessment. Environ Health. 5:6.

Tiam SK, Gugger M, Demay J, Le Manach S, Duval C, Bernard C et al. (2019). Insights into the diversity of secondary metabolites of Planktothrix using a biphasic approach combining global genomics and metabolomics. Toxins. 11:498.

Videau P, Wells KN, Singh AJ, Eiting J, Proteau PJ, Philmus B (2019). Expanding the natural products heterologous expression repertoire in the model cyanobacterium Anabaena sp. strain PCC 7120: production of pendolmycin and teleocidin B-4. ACS Synth Biol.

Vijay D, Akhtar MK, Hess WR (2019). Genetic and metabolic advances in the engineering of cyanobacteria. Curr Opin Biotechnol. 59:150-156.

Vijayakumar S, Menakha M (2015). Pharmaceutical applications of cyanobacteria A review. J Acute Med. 5:15-23.

Welker M, Dittmann E, von Döhren H (2012). Cyanobacteria as a source of natural products. In: Hopwood DA, editor: Natural product biosynthesis by microorganisms and plants, Part C. Methods in Enzymology. Amsterdam: Elsevier 517:23-46.

Welker M, Maršálek B, Šejnohová L, von Döhren H (2006). Detection and identification of oligopeptides in Microcystis (cyanobacteria) colonies: toward an understanding of metabolic diversity. Peptides. 27:2090-2103.

Welker M, Šejnohová L, von Döhren H, Nemethova D, Jarkovsky J, Maršálek B (2007) Seasonal shifts in chemotype composition of Microcystis sp. communities in the pelagial and the sediment of a shallow reservoir. Limnol Oceanogr. 52:609-619.

Welker M, von Döhren H (2006). Cyanobacterial peptides - Nature's own combinatorial biosynthesis. FEMS Microbiol Rev. 30:530-563.

Ziemert N, Ishida K, Liaimer A, Hertweck C, Dittmann E (2008). Ribosomal synthesis of tricyclic depsipeptides in bloom-forming cyanobacteria. Ang Chem Int Ed. 47:7756-7759. 